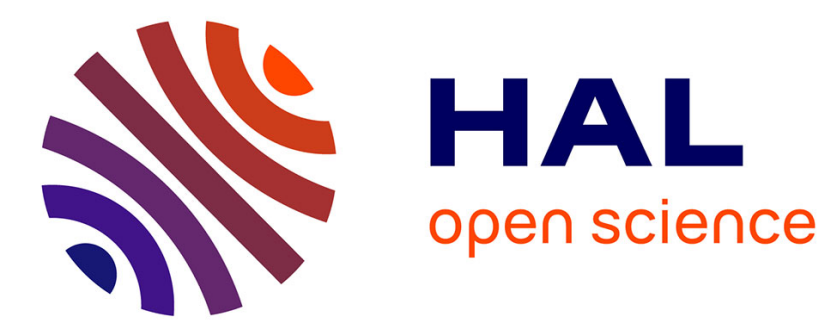

\title{
Taxonomy of Paleozoic radiolarian genera
}

Paula Noble, Jonathan C Aitchison, Taniel Danelian, Paulian Dumitrica, Jörg

Maletz, Noritoshi Suzuki, Jessie Cuvelier, Martial Caridroit, Luis O’Dogherty

\section{To cite this version:}

Paula Noble, Jonathan C Aitchison, Taniel Danelian, Paulian Dumitrica, Jörg Maletz, et al.. Taxonomy of Paleozoic radiolarian genera. Geodiversitas, 2017, 39 (3), pp.419-502. 10.5252/g2017n3a4 . hal-02487251

\section{HAL Id: hal-02487251 \\ https://hal.science/hal-02487251}

Submitted on 24 Feb 2020

HAL is a multi-disciplinary open access archive for the deposit and dissemination of scientific research documents, whether they are published or not. The documents may come from teaching and research institutions in France or abroad, or from public or private research centers.
L'archive ouverte pluridisciplinaire HAL, est destinée au dépôt et à la diffusion de documents scientifiques de niveau recherche, publiés ou non, émanant des établissements d'enseignement et de recherche français ou étrangers, des laboratoires publics ou privés. 


\section{Taxonomy of Paleozoic radiolarian genera}

Paula NOBLE

Department of Geological Sciences and Engineering, University of Nevada,

Reno, Nevada 89557-0138 (United States) and Univ. Lille, CNRS, UMR 8198 - Évo-Éco-Paléo, F-59000 Lille (France)

noblepj@unr.edu

Jonathan C. AITCHISON

School of Earth and Environmental Sciences, University of Queensland, St Lucia, Qld 4072 (Australia)

jona@uq.edu.au

Taniel DANELIAN

Univ. Lille, CNRS, UMR 8198 - Évo-Éco-Paléo, F-59000 Lille (France) taniel.danelian@univ-lille1.fr

Paulian DUMITRICA

Dennigkofenweg 33, CH-3073 Gümligen (Switzerland) paulian.dumitrica@unil.ch

Jörg MALETZ

Institut für Geologische Wissenschaften, Freie Universität Berlin, Haus C, Raum 005, 12249 Berlin (Germany) yorge@zedat.fu-berlin.de

Noritoshi SUZUKI

Department of Earth Science, Graduate School of Science, Tohoku University, 6-3 Aoba, Aramaki, Aoba-ku, Sendai 980-8578 (Japan) norinori@m.tohoku.ac.jp

Jessie CUVELIER

Univ. Lille, CNRS, UMR 8198 - Évo-Éco-Paléo, F-59000 Lille (France) jessie.cuvelier@univ-lille1.fr

Martial CARIDROIT

Univ. Lille, CNRS, UMR 8198 - Évo-Éco-Paléo, F-59000 Lille (France) martial.caridroit@univ-lille1.fr

Luis O'DOGHERTY

Facultad de Ciencias del Mar, Universidad de Cadiz, E-11510 Puerto Real (Spain)

luis.odogherty@uca.es

Published on 29 September 2017

urn:Isid:zoobank.org:pub:603CD230-5931-4506-A122-9CBC2F89189F

Noble P., Aitchison J. C., Danelian T., Dumitrica P., Maletz J., Suzuki N., Cuvelier J., Caridroit M. \& O’Dogherty L. 2017. Taxonomy of Paleozoic radiolarian genera, in Danelian T., Caridroit M., Noble P. \& Aitchison J. C. (eds), Catalogue of Paleozoic radiolarian genera. Geodiversitas 39 (3): 419-502. https://doi.org/10.5252/g2017n3a4 
KEY WORDS

Radiolarians,

taxonomy

Paleozoic, new synonyms.

MOTS CLÉS

Radiolaires,

taxonomie,

Paléozoïque, synonymes nouveaux.

\section{ABSTRACT}

This chapter is to be used as companion text with the companion chapter, an illustrated catalogue of Paleozoic radiolarian genera found in this volume, and serves the purpose of giving the reader explanation for any taxonomic operations undertaken during the course of constructing the catalogue. These operations refer to the status of the genera as valid, junior synonym, homonym, nomen nudum, nomen dubium, or not Radiolaria. We also include diagnoses and/or descriptions in the original language published, English translations where needed, and locality and age information for the type material.

\section{RÉSUMÉ}

Taxonomie des genres de radiolaires paléozoïques.

Cet article est un complément indispensable de la partie catalogue illustré des genres de radiolaires paléozoïques (article précédent) ; il a pour ambition de donner au lecteur toutes les informations taxonomiques nécessaires qui expliquent les changements introduits au cours de la construction du catalogue. Les statuts des genres, argumentés, sont fournis : valide, synonyme junior, homonyme, nomen nudum, nomen dubium, ou non radiolaire. De plus, il propose des traductions en Anglais des diagnoses ou définitions des genres publiées dans diverses langues et des informations sur la localité et l'âge du matériel type.

\section{INTRODUCTION}

This chapter provides explanatory text to the illustrated catalogue (Caridroit et al. 2017, this volume) and more detailed information for each genus, including remarks pertaining to their status, and the age and location of the type material for each type species of the valid genera. We also include the original diagnoses and/or descriptions of all genera in the language in which they were originally described (wherever possible), and an English translation, where necessary (or available). In cases where the current concept of the genus differs substantially from the original description, we attribute the sense of usage (i.e., sensu) to subsequent authorship. In the author attribution of each type species we provide the page number for the description of the type species and the plate and/ or figure numbers of all illustrations of the type species found in the original publication. The reader is referred to the taxonomy chapter 4 in De Wever et al. (2001) for illustrations and explanations of the terminology for the various taxa discussed for whom P. Dumitrica was the primary author, with contributions by $\mathrm{M}$. Caridroit and J. P. Caulet. In cases where we have adopted emended diagnoses from the literature, we include additional criteria and modifications under the remarks section. For genera whose status is not valid, we provide remarks to explain the decision. In many cases, generic names introduced in the literature have been synonymized. For those genera that are treated as a junior synonym, we provide explanatory remarks, including who arrived at that decision, and the basis for the decision. Likewise, we provide explanatory notes under the remarks for those taxa listed as nomina nuda and nomina dubia, and not Radiolaria.
Order ALBAILLELLARIA Deflandre, 1953

Family Albaillellidae Deflandre, 1953 sensu Holdsworth (1977)

Albaillellidae Deflandre, 1953: 407. — Holdsworth 1977: 168.

Spinodeflandrellidae Kozur, 1981: 267.

Albaillelloidea Afanasieva, 2000c: 123.

Albaillella Deflandre, 1952 sensu Won (1983)

Albaillella Deflandre, 1952: 873. - Won 1983: 123.

Spinodeflandrella Kozur, 1981: 267.

Imotoella Kozur \& Mostler, 1989: 163.

Saturnalbaillella Kozur \& Mostler, 1989: 162.

TYPE SPECIES. - Albaillella paradoxa Deflandre, 1952 (Deflandre 1952: 873, figs 1-5).

AgE AND LOCATION OF TYPE MATERIAL. - Visean (Lower Carboniferous), Montagne Noire, France.

TAXON CODE. -001.

STATUS. - Valid.

ORIGINAL DIAGNOSIS. - "La coque de l'organisme, en cône creux très allongé, est bâtie sur un squelette siliceux plein en forme d'H tronqué. Une branche majeure différenciée de ce squelette, peut atteindre l'apex, en formant une columelle détachée de la paroi de la coque à laquelle elle est reliée par un double système trabéculaire. Cette columelle peut disparaitre. La coque, également siliceuse, est brunâtre, mince, finement ponctulée, mais non perforée (à l'échelle 
du microscope optique). Son ouverture porte des épines obliques, toujours dirigées vers la branche majeure du squelette. Ces épines décèlent la symétrie bilatérale de la coque, qui paraît composée de bandes obliques sensiblement d'égale largeur." (Deflandre 1952: 873).

DiAGNOSIS (English translation). — “The organism's shell, a very elongate hollow cone, is built on a filled siliceous skeleton in the form of a truncated $\mathrm{H}$. A major rod, differentiated from this skeleton, may reach the apex to form a columnella detached from the wall of the shell to which it is connected by a double trabecular meshwork. This columnella may disappear. The shell is also siliceous, brownish, thin, finely punctate, but not perforated (as seen in transmitted light microscopy). Its aperture bears oblique spines, always oriented towards the major rod of the skeleton. These spines discern the bilateral symmetry of the shell, which appears to be composed of oblique bands of roughly approximately equal width."

\section{REMARKS}

Deflandre's diagnosis fits well with the lanceolate type species, $A$. paradoxa, Won's emendation (Won 1983) expands the Deflandre's diagnosis to include a wider array of shell morphologies, including species that are wider, and bear wings. Won also describes details of the lower part of the H-frame, the stapia, and notes the common occurrence of a line of pores along segments.

\section{Huasha Cheng, 1986}

Huasha Cheng, 1986: 71.

TYPE SPECIES. - Huasha holdsworthi Cheng, 1986 (Cheng 1986: 73, pl. 2, fig. 1, 10, 14, pl. 3, fig. 7).

Age AND location of TYPE MATERIAL. - Upper Devonian and Lower Carboniferous, Oklahoma and Arkansas, United States.

TAXON CODE. - 002 .

STATUS. — Junior synonym of Lapidopiscum (by Won 1998: 230).

DiagNOSIS. - “Test with closed triangular skeletal frame of intersector, $a$-, and $b$-rods. Four extra-triangular extensions developed only: i.d., i. v., b. d. and $b . v$. Perforate lamellar shell covering posterior $a$. $t$. and dorsal part of $i$. $t$. with large, circular basal aperture. Free, fully developed caveal ribs, three to six or more pairs in number, restricted to anterior portion of a.t.; C1 pair always rejoining the plane of proximal end of $b$. v. Strongly developed patagium surrounded the ventral side of the skeletal frame." (Cheng 1986: 71).

\section{REMARKS}

Huasha is considered a junior synonym to Lapidopiscum Deflandre 1958. Huasha was originally distinguished from Lapidopiscum by having a perforate lamellar shell rather than an imperforate one, by having well developed i.v. and b.v. extra-triangular extensions, and a longer shell (Won 1998). The difference in lamellar shell structure is a function of preservation and perception of the original authors. Examination of Lapidopiscum from the type material shows that there is no difference in the structure of the lamellar wall. Differences in the length of the extra-triangular extensions and of the shell as a whole are considered a species level distinction and does not warrant the designation of a new genus.
Imotoella Kozur \& Mostler, 1989

Imotoella Kozur \& Mostler, 1989: 163.

TYPE SPECIES. - Albaillella levis Ishiga, Kito \& Imoto, 1982 (Ishiga et al. 1982a: 17, pl. 3, figs 1-3).

Age and location of type Material. - Upper Permian of Japan.

TAXON CODE. - 003.

STATUS. - Junior synonym of Albaillella (by Dumitrica \& Caridroit in De Wever et al. 2001: 93).

DiAGNOSIs. - "Gehäuse konisch bis schlank-konisch, im apicalen Teil mehr oder weniger deutlich nach der Ventralseite umgebogen. Segmente bei der vermuteten Ausgangsform noch reifenförmig und stark hervortretend, bei den typischen Vertretern außen nur noch schwach oder gar nicht mehr erkennbar. Schale unperforiert, nur bei der vermuteten Ausgangsform mit einem Porenring im vorletzten Segment, der aber häufig auch sekundär verschlossen ist. Stets ist ein sehr kräftiger, etwas nach unten weisender Ventralflügel ausgebildet. Freie Columella in einem aussen bestachelten Ring verbunden. Kurze freie Trabekeln an der Innenseite der freien Columella sind vorhanden. Die übrigen Trabekeln sind fest in die Schale eingebaut und im Auflicht nicht zu erkennen." (Kozur \& Mostler 1989: 163).

DiAGNOSIS (English translation by J. P. Caulet RadWorld database modified by Jörg Maletz). — "Test conical to slender-conical with the apex curved more or less clearly towards the ventral side. In the supposed earlier representatives the segments are circular and very prominent, but in the typical representatives of the genus the segments are less pronounced, or cannot be observed at all on the outside. Shell imperforate, or in the supposed ancestors, with a row of pores on the penultimate segment, pores frequently, however, secondarily closed. Ventral wing always very strong, somewhat downwardly projecting. Free columellae linked to a ring with external spines. Short and free trabeculae located on the inner side of the free columellae. Other trabeculae strongly incorporated within the shell and not visible in reflected light."

\section{REMARKS}

Imotoella is considered a junior synonym to Albaillella Deflandre, 1952 . The type species, $A$. levis, clearly fits the diagnosis of Albaillella and should not be split from the remainder of the genus.

\section{Lapidopiscum Deflandre, 1958 sensu Holdsworth (1971)}

Lapidopiscum Deflandre, 1958: 2280. — Holdsworth 1971: 345. Huasha Cheng, 1986: 71.

TYPE SPECIES. — Lapidopiscum piveteaui Deflandre, 1958 (Deflandre 1958: 2278, fig. 2).

Age And location of type Material. - Visean (Lower Carboniferous), Cabrières, Hérault, Montagne Noire, France.

TAXON CODE. - 004 .

STATUS. - Valid.

ORIGINAL DIAGNOSIS. - "Coque siliceuse mince, en cloche asymétrique, à columnelles dorsale et ventrale prolongées hors de la coque en deux cones coalescents spongieux." (Deflandre 1958: 2280). 
DiAgnosis (English translation by J. P. Caulet RadWorld databasemodified by Taniel Danelian). - "Thin siliceous shell, in the shape of an asymmetrical bell, with ventral and dorsal comunellae that extend along the outside of the shell in two coalescing spongy cones".

\section{REMARKS}

Holdsworth (1971) and Won (1998) provide more detailed descriptions of this genus. Won (1998) notes that the test is a closed triangular skeletal frame of intersector, $a$-, and $b$-rods, with four extra-triangular extensions developed; i.d., b.d., i.v., and $b . v$, but that two ventral extensions (i.v. and b.v) may be obscured by spongy patagium (Won 1998). Lamellar shell covering is perforate (Won 1998) and bell-shaped (Deflandre 1958). Fully developed caveal ribs, three to four pairs observed in type species, originating on a.t. rod below b.d. extension (Holdsworth 1971). Well-developed patagium surrounding ventral side of the frame.

\section{Neoalbaillella Takemura \& Nakaseko, 1981}

Neoalbaillella Takemura \& Nakaseko, 1981: 210.

TYPE SPECIES. - Neoalbaillella ornithoformis Takemura \& Nakaseko, 1981 (Takemura \& Nakaseko 1981: 211, pl. 33, figs 1-6, text-fig. 2).

Age and location of type Material. - Upper Permian, Tamba Belt, Japan.

TAXON CODE. - 005 .

STATUS. - Valid.

DiAGNOSIS. - "Nearly bilaterally symmetrical, conical or subcylindrical shells of which the upper part is winged and imperforate and of which the lower part has windows. The lower part of the shell possessing trabeculae and windows arranged in transverse lines, but the upper part having an unknown internal structure. Apical cone bending in a bilaterally symmetrical plane. Two longitudinal rods with three or more spines lying at the dorsal and ventral sides of the lower shell part under the wings and protruding posteriorly from around the aperture." (Takemura \& Nakaseko 1981: 210).

\section{Protoalbaillella Cheng, 1986}

Protoalbaillella Cheng, 1986: 67.

TyPe SPECIES. - Protoalbaillella deflandrei Cheng, 1986 (Cheng 1986: 68, pl. 6, fig. 1, 3, 9, 11, 18).

Age And location of TYPE MATERIAL. - Westphalian (Pennsylvanian, Carboniferous), Upper Johns Valley Shale, Central Ouachita Mts., Oklahoma, USA.

TAXON CODE. - 006 .

STATUS. — Valid.

DiAGNOSIS. - "Albaillellinae having an imperforate, essentially dome- or cone-shaped lamellar shell, lacking crenulations; curved $a$-rod obliquely cutting across longitudinal axis of lamellar shell, with or without extra-rod extensions; curved b.t. and ventral i.t. forming h-frame with i.v. extension; h-frame with patagial tissue. Paired trabecular apophyses carried by dorsal, a-columella only." (Cheng 1986: 67).
Saturnalbaillella Kozur \& Mostler, 1989

Saturnalbaillella Kozur \& Mostler, 1989: 162.

TYPe SPECIES. - Albaillella cartalla Ormiston \& Lane, 1976 (Ormiston \& Lane 1976: 171, pl. 5, figs 9-15).

AgE AND LOCATION OF TYPE MATERIAL. — Lower Carboniferous, Oklahoma, USA.

TAXON CODE. - 007.

STATUS. — Junior synonym of Albaillella (by Dumitrica \& Caridroit in De Wever et al. 2001: 93).

DiAGNOSIS. - "Skelett unperforiert, meist aber in den Segmenten mit einem Ring von winzigen, außen oft (immer?) geschlossenen Poren (nur im Durchlicht erkennbar), gedrungen-bis spitz-konisch. Segmente im mittleren und distalen Teil des Gehäuses außen meist deutlich erkennbar. 2 stachelförmige Seitenflügel sind stets vorhanden, z.T. sind sie weit distalwärts verlagert, wobei dann apical noch ein weiterer kleiner Seitenstachel auftreten kann. Die freien Enden der dorsalen und ventralen Columella sind distal zu einem außen oft bestachelten Ring verbunden, innen weisen sie an einer Seite freie Trabekeln auf. Die übrigen Trabekeln sind in die Schale eingebaut, aber im Durchlicht meist kräftig gegen die Schale abgesetzt." (Kozur \& Mostler 1989: 162).

DiAGNOSIS (English translation by J. P. Caulet RadWorld database modified by Jörg Maletz). — " "Test thick set, or sharp conical, imperforate, except mostly on the segment bearing a ring which has very small pores, often (or always?) externally closed (they are visible only in transmitted light). Segments externally mostly well-marked in the median and distal parts of the test. Two spine-shaped lateral wings always present, sometimes distally displaced and with an additional smaller side spine. The free ends of the dorsal and ventral columellae are distally forming a ring with external spines, its inside bearing free trabeculae on one side. Other trabeculae incorporated in the shell, but appear to be strongly differentiated from the shell in transmitted light."

\section{REMARKS}

Saturnalbaillella was placed in synonymy with Albaillella by De Wever et al. (2001). Despite its short lamellar shell, the type species, $A$. cartalla fits within the morphologic parameters of Albaillella.

\section{Spinodeflandrella Kozur, 1981}

Spinodeflandrella Kozur, 1981: 267.

TyPe SPECIES. - Spinodeflandrella tetraspinosa Kozur, 1981 (Kozur 1981: 267, pl. 2, fig. 1).

Age and location of type Material. - Sakmarian, Lower Permian of the Cis-Urals, Russia.

TAXON CODE. - 008 .

STATUS. - Junior synonym of Albaillella (by Dumitrica \& Caridroit in De Wever et al. 2001: 93).

DiAGNOSIS. - "Wie für die Familie - Schale seitlich etwas abgeflacht, im schlanken apicalen Teil wenig, sonst kräftig segmentiert mit tiefen Einschnürungen zwischen den reifenförmigen Segmenten. Trotz der kräftigen Segmentierung ist kein aufgeblähter und abgesetzter 
Pseudothorax vorhanden. Schale im apicalen Teil unperforiert, distal mit einzelnen großen Poren. Von den beiden Columella gehen kräftige Bögen aus, die zunächst in die Schalenwand eingebaut sind, während sie im distalen Teil frei oder nur durch ein grobmaschiges Geflecht verbunden sind. Auf jeder Seite sitzen zwei kräftige Stacheln an." (Kozur 1981: 267).

DiAgNOSIS (English translation by J. P. Caulet - RadWorld database). - "As for the family (Family Spinodeflandrellidae Kozur 1981, our remark). Shell somewhat flattened laterally, vaguely segmented in the slender apical area and strongly differentiated into annular segments separated by deep strictures in the remaining part of the shell. Despite this strong segmentation, there is no clearly differentiated and inflated pseudothorax. Apical section of shell imperforate, distal part with isolated wide pores. Both columellae produce strong arches that are first included within the shell wall, but becoming free in the distal section, or are connected by a loose mesh. Two robust spines on each side."

\section{REMARKS}

Spinodeflandrella was placed in synonymy with Albaillella by De Wever et al. (2001) because its type species, the only species included in this genus and based on only the holotype, differs from Albaillella by morphologic characters (two additional spines) that seem to have just a species taxonomic value.

Family CERATOIKISCIDAE Holdsworth, 1969

Campanulithus Nazarov \& Rudenko, 1981

Campanulithus Nazarov \& Rudenko, 1981: 137.

TyPe SPECIES. - Campanulithus falcatus Nazarov \& Rudenko, 1981 (Nazarov \& Rudenko 1981: 137, pl. 1, figs 8-10).

Age And location of type material. — Upper Paleozoic, Southern Urals, Russia.

TAXON CODE. - 009 .

STATUS. - Valid.

DIAGNOSIS. - “Скелет счетырьмя длинными иглами, расходящимися из одной точки. ОАна из иг $б$ более крупная и Алинная, вследствие чего создается впечатление, что остальные иглы -как бы отходят от нее. Эта игла имеет две группировки из трехчетырех игл, иногда пересекающихся межАу собой (рисунок, ж).” (Nazarov \& Rudenko 1981: 137).

Diagnosis (English translation by J. P. Caulet RadWorld database). - "Skeleton with four long rods originating from a single point. One rod is much larger and longer, which gives the impression that the other rods originate from it. This rod has two groups of three to four spines sometimes linked altogether."

\section{Cangyuanella Feng \& Liu, 1993}

Cangyuanella Feng \& Liu, 1993b: 550; Feng 1992: 56 (nomen nudum).

TYPE SPECIES. - Cangyuanella deflandrei Feng, 1993 (Feng 1992: pl. 2, figs 21, 27 (nomen nudum); Feng \& Liu 1993b: 550, pl. 3, figs $18,19,26)$.

Age AND LOCATION OF TYPE MATERIAL. — Devonian, Yunnan, China.

TAXON CODE. -010 .
Status. - Junior synonym of Protoholoeciscus Aitchison, 1993 (herein).

DiAGNOSIS. - “壳体两侧对柯, 由一个近三角形骨架和外 壳组成. 外壳由三角形骨架上部支撑, 无孔, 侧视为四边形. 前(后)视近圆形; 前部发育三角形翼; 口为心形, 前宽后窄. 三角形骨架之b轴伸出, 下部构成双十字形架. $b$ 辅之下具发 育的网状骨片.” (Feng \& Liu 1993b: 550).

DiAgnosis (English translation courtesy of the Prof. Lanlan Zhang). "Bilateral symmetry, composed by a homothetic-triangular inner framework and an outer shell. The outer shell supported by the upper part of triangular framework. No pore on surface. Quadrilateral in side view. Suborbicular in both the front and back view. Triangular wing developed at the top. Aperture heart-shaped. Upper-part wide, bottom-part narrow. B-axis of the triangular inner framework extended out, formed a double cross in the bottom (of the triangular framework). Meshwork developed under the b-axis."

\section{REMARKS}

Original publication by Feng (1992) was a photograph without any description. Although the above description was later included in Feng \& Liu (1993b: 550) this work appeared in September 1993 and post-dated the May 1993 formal diagnosis of the genus Protoholoeciscus by Aitchison (1993a). Thus, Cangyuanella is regarded as the junior synonym of Protoholoeciscus.

\section{Ceratoikiscum Deflandre, 1953}

Ceratoikiscum Deflandre, 1953: 409.

Xiphachistrella Deflandre, 1973b: 499 (n. syn.)

TYPe SPECIES. - Ceratoikiscum avimexpectans Deflandre, 1953 (Deflandre 1953: 409, fig. 309A, B).

Age and location of type material. - Carboniferous, Montagne Noire, France.

TAXON CODE. -011

STATUS. - Valid.

DiAGNOSIS. - "Une enceinte grillagée, sorte de petite cage sphérique accrochée latéralement à un squelette assez complexe éventuellement rattachable à l'un des types de Plectoidae"(Deflandre 1953: 409).

Diagnosis (English translation by J. P. Caulet RadWorld database). - "[...] A lattice structure, kind of small spherical cage, laterally hooked to a rather complex skeleton that may be close to some of the Plectoidae forms [...]".

\section{Circulaforma Cheng, 1986}

Circulaforma Cheng, 1986: 87.

TyPe SPECIES. — Circulaforma delicata Cheng, 1986 (Cheng 1986: 87, pl. 4, figs 7, 8, 11, 15, 21).

Age AND location of TyPe MATERial. - Upper Carboniferous, Visean/Namurian, "Caney” Shale, Frontal Ouachitas, Oklahoma, USA.

TAXON CODE. - 012 .

STATUS. - Valid. 
DiAGNOSIS. - "Ceratoikiscidae with a ring-formed central skeletal frame; three main rods connect to ring; two of these rods are aligned and termed the dorsal and ventral rods, respectively; the third rod termed the subsidiary rod, is thinner, slightly curved, and located on the opposite side of strongly developed patagial tissues. Patagium well developed and moderately thick with varied numbers of spinules" (Cheng 1986: 87).

Durahelenifore Boundy-Sanders \& Murchey in Boundy-Sanders, Sandberg, Murchey \& Harris, 1999

Durahelenifore Boundy-Sanders \& Murchey in Boundy-Sanders, Sandberg, Murchey \& Harris, 1999: 64.

TYPESPECIES. - Durahelenifore robustum Boundy-Sanders \& Murchey in Boundy-Sanders, Sandberg, Murchey \& Harris, 1999 (BoundySanders et al. 1999: 66, pl. 1, figs A-G).

AgE AND LOCATION OF TYPE MATERIAL. - Upper Frasnian, Roberts Mountains, Nevada, USA.

TAXON CODE. -013 .

STATUS. - Junior synonym of Helenifore (by Wang et al. 2003: 128-129, 138).

DiAGNOSIS. - "The basic skeleton consists of a solid subcircular ring with two long $\mathrm{i}$-spines extending from the ring about 180 degrees apart" (Boundy-Sanders \& Murchey in Boundy-Sanders et al. 1999: 64).

\section{Eoalbaillella Feng \& Liu, 1992}

Eoalbaillella Feng \& Liu, 1992: 550; 1993a: 244.

Paraholoeciscus Aitchison, 1993a: 363.

TyPe SPECIES. - Eoalbaillella lilaensis Feng \& Liu, 1992 (Feng \& Liu 1992: 551, pl. 1, figs 1-16 [in Chinese]; Feng \& Liu 1993a: 244, pl. 1, fig. 1 [English translation]).

AgE AND LOCATION Of TYPE MATERIAL. - Lower Devonian, Western Yunnan, China.

TAXON CODE. -014

STATUS. — Valid.

DiAGNOSIS. 一 “壳体两侧对称, 由一个三角形骨架和外壳组 成. 外壳由三角形骨架支撑, 无孔, 锥形或近柱形, 开口部有 许多口刺. 三角形骨架由 $a$ 轴, b 轴和 $\mathrm{i}$ 轴组成, $a$ 轴较 $\mathrm{i}$ 和 $\mathrm{b}$ 轴短, $\mathrm{i}$ 和 $\mathrm{b}$ 轴上部及 $\mathrm{a}$ 轴被外壳覆盖, $\mathrm{i}$ 和. $\mathrm{b}$ 轴下部裸露, 相交形成 $\mathrm{X}$ 形.” (Feng \& Liu 1992: 550).

DiAgNOSIS (English translation). - "The test bilaterally symmetrical, composed of a lamellar shell and a triangular framework. The lamellar shell, supported by the triangular framework, imperforate, subcylindrical or conical, having numerous marginal spines around apertural margin. A-rod much shorter than i, brod forming an elongate triangular framework, a-rod and upper parts of i, b-rod covered by the shell; the lower parts of i, b-rod, without shell, like the shape of the letter X." (translation of the original Chinese language description of Feng \& Liu [1992: 550] in Feng \& Liu [1993a: 244]).
Gansuceratoikiscum Wang, Cheng \& Zhang, 2010

Gansuceratoikiscum Wang, Cheng \& Zhang, 2010: 48.

TYPE SPECIES. - Gansuceratoikiscum guanzhuangensis Wang, Cheng \& Zhang, 2010 (Wang et al. 2010: 473, pl. 1, fig. 11).

AgE AND LOCATION OF TYPE MATERIAL. — Sandbian, Upper Ordovician, Pingliang Formation, Gansu Province, China.

TAXON CODE. -015 .

STATUS. - Valid.

DIAGNOSIS. - "Six rod-like primary spines positioned in eccentric place. The pairs of caveal ribs are paired on the dorsal rod of the a-rod; The patagial tissue is present on one lateral side of the $\mathrm{i}$-rod. A single row of arches (or by-spines) connect the primary spines, forming a simple cortical shell."(Wang et al. 2010: 48).

\section{REMARKS}

This genus differs from Protoceratoikiscum in that it has a framework composed of 6 rods connecting to a median bar. Ceratoikisum has 3 rods ( $\mathrm{a}, \mathrm{b}$, intersector) that cross to form a triangle. It differs from Protoceratoikiscum in that it possesses row of arches that connect the primary rods to form a subcircular shell, and the rods join in an eccentric position in Gansuceratoikiscum.

\section{Glanta Wakamatsu, Sugiyama \& Furutani, 1990 sensu Umeda (1998)}

Glanta Wakamatsu, Sugiyama \& Furutani, 1990: 180. — Umeda 1998: 98.

TYPE SPECIES. - Glanta fragilis Wakamatsu, Sugiyama \& Furutani, 1990 (Wakamatsu et al. 1990: 181, pl. 12, figs 1-7)

AgE AND LOCATION OF TYPE MATERIAL. - Tlecerina-Glanta assemblage, Middle Devonian, Kurosegawa tectonic zone, southwest Japan.

TAXON CODE. - 016 .

STATUS. — Valid.

ORIGINAL DIAGNOSIS. - "Ceratoikiscidae with bilaterally symmetric shell. Central skeletal frame triangular with five to six extratriangular rods. Shell perforate or imperforate, covering a.t. and the dorsal portion of i.t., supported by many trabeculae arising from a.t. and the dorsal portion of $i$.t. Aperture of the shell facing to the ventral portion of b.t. Single pair of free-developed caveal ribs originating from $a-/ b$ - junction, projecting almost perpendicularly to the central skeletal plane."(Wakamatsu et al. 1990: 180).

\section{REMARKS}

Umeda (1998) emends the diagnosis to indicate that the lamellar shell is always perforate.

\section{Helenifore Nazarov \& Ormiston, 1983 sensu Noble \& Lenz (2007)}

Helenifore Nazarov \& Ormiston, 1983a: 464. — Noble \& Lenz 2007: 1046 
Nazaromistonella Furutani, 1990: 52.

Durahelenifore Boundy-Sanders \& Murchey in Boundy-Sanders, Sandberg, Murchey \& Harris, 1999: 64.

TyPE SPECIES. - Helenifore laticlavium Nazarov \& Ormiston, 1983 (Nazarov \& Ormiston 1983a: 464, pl. 2, figs 8, 11, 13, 14).

Age AND LocATION OF TYPE MATERIAL. - Frasnian (Upper Devonian), Gogo Formation, Western Australia.

TAXON CODE. -017 .

STATUS. - Valid.

DiAGNOSIS. - "The basic skeleton consists of two intersecting spines, which join a slightly elongate ring of platy fabric with a circular central opening. The spines continue through the outer wall of the ring; one is larger than the other." Nazarov \& Ormiston 1983a: 464).

\section{REMARKS}

Noble \& Lenz (2007) describe a single intersector spine that joins an elongate ring, and may be covered with either platy fabric or patagium.

\section{Holoeciscus Foreman, 1963 sensu Schwartzapfel \& Holdsworth (1996)}

Holoeciscus Foreman, 1963: 294. — Schwartzapfel \& Holdsworth 1996: 125.

TYPe SPECIES. - Holoeciscus auceps Foreman, 1963 (Foreman 1963: 294, pl. 8, fig. 8a, b, pl. 9, fig. 1, text-fig. 6-8).

Age and location of TyPe MATERIAL. - Upper Devonian, Huron Member, Ohio Shale, USA.

TAXON CODE. -018 .

STATUS. — Valid

DiAGNOSIS. - "The side of the triangle formed by the a-spine is much shorter than the sides formed by the b-spine and intersector. The caveal ribs are joined laterally to form a lamellar wall." (Foreman 1963: 294).

\section{REMARKS}

The emended diagnosis by Schwartzapfel \& Holdsworth (1996: 125) elaborates on additional characters, including subrectangular to subtrapezoidal shape of the lamellar shell and small size of extratriangular extensions.

\section{Kappaforma Noble \& Lenz, 2007}

Kappaforma Noble \& Lenz, 2007: 1050.

Type SPECIES. - Kappaforma insecta Noble \& Lenz, 2007 (Noble \& Lenz 2007: 1052, figs 6.8, 6.9, 8.5-8.9).

Age AND LOCATION OF TYPE MATERial. - Upper Wenlock (Silurian), Cape Phillips Formation, Arctic Canada.

TAXON CODE. - 019 .

STATUS. - Valid.
DiAGNOSIs. - "Basic frame consisting of three rods $\left(\mathrm{k}_{\mathrm{v}}-\mathrm{k}_{\mathrm{d}}, \mathrm{k}_{\mathrm{a}}\right.$, and $c_{v}$ ) in same plane arranged crudely in shape of letter " $k$." Longest rod straight and composed of two parts, dorsal half $\left(\mathrm{k}_{\mathrm{d}}\right)$ bearing caveal ribs, and ventral half $\left(\mathrm{k}_{\mathrm{v}}\right)$ partially covered in patagium. Patagium forms incomplete ring attaching along dorsal half of $\mathrm{k}_{\mathrm{v}}$ to $\mathrm{k}_{\mathrm{a}}$ rod" (Noble \& Lenz 2007: 1050).

\section{Nazaromistonella Furutani, 1990}

Nazaromistonella Furutani, 1990: 52.

TYPE SPECIES. - Nazaromistonella speciosus Furutani, 1990 (Furutani 1990: 53, pl. 12, figs 5-7).

Age and location of type material. - mid Paleozoic Fusalfanus osobudaniensis assemblage, Osubudani Valley, Fukuji area, Honshu Japan.

TAXON CODE. -020 .

STATUS. - Junior synonym of Helenifore Nazarov \& Ormiston, 1983 (by Aitchison et al. 1996: 59).

DiAGNOSIS. - "Bilaterally symmetrical skeleton consists of a-rod, b-rod, intersector, caveal ribs or vanes, and a branch arising from b.v. A somewhat ellipsoidal ring is made by the following five parts; a.t., b.t., proximal part of b.v., a branch arising from b.v., and proximal part of a.p. Intersector is nearly straight and penetrates the ring. i.d., i.v., a.a., distal part of b.v., and distal part of a.p. project from the ring. B.d. is absent. Caveal ribs or vanes arise mainly from a.t. but also from the base of a.p. Caveal ribs or vanes elongate parallel to the ring." (Furutani 1990: 52).

\section{REMARKS}

Furutani's description of Nazaromistonella overlaps with the diagnosis for Helenifore. Noble \& Lenz (2007) standardized the terminology between Helenifore and Nazaromistonella, revealing the shared skeletal framework. The species Nazaromistonella speciosus Furutani, 1990 was revised as Helenifore speciosus in Aitchison et al. (1996: 59). They also regarded Helenifore speciosus as a senior synonym of Helenifore fasciola Nazarov \& Ormiston, 1993 - as Nazaromistonella was a monospecific genus, synonymizing of the type species with Helenifore synonymizes the genus by default. This is followed by Dumitrica in De Wever et al. (2001).

\section{Nazarovites Afanasieva, 2000}

Nazarovites Afanasieva, 2000a: 360.

TYPE SPECIES. - Nazarovites bioculus Afanasieva, 2000 (Afanasieva 2000a: 364, pl. 1, fig. 4-5).

Age AND LOCATION Of TYPe MATERIAL. - Frasnian, Upper Devonian, the Lyaiol River, outcrop 1904, Timan-Pechora Province, Russia.

TAXON CODE. - 021.

STATUS. - Valid .

DiAGNOSIS. - "Skeleton formed by three main rod- shaped spines radiating from a central point at an angle of $90^{\circ}$ with respect to each other: anteroposterior $(v L)$, transverse $(g L)$, and median $(m L)$ spines. Apical part of anteroposterior spine includes arched by-spines (I), located at one or two levels. Differently arched by- spines may form ring-shaped structures."(Afanasieva 2000a: 360). 


\section{Neoholoeciscus Ormiston \& Lane, 1976}

Neoholoeciscus Ormiston \& Lane, 1976: 173.

Type SPECIES. - Neoholoeciscus cancermimus Ormiston \& Lane, 1976 (Ormiston \& Lane 1976: 174, pl. 5, figs 5-8, text-fig. 4).

AgE AND LOCATION Of TYPE MATERIAL. - Mississippian, Sycamore Limestone, Arbuckle Mountains, Oklahoma, USA.

TAXON CODE. - 022

STATUS. — Valid.

DiAGNOSIS. - "Enclosed cavea internally supported by triangular ceratoikiscid frame elongated along the a-road, cavea is subrectangular in lateral view. Wall consists of at least seven pairs of caveal ribs sheathed by an imperforate lamella. Free ends of the frame spines emerge at the four angles of the shell." (Ormiston \& Lane 1976: 173).

\section{Paraholoeciscus Aitchison, 1993}

Paraholoeciscus Aitchison, 1993a: 363.

TYPE SPECIES. - Paraholoeciscus bingaraensis Aitchison, 1993 (Aitchison 1993a: 363, pl. 1, fig. 5).

Age And location of TYPE Material. - Devonian, Djungati terrane, New England Orogen, eastern Australia.

TAXON CODE. -023 .

STATUS. - Junior synonym of Eoalbaillella Feng \& Liu, 1992 (by Wang et al. 2003: 140).

DiAGNOSIs. - "Triangular frame with a.t. the shortest rod and b.t. and i.t. subequal in length. A.t. curves towards b.t. Lamellar shell rectangular to trapezoidal in lateral view, covering $a$.t. and dorsal two thirds of both i.t. and b.t. rods with a large, circular basal aperture pointing towards $b$ - $i$ - junction point. Several pairs of caveal ribs, obliquely arranged, indistinct but traceable along the surface of the lamellar shell. Lamellar shell rarely with small pores developed on it. Marginal spines around apetural margin. V-shaped intersection between b.t. and i.t. rods which diverge at approximately $50^{\circ}$ beyond the $b$ - $i$ - junction." (Aitchison 1993a: 363).

\section{REMARKS}

Paraholoeciscus was described by Aitchison in May 1993 whereas Feng \& Lui described Eoalbaillella in Chinese in 1992, with an English translation published in February 1993.

\section{Proholoeciscus Li, 1995}

Proholoeciscus Li, 1995: 338.

TyPe SPECIES. - Proholoeciscus foremanii Li, 1995 (Li 1995: 339, pl. 2, fig. 9).

Age And location of type material. - Middle Ordovician, Darriwilian, Baijingsi, Qilian Mountains, China.

TAXON CODE. -024 .

STATUS. — Nomen dubium (herein).
DiAGNOSIS. — "Test consists of a-rod, b-rod, i-rod and four-five pair ribs, they forming a sample skeleton, all of rod is undeveloped, it is incomplete, without any lamellar shell” (Li 1995: 338).

\section{REMARKS}

The specimens of the type species are noticeably incomplete and indistinguishable from broken specimens of Ceratoikiscum.

\section{Protoceratoikiscum Goto, Umeda \& Ishiga, 1992}

Protoceratoikiscum Goto, Umeda \& Ishiga, 1992: 165.

TYPE SPECIES. - Protoceratoikiscum chinocrystallum Goto, Umeda \& Ishiga, 1992 (Goto et al. 1992: 166, pl. 17, figs 1-3).

Age and location of TYPE MATERIAL. - Upper Ordovician, Lachlan Fold Belt, southeastern Australia.

TAXON CODE. - 025 .

STATUS. - Valid.

DiAGNOSIS. - "Seven rod like spines are radiating from the central part of the shell in horizontal plane, and two of these curve distally with clockwise rotation. In this attitude, spines being numbered from first to seventh, two spines (first or top and fourth or bottom spines) are nearly straight and sitting opposite site, and form intersector or main spine. Third and seventh spines extending both sides of main spines, distally curved. Second spine is sitting on right side and fifth and sixth spines sitting left side. By spines connect these spines and form 'spider web' like shell." (Goto et al. 1992: 165).

\section{Protoholoeciscus Aitchison, 1993}

Protoholoeciscus Aitchison, 1993a: 362.

Cangyuanella Feng \& Liu, 1993b: 550 (n. syn.)

TYPe SPECIES. - Protoholoeciscus hindea Aitchison, 1993 (Aitchison 1993a: 362, pl. 1, fig. 3).

Age and location of type Material. - Upper Devonian, Woolomin Group, Djungati terrane, upper Barnard valley, eastern NSW, Australia.

TAXON CODE. -026 .

STATUS. - Valid.

DiAgNOSIS. - "Test as with family. Triangular frame with a.t. the shortest rod. B.t. and i.t. subequal in length. Lamellar shell rectangular to trapezoidal in lateral view, covering a.t. and dorsal parts of both i.t. and b.t. rods. Large, oblate basal aperture pointing towards $i$ - $t$ - rod. Spines around apetural margin. Five thorn-shaped rod extensions (b.v., b.d., i. v. i.d. and a.p.). A.p ventrally offset along i.t" (Aitchison 1993a: 362).

\section{Raphidociclicus Nazarov \& Rudenko, 1981}

Raphidociclicus Nazarov \& Rudenko, 1981: 135.

TYPe SPECIES. — Raphidociclicus hiulcus Nazarov \& Rudenko, 1981 (Nazarov \& Rudenko 1981: 135, pl. 1, fig. 1). 
AgE AND LOCATION OF TYPE MATERIAL. — Upper Carboniferous Lower Permian, South Urals, Russia.

TAXON CODE. -027 .

STATUS. - Valid.

DiAGNOSIS. - “Характерна хорошо развитая игла "b” и слабо выраженные иглы “а” и “i” (рисунок, б). Все иглы соединены массивным кольцом (ребро $\mathrm{C}_{1}$ ), от которого отходят парные апофизы. Все скеметные элементы соединены сетчатой ими губчатой тканью, развитой неравномерно. Соединение патагия с иглами образует небольшие розетки, или такое соединение имеет виА Авух Аистов полуоткрытой книги (рисунок, г).” (Nazarov \& Rudenko 1981: 135).

Diagnosis (English translation by J. P. Caulet RadWorld database). - 'Well differentiated 'b' rod and less important 'a' and 'i' rods (following terminology of Holdsworth 1969: 233). All rods linked into a robust ring (rib C1) from which originate pairs of apophyses. All skeletal elements are united in a irregularly organized latticed or spongy plate. Patagium and rods define small rosettes and their junction looks like the two pages of a half open book."

\section{Xiphachistrella Deflandre, 1973}

Xiphachistrella Deflandre, 1973b: 499; 1960: pl. 1, fig. 25 (nomen nudum).

TYPe SPECIES. - Xiphachistrella acipensis Deflandre, 1973 (Deflandre 1960: pl. I, fig. 25 [nomen nudum]), described in Deflandre (1973a: 292, pl. 4, fig. 4-7x).

AgE AND LOCATION OF TYPE MATERIAL. — Lower Carboniferous, France.

TAXON CODE. -028 .

STATUS. — Junior synonym of Ceratoikiscum Deflandre, 1953 (herein).

DiagNOSIS. - “Squelette muni d'un gros spicule droit, tricostulé dans sa partie supérieure qui est en forme de poignard et se rétrécit brusquement en un point d'où partent des arcs régulièrement courbés, assez larges, un peu plus petits que des quarts de cercles et se terminant en donnant naissance à une forte épine perpendiculaire et dirigée vers le haut; à ces formations se joignent d'autres arcs, minces, dirigés vers la partie inférieure et pouvant la rejoindre, arcs très partiellement conservés. Partie médiane du spicule axial oblitérée et non-descriptible. Partie inférieure portant quatre cornes divergentes, droites, pointues, formant un angle d'environ $65^{\circ}$, reliées entre elles par de très fines trabécules transversales plus ou moins obliques." (Deflandre 1973b: 499).

DiAgnOsis (English translation by Taniel Danelian). — "Skeleton bearing a large straight spicule, tricostulate in its upper part which has the form of a dagger and suddenly shrinks to a point from which regularly curved wide arches a little less than complete circles and quarters end giving rise to a strong upwards directed perpendicular spine; these join other arches, slender, directed to the bottom which may join, partially preserved arches. Mid-section of the axial spike is obliterated and not describable. Lower part with four diverging horns, straight, pointed, forming an angle of about $65^{\circ}$, connected by very fine, more or less oblique transverse trabeculae."

\section{REMARKS}

Re-examination of slides BD54, R45/3 and BD 82, G37/4 of Deflandre's collection by Martial Caridroit indicates that Xiphachistrella acipiens is a junior synonym of Ceratoikiscum because both share the characteristic initial triangle. Note also that the type species is described in Deflandre (1973a: 292) but Deflandre's genus description appears later (Deflandre 1973b: 499).

\section{Family FollicuCUllidAe Ormiston \& Babcock, 1979}

Cariver Kozur, 1993

Cariver Kozur, 1993: 108.

TyPe SPECIES. - Follicucullus orthogonus Caridroit \& De Wever, 1984 (Caridroit \& De Wever 1984: 642, pl. 1, figs 23-29).

Age and location of type material. - Upper Permian, Kamigori, Japan.

TAXON CODE. - 029 .

STATUS. - Junior synonym of Follicucullus (by Takemura et al. 1999: 758).

DiAgNosis. - "Apical horn long, unsegmented. Pseudothorax large, inflated. Pseudoabdomen, partly also posterior part of pseudothorax ventralwards curved. Aperture oval, situated on the ventral side, perpendicularly or nearly perpendicularly to the test axis. A ventral sinus on the pseudothorax is always present, a dorsal sinus may be additionally present." (Kozur 1993: 108).

\section{REMARKS}

Cariver is considered a junior synonym of Follicucullus because the type species falls well within the original diagnosis of Follicucullus. Kozur (1993) mentions that there are some species that appear transitional between Cariver and the narrower definition of Follicucullus sensu Kozur \& Mostler (1989), such as Follicucullus? charveti Caridroit \& De Wever, 1984, which supports our opinion that the distinction between these genera is not a clear one and the differences between them should be considered at species level.

\section{Curvalbaillella Kozur \& Mostler, 1989}

Curvalbaillella Kozur \& Mostler, 1989: 179.

TYPE SPECIES. - Pseudoalbaillella U-forma Holdsworth \& Jones, 1980 (Holdsworth \& Jones 1980: 285, app. fig. 1C, F).

Age and location of type material. - Lower Permian, CisUrals, Russia.

TAXON CODE. - 030 .

STATUS. - Junior synonym of Parafollicucullus (by Dumitrica \& Caridroit in De Wever et al. 2001: 93).

DiAGNOSIS. — "Gehäuse dreigeteilt, unperforiert. Apicalkegel spitzkonisch, unsegmentiert, z.T. schwach segmentiert. Pseudothorax klein, wenig bis mäßig aufgebläht, schwach bis deutlich gegen den Apicalkegel und das Pseudoabdomen abgesetzt. Pseudoabdomen lang bis sehr lang, schlank, unsegmentiert, distal vollständig umgebogen, wobei der rückgebogene Abschnitt meist nur kurz ist, gelegentlich aber auch sehr lang werden kann und dann parallel zur Hauptachse so weit nach vorn reichen kann wie die Spitze des Apicalkegels. Die 
Columella laufen apical zusammen und sind distal frei, wobei die freien Columella stets nach vorn oder schräg nach vorn gerichtet sind. Dorsale freie Columella mäßig lang, mit einem sehr großen Stachel an der Außenseite, wo noch weitere 1-2 kleine Stacheln auftreten können. Ventrale freie Columella kürzer, mit 0-1 kurzem Stachel an der Außenseite. Trabekeln völlig in die Schale eingebaut, nur im Durchlicht erkennbar. Freie Trabekeln treten bei adulten Formen nicht auf. Apertur groß, nach vorn oder etwas schräg nach vorn gerichtet, rund bis oval oder spitz-oval.” (Kozur \& Mostler 1989: 179).

DiAGNOSIS (English translation by J. P. Caulet RadWorld databasemodified by Jörg Maletz). — "Test three-segmented, imperforate. Apex sharply conical, unsegmented, partially weakly segmented. Pseudothorax small, slightly to moderately inflated, weakly to clearly distinguished from the apex and the pseudoabdomen. Pseudoabdomen long to very long, slender, not segmented, entirely recurved at its distal end, where the dorsally curved section is mostly short, but occasionally very long and then parallel to the main axis, reaching the tip of the apex of the shell. Columellae come together apically and are free distally, the ends are always straight or obliquely directed to the front part. Free dorsal columella moderately long with a very large spine on its external side, where 1-2 secondary small spines may be located. Free ventral columella shorter, with $0-1$ short spines on its external side. Trabeculae inserted in the shell, only visible in transmitted light. No free trabeculae in adult specimens. Aperture large, directed straight or obliquely ahead, circular to oval, or sharply oval."

\section{REMARKS}

This genus is synonymized with Pseudoalbaillella in De Wever et al. (2001: 93) on the basis of having both a winged pseudothorax. Parafollicucullus is considered a senior synonym to Pseudoalbaillella and by extension to Curvalbaillella.

\section{Follicucullus Ormiston \& Babcock, 1979}

Follicucullus Ormiston \& Babcock, 1979: 332.

Cariver Kozur, 1993: 108.

TYPE SPECIES. - Follicucullus ventricosus Ormiston \& Babcock, 1979 (Ormiston \& Babcock 1979: 332, pl. 1, figs 6-14).

Age And location of type MATERial. — Guadalupian (Permian), Lamar Limestone, Delaware Basin, USA.

TAXON CODE. - 031 .

STATUS. - Valid.

DiAgNOSIS. - "Shell imperforate, apical portion conical, beneath which is a weakly inflated to subspherical region sharply demarked from skirt-like expansion of apertural region. Aperture elliptical, partly closed by flap, which is prolonged into a long spine. A second shorter spine paralleling the first extends from the opposite edge of the aperture. Both spines oblique to the axis of shell. Internally, a pair of longitudinal ribs occupies the apical portion and joins beneath the apex of the shell." (Ormiston \& Babcock 1979: 332).

\section{Foremanconus Kozur \& Mostler, 1989}

Foremanconus Kozur \& Mostler, 1989: 180.

TYPe SPECIES. - Parafollicucullus sakmarensis Kozur, 1981 (Kozur 1981: 266, pl. 1, figs 1, 3).
Age and location of type Material. - Sakmarian, Lower Permian, Cis-Urals, Russia.

TAXON CODE. - 032 .

STATUS. - Junior synonym of Parafollicucullus (by Dumitrica Caridroit in De Wever et al. 2001: 93).

DiAGNOSIS. — "Gehäuse deutlich dreigeteilt, unperforiert. Apicalkegel deutlich segmentiert oder unsegmentiert. Pseudothorax groß, stark aufgebläht, sphärisch bis unsphärisch. Er weist 2 Seitenstacheln auf. Der ventrale Seitenstachel ist sehr groß, etwas nach unten geneigt. Seine obere Kante ist mehr oder weniger deutlich gezähnelt. Pseudoabdomen lang, mit 3 Segmenten, von denen das distale kräftig ventralwärts umgebogen, aber nicht oder nur wenig rückgebogen ist Dadurch liegt die herzförmige Apertur in seitlicher Position an der Ventralseite, oder sie ist ein wenig schräg nach vorn gerichtet. Die Columella laufen apical zusammen und sind distal frei. Die freien Columella sind entweder etwa senkrecht zur Längsachse des Gehäuses ventralwärts gerichtet oder etwas schräg nach vorn gerichtet. Die dorsale freie Columella ist mäßig lang und weist außen 3-4 Stacheln auf, von denen aber nur einer groß ist. Die ventrale Columella ist kurz und unbestachelt oder weist nur einen winzigen Stachel auf. Die Trabekeln sind alle in die Schale eingebaut und im Durchlicht gut erkennbar. Gelegentlich treten sie auch im Auflicht als schwache Ringrippen hervor. Freie Trabekeln kommen bei adulten Formen nicht vor." (Kozur \& Mostler 1989: 180).

Diagnosis (English translation by J. P. Caulet RadWorld database). - "Test clearly three-segmented, imperforate. Apex segmented or unsegmented. Pseudothorax large, strongly inflated, spherical or not. Two lateral spines. Ventral lateral spine very large, somewhat inclined downwards. Its upper border is more or less clearly denticulated. Pseudo-abdomen long, with 3 segments, the distal one strongly curved ventrally, but not, or a little, dorsally recurved. The heart-shaped aperture is, thus, in lateral position on the ventral side, or slightly directed ahead. Columellae connected at the apex, becoming free distally. The free columellae are either perpendicularly to the longitudinal axis of the test, or oriented ventrally and obliquely directed forwards. The free dorsal columella is moderately long and with 3-4 external spines, one of them large. Ventral columella short and smooth, or only with a single very small spine. All trabeculae inserted in the shell and well visible in transmitted light. Occasionally they appear in reflected light as weak annular ribs. No free trabeculae in adult specimens."

\section{REMARKS}

This genus is synonymized with Pseudoalbaillella in De Wever et al. (2001: 93) because of the structural similarity between them. Parafollicucullus is considered the senior synonym to Pseudoalbaillella and by extension to Foremanconus.

\section{Haplodiacanthus Nazarov \& Rudenko, 1981}

Haplodiacanthus Nazarov \& Rudenko, 1981: 133.

TYPE SPECIES. - Haplodiacanthus anfractus Nazarov \& Rudenko, 1981 (Nazarov \& Rudenko 1981: 133, pl. 1, fig. 5-7).

AgE AND LOCATION OF TYPE MATERIAL. - Upper Carboniferous to Lower Permian, Southern Urals, Russia.

TAXON CODE. -033

STATUS. - Junior synonym of Parafollicucullus (by Ishiga et al. 1982b: 274). 
DiAgNOSIS. - “Раковина конусовидная, сегментированная, неперфорированная, пластинчатая, с двумя иглами в апикальной части. Внутренний скелет представлен соединяющимися в верхней части колумемлами, протягивающимися парамлемьно стенки раковины. Характерна гетерогенность сегментации разАичных частей раковины - небольшие сегменты развиты в апикальной части, более крупные - в дистальной. Базацьный сегмент имеет изогнутые отростки." (Nazarov \& Rudenko 1981: 133).

Diagnosis (English translation by A. Kolesnikov). - "Shell is conical, segmented, imperforate, lamellar, with two horns in apical part. The internal skeleton is represented by columellae, which are jointed in the upper part and elongated parallel to the shell wall. There is characteristic heterogeneity of segmentation of different parts of shell: small segments are developed in the apical part; bigger ones are developed in the distal part. The basal segment has a curved appendix."

\section{REMARKS}

This genus was synonymized with Pseudoalbaillella by Ishiga et al. (1982b: 274). Parafollicucullus is considered the senior synonym to Pseudoalbaillella and by extension to Haplodiacanthus.

\section{Holdsworthella Kozur, 1981}

Holdsworthella Kozur, 1981: 268

TYPE SPECIES. - Holdsworthella permica Kozur, 1981 (Kozur 1981: 268, pl. 1, fig. 2, pl. 2, fig. 2, pl. 3, fig. 2).

AgE AND LOCATION OF TYPE MATERIAL. - Sakmarian, Cis-Urals, Russia.

TAXON CODE. - 034 .

STATUS. - Junior synonym of Parafollicucullus (herein).

Diagnosis. - "Wie für die Familie - Schale deutlich in segmentierten Apicalkegel, aufblähten Pseudothorax und z.T. segmentiertes Pseudoabdomen dreigeteilt. Pseudothorax mit zwei kräften Stacheln. Distaler Abschnitt der beiden Columella sehr kräftig ausgebildet, außen mit großen Stacheln. An der Innenseite der ventralen Columella sind noch die kurzen Rudimente zweier Bögen ausgebildet. Übrige Bögen vollständig mit der Schale verschmolzen und nicht mehr erkennbar. Im distalen Dorsalabschnit der Schale sind beiderseits der Columella stets zwei große Poren vorhanden. Der Pseudothorax kann einen Porenring aufweisen." (Kozur 1981: 268).

DiAGNOSIS (English translation by J. P. Caulet RadWorld database modified by Jörg Maletz). - "As for family - Shell differentiated into three part, a segmented apical cone, an inflated pseudothorax and a partly segmented pseudoabdomen. Pseudothorax with two strong spines. Distal ends of both columellae very robust, externally spinose. Two short rudimentary arches on the inner side of the ventral columella. The other arches merged into the shell and no longer recognizable. On the dorsal part of the shell, two large pores always distributed on each side of the columella. The pseudothorax may possess a row of pores."

\section{REMARKS}

The differences between the two species originally included in this genus and Parafollicucullus consist only in them having spines on the dorsal and ventral sides, which does not warrant separate genera.

\section{Ishigaconus Kozur \& Mostler, 1989}

Ishigaconus Kozur \& Mostler, 1989: 181.

TYPE SPECIES. - Follicucullus scholasticus Ormiston \& Babcock, 1979 (by monotypy) (Ormiston \& Babcock 1979: 333, pl. 1, fig. 1-5).

Age and location of type Material. — Guadalupian (Permian), Lamar Limestone, Delaware Basin, USA.

TAXON CODE. - 035 .

STATUS. - Valid.

DiAGNOSIS. - "Gehäuse sehr schlank, spitzkonisch, unperforiert, apical geringfügig bis sehr stark ventralwärts umgebogen, z.T. sogar rückgebogen. Distaler Gehäuseabschnitt z.T. wenig ventralwärts gebogen. Innen ist eine Zweiteilung des Gehäuses in Apicalkegel und distalen Zylinder zu erkennen, außen ist es völlig ungegliedert. Keine Lateralflügel ausgebildet. Apertur groß, nach hinten weisend, nicht eingeengt Die Columella laufen proximal zusammen und stehen distal als relativ kurze, unbestachelte freie Columella über. Die dorsale freie Columella ist länger als die ventrale und proximal durch ein schmales Schalenblatt etwas verbreitert Beide Columella sind nach der Ventralseite geneigt. Bögen zwischen den Columella völlig in die dicke Schale eingebaut und auch im Durchlicht nicht zu erkennen. Nur bei leicht korrodierten Schalen lassen sie sich im Durchlicht undeutlich erkennen. Freie Trabekeln fehlen.” (Kozur \& Mostler 1989: 181).

Diagnosis (English translation by J. P. Caulet RadWorld database - modified by Jörg Maletz). — "Test imperforate, very slender, sharply conical, apically slightly to strongly curved ventrally, even partly recurved. Part of the distal area slightly curved ventrally. Internal part of test divided into an apical cone and a distal cylinder, externally completely unsegmented. No lateral wings. Aperture large, posteriorly well-marked, not narrowing. Columellae proximally connected, but distally protruding as relatively short, non-spinose, free columellae. The dorsal free columella is longer than the ventral one, and sometimes with a thin proximal plate. Both free columellae are ventrally curved. Arches between columellae are completely incorporated into the robust shell and are not even visible in transmitted light. They only appear indistinctly in slightly corroded shells in transmitted light. No free trabeculae."

\section{REMARKS}

Kozur \& Mostler (1989) split Ishigaconus from Follicucullus because of a lack of any inflation of the pseudothorax in the type species. De Wever et al. (2001) considered Ishigaconus a junior synonym of Follicucullus Holdsworth \& Jones, 1980, I. scholasticus falls outside of the description of Follicucullus, and we thus support Kozur \& Mostler (1989) in separating it to establish this new genus.

\section{Longtanella Sheng \& Wang, 1985}

Longtanella Sheng \& Wang, 1985: 179.

TYPE SPECIES. - Longtanella zhengpanshanensis Sheng \& Wang, 1985 (Sheng \& Wang 1985: 179, pl. 3, fig. 11).

Age and location of type material. — Middle Permian, Kufeng Formation, Longtan, Nanjing, China.

TAXON CODE. - 036 . 
STATUS. - Junior synonym of Parafollicucullus (by Dumitrica \& Caridroit in De Wever et al. 2001: 95).

DiAGNOSIS. - "Shell smooth, straight, bilaterally symmetrical turriformis. The shell wall divided into the spire, the turri-body and the turri-bottom composed of ring-like swollen segments. Last segment constrictive, with 4 flaps vertically extending downward." (Sheng \& Wang 1985: 179).

\section{REMARKS}

This genus fits within the parameters of Parafollicucullus and should be treated as a junior synonym.

Parafollicucullus Holdsworth \& Jones, 1980

Parafollicucullus Holdsworth \& Jones, 1980: 285.

Pseudoalbaillella Holdsworth \& Jones, 1980: 285.

Haplodiacanthus Nazarov \& Rudenko, 1981: 133.

Holdsworthella Kozur, 1981: 268 (n. syn.)

Longtanella Sheng \& Wang, 1985: 179.

Curvalbaillella Kozur \& Mostler, 1989: 179.

Foremanconus Kozur \& Mostler, 1989: 180.

Praeholdsworthella Kozur \& Mostler, 1989: 184.

TYPE SPECIES. - Parafollicucullus fusiformis Holdsworth \& Jones, 1980 (Holdsworth \& Jones 1980: 285, app. fig. 1D, E).

Age AND LOCATION OF TYPE MATERIAL. - Permian, chert overlying Mankoment Group, Clearwater Mountains, Alaska Range, USA.

TAXON CODE. - 037 .

STATUS. - Valid.

DiAGNOSIs. - "Bilaterally symmetrical, imperforate siliceous shells of unknown internal structure with apical cone, winged pseudothorax and ring-like pre-pseudoabdominal segment interposed between pseudothorax and pseudoabdomen." (Holdsworth \& Jones 1980: 285).

\section{REMARKS}

The subgenera Kitoconus Kozur \& Mostler, 1989 and Yaoconus Kozur \& Mostler, 1989 are included in Parafollicucullus. Both of these subgenera were listed at the genus rank in De Wever et al. (2001) who synonymized them with Pseudoalbaillella (and by extension with Parafollicucullus).

\section{Praeholdsworthella Kozur \& Mostler, 1989}

Praeholdsworthella Kozur \& Mostler, 1989: 184.

TyPe sPECIES. - Albaillella amplificata Nazarov \& Ormiston, 1985 (Nazarov \& Ormiston 1985: 46, pl. 6, fig. 8, text-fig. 10a).

Age AND LOCATION OF TYPE MATERIAL. - Sakmarian, Cis-Urals, Russia.

TAXON CODE. - 038 .

STATUS. - Junior synonym of Parafollicucullus (by Dumitrica \& Caridroit in De Wever et al. 2001: 93).
DiAGNOSIs. — "Gehäuse dreigeteilt, unperforiert. Apicalkegel unsegmentiert. Pseudothorax recht klein, aber bereits deutlich vom Pseudoabdomen abgesetzt, sphärisch bis subsphärisch. Dorsal und ventral sitzt je ein kleiner bis mäßig langer Seitenstachel an. Pseudoabdomen lang, seitlich abgeflacht, unsegmentiert. Apertur oval, endständig. Die Columella laufen apical zusammen und sind distal frei. Die freien Columella sind sehr lang, hoch, gerade und außen kräftig bestachelt (je 3-4 Stacheln). An der Innenseite der ventralen Columella treten 1-2 Paare von freien Trabekeln auf." (Kozur \& Mostler 1989: 184).

DiAGNOSIS (English translation by J. P. Caulet - RadWorld database). - "Test differentiated into three parts, imperforate. Apical cone unsegmented. Pseudothorax rather small, but well-differentiated from the pseudoabdomen, spherical to sub-spherical. Small to moderately long spines on ventral and dorsal sides. Pseudoabdomen long, laterally flattened, not segmented. Aperture oval, terminal. Columellae apically joined and distally free. Free parts of columellae very long, straight, with external strong spines (3-4). 1-2 pairs of free trabeculae on the inner side of the ventral columella."

\section{REMARKS}

This genus is synonymized with Pseudoalbaillella in De Wever et al. (2001: 93). Parafollicucullus is considered the senior synonym to Pseudoalbaillella and by extension to Foremanconus.

Pseudoalbaillella Holdsworth \& Jones, 1980

Pseudoalbaillella Holdsworth \& Jones, 1980: 285.

TYPE SPECIES. - Pseudoalbaillella scalprata Holdsworth \& Jones, 1980 (Holdsworth \& Jones 1980: 285, app. fig. 1A).

AgE AND LOCATION OF TYPE MATERIAL. - Leonardian, Havallah Formation, Nevada, USA.

TAXON CODE. - 039 .

STATUS. - Junior synonym of Parafollicucullus Holdsworth \& Jones, 1980 (by Kozur 1981: 265).

DiAGNOSIS. - "Bilaterally symmetrical, imperforate, siliceous shells of unknown internal structure showing major division into apical cone, more or less swollen, winged 'pseudothorax' and 'pseudoabdomen'; with or without bilobation of pseudothorax."(Holdsworth \& Jones 1980: 285).

\section{REMARKS}

Kozur (1981) acted as the first reviser and placed Pseudoalbaillella in synonymy with Parafollicucullus. Later, Ishiga (1982) indicated that since Pseudoalbaillella appeared first in the publication by Holdsworth \& Jones (1980), it should have priority. Since Ishiga's publication, the majority of radiolarian works have used Pseudoalbaillella as the senior synonym, including De Wever et al. (2001). However, since Kozur acted as first reviser, his choice of Parafollicucullus stands and must be followed.

\section{Family incertae sedis}

Palacantholithus Deflandre, 1973

Palacantholithus Deflandre, 1973b: 499; 1973a (nomen nudum). 
Type SPECIES. - Palacantholithus stellatus Deflandre, 1973 (Deflandre 1973a: 291, pl. 3, fig. 2-6, pl. 4, fig. 8).

AgE AND LOCATION OF TYPE MATERIAL. — Visean, Cabrières, Hérault, Montagne Noire, France.

TAXON CODE. -040 .

STATUS. — Valid

DiAgNOSIS. - Spicule siliceux avec une courte actine axiale perpendiculaire à une zone centrale de laquelle partent dans un même plan $\mathrm{n}$ actines qui se recourbent ensuite dans le même sens, à l'instar des baleines d'un parapluie ; actines cylindriques, simples ou avec des épines (Deflandre 1973b: 499).

Diagnosis (English translation by J. P. Caulet - RadWorld database). - "Siliceous spicule with a short axial spine perpendicular to a central area from which are issued in the same plane $\mathrm{n}$ spines that are curved in the same direction, as the ribs of an umbrella; spines cylindrical, simple, or with small thorns."

\section{REMARKS}

Re-examination of the holotype from Deflandre's collection shows that it is a spicule with rays disposed in the three Cartesian axes (one ray completely broken off) suggesting that it is a spicule of Haplentactinia type.

\section{Xiphocabrium Deflandre, 1973}

Xiphocabrium Deflandre, 1973b: 500; 1973a (nomen nudum).

TYPE SPECIES. - Xiphocabrium rigidum Deflandre, 1973 (Deflandre 1973a: 293, pl. 3, fig. 8-10).

Age AND location of TYPE MATERIAL. - Visean, Cabrières, Hérault, Montagne Noire, France.

TAXON CODE. - 041

STATUS. - Valid.

DiAGNOSIS. - "Squelette constitué par un long spicule axial cylindrique, rappelant une épée, d'abord élargi dans une zone qui correspondrait à la poignée, puis allant en pointe. Au niveau normal d'une garde inversée, un buisson d'arcs généralement serrés et coalescents, parfois peu nombreux et distincts, s'évase et se termine brusquement ; la partie supérieure porte éventuellement de courtes épines." (Deflandre 1973b: 500).

DiAGNOSIS (English translation by J. P. Caulet - RadWorld database). - "Skeleton consisting of a long cylindrical axial spicule, recalling a sword, first extended in a zone which would correspond to the handle, and up to a point. The normal level of a guard reversed, a bush of tight arcs and usually coalescing, sometimes few and distinct flares and abrupt terminations; the top may or may not bear short spines."

\section{Xiphocladiella Deflandre, 1973}

Xiphocladiella Deflandre, 1973a: 499; 1960 (nomen nudum).

Type SPECIES. - Xiphocladiella cuja Deflandre, 1960 (Deflandre 1960: 216, pl. 1, fig. 27 [nomen nudum]); Deflandre 1973a: 291, pl. 4, figs 1-3.
Age And location of type material. - Visean, Cabrières, Hérault, Montagne Noire, France.

TAXON CODE. - 042 .

STATUS. - Valid

DiAgNOSis. - "Squelette composé d'un long spicule axial tricostulé, dont la partie supérieure, sur la moitié environ, est très élargie puis se rétrécit progressivement; zone médiane ornée de quelques cornes minces, diversement orientées; extrémité inférieure se terminant par quelques cornes, droites ou recourbées, parfois ramifiées." (Deflandre 1973b: 499).

Diagnosis (English translation by J. P. Caulet - RadWorld database). - "Skeleton consisting of a long tricostulate axial spike, the upper part, on about half, is very broad and tapers; middle area adorned with a few thin horns, variously oriented; lower end terminating in a few horns, straight or curved, sometimes branched."

\section{REMARKS}

In the slide BD54, R45/3 of Deflandre's collection, there is a very well preserved specimen (the holotype) that proves that it is a ceratoikiscid. The left side is broken off and the ribs are weakly developed. This specimen shows its structure better when the slide is observed upside down (located F45/3). Another specimen, even better preserved, that proves the ceratoikiscid nature, is in the slide BD 82, G37/4. It has two main pairs of ribs and one pair shorter. Re-examination of these specimens suggests that both Xiphocladiella cuja and Xiphachistrella acipiens are ceratoikiscids and may possibly belong to the same species, but for now only Xiphachistrella is synonymized with Ceratiokiscum.

\section{Order ARCHAEOSPICULARIA}

Dumitrica, Caridroit \& De Wever, 2000

Family ArChEOENTACTINIIDAE Won \& Below, 1999

\section{Archeoentactinia Won in Won \& Below, 1999}

Archeoentactinia Won in Won \& Below, 1999: 332.

TYPE SPECIES. - Archeoentactinia incaensis Won in Won \& Below, 1999 (Won \& Below 1999: 333, pl. 6, fig. 1-9, 16, 17, pl. 8, fig. 16 19, pl. 10, fig. 5-6).

Age and location of type material. - Middle Cambrian, Georgina Basin, Queensland, Australia.

TAXON CODE. -043 .

STATUS. - Valid

DiAGNOSIS. - "A skeleton consisting of a disorderly and threedimensional interwoven spherical meshwork layer, with a fairly large empty ventral space in the shell, one or two spicules that are generally four- to six-rayed; the central point of the spicules positioned eccentrically in the shell, in general, very close to the shell wall layer." (Won \& Below 1999: 332).

Lithosphaera Won, 1998

Lithosphaera Won, 1998: 256. 
TYPe SPECIES. — Lithosphaera oesensis Won, 1998 (Won 1998: 256, pl. 4, fig. 14-15)

AgE AND LOCATION OF TYPE MATERIAL. — Tournaisian, Rheinische Schiefergebirge, Germany.

TAXON CODE. - 044 .

STATUS. - Homonym.

DiAGNOSIS. - "A spherical spongy shell with an internal spicule consisting of two sets of three or more (?) rays attached at a meeting point, each of the six or more (?) rays of the spicule bearing apophyses whose branches connect with the meshwork of the shell wall" (Won 1998: 256).

\section{REMARKS}

A poriferan genus described by Ehrenberg (1843) bears the same name.

\section{Pararcheoentactinia Won \& Iams, 2002}

Pararcheoentactinia Won \& Iams, 2002: 9.

TyPe SPECIES. - Pararcheoentactinia reedae Won \& Iams, 2002 (Won \& Iams 2002: 9, fig. 8.1-8.21, 9.1-9.20, 10.1-10.20).

Age AND location of TyPe MATERIAL. - Upper Cambrian, Cow Head Group, Western Newfoundland, Canada.

TAXON CODE. -045 .

STATUS. - Valid.

DiAGNOSIS. - "A skeleton with a spherical shell and one point centered spicule. The spherical shell varying from a disorderly and threedimensionally interwoven primitive meshwork of straight to slightly curved bars to a typical spongy tissue. The point-center of the spicule positioned from eccentrically within the central shell cavity to immediately adjacent to the innermost shell wall; rays with or without spinules (or trace of spinules); spinules with or without connection to the shell meshwork, but where all the spinules connected to the shell wall, the rays forming a part of the shell wall; rod-like rays protruding out of the shell wall as outer spines." (Won \& Iams 2002: 9).

Sphaeroentactinia Maletz \& Bruton, 2007

Sphaeroentactinia Maletz \& Bruton, 2007: 263.

TYPE SPECIES. - Sphaeroentactinia hexaspinosa Maletz \& Bruton, 2007 (Maletz \& Bruton 2007: 264, fig. 6A, 12A-I).

AGE AND LOCATION OF TYPE MATERIAL. - Didymograptellus bifidus and Isograptus lunatus graptolite zones, Floian (Lower Ordovician), Valhallfonna Formation, Spitsbergen.

TAXON CODE. - 046

STATUS. — Valid.

DiAGNOSIS. - "Spherical radiolarians with a bar-centered spicule and a sphere formed from apophyses; spicule eccentrically positioned; spines may or may not be incorporated in the three-dimensional skeleton.” (Maletz \& Bruton 2007: 263).

\section{REMARKS}

This genus is tentatively placed within the Archaeospicularia, but may be an entactinarian.

\section{Spongomassa Won in Won \& Below, 1999}

Spongomassa Won in Won \& Below, 1999: 337.

TYPE SPECIES. - Spongomassa gigantea Won in Won \& Below, 1999 (Won \& Below 1999: 337, pl. 7, fig. 1-8).

Age and location of type material. - Middle Cambrian, Georgina Basin, Queensland, Australia.

TAXON CODE. -047 .

STATUS. - Valid.

DiAGNOSIS. - "A skeleton consisting of a mass of spongy tissue, rays of the spicule, and spines; delicate threads interwoven between radial rays and rays of the spicule; no definite inner empty space; central point of the spicule positioned eccentrically deep inside the shell.” (Won \& Below 1999: 337).

Family ECHIDNINIDAE Kozur, Mostler \& Repetski, 1996

\section{Aitchisonellum Won in Won \& Below, 1999}

Aitchisonellum Won in Won \& Below, 1999: 352.

TYPE SPECIES. - Aitchisonellum aspinosus Won in Won \& Below, 1999 (Won \& Below: 356, pl. 8, fig. 1-5, pl. 10, fig. 9-10).

Age AND location of TYPe MATERIAL. - Upper Cambrian, Mungerebar Limestone, western Queensland, Australia.

TAXON CODE. -048 .

STATUs. - Junior synonym of Parechidnina Kozur, Mostler \& Repetski, 1996 (by Won et al. 2005: 443).

DiAGNOSIS. - "A spherical shell, with a thin to fairly thick shell wall that is composed of irregularly interwoven threadlike elements; no internal spicule." (Won in Won \& Below 1999: 352).

\section{REMARKS}

This species was synonymized by Won \& Iams (2002: 30 see also p. 7). The diagnosis of Parechidnina by Kozur et al. (1996) is based on a misconception of this taxon, as explained by Won in the discussion section of Parechidnina (Won \& Iams 2002: 19-23).

\section{Altaiesphaera Obut \& Iwata, 2000}

Altaiesphaera Obut \& Iwata, 2000: 34.

Archaeocenosphaera Obut \& Iwata, 2000: 33 (n. syn.)

TYPE SPECIES. - Altaiesphaera acanthophora Obut \& Iwata, 2000, p. 35, pl. 1, fig. 11-15

Age AND location of TyPe MATERIAL. — Lower Cambrian, Altai Mountains, Russia.

TAXON CODE. - 049 .

STATUS. — Valid.

DiAGNOSIS. - "Spheroidal radiolarians with porous cortical shell. Rob-like thin spines. Pores of polyhedral or irregular shapes are developed on overall shell surface". (Obut \& Iwata 2000: 34) 


\section{Archaeocenosphaera Obut \& Iwata, 2000}

Archaeocenosphaera Obut \& Iwata, 2000: 33.

TYPE SPECIES. - Archaeocenosphaera muricata Obut \& Iwata, 2000 (Obut \& Iwata 2000: 34, pl. 1, figs 1-3, 6-7).

AGE AND LOCATION OF TYPE MATERIAL. — Lower Cambrian, Gorny Altai, Southern West Siberia.

TAXON CODE. -050 .

STATUS. - Junior synonym of Altaiesphaera Obut \& Iwata, 2000 (herein).

DiAGNOSIS. - "Spheroidal oval radiolarians with one porous cortical shell, $80-100 \mu \mathrm{m}$ diameter. Internal suture or spicules remain uncertain." (Obut \& Iwata 2000: 33).

\section{REMARKS}

In addition to being a junior synonym of Altaiesphaera, it is also a homonym of a Mesozoic radiolarian genus (type species Archaeocenosphaera ruesti Pessagno \& Yang in Pessagno, Six \& Yang, 1989).

\section{Cancellisphaera Won \& Iams, 2015}

Cancellisphaera Won \& Iams, 2015: 19.

TyPe SPECIES. - Cancellisphaera kozuri Won \& Iams, 2015 (Won \& Iams 2015: 20, pl. 4, fig. 8a, b).

AgE AND LOCATION OF TYPE MATERIAL. - Upper Floian (Lower/ Middle Arenig), Cow Head Group, Western Newfoundland, Canada.

TAXON CODE. - 051 .

STATUS. - Valid.

DiAGNOSIS. - "Test spherical with regularly latticed meshwork surrounding a six- rayed, bar-centered spicule. Outer extensions of the rays developed as robust spines and are much thicker than their inner parts, which are thin and delicate. Outer spines surrounded by spinules. Spinules adjacent to the spherical shell are connected to the shell mesh work." (Won \& Iams 2015: 19).

\section{Curvechidnina Won \& Iams, 2002}

Curvechidnina Won \& Iams, 2002: 23.

TYPE SPECIES. - Curvechidnina tetractina Won \& Iams, 2002 (Won \& Iams 2002: 24, figs 7.9-7.13).

Age ANd location of Type Material. - Upper Cambrian, Cow Head Group, Western Newfoundland, Canada.

TAXON CODE. - 052 .

STATUS. - Valid.

DIAGNOSIS. - "A shell consisting of numerous point-centered spicules with four to ten curved rays and all rays directed outwardly. The shell characterized by numerous outer spines that are the distal part of rays, with the proximal parts of rays forming a shell wall with a relatively smooth, spherical to subspherical inner surface; spicules densely or loosely interlocked or fused, or modified and fused." (Won \& Iams 2002: 23).
Echidnina Bengtson, 1986

sensu Won \& Iams (2002)

Echidnina Bengtson, 1986: 202. — Won \& Iams 2002: 24.

TYPE SPECIES. - Echidnina runnegari Bengtson, 1986 (Bengtson 1986: 202, fig. 4A-F, 11E).

AgE AND LOCATION OF TYPE MATERIAL. - Upper Cambrian, Mungerebar Limestone, western Queensland, Australia.

TAXON CODE. - 053 .

STATUS. - Valid.

DiAGNOSIS. - "Globular spiny bodies, 210-300 $\mu \mathrm{m}$ in diameter (excluding protruding spicule rays), built up of disorderly arranged, siliceous, slender, hexactinellid-type spicules up to $5 \mu \mathrm{m}$ in thickness. No axial filament visible in spicules. Interior of globules hollow." (Bengtson 1986: 202).

\section{REMARKS}

Won \& Iams (2002) emended the diagnosis, specifying that the individual spicules may be interlocked or fused, maintaining their individual spicular structure, while forming a hollow spherical shell. They also removed reference to sponge spicule terminology, as it was originally assumed by Bengtson that this genus was a poriferan.

Gigantospiculum Won \& Iams, 2015

Gigantospiculum Won \& Iams, 2015: 16.

TyPe SPECIES. - Gigantospiculum dumitricai Won \& Iams, 2015 (Won \& Iams 2015: 17, pl. 4, fig. 2a, b).

AgE AND LOCATION OF TYPE MATERIAL. - Upper Floian (Lower/ Middle Arenig), Cow Head Group, Western Newfoundland, Canada.

TAXON CODE. -054

STATUS. — Valid.

DiAGNOSIS. - "Skeleton consisting of an extraordinarily large, median bar-centered spicule with multi-rays and delicate and wide open shell meshwork consisting of minor modified and fused spicules. Major spicule and meshwork fused or interlocked with one another." (Won \& Iams 2015: 16).

\section{Grosmorneus Won \& Iams, 2002}

Grosmorneus Won \& Iams, 2002: 31.

TYPE SPECIES. — Grosmorneus globosus Won \& Iams, 2002 (Won \& Iams 2002: 31, figs 4.17-4.20).

Age And location of type Material. - Upper Cambrian, Cow Head Group, Western Newfoundland, Canada.

TAXON CODE. -055 .

STATUS. - Valid.

DiAGNOSIS. - "A skeleton consisting of a six-rayed median barcentered spicule and spinules. Proximally positioned, robust, radially distributed first-order spinules present; may or may not form a spherical shell." (Won \& Iams 2002: 31). 
Neoechidnina Won \& Iams, 2015

Neoechidnina Won \& Iams, 2015: 15.

TYPE SPECIES. - Neoechidnina compacta Won \& Iams, 2015 (Won \& Iams 2015: 15, pl. 3, fig. 2-3a, b).

AgE AND LOCATION OF TYPE MATERIAL. - Upper Floian (Lower/ Middle Arenig), Cow Head Group, Western Newfoundland, Canada.

TAXON CODE. -056

STATUS. - Valid.

DiAGNOSIS. - "Spherical shell consisting of a modified spicule whose original echininid spicule structure is almost unrecognizable; dense skeletal bar-like elements irregularly arranged and fused to form a thick shell wall. Rough outer surface with randomly directed small projections (rays), inner surface smooth." (Won \& Iams 2015: 15).

Parechidnina Kozur, Mostler \& Repetski, 1996 sensu Won et al. (2005)

Parechidnina Kozur, Mostler \& Repetski, 1996: 249.

Aitchisonellum Won in Won \& Below, 1999: 352.

TYPE SPECIES. - Parechidnina nevadensis Kozur, Mostler \& Repetski, 1996 (Kozur et al. 1996: 250, pl. 1, fig. 5, pl. 2, fig. 1, 3).

Age ANd LOCATION OF TYPE MATERIAL. - Lower Tremadocian, Windfall Formation, Antelope Range, Eureka County, Nevada, USA.

TAXON CODE. -057 .

STATUS. — Valid.

Diagnosis. - "Heptactine, hexactine, pentactine and tetractine spicules are fused to a loose, hollow, irregular latticed shell with large, triangular to rectangular or rhombohedral pores and numerous needle-like outward-directed spines. Connecting bars between these spines and further fused spicules above the shell form an imperfect, loose spongy shell. In the largest part of the test both shells are united to a single, loose spongy shell." (Kozur et al. 1996: 249).

\section{Subechidnina Won \& Iams, 2002}

Subechidnina Won \& Iams, 2002: 26.

TYPe SPECIES. - Subechidnina gracilis Won \& Iams, 2002 (Won \& Iams 2002: 27, fig. 6.17-6.19).

Age And location of TYPE MATERial. - Upper Cambrian, Cow Head Group, Western Newfoundland, Canada.

TAXON CODE. - 058 .

STATUS. - Valid.

DIAGNOSIS. - "Isolated or modified spicules interlocked or fused to form a hollow spherical shell. Number of spicules between 10 and 25 , each spicule possessing 10 to 30 rays. Inwardly directed rays reduced, thus shorter than the other rays, or present only as nodes, and the outwardly directed rays with or without reduction." (Won \& Iams 2002: 26).
Varispiculum Won \& Iams, 2015

Varispiculum Won \& Iams, 2015: 17.

TYPe SPECIES. - Varispiculum ectospiculatum Won \& Iams, 2015 (Won \& Iams 2015: 17, pl. 5, fig. 9a, b).

Age And location of type Material. - Upper Floian (Lower/ Middle Arenig), Cow Head Group, Western Newfoundland, Canada.

TAXON CODE. - 059 .

STATUS. - Valid.

DiAGNOSIS. - "Spherical shell with a prominent median bar-centered spicule, which may be located within the shell wall, or under it, or in the shell cavity. Shell characterized by an intricate interlacing of straight bars in an irregular and angular three dimensional meshwork. Minor spicule(s) or fused spicule structure commonly developed. Rays with spinules connected to shell meshwork. Outer surface rough with variably directed projections and inner surface smooth." (Won \& Iams 2015: 17).

Westernbrookia Won, Iams \& Reed, 2007

Westernbrookia Won, Iams \& Reed, 2007a: 517.

TYPE SPECIES. - Westernbrookia diversa Won, Iams \& Reed, 2007 (Won et al. 2007a: 519, fig. 15.1-15.12).

AgE AND LOCATION OF TYPE MATERIAL. - Upper Tremadocian, Cow Head Group, western Newfoundland, Canada.

TAXON CODE. - 060 .

STATUS. - Valid.

DiAGNOSIS. - "Oval, subspherical, or spherical skeleton consisting of a layered shell wall with dense polygonal meshwork on which delicate fine skeletal may developed; internal structure extremely diverse, some eccentricity in internal structures; pylome present." (Won et al. 2007a: 517).

\section{Family ProtoentactiniIDAE}

Kozur, Mostler \& Repetski, 1996

Noblella Kozur, Mostler \& Repetski, 1996

Noblella Kozur, Mostler \& Repetski, 1996: 255.

TYPE SPECIES. - Noblella tremadociensis Kozur, Mostler \& Repetski, 1996 (Kozur et al. 1996: 255, pl. 7, fig. 3).

AgE AND LOCATION OF TYPE MATERIAL. - Tremadocian, Lower Ordovician, Windfall Formation, Antelope Range, Nevada, USA.

TAXON CODE. - 061.

STATUS. - Homonym and Junior synonym of Protoentactinia (homonymy recognized and replacement name Paulanobella introduced by Kozur \& Repetski [2002]).

DIAGNOSIS. - "The robust spicular system is branched in its largest part, in the manner typical of the Protoentactiniidae (median bar with 3-4 terminal rays), and forms an ovoid to subglobular, loose spongy test. The most robust rays of the spicular system are con- 
centrated on one side of the test, and 2 robust terminal rays (out of 4 ) in this portion of the test are different from all other rays in being straight, unbranched, but having 3-4 verticiles, from which needle-like spines originate." (Kozur et al. 1996: 255).

\section{REMARKS}

This genus name is a homonym with an amphibian and the replacement name, Paulanoblella, was later proposed (Kozur \& Repetski 2002). Paulanoblella is considered a junior synonym to Protoentactinia (See remarks under Paulanoblella).

\section{Paulanoblella Kozur \& Repetski, 2002}

Paulanoblella Kozur \& Repetski, 2002: 28.

Nomem novum for Noblella Kozur, Mostler \& Repetski, 1996: 255.

TYPE SPECIES. - Noblella tremadociensis Kozur, Mostler \& Repetski, 1996 (Kozur et al. 1996: 255, pl. 7, fig. 3).

Age AND LOCATION OF TYPE MATERIAL. - Tremadocian, Lower Ordovician, Windfall Formation, Antelope Range, Nevada, USA.

TAXON CODE. - 062 .

STATUS. - Junior synonym of Protoentactinia (by Won et al. 2005: 453).

Diagnosis. — As for Noblella Kozur, Mostler \& Repetski, 1996.

\section{REMARKS}

This name was proposed as a replacement name for the homonym Noblella. Won et al. (2005) consider it a variant of Protoentactinia. Despite the more robust nature of the spicule, the type species, Paulanoblella tremadociensis, bears all of the characters diagnostic of Protoentactinia. The more robust spicule appears to be a species level distinction and does not warrant the creation of a new genus.

\section{Protoentactinia Kozur, Mostler \& Repetski, 1996}

Protoentactinia Kozur, Mostler \& Repetski, 1996: 253.

Paulanoblella Kozur \& Repetski, 2002: 28.

TyPe sPeCIES. - Protoentactinia gracilispinosa Kozur, Mostler \& Repetski, 1996 (Kozur et al. 1996: 253, pl. pl. 3, fig. 1).

Age AND location of TYPE MATERial. - Lower Tremadocian, Windfall Formation, Antelope Range, Eureka County, Nevada, USA.

TAXON CODE. - 063 .

STATUS. - Valid.

DiAgNOSIS. - "The rarely fully preserved subglobular test consists of a repeatedly branched entactinarian spicular system that forms a spongy network. The inner part of this network is very loose, the outer part is somewhat denser, but also loose. A small empty space may be present inside the test, but often this space also is filled by the spicular system. The spicular system consists basically of a median bar and 3, rarely 4, terminal rays. In the outer part of the test, both the median bar and the terminal rays are mostly shorter and only a little outward- directed. The ends of the branches are fused or interlocked there. In this part not only 3 or 4 , but partly also 2 , and rarely more than 4, terminal branches occur. Rarely, some isolated, but interlocked spicules also are present in the outer part. In general, all the branches of the spicular system have the same diameter. Only in the outer part they are somewhat slenderer, but in general, there is no distinct separation between an inner spicular system and an outer shell. Only in exceptional cases are the inner branches much thicker than the outer one." (Kozur et al. 1996: 253).

Protospongentactinia Won, Iams \& Reed, 2007

Protospongentactinia Won, Iams \& Reed, 2007a: 531.

TYPE SPECIES. - Protospongentactinia spongiosa Won, Iams \& Reed, 2007 (Won et al. 2007a: 532, figs 6.10, 6.11).

Age AND location of tYPE MATERial. - Lower Ordovician, Cow Head Group, western Newfoundland.

TAXON CODE. -064 .

STATUS. — Valid.

DiAGNOSIS. - "Protoentactiniid internal structure and a meshed or spongy spherical shell wall." (Won et al. 2007a: 531).

Family Palaeospiculidae Won in Won \& Below, 1999

Palaeospiculumidae - Won in Won \& Below 1999: 338 (nom. corr. Maletz [2011a: 130]).

Neopalaeospiculum Won, Iams \& Reed, 2007

Neopalaeospiculum Won, Iams \& Reed, 2007a: 525.

Type SPECIES. - Neopalaeospiculum laxum Won, Iams \& Reed, 2007 (Won et al. 2007a: 525, fig. 5.4-5.6).

Age AND location of type Material. - Upper Tremadocian, Cow Head Group, western Newfoundland, Canada.

TAXON CODE. -065 .

STATUS. - Valid.

DiAGNOSIS. - "A six-rayed spicular skeleton with a spherical shell wall made up of partly or completely fused meshwork. Four or five radially arranged first-order spinules developed at one or two nodes on the rays, these spinules with or without second- or at most, third-order spinules, also radially arranged. Spinules near the shell wall possessing branches, and both elements forming a thin one-layered, three-dimensionally interwoven shell wall." (Won et al. 2007a: 525).

\section{Palaeospiculum Won in Won \& Below, 1999}

Palaeospiculum Won in Won \& Below, 1999: 339.

Type SPECIES. - Palaeospiculum burkensis Won in Won \& Below, 1999 (Won \& Below 1999: 340, pl. 1, fig. 8-12, 20, 22, pl. 2, fig. 13, pl. 3, fig. 1). 
Age and location of type material. - Middle Cambrian, Georgina Basin, Queensland, Australia.

TAXON CODE. - 066 .

STATUS. - Valid.

DiAGNOSIS. - "A spicular skeleton with three to six rods crossing at a point, each rod divided into apical and basal rays; all rays with spinules, or apical rays lacking spinules; where all rays have spinules, more spinules are present on the basal rays than on the apical rays. In general, secondary spinules or thorns on the primary spinules." (Won in Won \& Below 1999: 339).

\section{Ramuspiculum Won \& Iams, 2002}

Ramuspiculum Won \& Iams, 2002: 29.

TYPe SPECIES. - Ramuspiculum multiramosum Won \& Iams, 2002 (Won \& Iams 2002: 29, fig. 4.1-4.4).

Age AND location of Type Material. - Upper Cambrian, Cow Head Group, Western Newfoundland, Canada.

TAXON CODE. - 067 .

STATUS. — Valid.

DiAGNOSIS. - "A point-centered spicular skeleton of four to six rays, rays with three to five radially arranged spinules at one position near their mid-points. Ray repeatedly as many as five times trifurcate at their tips." (Won \& Iams 2002: 29).

\section{Svalbardospiculum Maletz \& Bruton, 2007}

Svalbardospiculum Maletz \& Bruton, 2007: 259.

TYPE SPECIES. - Svalbardospiculum arenigium Maletz \& Bruton, 2007 (Maletz \& Bruton 2007: 259, fig. 4A, 10A-O).

AgE AND LOCATION OF TYPE MATERIAL. - Didymograptellus bifidus and Isograptus lunatus graptolite zones, Floian, Lower Ordovician, Valhallfonna Formation, Spitsbergen.

TAXON CODE. - 068

STATUS. - Valid.

DiAGNOSIS. - "Palaeospiculumid spicule with more than one generation of whorled rays; apophyses may be present or not; skeleton polarized." (Maletz \& Bruton 2007: 259).

\section{Family SeCUiCOlLaCtidae Nazarov \& Ormiston, 1984}

\author{
Diparvapila MacDonald, 1998 \\ sensu MacDonald (2003)
}

Diparvapila MacDonald, 1998: 594; 2003: 114.

Parvalanapila MacDonald, 1998: 597; 2006b: 207.

TYPE SPECIES. - Diparvapila hicocki MacDonald, 1998 (MacDonald 1998: 595, fig. 4.6, 4.10-4.12, 8.9-8.11).

AgE AND LOCATION OF TYPE MATERIAL. - Upper Llandovery, Cape Phillips Formation, Cornwallis Island, Arctic Canada.
TAXON CODE. -069 .

STATUS. - Valid.

DiAgNOSIs. - "Secuicollactinae with two spherical lattice shells; pentactine or hexactine spicule ectopically placed on medullary shell, one ray perpendicular to others; single primary spine unit with medullary shell gives rise to antapical spine" (MacDonald 1998: 594).

\section{REMARKS}

In his dissertation, MacDonald (2003: 114) emends the diagnosis to include forms where the outer shell is either labyrinthine or latticed, thus including species previously split out into his genus Parvalanapila MacDonald, 1998. The emended diagnosis was not formally published, however the type species of Parvalanapila, P. fleischerorum is considered a Diparvipila by MacDonald (2006b: 207).

\section{Palaeosphaera Renz, 1990}

Palaeosphaera Renz, 1990: 372.

TYPe SPECIES. - Palaeosphaera micra Renz, 1990 (Renz 1990: 372, pl. 1, fig. 7, 9).

AgE AND LOCATION OF TYPE MATERIAL. - Upper Ordovician (Katian), Nevada, USA.

TAXON CODE. -070 .

STATUS. - Junior synonym of Secuicollacta Nazarov \& Ormiston, 1984 (herein)

DiAGNOSIS. - "A relatively small, single, non-pylomate sphere with four to six moderate primary spines. No secondary spines or internal structure. Primary spines are straight, round in cross section and taper distally. Pores are irregularly rounded, small, slightly variable in size." (Renz 1990: 372).

\section{REMARKS}

Examination of one of the published photos of the type species (Renz 1990: pl. I, fig. 9) clearly shows that the spines in the northern hemisphere of the photo are part of an ectopic spicule. Examination of topotype material collected by the first author confirms that the type species is attributable to Secuicollacta.

\section{Parasecuicollacta Won, Blodgett \& Nestor, 2002}

Parasecuicollacta Won, Blodgett \& Nestor, 2002: 953.

TyPe SPECIES. - Parasecuicollacta bipola Won, Blodgett \& Nestor, 2002 (Won et al. 2002: 953, fig. 3.1-3.6, 3.14-3.17).

AgE AND LOCATION OF TYPE MATERIAL. - Llandoverian, Lower Silurian, Road River Formation, Alaska, USA.

TAXON CODE. -071 .

STATUS. - Junior synonym of Secuicollacta Nazarov \& Ormiston, 1984 (by Jones \& Noble 2006).

DiAGNOSIS. - Spherical skeleton consisting of a single shell with zero to 12 or more primary spines; shell wall thick with six (or 
fewer?) to 12 or more primary units consisting of four to seven primary rods, each with or without a primary spine; meshwork consisting of primary and secondary rods; except for the spines; all skeletal elements of the outer surface producing a lumpy surface or one covered with ragged elements that can form a pseudospongy very thin and delicate layer covering the shell; no internal structure present." (Won et al. 2002: 953).

\section{REMARKS}

The lumpy or ragged surface appears to be a function of the development of secondary spines and was deemed insufficient to warrant a new genus (MacDonald 2003; Jones \& Noble 2006).

\section{Parvalanapila MacDonald, 1998}

Parvalanapila MacDonald, 1998: 597.

Type species. - Parvalanapila fleischerorum MacDonald, 1998 (MacDonald 1998: 599, fig. 5.8, 5.11, 9.1-9.5).

AgE AND LOCATION OF TYPE MATERIAL. - Llandoverian, Lower Silurian, Cape Phillips Formation, Cornwallis Island, Arctic Canada.

TAXON CODE. -072 .

STATUS. - Junior synonym of Diparvapila MacDonald, 1998 (by MacDonald 2006b: 207).

DiAGNOSIS. - "Secuicollactinae with single lattice shell covered by labyrinthine layer formed of interlocking apophyses arising from short spinules off lattice and from spines; spicule ectopically placed on lattice sphere; single primary unit with lattice shell, gives rise to antapical spine." (MacDonald 1998: 597).

\section{REMARKS}

The main difference between this genus and Diparvipila, as noted by MacDonald (1998), is the wooly versus latticed outer layer. Further observation of the type species (MacDonald 2003), reveals a fair amount of variation in the outer layer, causing MacDonald to consider synonymous with Diparvipila. In a later publication the type species of Parvalanapila appears as Diparvapila fleischerorum (MacDonald 2006b: 207).

\section{Pseudorotasphaera Noble, 1994}

Pseudorotasphaera Noble, 1994: 25.

TyPe SPECIES. - Pseudorotasphaera hispida Noble, 1994 (Noble 1994: 25, pl. 3, fig. 5-7, pl.4, fig. 3-4).

AgE AND LOCATION OF TYPE MATERIAL. - Silurian, zones 1 and 2 of Noble (1994), Payne Hills, Marathon uplift, west Texas, USA.

TAXON CODE. - 073 .

STATUS. — Valid.

DiAGNOSIs. - "Latticed cortical shell polygonal to subpolygonal in outline with six to seven robust, grooved primary spines. Pore frames are angular to subcircular. Each spine base possesses five to six rods, which are continuous with the spine ridges. A loosely latticed medullary shell attaches to the cortical shell by primary bars which extend to each primary spine, and by thin secondary bars connecting to other points on the cortical shell." (Noble 1994: 25).
Rotasphaera Noble, 1994

Rotasphaera Noble, 1994: 19.

TyPE SPECIES. - Rotasphaera marathonensis Noble, 1994 (Noble 1994: 21, pl. 2, fig. 1-4, pl. 8, fig. 1-2).

Age AND Location of TyPe MATERial. - Silurian, Caballos Novaculite, Texas, USA.

TAXON CODE. -074 .

STATUS. - Junior synonym of Secuicollacta Nazarov \& Ormiston, 1984 (by Dumitrica et al. 2000).

DiAGNOSIS. - "Shell may be round to polygonal in outline with six to nine primary spines which are morphologically distinct from the secondary spines. Primary spines are commonly blunt-ended or tapered, may exhibit blades or grooves at the proximal end, and are circular in cross section at the distal end. Secondary spines are commonly thin non-tapered rods or nodes which range from 5 to $50 \%$ of the primary spine length.” (Noble 1994: 19).

\section{REMARKS}

Noble (1994) distinguished Rotasphaera from Secuicollacta Nazarov \& Ormiston 1984 by the fewer number of primary spine units and greater differentiation between primary and secondary spines. There has been some discussion in the literature as to whether Rotasphaera should be considered a junior synonym to Secuicollacta (Jones \& Noble, 2006). MacDonald (1998; 2003) maintained that the two genera should be separate, and that Rotasphaera lacked an ectopic spicule. Herein, we include Rotasphaera in Secuicollacta despite differences between primary and secondary spine morphology. The absence of an ectopic spicule in the secuicollactines recovered from Caballos material (Noble 1994) is likely a function of preservation.

\section{Secuicollacta Nazarov \& Ormiston, 1984 sensu MacDonald (1998)}

Secuicollacta Nazarov \& Ormiston, 1984: 75. — MacDonald 1998: 587.

Palaeosphaera Renz, 1990: 372 (n. syn.)

Rotasphaera Noble, 1994: 19.

Parasecuicollacta Won, Blodgett \& Nestor, 2002: 953.

TyPe SPECIES. - Secuicollacta cassa Nazarov \& Ormiston, 1984 (Nazarov \& Ormiston 1984: 75, pl. 4, fig. 5).

Age AND location of tyPE MATERIAL. - Silurian, Southern Urals, Russia.

TAXON CODE. -075 .

STATUS. - Valid.

DIAGNOSIS. - "Haplentactiniidae с эктопическим расположением внутреннего каркаса, который представлен 5-6 и более кучами. Развитие апофизов на мучах и их соединение образуют 1-2 изометричные грубосетчатые оболочки” (Nazarov \& Ormiston 1984: 75). 
DiAGNOSIS (English translation). _ " "Haplentactinidae with an ectopic location of inner spicule which contains 5-6 or more rays. Development of apophyses on rays and their connection form 1-2 coarse-meshed isometric shells".

\section{REMARKS}

MacDonald (1998) emends the broad diagnosis of Nazarov \& Ormiston (1984) to exclude two-shelled forms such as species he placed in Diparvapila, restricting Secuicollacta to single shelled species, whose shell is formed "mainly of primary units; spicule ectopically placed, three to six rays with one ray perpendicular to other rays; spicule rays continue directly as spines" (MacDonald 1998: 587).

\section{Order ENTACTINARIA Kozur \& Mostler, 1982 Family ENTACTINIIDAE Riedel, 1967}

Afanasievella Nestell \& Nestell, 2010

Afanasievella Nestell \& Nestell, 2010: 22.

TYPe SPECIES. - Afanasievella apachensis Nestell \& Nestell, 2010 (Nestell \& Nestell 2010: 23, pl. 8, fig. 4, 6, pl. 9, fig. 1-5)

AgE AND LOCATION OF TYPE MATERIAL. - Upper Capitanian, Guadalupian, Middle Permian, West Texas, USA.

TAXON CODE. -076 .

STATUS. — Valid.

DiAgNOSIS. - "Test bipyramidal in shape, with three shells: spongy external shell, porous intermediate shell and microsphere. Between microsphere and intermediate shell six thin rod-like rays develop which continue outside of microsphere as primary threebladed radial beams extending outside as main spines. Between intermediate and external shells, radial thin and rod-like beams and secondary small conical spines are developed. The ends of the radial beams are bifurcated as are the apophyses that connect with each other and form the internal or basal layer of the spongy external shell. Three rows of the linear apophyses are developed at the distal end of the primary three-bladed radial beams." (Nestell \& Nestell 2010: 22).

\section{Apophysiactinia Won, 1997}

Apophysiactinia Won, 1997a: 362.

Type sPecies. - Apophysiactinia trispinula Won, 1997 (Won 1997a: 364, pl. 6, fig. 13, 14, 17).

Age AND location of type MATERIAL. - Frasnian (Upper Devonian), Gogo Formation, Canning Basin, Western Australia.

TAXON CODE. -077.

STATUS. - Valid.

DiAGNOSIS. - "With or without (?) a spherical shell, six rays arising from a median microbar, each ray having three apophyses at one or two levels. The apophyses can be elements of mesh forming a very loosely constructed shell or lie free on spines. Microthorns present along the rays and apophyses." (Won 1997a: 362).

\section{REMARKS}

This genus is assigned to the Family Archaeosemantidae Kozur \& Mostler 1981 the definition of which was emended by De Wever et al. (2001).

\section{Apophysisphaera Won, 1997}

Apophysisphaera Won, 1997b: 372.

TyPE SPECIES. - Entactinia profundisulcus Aitchison, 1993 (Aitchison 1993b: 114, pl. 7, fig. 7-8).

Age And location of TYPe MATERial. - Upper Devonian, Gogo Formation, Canning Basin. Western Australia.

TAXON CODE. -078 .

STATUS. - Junior synonym of Stigmosphaerostylus Rüst, 1892 (Dumitrica in De Wever et al. 2001: 180).

DiAGNOSIS. - "The spherical test has one latticed shell. Irregularly to hexagonally latticed shell has additional spongy tissue and/or microsepta. Outer apophyses arise on each of the six or eight spines at one or multiple levels. An internal spicule with a median bar is six- or eight- rayed; each ray can have three inner apophyses very near the inner surface of the shell." (Won 1997b: 372).

\section{REMARKS}

Dumitrica in De Wever et al. (2001) regards Apophysisphaera Won, 1997 as a junior synonym of Entactinia Foreman, 1963, which itself is a junior synonym to Stigmosphaerostylus Rüst, 1892. The type species, E. profundisulcus Aitchison, 1993 is considered to be a junior synonym of Stigmosphaerostylus ornata (nom. corr. ornatus) Hinde, 1899 (Aitchison \& Stratford 1997: 380).

\section{Astroentactinia Nazarov, 1975}

Astroentactinia Nazarov, 1975b: 82; 1975a: 39 (nomen nudum).

TYPE SPECIES. - Astroentactinia stellata Nazarov, 1975 (Nazarov 1975b: 82, pl. 8, fig. 6).

AgE AND LOCATION OF TYPE MATERIAL. - Upper Devonian, Frasnian stage, Egindinskaya series, Southern Urals, Northern Mugodzhars, Aitpaika River, Russia.

TAXON CODE. -079 .

STATUS. - Junior synonym of Stigmosphaerostylus Rüst, 1892 (by Won 1997a: 340).

DiAGNOSIS. - “ОАна сферическая оболочка с эксцентрично расположенной внутренней спикулой или многогранником от семи и бомее кучей, имеющих апофизы; в диетамьной части образуются основные игпы и внешняя оболочка".

DiAGNOSIS (English translation of Nazarov [1975b] by E. Roden in the rad database microfiche collection of Bill Riedel). - "One spherical shell with an eccentrically located inner spicule or a polyhedron with seven or more rays with apophyses; the basic spines as well as the outer shell develop in the distal part." 


\section{REMARKS}

Won (1997a) considered this genus to be a junior synonym of Entactinia Foreman, 1963. Since Entactinia is a junior synonym of Stigmosphaerostylus Rüst, 1892, by extension $A s$ troentactinia is now a junior synonym of Stigmosphaerostylus.

\section{Belowea Won, 1983}

Belowea Won, 1983: 129.

TYPE SPECIES. - Cromyostylus? variabilis Ormiston \& Lane, 1976 (Ormiston \& Lane 1976: 170, pl. 4, fig. 7-11).

Age AND LOCATION OF TYPE MATERIAL. - Lower Carboniferous, Rheinischen Schiefergebirge, Germany.

TAXON CODE. -080 .

STATUS. - Junior synonym of Entactinosphaera Foreman, 1963 (by Won 1997a: 340, table 2).

Diagnosis. - "Das Skelett besteht aus 2-5, selten nur aus 1 Schale und trägt bis zu 2 Hauptstacheln. Die innerste Schale besteht aus einem eng bis weitmaschigen, hexogonalen bis polygonalen Gitterwerk. Dementgegen sind alle anderen Schalen aus einem engen Gitterwerk aufgebaut und zeigen die, allen Arten der Gattung gemeinsame, gemusterte Oberflächenstruktur. Selten sind innerste Nadeln vorhanden. Wenn das Skelett ein oder zwei gefurchte Hauptstacheln besitzt, sind diese sehr mächtig, zusätzlich können Nebenstacheln entwickelt sein. Die Furchen der Stacheln sind lanzettförmig oder reichen mit konstanter Breite und Tiefe von der Basis bis zur Spitze. Nebenfurchen können an den Stachelbasen vorhanden sein." (Won 1983: 129).

DiagnOSIS (English translation by Jörg Maletz). — " "Test composed of 2-5 shells, rarely only one, and up to two main spines. Inner shell constituted by a lattice with dense to loose hexagonal to polygonal meshes. In contrast, all other shells are formed from a dense meshwork, showing in all species of the genus the same surface structure. Innermost spines rarely present. If the skeletons possess one or two grooved main spines, these are very robust and secondary spines maybe developed. The grooves of the spines can be lanceolate, or straight, with uniform width and depth from the bases to the tips of the spines. Secondary grooves maybe present at the base of the spine."

\section{REMARKS}

Won (1997a: 340, table 2) emended the diagnosis of Entactinosphaera and assigned Belowea as a junior synonym.

\section{Bientactinosphaera Afanasieva, 2000}

Bientactinosphaera Afanasieva, 2000a: 371.

TYPE SPECIES. - Entactinosphaera variacanthina Foreman, 1963 (Foreman 1963: 278, pl. 3, fig. 8, pl. 4, fig. 3a-b).

Age AND location of TYPE MATERIAL. - Upper Devonian, Huron Member, Ohio Shale, USA.

TAXON CODE. - 081 .

Status. - Junior synonym of Trilonche Hinde, 1899 (by Maldonado \& Noble 2010: 84).

DiAGNOSIS. - "Test spherical with two porous shells. Internal centrally located framework takes form of slender six-rayed spicule with rays extended by three-bladed main spines." (Afanasieva 2000a: 371).

\section{REMARKS}

This name was proposed by Afanasieva (2000a) to accommodate 2-shelled species, formerly included in Entactinosphaera Foreman, 1963 although Trilonche Hinde, 1899 encompasses these forms and has priority over Bientactinosphaera.

\section{Bisphaera Won, 1997}

Bisphaera Won, 1997a: 344.

TYPE SPECIES. — Bisphaera solidispinosa Won, 1997 (Won 1997a: 346, pl. 3, fig. 9-11).

Age and location of type Material. - Upper Devonian, Gogo Formation, Canning Basin. Western Australia.

TAXON CODE. - 082 .

STATUS. - Homonym and Junior synonym of Trilonche Hinde, 1899 (by Maldonado \& Noble 2010).

Diagnosis. - "Two spherical latticed shells with six to eight inner spines as well as a six- to eight-rays of an internal spicule with a median bar. No radial beam between the shells." (Won 1997a: 344).

\section{REMARKS}

Won (1997a) emended the diagnosis of Entactinosphaera to exclude two-shelled species, and erected this genus to accommodate the two-shelled forms. The name is a homonym of a fusulinid foraminifer (Bisphaera Birina, 1948), and so the replacement name Duosphaera was proposed (Won 1998). However, the diagnosis is essentially that of Trilonche Hinde, 1899, which has priority (see De Wever et al. 2001: 180).

\section{Borisella Afanasieva, 2000}

Borisella Afanasieva, 2000b: 143.

TYPE SPECIES. — Borisella maksimovae Afanasieva, 1997 (Afanasieva 1997: pl. 2, fig. 14 [nomen nudum]); Afanasieva in Afanasieva \& Mikhailova 1998: pl. 3, fig. 4 (nomen nudum); 2000b: 144, pl. 2, figs 10, 11.

AgE AND LOCATION OF TYPE MATERIAL. - Frasnian (Upper Devonian), Timan-Pechora Province, Russia.

TAXON CODE. -083 .

STATUS. - Valid.

Diagnosis. - "Skeleton spherical with one porous lattice shell. Internal skeleton occupies an eccentric position represented by a slender 6-radiate spicule with a short median rod (up to 8.5 $\mu \mathrm{m})$ continued into six shaft-like principal spines." (Afanasieva 2000b: 143).

Callela Won, 1983

Callela Won, 1983: 133.

TYPE SPECIES. - Callela stellaesimilis Won, 1983 (Won 1983: 135, pl. 2, fig. 9, 10, 14). 
AgE AND LOCATION OF TYPE MATERIAL. - Lower Carboniferous, Rheinischen Schiefergebirge, Germany.

TAXON CODE. - 084 .

STATUS. — Valid.

DiagnOSIS. - "Das Skelett besteht aus einer Schale und 6-14 Stacheln. Die Schale ist doppelschichtig. Die äußere Schicht ist dick, die innere dagegen als sehr feines Gitterwerk kongruent zu den Muri des Gitterwerks der äußeren Schicht ausgebildet. Die Stacheln variieren sehr in ihrer Gestalt, Stärke und Länge. Innennadeln sind vorhanden." (Won 1983: 133).

DiAGNOSIS (English translation by J. P. Caulet - RadWorld database). Test composed of a shell and 6-14 spines. Shell with two layers. External layer thick, internal layer as a very delicate meshwork coinciding with the frame nodules of the meshwork of the external layer. Shapes, sizes and lengths of spines very variable. Inner spines present.

\section{Cancellosphaera Afanasieva, 2000}

Cancellosphaera Afanasieva, 2000c: 34

TYPE SPECIES. — Spongosphaera varia Won, 1997 (Won 1997b: 412, pl. 9, figs 2-9, pl. 15, figs 18-21).

AgE AND LOCATION OF TYPE MATERIAL. - Upper Devonian, Gogo Formation, Canning Basin, Western Australia, Frasnian (Upper Devonian).

TAXON CODE. -085 .

STATUS. - Valid.

DiAGNOSIS. - "Раковина сферическая с двумя оболочками: внешней - решетчатой и внутренней -пористой. Внутренний каркас преАставлен тонкой спикулой, шесть мучей которой расходятся от срединной балки. Продолжением мучей спикулы явАяются основные иглы: трехгранные в межсферном пространстве и конусовидные вне наружной оболочки скелета".

ENGLISH TRANSLATION. - "The shell is spherical with two shells: the external is latticed and the internal is porous. The inner frame is represented by a thin spicules, six rays of which diverge from the middle of the beam. The continuation of the rays are the main spicules Needles are triangular in shape but the space is tapered and the outer shell of the skeleton".

\section{REMARKS}

Afanasieva (2000c) separated the species Spongosphaera varia Won, 1997 from the genus Spongosphaera Won, 1997 to serve as the type species for Cancellosphaera. Spongosphaera is characterized by 2 shells, an inner latticed and outer spongy shell, and it has an internal 6-8 rayed spicule. In contrast, Cancellosphaera is defined as having 2 shells, the outer latticed and the inner porous, and a 6 rayed inner spicule.

Costaentactinia Seo \& Won, 2009

Costaentactinia Seo \& Won, 2009: 67.

TYPE SPECIES. - Costaentactinia foremanae Seo \& Won, 2009 (Seo \& Won 2009: 67, pl. 2, fig. 13-20).

Age and location of TyPe MATERIAL. - Upper Devonian, Huron Member, Ohio Shale, USA.
TAXON CODE. -086 .

STATUS. - Valid.

DiAGNOSIS. - "A single subspherical or subpolyhedral shell with angular meshwork. Outer spines, all or some with tent-like structure at their bases; bars forming the tent-like bases merging with shell wall meshwork as ridges or bars of the meshwork. Eccentric internal spicule, whose rays are connected by a median bar or at a meeting point. Apophyses arising near the distal parts of the rays and joined to the inner surface of the shell wall. Because of the bars around spines and the apophyses, the shell wall thickness varying; the shell wall meshwork between spines in places two-dimensional." (Seo \& Won 2009: 67)

\section{Cyclocarpus Li \& Wang, 1991}

Cyclocarpus Li \& Wang, 1991: 403.

TYPE SPECIES. - Cyclocarpus tubiformis Li \& Wang, 1991 (Li \& Wang 1991: 403, pl. 1, fig. 1-2).

Age and location of type material. - Frasnian, Upper Devonian, Liukiang Formation, Guangxi, China.

TAXON CODE. - 087 .

STATUS. - Nomen dubium (herein).

DiAGNOSIS. - "Three spherical shells; perforate plate wall with fenestrae. Outer and inner shells connected with radial tubes; each tube directed toward the fenestrated wall. No spines on the surface of the outer shell." (Li \& Wang 1991: 403).

\section{REMARKS}

The figured specimen represents a mould, in fact a siliceous crust moulding a probable entactinarian and is indetertminable. See for comparison Dumitrica (1999: 160, pl. 4, figs 6-9).

\section{Druppalonche Hinde, 1899}

Druppalonche Hinde, 1899b: 217.

TyPe SPECIES. - Druppalonche clavigera Hinde, 1899 (Hinde 1899b: 217, pl. 16, fig. 14).

AgE AND location of TYPe MATERIAL. — Upper Devonian, Cornwall, England.

TAXON CODE. - 088 .

STATUS. - Junior synonym of Trilonche Hinde, 1899 (herein).

DiAGNOSIS. - "The test consists of two concentric, elliptical, latticed shells, with three radial spines." (Hinde 1899b: 217).

\section{REMARKS}

The description of Druppalonche Hinde, 1899 is essentially the same as that of Trilonche Hinde, 1899. At the time of Hinde's writing the Mullion Island cherts in Cornwall were regarded as Ordovician whereas the Tamworth Series radiolarian rocks are Devonian. The age of Mullion Island cherts is, however now known to be Devonian based on conodonts reported by Hendriks (1970). 


\section{Duodecimentactinia Won, 1997}

\section{Duodecimentactinia Won, 1997b: 377.}

TYPE SPECIES. - Duodecimentactinia aranea Won, 1997 (Won 1997b: 378, pl. 10, fig. 1-5, pl. 16, fig. 7-9).

Age AND location of TYPE MATERIAL. - Frasnian (Upper Devonian), Gogo Formation, Canning Basin, Western Australia.

TAXON CODE. - 089 .

STATUS. - Valid.

DiAGNOSIS. — "The spongy shell has twelve spines. The external shell wall consists of spongy tissue made up of thin, long, curved entangled thread-like elements. The elements attached directly to the numerous spines are thicker than those between the spines. In the inner part of the shell straight, rarely slightly curved, long threads between spines form a spider web-like structure, but three-dimensional, similar to a spider web. An internal spicule consists of two sets of six very thin rays connected by a median bar. Numerous microthorns are densely developed on every ray." (Won 1997b: 377).

\section{Duosphaera Won, 1998}

Duosphaera Won, 1998: 235.

TYPE SPECIES. - Bisphaera solidispinosa Won, 1997-(Won 1997a: 346, pl. 3, fig. 9-11).

Age and location of type Material. - Frasnian (Upper Devonian), Gogo Formation, Canning Basin, Western Australia.

TAXON CODE. - 090 .

STATUS. - Junior synonym of Trilonche Hinde, 1899a (Dumitrica in De Wever et al., 2001: 180).

DiagnOSIS. — as for Bisphaera Won, 1997.

\section{REMARKS}

Won (1998) introduced Duosphaera as a replacement for Bisphaera, a homonym. Trilonche has priority (see remarks under Bisphaera).

\section{Entactinia Foreman, 1963}

Entactinia Foreman, 1963: 271.

Type sPeCIEs. - Entactinia herculea Foreman, 1963 (Foreman 1963: 271, pl. 1, fig. 3a-d).

Age And location of type Material. - Upper Devonian, Huron Member, Ohio Shale, USA.

TAXON CODE. - 091 .

STATUS. - Junior synonym of Stigmosphaerostylus Rüst, 1892 (by Aitchison \& Stratford 1997: 380).

DiAGNOSIS. - "A single well-developed latticed or spongy shell (sometimes with external spongy material) and an internal sixrayed double spicule more delicate than the main spines." (Foreman 1963: 271).

\section{REMARKS}

Stigmosphaerostylus has priority over Entactinia but the more precise diagnosis of Foreman (1963) was adopted as an emendment by Aitchison \& Stratford (1997: 380). See also Aitchison et al. (1999).

\section{Entactinosphaera Foreman, 1963 sensu Won (1997a)}

Entactinosphaera Foreman, 1963: 274. — Won 1997a: 340.

Thecentactinia Nazarov, 1975b: 71.

Belowea Won, 1983: 129.

Stolbergia Kozur \& Mostler, 1989: 198 (n. syn.)

TYPE SPECIES. - Entactinosphaera esostrongyla Foreman, 1963: 274, pl. 2, fig. 1, pl. 6, fig. 1a-b.

Age and location of TyPe Material. - Upper Devonian, Huron Member, Ohio Shale, USA.

TAXON CODE. - 092 .

STATUS. — Valid.

DiAGNOSIS. - "Two or more, well-developed, spherical or subspherical shells, and an internal, six-rayed double spicule. When secondary spines are present, the six spines developed from the rays of the internal spicule are generally differentiated and recognizable as main spines." (Foreman 1963: 274).

\section{REMARKS}

Won (1997a) restricted this genus to forms with three or more shells. Many two-shelled species originally assigned to Entactinosphaera now reside in Trilonche Hinde, 1899.

\section{Gracilentactinia Kozur \& Mostler, 1989}

Gracilentactinia Kozur \& Mostler, 1989: 192.

TYPe SPECIES. - Gracilentactinia gracilis Kozur \& Mostler, 1989: 192, pl. 6, fig. 7-9, pl. 8, fig. 5.

AgE AND LOCATION OF TYPE MATERIAL. - Sakmarian-Artinskian (Lower Permian), Cis-Urals, Russia.

TAXON CODE. - 093 .

STATUS. — Valid.

DiAgnosis. - "Von einem Spicularsystem in einer winzigen Markschale gehen 6-8 wuchtige scharfkantige Hauptstacheln aus, die zunächst immer breiter, dann wieder schmaler werden. Etwa an ihrer breitesten Stelle zweigen von den Kanten Apophysen ab, die den Ausgangspunkt eines sehr lockeren Schalen-ähnlichen Geflechtes bilden. Von den Kreuzungspunkten der Gitterbalken strahlen nadelförmige Stacheln nach innen, niemals jedoch nach außen.” (Kozur \& Mostler 1989: 192).

Diagnosis (English translation by J. P. Caulet - RadWorld database - modified by Jörg Maletz). — 6-8 strong, sharp-sided main spines that initially widen from their bases and then become progressively thinner towards their distal ends originate from the inner spicule located inside a very small medullary shell. Approximately 
on their widest points, apophyses branch out from the sides of the spines and form the basis of a spongy, shell-like meshwork. From the nodal points of the meshwork, needle-shaped spines are directed inwards, never outwards.

\section{Helioentactinia Nazarov, 1975}

Helioentactinia Nazarov, 1975b: 88; 1975a: 98 (nomen nudum).

TYPE SPECIES. - Entactinosphaera? polyacanthina Foreman, 1963 (Foreman 1963: 280, pl. 4, fig. 6, pl. 6, fig. 11).

Age AND location of TYPE MATERIAL. - Upper Devonian, Huron Member, Ohio Shale, USA.

TAXON CODE. - 094 .

StATUS. - Nomen dubium (by Won et al. 1997a: 350, 351).

DiAGNOSIS. - “Аве сферические решетчатые оболочки с многочисленными внешними иглами, возникающими от концов многокучевой спикулы или многогранными, занимающими центрамьное мибо эксцентричное положение во внутренней оболочке". (Nazarov 1975b: 88)

DiAGNOSIS (English translation of Nazarov [1975b] by E. Roden in the rad database microfiche collection of Bill Riedel). - "Two spherical latticed shells with numerous outer spines, extending from the ends of the multirayed spicule or polyhedron located centrally or eccentrically in the inner shell."

\section{Holdisphaera Kozur \& Mostler, 1989}

Holdisphaera Kozur \& Mostler, 1989: 186.

Type sPeCIES. - Holdisphaera furutanii Kozur \& Mostler, 1989 (Kozur \& Mostler 1989: 187, pl. 10, fig. 9 10, pl. 11, fig. 2, 4).

AGE AND LOCATION OF TYPE MATERIAL. — Sakmarian-lower Artinskian (Lower Permian), Cis-Urals, Russia.

TAXON CODE. - 095 .

STATUS. — Valid.

Diagnosis. — “Äußere Schale zweischichtig, kugelförmig. Die äußere Schicht weist sehr kleine bis kleine, rundliche bis ovale unregelmäßige Poren auf. Ihre Oberfläche ist entweder glatt oder durch winzige Erhebungen oder Knötchen auf den Gitterkreuzungspunkten uneben. Die innere Schicht besitzt etwas größere Poren. Von dieser inneren Schicht verlaufen zahlreiche Stützbalken zur nächsten Schale, die stets in kurzem Abstand folgt. Diese Schale ist einfach oder angedeutet zweischichtig. Ihre Poren sind klein und unregelmäßig oder mittelgroß und regelmäßig. Die in großem Abstand folgende innerste Schale ist klein und weist kleine bis mittelgroße Poren auf. Sie ist mit der zweiten Schale durch 6 (?) Hauptstacheln verbunden, die sich nicht bis zur äußeren Schale fortsetzen und nach innen in ein Spicularsystem auslaufen.” (Kozur \& Mostler 1989: 186).

DiAgnosis (English translation by J. P. Caulet - RadWorld database - modified by Jörg Maletz). — External shell spherical, two-layered. External envelope with irregular, circular to oval, very small to small pores. Surface smooth, or rough with minute elevations, or nodes at nodal frames. Inner envelope with somewhat larger pores. Numerous rays extend from this inner envelope to the next shell at a short distance. This shell is simple, or maybe shows indications of two layers. Its pores are small and irregular, or of middle size and regular shape. The innermost shell, separated by a large interval, is small with small to middle-sized pores. It is linked to the second shell by 6 (?) main spines that do not continue up to the external shell but produce an inner spicule.

\section{Inaequalientactinia Won, 1991}

Inaequalientactinia Won, 1991: 100.

TyPE SPECIES. — Inaequalientactinia typica Won, 1991 (Won 1991: 103, pl. 1, fig. 1-3).

Age AND location of tyPe MATERIAL. - Lower Carboniferous, western Germany.

TAXON CODE. - 096 .

STATUS. - Junior synonym of Stigmosphaerostylus Rüst, 1892 (by Won 1997a).

DiAGNOSIS. - "A single latticed shell with hexagonal meshwork with general one stronger spine and five weaker spines and an internal six-rayed double spicule." (Won 1991: 100).

\section{REMARKS}

Won (1997a) synonymized Inaequalientactinia Won, 1991 with Entactinia Foreman, 1963, which itself is a junior synonym of Stigmosphaerostylus Rüst, 1892 (see above).

\section{Involutentactinia Jones \& Noble, 2006}

Involutentactinia Jones \& Noble, 2006: 296.

TYPE SPECIES. - Involutentactinia eccentra Jones \& Noble, 2006 (Jones \& Noble 2006: 297, pl. 1, fig. 8-11, pl. 6, fig. 1-3).

AgE AND LOCATION OF TYPE MATERIAL. - Lower Wenlock, uppermost Lower Silurian (C. permeri-M. opimus graptolite zones, Sheinwoodian), Cape Phillips Formation, Nunavut, Canada.

TAXON CODE. -097 .

STATUS. - Valid.

DiAGNOSIS. - " "Spherical to subspherical shell consisting of three to four layers of weakly spiraliform labyrinthine material. Six-rayed bar-centered spicule occurs eccentrically within the inner shell. Apophyses on rays are present at inner spine/whorl intersections." (Jones \& Noble 2006: 296).

\section{Kashiwara Sashida \& Tonishi, 1985}

Kashiwara Sashida \& Tonishi, 1985: 14.

TyPE SPECIES. - Kashiwara magna Sashida \& Tonishi, 1985 (Sashida $\&$ Tonishi 1985: 15, pl. 5, fig. 4-12).

Age and location of type material. - Upper Permian (Guadalupian or younger), Itsukaichi, Tokyo Prefecture, Central Japan.

TAXON CODE. -098 .

STATUS. - Valid. 
DiagnOSIS. - "Palaeoactinommids" consists of two spherical lattice shells with four main spines. Four primary radial beams connecting with the inner and outer shells with the main spines". (Sashida \& Tonishi 1985: 15).

\section{REMARKS}

"Kashiwara n. gen. is characterized by large (410-450 $\mu \mathrm{m})$ and thick outer shell with large subcircular pores and the four tetrahedral main spines." (Sashida \& Tonishi 1985: 15)

\section{Magnentactinia Won, 1997}

Magnentactinia Won, 1997a: 366.

TYPe SPECIES. — Magnentactinia fragilis Won, 1997 (Won 1997a: 366, pl. 6, fig. 1-2).

Age AND location of TYPE MATERial. - Frasnian (Upper Devonian), Gogo Formation, Western Australia.

TAXON CODE. - 99 .

STATUS. — Valid.

Diagnosis. - "The very large single spherical shell having a very open, large-pored framework and a six-rayed internal spicule with a median bar. Sometimes secondary struts subdividing each mesh opening present. Three meshwork bars arising on each spine thicker than those making up the remainder of the shell." (Won 1997a: 366).

\section{Magnisphaera Won, 1997}

Magnisphaera Won, 1997a: 366.

TYPE SPECIES. - Magnisphaera gigantea Won, 1997 (Won 1997a: 368, pl. 6, fig. 3-5).

Age AND LOCATION OF TYPE MATERIAL. - Frasnian (Upper Devonian), Gogo Formation, Western Australia.

TAXON CODE. - 100 .

STATUS. - Valid.

DiAGNOSIS. - "A very large skeleton with two shells; the outer shell consisting of a polygonal (four-to eight-sided) or irregular lattice that is extremely loose, completely two-dimensional, partly or wholly three-dimensional, or incompletely latticed; straight or drooping bars forming meshwork; an irregularly latticed inner shell; the eight-rayed internal spicule with a median bar, no inner apophyses, with or without outer apophyses." (Won 1997a: 366).

\section{Meschedea Won, 1983}

Meschedea Won, 1983: 154.

TYPE SPECIES. - Meschedea pyramispinosa Won, 1983 (Won 1983: 154, pl. 4, fig. 5-7).

AgE AND LOCATION OF TYPE MATERIAL. - Lower Carboniferous, Rheinischen Schiefergebirge, Germany.

TAXON CODE. - 101.
STATUS. — Junior synonym of Pluristratoentactinia Nazarov, 1981 (herein).

DiAGNOSIS. - "Das sphäroidale Skelett besteht aus 3 Schalen, die von einem Gitterwerk gebildet werden. Der Abstand zwischen den beiden äußeren Schalen ist geringer als der zwischen der mittleren Schale und der innersten Schale. Die Oberfläche des Skeletts weist zahlreiche, kleine, runde, dichtstehende Poren auf. Die 3 Schalen sind durch innere Stacheln und zahlreiche Dornen miteinander verbunden. Die Stachelzahl auf der Oberfläche variiert. Im Vergleich zu anderen Gattungen ist der Durchmesser der innersten Schale im Verhältnis zur Skelettgröße recht groß.“ (Won 1983: 154).

DiAgNosis (English translation by J. P. Caulet - RadWorld database - modified by Jörg Maletz). - Spherical test with three lattice shells. The interval between the two external shells is smaller than the interval between the median and medullary shells. Surface of the shell with many small, circular, closely distributed pores. The three shells are linked by internal spines and numerous thorns. Number of external spines variable. Compared to other genera, the diameter of the medullary shell, related to the size of the test, is very large.

\section{REMARKS}

Description falls within the morphology of Pluristratoentactinia, which has priority.

\section{Microporosa Afanasieva \& Amon, 2016}

Microporosa Afanasieva \& Amon, 2016: 211.

TyPe SPECIES. - Triposphaera permica Kozur \& Mostler, 1989 (Kozur \& Mostler 1989: 191, pl. 2, fig. 2, 3, 8, 9, pl. 4, fig. 4, 5, pl. 5, fig. 3-5).

Age and location of type material. - Lower Permian, CisUrals, Russia.

TAXON CODE. -102 .

STATUS. - Valid.

DiAGNOSIS. - "Skeleton spherical with two porous shells. External shell formed of fine-porous skeletal tissue, internal shell relatively coarse-porous. Internal skeleton formed of 6-ray spicule, rays of which continued by massive three-bladed main spines with threebladed-shaped base section. Internal rod-shaped spines diverging from nodes of interpore bars of internal sphere and sometimes continued by external by-spines." (Afanasieva \& Amon 2016: 211).

\section{Moskovistella Afanasieva, 2000}

Moskovistella Afanasieva, 2000b: 135; 1997: 255 (nomen nudum).

TYPE SPECIES. - Moskovistella octoradiata Afanasieva, 2000 (Afanasieva 2000b: 136, pl. 1, figs 8, 9).

Age and location of type MATERIAL. - Frasnian (Upper Devonian), Timan-Pechora Province, Russia.

TAXON CODE. - 103 .

STATUS. — Valid.

DIAGNOSIS. - "Skeleton spherical with one porous lattice shell. Internal skeleton occupying central position, represented by a slender 8 -radiate spicule with a long median rod (up to $15.5 \mu \mathrm{m}$ ) continued into eight 3-sided (more rarely shaft-like) principal spines." (Afanasieva 2000b: 135). 
Multientactinia Won, 1997

Multientactinia Won, 1997b: 378.

TYPE SPECIES. - Multientactinia inconstans Won, 1997 (Won 1997b: 379, pl. 11, fig. 1-8).

Age AND location of TyPe MATERial. - Frasnian (Upper Devonian), Gogo Formation, Canning Basin, Western Australia.

TAXON CODE. -104 .

STATUS. - Valid.

DiAGNOSIs. - "The spherical spongy shell has twelve, fourteen, sixteen (?), eighteen, or twenty rod-like outer spines that are unevenly distributed because of the eccentric position of the spicule's median bar. Two sets of five, six, seven (?), eight, or nine rays arise from two points on a bar that forms the axis of the internal spicule, and the bar passes through the shell wall. The median bar is long and is the central part of the axis bar be-tween the two points from which the rays arise. The distal parts of the axis bar beyond the two points of ray origin form two rays of the multi-rayed internal spicule and two of the numerous outer spines. The internal spicule is exceptionally thick, nearly as thick as the outer spines. Apophyses or traces of apophyses on each ray lie very near the inner surface of the shell." (Won 1997b: 378).

\section{Munzuwonella Afanasieva, 2009}

Nomem novum for Wonella Afanasieva, 2000.

TYPE SPECIES. - Retentactinia impedita Won, 1997 (Won 1997b: 385, pl. 6, fig. 14, 15, 18-20).

Age And location of type MATERIAL. - Frasnian (Upper Devonian), Gogo Formation, Canning Basin, Western Australia.

TAXON CODE. -105 .

STATUS. - Valid.

DiAgNOSIS. - as for Wonella Afanasieva, 2000.

\section{Ornatoentactinia Afanasieva, 2000}

Ornatoentactinia Afanasieva, 2000a: 373.

TYPE SPECIES. - Ornatoentactinia solita Afanasieva, 2000 (Afanasieva 2000a: 374, pl. 2, figs 11-14).

AgE AND location of TYPE MATERIAL. — Upper Devonian, Ukhta River, Timan-Pechora Province, Russia.

TAXON CODE. - 106 .

STATUS. - Junior synonym of Trilonche Hinde, 1899 (herein).

DiAGNOSIS. - " "Test spherical with two porous shells. Internal sub centrally located framework takes form of slender six-rayed spicule with rays extended by three bladed main spines. External shell includes system of tangential elements forming cellular structure." (Afanasieva 2000a: 373).

\section{REMARKS}

The diagnosis is essentially the same as that for Trilonche, which has priority.
Palaeopentactinorbis Kozur \& Mostler, 1989

Palaeopentactinorbis Kozur \& Mostler, 1989: 195.

TYPE SPECIES. - Palaeopentactinorbis longispinosa Kozur \& Mostler, 1989 (Kozur \& Mostler 1989: 195, pl. 13, fig. 1, 2, 8, 9).

Age and location of type Material. - Sakmarian, Lower Permian, Cis-Urals, Russia.

TAXON CODE. -107.

STATUS. - Junior synonym of Pentactinorbis Dumitrica, 1978 (herein).

DiAGNOSIS. — “Äußeres Gitter sehr grobporig, sphärisch, mit zahlreichen langen, nadelförmigen, runden Stacheln. Das innere Gitter besteht aus wenigen, aber kräftigen Balken, die von einer exzentrisch gelegenen Pentactine mit 4 Basalstacheln und 1-2 Apicalstacheln ausgehen.” (Kozur \& Mostler 1989: 195).

DiAgnosis (English translation by J. P. Caulet - RadWorld database). - "External lattice shell coarsely porous, spherical, with numerous long, needle-shaped, spines having a circular cross-section. Inner lattice shell with rare, but strong bars growing eccentrically from a pentactine spicule constituted by 4 basal spines and 1-2 apical spines."

\section{REMARKS}

The type species of the genus Palaeopentactinorbis seems to be nothing else than a species of the Middle to Late Triassic genus Pentactinorbis Dumitrica, 1978, from which it only differs in having long spines. Kozur \& Mostler (1989) wrote that the Triassic species have a much larger pentactine with regular arches. The regularity of the inner arched bars of the Triassic species, considered as distinctive generic characters, is resulted by their lateral positions, whereas the Permian holotype has a position that is difficult to define.

\section{Palaeoxyphostylus Won, 1983}

Palaeoxyphostylus Won, 1983: 155.

TYPe SPECIES. - Palaeoxyphostylus variospina Won, 1983 (Won 1983: 156, pl. 8, fig. 1-4, 6-22).

Age And LOCATION OF TYPE MATERIAL. - Lower Carboniferous, Rheinischen Schiefergebirge, Germany.

TAXON CODE. -108.

STATUS. — Junior synonym of Stigmosphaerostylus Rüst, 1892 [by Won, 1997a].

DiAgNOSIS. - "Das Skelett besteht aus einer sphäroidalen Schale mit meist 2 Polstacheln. Das Gitterwerk der Schale ist in der Regel mit erhöhten hexagonalen bis subhexagonalen Muri ausgestattet. Es können insgesamt bis zu sechs Stacheln vorhanden sein, die gleich oder auch unterschiedlich lang sind. 6 innere Skelettnadeln sind vorhanden." (Won 1983: 155).

DiAgNosis (English translation by J. P. Caulet - RadWorld database). - "Spherical shell usually with two polar spines. Meshwork of this shell usually constituted by hexagonal to sub-hexagonal pores. Up to 6 spines of similar, or variable, lengths can be observed. Internal skeleton also with 6 inner spines". 


\section{REMARKS}

Won (1997a) synonymized Palaeoxyphostylus Won, 1983 with Entactinia Foreman, 1963, which itself is a junior synonym of Stigmosphaerostylus Rüst, 1892 (see above).

\section{Paleoxiphosphaera Nazarov, 1973}

Paleoxiphosphaera Nazarov, 1973: 9.

TyPe SPECIES. - Paleoxiphosphaera erbiensis Nazarov, 1973 (Nazarov 1973: 9, 10, pl. 1, fig. 4).

Age ANd location of type MATERial. - Lower Cambrian, Atdabanskij stage. Kuznetskij Alatau (Batenevskij ridge, $3 \mathrm{~km}$ to the north of Bograd village).

TAXON CODE. -109 .

STATUS. - Nomen dubium.

DiAGNOSIS. - "Раковника сферическая, толстостенная с двумя полярньми иглами, расположенными основаниями по одной оси, по свободные концы накмонены от основания под угАом к поверхности сферы”.

DiAgNosis (English translation by J. P. Caulet - Radworld database). - "Shell spherical, thick-walled with two polar spines distributed along one axis, but their free ends are related to their bases under an angular enlargement to the surface of the shell."

\section{REMARKS}

The type species was tentatively reassigned as Entactinia? erbiensis in Nazarov (1975b: 56), yet the inner structure was not preserved, leaving its reassignment in question.

\section{Paratriposphaera Kozur \& Mostler, 1989}

Paratriposphaera Kozur \& Mostler, 1989: 187.

TYPE SPECIES. - Entactinosphaera strangulata Nazarov \& Ormiston, 1985 (Nazarov \& Ormiston 1985: 20, pl. 2, fig. 1-2).

Age AND location of TyPe Material. - Artinskian (Lower Permian), Don village, Ural River, Southern Urals, Russia.

TAXON CODE. -110 .

STATUS. — Valid.

DiAgNOSIS. - "Spicularsystem Balken-zentriert, mit 6 Spiculae, die von den Enden des Median-Balkens ausgehen. Sie laufen in die äußeren dreikantigen Hauptstacheln, von denen aber meist nur 2 polare Stacheln kräftig ausgebildet sind. Die anderen Hauptstacheln können völlig fehlen, wobei sie schon außerhalb der Markschale nicht mehr in Erscheinung treten. Mitunter ist auch nur ein Hauptstache kräftig ausgebildet, und die anderen 5 sind wesentlich kleiner. Sie ist durch die inneren dreikantigen Verlängerungen der Hauptstacheln und durch zahlreiche runde nadelförmige Stützbalken mit der kugelförmigen äußeren Schale verbunden. Die äußere Schale besteht aus einer perforierten Schale mit rundlichen Poren und einer äußeren Schale aus kräftigen Balken, die ein lockeres Gittergeflecht bilden.” (Kozur \& Mostler 1989: 187).

DiAgnOSIS [English translation by J. P. Caulet RadWorld databasemodified by Jörg Maletz]. — "Bar-centered spicule with 6 rays growing from the ends of the median bar. Rays extending into 6 external three-sided main spines from which two are, most of the time, strong polar spines. Other main spines may be completely lacking, in which case they do not protrude outside of the internal shell. Sometimes, only a single main spine is strongly developed, the five other ones being considerably smaller. This medullary shell is connected to the spherical outer cortical shell through the inner parts of the threesided main spines as well as through many bars that are circular in cross-section and needle-shaped. The cortical shell is composed of a perforated layer with circular pores surrounded by an outer layer of robust bars, forming a spongy meshwork."

\section{Perforentactinia Jones \& Noble, 2006}

Perforentactinia Jones \& Noble, 2006: 298.

TyPe SPECIES. - Perforentactinia excepta Jones \& Noble, 2006 (Jones \& Noble 2006: 298, pl. 3, fig. 1-5, pl. 6, fig. 5).

AgE AND LOCATION OF TYPE MATERIAL. - Lower Wenlock, uppermost Lower Silurian (C. permeri-M. opimus graptolite zones, Sheinwoodian), Cape Phillips Formation, Nunavut, Canada.

TAXON CODE. - 111 .

STATUS. - Valid.

DiAGNOSIS. - "Single large, latticed to irregularly porous medullary shell with large sub rounded pores. Outer apophyses on rays may form partial or complete cortical shell. Eight-rayed bar-centered spicule occurs eccentrically within medullary shell. Primary spines rod-shaped." (Jones \& Noble 2006: 298).

\section{Plenoentactinia Won, 1997}

Plenoentactinia Won, 1997b: 381.

TYPE SPECIES. - Plenoentactinia sexangula Won, 1997 (Won 1997b: 382, pl. 3, fig. 1-4, pl. 15, fig. 13).

Age AND location of tyPe MATERial. - Frasnian (Upper Devonian), Gogo Formation, Canning Basin, Western Australia.

TAXON CODE. -112 .

STATUS. - Valid.

DiAGNOSIS. - "The spherical shell ranges from compact and nonlayered spongy to multi-layered and having concentric, radial, and subtetragonal structure in its cross section. The surface layer typically consists of spongy tissue. Six or numerous outer spines are extension of a six- to eight-rayed internal spicule with a median bar. Traces of apophyses are generally present." (Won 1997b: 381).

\section{Plenosphaera Park \& Won, 2012}

Plenosphaera Park \& Won, 2012: 56 (nomen novum for Spongosphaera Won, 1997).

TYPE SPECIES. - Spongosphaera grandispongiosa Won, 1997 (Won 1997b: 410, pl. 9, figs 15-20).

Age and location of type MATERIAl. - Frasnian (Upper Devonian), Gogo Formation, Canning Basin, Western Australia.

TAXON CODE. -113

STATUS. - Valid. 
DiAGNOSIS. - "A skeleton consists of two shells, the outer varying from a thick spongy tissue to one thin layer of irregular meshwork, the inner a latticed shell surrounding a six- to eight-rayed internal spicule with a median bar. Outer apophyses are clearly to faintly developed or modified or absent. No inner apophyses are present."(Park \& Won 2012: 56).

\section{REMARKS}

Park \& Won (2012) proposed Plenosphaera as a replacement name for Spongosphaera Won 1997, which is a homonym (see remarks under Spongosphaera).

\section{Pluristratoentactinia \\ Nazarov in Nazarov, Tkachenko \& Shulgina, 1981}

Pluristratoentactinia Nazarov in Nazarov, Tkachenko \& Shulgina, 1981: 86 .

Meschedea Won, 1983: 154 (n. syn.)

TYPe SPECIES. - Pluristratoentactinia conspissata Nazarov in Nazarov, Tkachenko \& Shulgina, 1981 (Nazarov et al. 1981: 87, pl. 2, figs 4-7).

AgE AND LOCATION OF TYPE MATERIAL. - Upper Devonian (Famennian) Duksundinsk Suite, Kolyma River area, Russia.

TAXON CODE. -114

STATUS. - Valid.

DIAGNOSIS. - Entactiniidae, “обладающие пористой внутренней и зубчатой внешней оболочками, межАу которыми располагается от Авух до четырех сближенных промежуточных сфер. Эти сферы, вероятно, являются дифференцированным губчатым слоем. Внутренняя шестилучевая спикула соединяется с проходящими через все сферы радиальными перекладинами, которые непосредственно, переходят в основные иглы." (Nazarov in Nazarov et al. 1981: 86).

DiAGNOSIS (English translation). — "Entactiniidae having latticed inner and outer shells, between which is located an intermediate area ( 2 to 4 contiguous medular spheres). This area is likely to be a differentiated spongy layer. Internal six-rayed spicule with rays that connect directly to main spines".

\section{REMARKS}

Won (1997a) synonymizes this genus with Entactinosphaera, however the differentiated spongy layer makes it distinct.

\section{Polyedroentactinia Kozur \& Mostler, 1989}

Polyedroentactinia Kozur \& Mostler, 1989: 194.

Polydroentactinia - Kozur \& Mostler 1989: 194 (misspelling in the title of genus description).

TyPe SPECIES. - Polyedroentactinia cisuralica Kozur \& Mostler, 1989 (Kozur \& Mostler 1989: 194, pl. 12, fig. 4-7, pl. 13, fig. 3).

Age and location of type material. - Lower Permian, CisUrals, Russia.

TAXON CODE. -115 .

STATUS. — Valid.
Diagnosis. - "Die polyeedrische Schale besteht aus einem sehr groben Balkengeflecht, das viereckige bis sechseckige, selten auch dreieckige ebene Flächen abgrenzt, die ein sehr grobes Maschengeflecht mit sehr unterschiedlich großen Poren aufweisen. Die Zahl der nadelförmig schlanken, aber trotzdem dreikantigen Hauptstacheln beträgt 7-10. Das kräftige Spicularsystem ist zentral gelegen. Von einem Medianbalken gehen insgesamt 7-10 kräftige Spiculae aus, die in die Hauptstacheln laufen. Meist gehen von einem Ende des Medianbalkens 4, am anderen Ende 3-4 Spiculae aus." (Kozur \& Mostler 1989: 194).

DiAGNOSIS (English translation by J. P. Caulet RadWorld database modified by Jörg Maletz). — "Polyedral shell with a coarse meshwork of quadrangular, hexagonal, or rarely triangular, flat areas, forming a very large meshwork with irregular pores of highly variable size. 7-10 slender, needle-shaped main spines with three-bladed crosssection. Usually 4 rays at one end of the median bar and 3-4 rays at the other end."

\section{REMARKS}

Nestell \& Nestell (2010: 21, 22), consider this a monotypic genus within their new subfamily Polyedroenctaciniinae Nestell \& Nestell, 2010, which they place within the family Orosphaeridae, yet they note a 6 to 8 rayed bar-centered spicule in one of their species, which would indicate placement in the entactinarians.

\section{Provisocyntra Nazarov \& Ormiston, 1987}

Provisocyntra Nazarov \& Ormiston, 1987: 68.

TYPE SPECIES. - Provisocyntra cassicula Nazarov \& Ormiston, 1987 (Nazarov \& Ormiston 1987: 72, pl. 1, fig. 1-6, pl. 2, fig. 7).

AgE AND LOCATION OF TYPE MATERIAL. - Lower Carboniferous (Siphonodella isosticha Zone), Lodgepole Formation, North Dakota, USA.

TAXON CODE. -116 .

STATUS. - Valid.

DiAGNOSIS. - "Entactiniidae with radially differentiated spongy layer and numerous main spines of rod-like form merging with very fine rays of an internal framework, whose structure is not entirely clear. It is likely eccentrically situated inside a small porous sphere." (Nazarov \& Ormiston 1987: 68)

\section{REMARKS}

Nazarov \& Ormiston (1987) interpreted a spicule to be in the center, but it might be a proloculus, which would warrant its removal from the Entactinaria.

\section{Radiobisphaera Won, 1997}

Radiobisphaera Won, 1997a: 350.

TYPE SPECIES. - Radiobisphaera variantia Won, 1997 (Won 1997a: 356, pl. 5, fig. 1-7, 9-11).

Age AND location of type MATERial. - Frasnian (Upper Devonian), Gogo Formation, Western Australia.

TAXON CODE. - 117 .

STATUS. - Valid. 
DiAGNOSIs. - " "Two latticed shells, an outer and inner shell; generally numerous outer spines, one or six of these commonly are much or slightly stronger than the others; with six inner spines which are the continuations of the six rays of an internal spicule with a median bar; radial beams arising from the surface of the inner shell and commonly protruding out of the outer shell; no apophyses present." (Won 1997a: 350).

\section{Retentactinia Won, 1997}

Retentactinia Won, 1997b: 383.

Type sPeCIES. - Retentactinia repleta Won, 1997 (Won 1997b: 390, pl. 7, fig. 9-15, pl. 12, fig.1-4).

Age AND location of TyPe MATERIAL. - Frasnian (Upper Devonian), Gogo Formation, Canning Basin, Western Australia.

TAXON CODE. -118

STATUS. - Valid.

DiAGNOSIS. - "The single spherical shell is spongy; a basal layer is not present. Three to four apophyses arise from every ray of an internal spicule at one to several levels. They or their branches join directly, or through one or more intervening bars, to neighboring apophyses and form a complex network structure (N-frame). The N-frame is represented by a subcircular to sub rhombohedral frame (R-frame). The internal spicule with a median bar is six-rayed." (Won 1997b: 383).

\section{Retisphaera Won, 1997}

Retisphaera Won, 1997b: 390.

TYPE SPECIES. - Spongentactinia concinna Aitchison, 1993 (Aitchison 1993b: 116, pl. 6, fig. 10).

Age ANd location of type Material. - Frasnian, (Upper Devonian), Gogo Formation, Canning Basin, western Australia.

TAXON CODE. - 119 .

STATUS. - Valid.

DiAGNOSIS. - "The skeleton has two shells, the outer spongy, and the inner, bubble-like and loosely but complexly interwoven, or latticed but the lattice not completely two-dimensionally woven. Outer apophyses are weakly developed or remain as traces. Inner apophyses either form an $\mathrm{N}$-frame or remain as traces on some rays. Radial beams are variable in number; many are furcated or have branches. A six-rayed internal spicule with a short median bar is located eccentrically." (Won 1997b: 390).

\section{Sinosphaera Feng in Feng, Gu, Jiang \& Jin, 2004}

Sinosphaera Feng in Feng, Gu, Jiang \& Jin, 2004: 137.

Type SPECIES. - Sinosphaera spinosa Feng in Feng, Gu, Jiang \& Jin, 2004 (Feng et al. 2004: 137, pl. 1, fig. 1-10, pl. 2, fig. 1-7, pl. 3, fig. 9-12).

AgE AND LOCATION OF TYPE MATERIAL. - Upper Changxingian (uppermost Permian), Dongpan section, Dalong Formation, Southern China.

TAXON CODE. -120 .
STATUS. - Valid.

DiAGNOSIs. - "Test consists of a spherical to subspherical, doublelayered cortical shell. Both layers are spongy and connected by numerous beams. The outer layer is thicker than the inner one. Pores on both layers are irregularly arranged. Medullary shell and internal spicule are absent." (Feng in Feng et al. 2004: 137).

\section{Spongentactinia Nazarov, 1975}

Spongentactinia Nazarov, 1975b: 75.

TYPE SPECIES. - Spongentactinia fungosa Nazarov, 1975 (Nazarov 1975b: 75, pl. 11, fig. 6).

Age AND LoCATIOn Of TYPE MATERIAL. - Upper Devonian, Frasnian stage, Egindtnskaya series, Southern Urals, Northern Mugodzhars, Aitpaika River, Russia.

TAXON CODE. -121 .

STATUS. - Valid.

DIAGNOSIS. — "Внешняя оболочка раковины губчатая, внутренняя решетчатая, заключающая внутреннюю четырех - шестилучевую спикулу. Внутренняя оболочка соприкасается с губчатым споем или находится на некотором расстоянии от него" (Nazarov 1975b).

DiAGNOSIS (English translation of Nazarov [1975b] by E. Roden - in the rad database microfiche collection of Bill Riedel). - The outer shell of the skeleton is spongy, the inner shell is latticed and includes the inner four- to six-rayed spicule. The inner shell is adjacent to the spongy layer or lies at a certain distance from it.

\section{REMARKS}

This species differs from Tetrentactinia Foreman, 1963 by the occurrence of an internal latticed shell. Apparently, to this genus can be related Entactinia spongites Foreman, 1963, E. somphorohis Foreman, 1963, E. exilispina Foreman, 1963, and E. manalloea Foreman, 1963, that have a thick spongious layer on top of a thin latticed base, as well as Entactinosphaera? diplostraca Foreman, 1963 with an internal latticed shell slightly separated from the spongious layer can be related to this genus.

\section{Spongosphaera Won, 1997}

Spongosphaera Won, 1997b: 410.

TYPE SPECIES. - Spongosphaera grandispongiosa Won, 1997 (Won 1997b: 410, pl. 9, fig. 15-20).

TAXON CODE. -122 .

STATUS. - Homonym.

DiAGNOSIS. — "The skeleton consists of two shells, the outer spongy, the inner a latticed shell, and a six- to eight-rayed internal spicule with a median bar. No inner apophyses are present, but outer apophyses are clearly to faintly developed." (Won 1997b: 410).

\section{REMARKS}

This is a homonym for the Holocene radiolarian Spongosphaera Ehrenberg, 1847. Plenosphaera Park \& Won, 2012 is the replacement name. 


\section{Staurodruppa Hinde, 1899}

Staurodruppa Hinde, 1899a: 51.

Type SPECIES. - Staurodruppa praelonga Hinde, 1899 (Hinde 1899a: 51, pl. 9, fig. 6).

AgE AND LOCATION Of TYPE MATERIAL. - Frasnian (Upper Devonian), Yarrimie Formation, New England Orogen, NSW, Australia.

TAXON CODE. -123

STATUS. - Junior synonym of Trilonche Hinde, 1899 (by Aitchison \& Stratford 1997).

DIAGNOSIS. — "The test consists of two concentric latticed ellipsoids, cortical and medullary, with four radial spines, disposed crosswise in two axes, but not always at right angles. The radial spines may all be similar, or those of the same axis may be similar; but, owing to the imperfect preservation in the fossil forms, this feature can seldom be ascertained with certainty. This genus corresponds with Staurolonche, Haeckel, and Staurolonchidium, Haeckel, in the Sphaeroidea." (Hinde 1899a: 51).

\section{Stigmosphaerostylus Rüst, 1892 sensu Foreman (1963)}

Stigmosphaerostylus Rüst, 1892: 142. — Foreman 1963: 271.

Entactinia Foreman, 1963: 271.

Paleoxiphosphaera Nazarov, 1973: 9.

Astroentactinia Nazarov, 1975a: 82.

Palaeoxyphostylus Won, 1983: 155.

Inaequalientactinia Won, 1991: 100.

Apophysisphaera Won, 1997b: 372.

TYPE SPECIES. - Stigmosphaerostylus notabilis Rüst, 1892 (Rüst 1892: 142, pl. 10, fig. 2).

Age AND LOCATION OF TYPE MATERIAL. - Lower Carboniferous Kieselschiefer, Harz Mountains, Germany.

TAXON CODE. -124 .

STATUS. — Valid.

Diagnosis. - "Schale eine einfache Gitterkugel mit zwei freien gleichen Polarstacheln und von der Innenwand der Schale ausgehenden Radialstäben.” (Rüst 1892: 142).

DiAgNosis (English translation by J. P. Caulet - RadWorld database). - "Simple, spherical, lattice shell with two similar free polar spines and radial rays emanating from the inner wall of the shell."

\section{REMARKS}

The more precise diagnosis of the junior synonym Entactinia Foreman, 1963 is followed "A single well-developed latticed or spongy shell (sometimes with external spongy material) and an internal six-rayed double spicule more delicate than the main spines." (Foreman 1963: 271).

\section{Stolbergia Kozur \& Mostler, 1989}

Stolbergia Kozur \& Mostler, 1989: 198.
TYPE SPECIES. - Eostylodictya speculum Won, 1983 (Won 1983: 152, pl. 3, fig. 1-2, pl. 14, fig. 4, text-fig. 5d-g).

Age AND LOCATION OF TYPE MATERIAL. - Lower Carboniferous, Rheinischen Schiefergebirge, Germany.

TAXON CODE. -125 .

STATUS. - Junior synonym of Entactinosphaera Foreman, 1963 (herein).

DiAGNOSIS. - "Der äußere Habitus des Skelettes entspricht einer schwach bikonvexen Scheibe. Einschließlich der Markschale treten 1-2 geschlossene Zentralschalen auf, die von 5-7 Reifenschalen umgeben sind, die nur im äquatorialen Bereich ausgebildet sind, wobei auf der Seite des Hauptstachels weniger Schalensegmente vorhanden sind. Markschale sehr groß, hohl, mit 4(6?) Spiculae, die in aufeinander senkrecht stehenden Achsen angeordnet sind, sich aber anscheinend im Zentrum nicht vereinigen. Von der Markschale gehen zahlreiche, dicht nebeneinander liegende radiale nadelförmige Stacheln aus, welche die einzelnen Schalen, die durchwegs in geringem Abstand aufeinander folgen, miteinander verbinden. In der Äquatorialebene können Radialstacheln auftreten. Ein einzelner, sehr kräftiger dreikantiger Hauptstachel ist ausgebildet." (Kozur \& Mostler 1989: 198).

DiAGNOSIS (English translation by J. P. Caulet RadWorld database modified by Jörg Maletz). - Test as a thin biconvex disc. Aside the medullary shell, 1-2 closed central shells surrounded by 5-7 annular shells, only organized in the equatorial plane, although thin shell fragments can occur on the side of the main spine. Medullary shell very large, hollow, with 4 (6?) spicules that are distributed following axes perpendicular to each other, but apparently not joining at the centre. Numerous, closely spaced needle-like radial spines originate from the medullary shell and connect the densely spaced outer shells. Some radial spines may be present in the equatorial plane. A single, very robust, three-bladed main spine is present.

\section{REMARKS}

The diagnosis overlaps with Belowea Won, 1983, which is now regarded as a junior synonym to Entactinosphaera Foreman, 1963.

\section{Thecentactinia Nazarov, 1975}

Thecentactinia Nazarov, 1975b: 71.

TYPE SPECIES. - Entactinosphaera riedeli Foreman, 1963 (Foreman 1963: 275, pl. 5, fig. 4a-c, pl. 6, fig. 9).

Age and location of type material. - Upper Devonian, Kazakhstan.

TAXON CODE. -126 .

STATUS. - Junior synonym of Entactinosphaera Foreman, 1963 (by Won 1997a).

DiAGNOSIS. - “Три сферические решетчатые оболочки, связанные с внутренней шестилучевой спикулой посреАством тонких мучей, образующихся от ее концов”. (Nazarov 1975b: 71).

DiAgNOSIS (English translation of Nazarov [1975b] by E. Roden in the rad database microfiche collection of Bill Riedel). - "Three spherical latticed shells, connected to the inner six-rayed spine by means of thin rays, which are formed at its ends".

DiAgnosis [English translation by J. P. Caulet - RadWorld database]. - Internal structure as a six-rayed spicule with thin rays 
emanating from a median bar (6-8 $\mu \mathrm{m}$ long). Three envelopes. Internal envelope, mostly porous, of a diameter 35-55 $\mu \mathrm{m}$; intermediate envelope, lattice, rarely porous, of a diameter 85-105 $\mu \mathrm{m}$; external envelope, with small pore, rarely lattice. Six external main spines, rarely less, from one to five.

\section{REMARKS}

Won (1997a) discusses this genus and comments that it is unclear whether it and Entactinosphaera are synonyms (she spells its name as Thecoentactinia following the spelling error of Nazarov \& Ormiston [1990], who follow the first spelling of the name of this genus when introduced as a nomen nudum in Nazarov [1975a: 39]). Shortly after, Nazarov fully described the genus in his opus on radiolarians from Kazahkstan (Nazarov 1975b: 71).

Trilonche Hinde, 1899

sensu Aitchison \& Stratford (1997)

Trilonche Hinde, 1899a:47. — Aitchison \& Stratford 1997: 374.

Bientactinosphaera Afanasieva, 2000a: 371.

Bisphaera Won, 1997a: 344.

Druppalonche Hinde, 1899b: 217 (n. syn.)

Duosphaera Won, 1998: 235.

Ornatoentactinia Afanasieva, 2000a: 373 (n. syn.)

Staurodruppa Hinde, 1899a: 51.

TyPe SPECIES. - Trilonche vetusta Hinde, 1899 (Hinde 1899a: 48, pl. 8, fig. 18)

Age And location of TyPe MATERIAL. - Middle Devonian (Givetian), Yarrimie Formation, New South Wales, Australia.

TAXON CODE. - 127.

STATUS. — Valid.

DiAGNOSIS. - "The test consists of two concentric latticed spheres, with three radial spines at equal or unequal distances apart. Secondary surface spines are also sometimes present." (Hinde 1899a: 47).

EMENDED DIAGNOSIS. - " "Two or more, well developed, spherical or sub-spherical shells, and an internal, six-rayed double spicule. When secondary spines are present, the six spines developed from the rays of the internal spicule are generally considerably more robust and are easily recognizable as main spines. Up to six spines may be present." (Aitchison \& Stratford 1997: 374).

\section{Uberinterna Sashida \& Tonishi, 1988}

Uberinterna Sashida \& Tonishi, 1988: 531.

TYPE SPECIES. — Uberinterna virgispinosum Sashida \& Tonishi, 1988 (Sashida \& Tonishi 1988: 531, fig. 8.7).

Age and location of type material. - Upper Permian, Itsukaichi, central Japan.

TAXON CODE. -128 .

STATUS. — Valid.
DiAGNOSIS. - "Astroentactiniinae with thick spongy outer shell and porous inner shell. Inner shell comprises 4 to 5 , rarely more, thin concentric spheres. Internal spheres connected with each other by numerous thin rod-like beams. Internal spheres also being crossed by radial cross-beams joining with base of major spines." (Sashida \& Tonishi 1988: 531).

\section{Wonella Afanasieva, 2000}

Wonella Afanasieva, 2000c: 34.

TYPE SPECIES. - Retentactinia impedita Won, 1997 (Won 1997b: 385, pl. 6, fig. 14, 15, 18-20).

Age and location of type Material. - Frasnian, (Upper Devonian), Gogo Formation, Canning Basin, western Australia.

TAXON CODE. - 129 .

STATUS. - Homonym - replacement name Munzuwonella Afanasieva, 2009.

DiAGNOSIS. - "Раковина сферическая с одной решетчатой оболочкой. Внутренний каркас представлен спикулой, шесть мучей которой расходятся от срединной балки. Продолжением мучей спикулы явмяются основные трехгранные игмы” (Afanasieva 2000с: 34).

DiagNOSIS (English translation by Paulian Dumitrica). - Test consisting of a spherical lattice shell. Internal skeleton represented by a spicule, with six rays that diverge from the median bar. Rays are prolonged into three-bladed spines.

Wuyia Feng in Feng, Gu, He \& Jin, 2007

Wuyia Feng in Feng, Gu, He \& Jin, 2007: 31.

TyPe SPECIES. - Wuyia dongpanica Feng in Feng, Gu, He \& Jin, 2007 (Feng in Feng et al. 2007: 33, pl. 5, fig. 9-12 19).

Age AND location of TyPe MATERIAL. - Upper Changhsingian (uppermost Permian), Dalong Formation, Southern Guangxi, South China.

TAXON CODE. -130 .

STATUS. - Valid.

DiAGNOSIS. - "Spherical test composed of three concentric shells and a small microsphere." (Feng et al. 2007: 31).

\section{Family HAPLENTACTINIIDAE \\ Nazarov in Nazarov \& Popov, 1980 \\ (nomen translatum Nazarov \& Ormison 1984) \\ Arcoclathrata Afanasieva \& Amon, 2016}

Arcoclathrata Afanasieva \& Amon, 2016: 217.

TyPe SPECIES. - Arcoclathrata alekseevi Afanasieva \& Amon, 2016 (Afanasieva \& Amon 2016: 219, pl. 2, fig. 6-15).

Age and location of type material. - Lower Permian, CisUrals, Russia.

TAXON CODE. - 131 .

STATUS. — Valid. 
Diagnosis. - "Skeleton spherical, with two shells: latticed external and porous internal. Latticed shell formed of interlacing round or laminate rods (resembling woven basket), space between which usually free, but sometimes closed by additional poorly preserved thin skeletal tissue. Internal skeleton represented by potential six-ray spicule, rays of which continued by massive three-bladed main spines with Y-shaped base section. Number of main spines unstable, ranging from 1 to 6 . Internal rod-shaped spines frequently diverging from nodes of interpore bars of internal sphere and continued by external by-spines." (Afanasieva \& Amon 2016: 211)

\section{Arrhiniella Kozur \& Mostler, 1981}

Arrhiniella Kozur \& Mostler, 1981: 4.

TYPE SPECIES. - Haplentactinia arrhinia Foreman, 1963 (Foreman 1963: 270, pl. 1, fig. 1, pl. 3, fig. 1).

Age AND location of tyPE MATERIAL. - Frasnian, (Upper Devonian), Ohio Shale, Ohio USA.

TAXON CODE. - 132 .

STATUS. - Junior synonym of Haplentactinia Foreman, 1963 (herein)

DiAGNOSIS. - "Spicularsystem punktzentriert. Die 6 Spicularstacheln sind in drei aufeinander senkrecht stehenden Achsen angeordnet und besitzen ein oder zwei Niveaus mit Apophysen." (Kozur \& Mostler 1981: 4).

DiAgnosis (English translation by J. P. Caulet - RadWorld database). - "Point-centered spicular system. The six spicular spines distributed in three axes perpendicular to each other and bearing one or two layers of apophyses."

\section{REMARKS}

The two species originally illustrated by Foreman (Haplentactinia arrhinia and $H$. rhinophyusa) are too similar structurally to be included in two different genera.

\section{Bissylentactinia Nazarov, 1975}

\section{Bissylentactinia Nazarov, 1975b: 93.}

TYPe sPeCIES. - Bissylentactinia rudicula Nazarov, 1975 (Nazarov 1975b: 94, pl. 13, fig. 1, pl.14, fig. 1).

Age And location of type material. - Lower to Middle Ordovician of Kazakhstan.

TAXON CODE. - 133.

STATUS. — Valid.

DIAGNOSIS. - “Шесть-двенадцать игл, расходящихся от срединной точки, с апофизами на одном или Авух уровнях каждой иглы”. (Nazarov 1975b: 93).

DiagnOSIS (English translation of Nazarov [1975b] by E. Roden in the rad database microfiche collection of Bill Riedel). - Six to twelve spines, radiating from a medial point, with apophyses on one or two levels on each spine.
Haplentactinia Foreman, 1963

Haplentactinia Foreman, 1963: 270.

Arrhiniella Kozur \& Mostler, 1981: 4 (n. syn.)

TYPE SPECIES. - Haplentactinia rhinophyusa Foreman, 1963 (Foreman 1963: 270, pl. 1, fig. 2, pl. 3, fig. 7)

AgE AND LOCATION OF TYPE MATERIAL. - Upper Devonian, Huron member, Ohio Shale, USA.

TAXON CODE. - 134 .

STATUS. — Valid.

DiAgNOSIS. - "Six-rayed double spicule with branches arising at two levels along each ray and sometimes forming an irregular lattice-shell." (Foreman 1963: 270).

\section{Syntagentactinia Nazarov in Nazarov \& Popov, 1980}

Syntagentactinia Nazarov in Nazarov \& Popov, 1980: 56.

TYPE SPECIES. - Syntagentactinia biocculosa Nazarov in Nazarov \& Popov, 1980: 56, pl. 12, fig. 1-3.

AgE AND LOCATION OF TYPE MATERIAL. - upper Dapingian - lower Sandbian (Middle Ordovician), Kazakhstan.

TAXON CODE. -135 .

STATUS. — Valid.

DiagNOSIS. - Haplentactiniinae, “имеющие внутренний каркас, преАставленный стержневидными иглами, явмяющиеся непосреАственным продолжением шести кучей внутренней спикулы. Н С! иглах имеются Аве группировки апофизов, соединение которых образует Аве хорошо развитые решетчатые оболочки" (Nazarov in Nazarov \& Popov 1980: 56).

Diagnosis (English translation by J. P. Caulet - RadWorld database). - "Haplentactiniinae with an internal structure, represented by rod-like spines, directly originating from the six internal rays. Two groups of apophyses from these rods unit to provide two welldifferentiated latticed shells".

Family Palaeolithocycliddae Kozur \& Mostler, 1989

Eostylodictya Ormiston \& Lane, 1976

Eostylodictya Ormiston \& Lane, 1976: 170.

TYPE SPECIES. - Eostylodictya eccentrica Ormiston \& Lane, 1976 (Ormiston \& Lane 1976: 171, pl. 4, fig. 1-6).

Age AND LOCATION OF TYPE MATERIAL. - Upper Carboniferous, Sycamore Limestone, USA.

TAXON CODE. -136 .

STATUS. - Junior synonym of Palaeolithocyclia Kozur \& Mostler, 1972 (by Dumitrica in De Wever et al. 2001: 182).

DiAGNOSIS. — "Phacoid cortical shell, internally with single medullary shell bordered by multiple concentric rings, periphery of cortical shell with short spines in equatorial plane. Cortical shell either with or without pores." (Ormiston \& Lane 1976: 170). 


\section{REMARKS}

Although the description of radiolarian species or genera of radiolarians based on thin sections is not recommended, Paleolithocyclia, based on Lithocyclia micrococcus described from thin sections by Rüst (1892: 22, fig. 4), is one of the rare cases when a section approximates the genus rather well and can be shown to have the same features as Eostylodictya.

\section{Gedauia Won, 1983}

\section{Gedauia Won, 1983: 153.}

TYPe SPECIES. — Gedauia bibrachialis Won, 1983 (Won 1983: 153, pl. 3, fig. 1-8, pl. 14, fig. 6, text-fig. 5n-q).

AgE AND LOCATION OF TYPE MATERIAL. - Lower Carboniferous, Rheinischen Schiefergebirge, Germany.

TAXON CODE. - 137 .

STATUS. - Junior synonym of Paramphibrachium Kozur \& Mostler, 1978 (by De Wever et al. 2001: 182).

DiagNosis. — "Das Skelett besteht aus einer oder mehreren sphäroidalen zentralen Schalen, die von einigen konzentrischen, äquatorialen, reifenförmigen, peripheren Schalen umgeben sind. Alle Schalen bestehen aus einem Gitterwerk. Dem Rand der Reifenschalen entspringen in variabler Zahl markante Arme. Jeder Arm besteht aus zahlreichen, zusätzlichen, zueinander kongruent angelegten Reifenschalenteilen. Die Oberflächenstruktur der Arme ist im Gegensatz zum Mittelteil des Skeletts nicht schichtig, sondern eher mit der Struktur einer Siebplatte vergleichbar." (Won 1983: 153).

DiAgnosis (English translation by J. P. Caulet RadWorld database - modified by Jörg Maletz). - "Test consists of one or several spherical central shells, surrounded by a concentric, equatorial, annular, peripheral shell. All shells latticed. A variable number of arms originate from the border of the annular shell. Each arm constituted by numerous additional and anastomosed parts of the annular shell. Contrary to the median part of the test, the surface structure of the arms is not multi-layered, but it can be compared to the structure of a porous plate."

\section{REMARKS}

Although the central part of the type species of Paramphibrachium (Amphymenium alienum Rüst, 1892) does not show a spherical shell inside, it can be inferred. Rüst's drawing (Rüst 1892: pl. 24, fig. 2) can be compared with the image in transmitted light of Gedauia bibrachialis in Won (1983: pl. 14 , figs $6 \mathrm{a}, 6 \mathrm{~b})$, which is considered a synonym.

\section{Palaeoastrocyclia Kozur \& Mostler, 1972 sensu Kozur \& Mostler (1989)}

Palaeoastrocyclia Kozur \& Mostler, 1972: 16; 1989: 197.

TYPE SPECIES. - Lithocyclia ulrichi Rüst, 1892 (Rüst 1892: 166, pl. 22, fig. 3).

Age AND LOCATION OF TYPE MATERIAL. - Lower Carboniferous, Harz Mountains, Germany.

TAXON CODE. -138.
STATUS. - Junior synonym of Palaeolithocyclia Kozur \& Mostler, 1972 (by Dumitrica in De Wever et al. 2001: 182).

Original Diagnosis. — "Die discoidale bis kugelige, an den Polen etwas abgeflachte Gitterschale wird von einem äquatorialen Gürtel umgeben, der aus zwei bis vier konzentrischen Ringen besteht, die durch Radialbalken verbunden sind. Gitterscheibe zwei- oder einschichtig. Poröse Deckplatten fehlen. Bandzone bestachelt.” (Kozur \& Mostler 1972: 16).

EMENDED DIAGNOSIS. - "Skelett phacoidal, discoidal oder subsphärisch mit abgeflachten Polen. Einschließlich der großen sphärischen Markschale existieren 1-8 kugelige geschlossene Schalen, die nur einen geringen Abstand voneinander aufweisen sowie 2-10 periphere Reifenschalen (ebenfalls mit geringem gegenseitigen Abstand), welche die äußere der geschlossenen Schale wie ein äquatorialer Reifen umhüllen, dessen Höhe zum Rand hin abnimmt. Alle Schalen sind gegittert und sie sind durch zahlreiche radiale Stacheln verbunden, die von der Markschale ausstrahlen und am Rand der äußersten Schale enden oder als äquatoriale Radialstacheln überstehen. Die äußere Oberfläche erscheint im Bereich der Reifenschalen meist spongiös, weil hier die offenen, sehr niedrigen Schalen und die verbindenden Radialstacheln zu sehen sind und nicht die gegitterte Oberfläche der Schalen, wie in den beiden Polregionen (offene Oberfläche der äußeren Zentralschale, nicht von den unvollständigen Reifenschalen bedeckt). In Äquatorebene sind etwa 20 kurze, kräftige Radialstacheln vorhanden. Hauptstacheln oder Arme treten nicht auf. Auf der Oberfläche liegt exzentrisch ein aufgewölbtes Pylom-Sieb." (Kozur \& Mostler 1989: 197).

EMENDED DIAGNOSIS (English translation by J. P. Caulet - RadWorld database). - "Shell phacoidal, discoidal, or subspherical, with flattened poles. 1-8 spherical closed shells around a large medullary shell formed at close distances. Additionally, 2-10 circular shells (also with small intervals between these) enveloping the external closed shell like an equatorial ring whose height decreases towards the rim. All shells latticed and linked by numerous radial spines extending from the medullary shell to the border of the external-most shell, or protruding outside of it as equatorial radial spines. External surface mostly spongy in the area of the equatorial ring, where the flat shells and radial beams are visible, and latticed in both polar areas where the surface of the central shell is not entirely covered by the incomplete circular shells. Nearly 20 short and strong radial spines in the equatorial plane. No main spines, or arms. An eccentrically curved pylome on the surface."

\section{REMARKS}

Kozur \& Mostler (1989) emended their 1972 diagnosis of this genus and synonymized it with Eostylodycta Ormiston \& Lane, 1976. Palaeoastrocyclia can, also be synonymized with Palaeolithocyclia because both genera have the same structure: a rather large central sphere surrounded in the equatorial plane by a test disposed in concentric layers with radial structure.

\section{Palaeolithocyclia Kozur \& Mostler, 1972 sensu Kozur \& Mostler (1989)}

Palaeolithocyclia Kozur \& Mostler, 1972: 17; 1989: 196.

Palaeoastrocyclia Kozur \& Mostler, 1972: 16; 1989: 197.

Eostylodictya Ormiston \& Lane, 1976: 170.

Sphaerodiscus Won, 1983: 163. 
TyPE SPECIES. - Lithocyclia macrococcus Rüst, 1892 (Rüst 1892: 166, pl. 22, fig. 4).

Age AND LOCATION Of TYPE MATERIAL. - Upper Devonian, Mangankiesel, Schaebenholz, Harz Mountains, Germany.

TAXON CODE. - 139 .

STATUS. - Valid.

Original DiAgnosis. - "Die spongiöse bis fein gegitterte Schale wird von einer äquatorialen Scheibe umgeben, die vier bis fünf regelmäßig oder unregelmäßig konzentrische Porenringe enthält. Außenrand der Scheiben glatt oder höchstens fein gezähnelt. Keine porösen Deckplatten ausgebildet” (Kozur \& Mostler 1972: 17).

EMENDED DIAGNOSIS. - "Eine große kuglige feinporige, schwammige bis fast dichte Schale wird von einer äquatorialen Scheibe umgeben, die aus sehr niedrigen Schalenringen aufgebaut ist. Diese sind durch dicht nebeneinander liegende nadelförmige Radialstacheln miteinander verbunden, die von der Markschale ausstrahlen und bis an den Außenrand der Scheibe reichen oder hier geringfügig überstehen. In polarer Anordnung können längere Stacheln überstehen, die in kurze armähnliche Fortsätze eingeschlossen sind." (Kozur \& Mostler 1989: 196).

EMENDED DIAGNOSIS (English translation by J.P Caulet RadWorld database). - Large spherical shell, finely porous, spongy to nearly compacted, and surrounded by an equatorial disc built by very narrow shell rings. Rings linked by co-lateral spindle-shaped radial spines originating from the medullary shell and extending out to the external border of the disc, or slightly protruding above it. Longer spines may extend in polar areas and be joined as short arm-like appendages.

\section{Paramphibrachium Kozur \& Mostler, 1978 sensu Kozur \& Mostler (1989)}

Paramphibrachium Kozur \& Mostler, 1978: 143; 1989: 197.

Gedauia Won, 1983: 153.

TYPE SPECIES. - Amphymenium alienum Rüst, 1892 (Rüst 1892: 170, pl. 24, fig. 2).

Age AND location of type MATERial. - Upper Devonian Mangankiesel, Schaebenholz, Harz Mountains, Germany.

TAXON CODE. -140 .

STATUS. - Valid

ORIGINAL DIAGNOSIS. — "Zentrale Scheibe rundlich, z.T. asymmetrisch, sehr groß. Die zwei Arme sind verhältnismäßig kurz. Die Poren sind unregelmäßig verteilt oder andeutungsweise axial, z.T. auch andeutungsweise knozentrisch angeordnet." (Kozur \& Mostler 1978: 143).

EMENDED DIAGNOSIS. — "Einschließlich der Markschale sind zentral 1-3 kuglige Schalen in geringem gegenseitigen Abstand vorhanden. Sie werden von 4-6 dicht aufeinander folgenden Reifenschalen umgeben, die nur im äquatorialen Bereich entwickelt sind. Am Rand der Reifenschalen entspringen 2 gegenüber liegende, selten auch 3 Arme, die aus zahlreichen weiteren, dicht aufeinander folgenden perforierten Reifenschalensegmenten bestehen. Alle Schalen, einschließlich der Reifenschalensegmente in den Armen sind durch dicht stehende radiale, von der Markschale ausgehende nadelförmige Stacheln miteinander verbunden. In den Armen kommen die radialen Elemente, die am Außenrand aussetzen, stärker zur Geltung als die konzentrischen. Alle Schalen und Schalensegmente sind perforiert (gegittert) bis spongiös (? erhaltungsbedingt). Durch den geschilderten Innenbau des Gehäuses ist der Mittelteil des Skeletts bikonvex, während die Arme zylindrisch bis abgeplattet zylindrisch mit rundlichem bis ovalem Querschnitt sind."(Kozur \& Mostler 1989: 197).

EMENDED DIAGNOSIS (English translation by J. P. Caulet - RadWorld database - modified by Jörg Maletz). - Three to four central spherical shells (including the medullary shell) distributed at close intervals. Shells surrounded by 4-6 closely distributed annular shells only developed in the equatorial area. On the sides of these rings, 2 opposite, rarely 3 arms constituted by numerous secondary segments of perforate annular shells. All shells, including the arm segments, are linked by closely distributed radial spines, spindleshaped, originating from the medullary shell and joined altogether. The radial structures that are missing on the external sides, become more important on the arms than the concentric ones. All shells and shell segments porous (latticed?) to spongy (state of preservation?). Middle part of the shell convex, while the arms are cylindrical to flattened cylindrical, with circular to oval cross-sections.

\section{REMARKS}

The reason for this synonymy is discussed under Gedauia Won, 1983.

\section{Sphaerodiscus Won, 1983}

Sphaerodiscus Won, 1983: 163.

TYPe SPECIES. - Sphaerodiscus rota Won, 1983 (Won 1983: 163, pl. 3, fig. 9, 10, 14, pl. 14, fig. 7, text-fig. 5r, s).

AgE AND LOCATION OF TYPE MATERIAL. - Lower Carboniferous, Rheinischen Schiefergebirge, Germany.

TAXON CODE. -141 .

STATUS. - Junior synonym of Palaeolithocyclia Kozur \& Mostler, 1972 (by Dumitrica in De Wever et al. 2001).

DiAGNOSIS. — "Das Skelett besteht aus einer zentralen, sphäroidalen Schale und einem scheiben- bis ringförmigen peripheren Teil. Die Zentralschale ist aus sehr dichtem Gitterwerk, die Peripheriescheibe hingegen aus einem dreidimensionalen Quader-Gerüst aufgebaut. Zentralschale und Peripheriescheibe sind in der Äquatorebene mittels Dornen verbunden. Radialstacheln können vorhanden sein.” (Won 1983: 163).

Diagnosis (English translation by J. P. Caulet - RadWorld database). - Test with a central, spherical shell, and a discoidal to annular periphery. Dense central lattice shell, peripheral disc, of a three-dimensional cube skeleton. Central shell connected to the peripheral disc by spines in the equatorial plane. Radial spines may be present.

\section{REMARKS}

The shape and structure of this genus are similar to those of Palaeolithocyclia Kozur \& Mostler, 1972.

Family PalaeosCEnididdae Riedel, 1967

Deflantrica Wakamatsu, Sugiyama \& Furutani, 1990

Deflantrica Wakamatsu, Sugiyama \& Furutani, 1990: 167. 
TYPe SPECIES. - Parentactinia vetustum Furutani, 1983 (Furutani 1983: 108, pl. 21, fig. 4-5, pl. 22, fig. 4).

AgE AND LOCATION OF TYPE MATERIAL. - Lower or Middle Devonian, G4 Formation, Mt. Yokokura, Kochi Prefecture, Shikoku, Japan.

TAXON CODE. -142 .

STATUS. — Valid.

DiagnOSIS. - "Palaeoscenidiidae with single, incomplete spherical lattice shell. The shell disposed under the basal spines, penetrated by numerous pores various in shape and size, incomplete in its apical part, never contains parts of the basal spines in it. Palaeoscenidiumtype spicule composed of four apical and four basal spines, a short median bar, and tent-like lamellar shell connecting the proximal parts of basal spines and median bar. Spinules sometimes present on the spines." (Wakamatsu et al. 1990: 167).

\section{Fukujius Furutani, 1990}

Fukujius Furutani, 1990: 46.

TYPe SPECIES. - Fukujius yamakoshii Furutani, 1990 (Furutani 1990: 47, pl. 9, fig. 4-5).

Age and location of type material. — Middle Paleozoic, Honshu, Japan.

TAXON CODE. -143.

STATUS. - Nomen dubium.

DiAGNOSIS. - "From each end of a short median bar six spines arise. The contents of the spines are an apical spine, 3 lateral spines, and 2 basal spines. The lateral spines are nearly horizontal or weakly bent down." (Furutani 1990: 46).

\section{REMARKS}

From the single figured specimen of the single species assigned to this genus it is not possible to clearly observe the characteristics of the genus.

\section{Goodbodium Furutani, 1990}

\section{Goodbodium Furutani, 1990: 43.}

Type sPeCIEs. - Palaeoscenidium flammatum Goodbody, 1986 (Goodbody 1986: 152, pl. 1, fig. 1-4).

Age AND LOCATION OF TYPE MATERIAL. - Wenlockian, Silurian, Cape Phillips Formation, Arctic Canada.

TAXON CODE. -144 .

STATUS. - Junior synonym of Palaeoscenidium Deflandre, 1953.

DiagnOSIS. - "Basic spicule is composed of a short median bar and 4 short apical spines and 4 long basal spines. One of the apical spines often well developed in some species. Thin lamellae more or less develop between neighboured basal spines at near the proximal end of the basals. Spinules arise from the proximal part of the basals and parallelly elongate each other on the surface of the quadrangular pyramid edged by the 4 basal spines. Spicules amalgamate to make a lamellae or net in some species." (Furutani 1990: 43).

\section{REMARKS}

Amon et al. (1995: 7) assigned the type species to Palaeoscenidium, noting that the development of the spinules that form the net varies with ontogeny and preservation. MacDonald (2004: 260) argues that the validity of this genus is not based on the development of the spinules, but on the stability and position of the ray number (8). He offers an emendation to the diagnosis, but it is not consistent with his discussion and, as a consequence, it is not adopted herein. Despite the stability of the ray position, the description overlaps with that of Palaeoscenidium, for which reason the genus is treated as a junior synonym.

\section{Holdsworthum Furutani, 1990}

Holdsworthum Furutani, 1990: 44.

TYPE SPECIES. - Holdsworthum japonicum Furutani, 1990 (Furutani 1990: 45, pl. 8, fig. 8-10, pl. 9, fig. 1).

AgE AND LOCATION OF TYPE MATERIAL. - Upper Silurian or Lower Devonian, Horizons O-2, -4, -7, Osobudani Valley, Fukuji area, Gifu Prefecture, Japan.

TAXON CODE. -145 .

STATUS. - Valid.

DiagnOSIS. - "Basic spicule is composed of a median bar, 4 or 3 basal spines, and 2 or more apical spines. Basal spines make a conical net by the repetitions of bifurcation and the amalgamation of the branches. In the proximal part of the net poreless or porous lamellae develop. A laterally elongated spine may arise from a basal spine. Other spinules may arise from basal spines to the outside of the cone. One of the basal spines is sometimes dwarfish." (Furutani 1990: 44).

\section{Insolitignum MacDonald, 1999}

Insolitignum MacDonald, 1999: 2053.

Type SPeCIES. — Palaeoephippium dissimile Goodbody, 1986 (Goodbody 1986: 140, pl. 3, fig. 10-12).

AgE AND LOCATION OF TYPE MATERIAL. - Upper Llandovery to lower Wenlock (Silurian), Cape Phillips Formation, Canadian Arctic.

TAXON CODE. -146 .

STATUS. - Valid.

DiAGNOSIs. - "Six rays, three from each end of median bar; two rays in apical position, three in basal position, one ray (principal ray) in variable position; principal ray may bear microspinules; other rays variably ornamented." (MacDonald 1999: 2053).

\section{Pactarentinia Furutani, 1983}

Pactarentinia Furutani, 1983: 109.

TYPE SPECIES. - Pactarentinia holdsworthi Furutani, 1983 (Furutani 1983: 109, pl. 22, fig. 5-6, pl. 23, fig. 1-6).

Age AND LOCATION OF TYPE MATERIAL. - Lower or Middle Devonian, G4 Formation, Mt. Yokokura, Kochi Prefecture, Shikoku, Japan. 
TAXON CODE. -147.

STATUS. — Valid.

DiAGNOSIS. - "Palaeoscenidiinae with single spherical lattice shell and rod- or needle-like spines. A part of each basal spine covered by the shell. The median bar is situated above the shell." (Furutani 1983: 109).

\section{Palaeodecaradium Goodbody, 1986}

Palaeodecaradium Goodbody, 1986: 136.

Palaeotripus Goodbody, 1986: 152.

TYPE SPECIES. - Palaeodecaradium umbelliforme Goodbody, 1986 (Goodbody 1986: 136, pl. 3, fig. 5-9).

AgE AND LOCATION OF TYPE MATERIAL. - Upper Llandovery to lower Wenlock (Silurian), Cape Phillips Formation, Canadian Arctic.

STATUS. - Valid.

TAXON CODE. -148 .

DiAGNOSIS. - "Spicular radiolarian skeleton consisting of two apical rays, four basal rays and four rays in an attitude between apical and basal." (Goodbody 1986: 136).

\section{Palaeoephippium Goodbody, 1986 sensu MacDonald (2004)}

Palaeoephippium Goodbody, 1986: 138. — MacDonald 2004: 270. Palaeotrifidus Renz, 1990: 374 (n. syn.)

Type sPeCIES. — Palaeoephippium bifurcum Goodbody, 1986 (Goodbody 1986: 139, pl. 4, fig. 1-4).

Age and location of type Material. - Middle Wenlock to lower Ludlow (Silurian), Cape Phillips Formation, Canadian Arctic.

TAXON CODE. - 149 .

STATUS. — Valid.

DiAGNOSIS. - "Six-rayed radiolarian skeleton. One apical ray, two basal rays arising from each end of bar center. Spinulation or branching may occur on rays; spinules from adjacent rays not fusing to form cohesive shell structures" (Goodbody 1986: 138).

\section{REMARKS}

MacDonald (2004) proposes an emendation to this genus after observing that the position of the rays may vary between basal, apical, and intermediate positions. His Emended diagnosis, "At least six rays; basal rays branch once or repeatedly; apical rays branched or unbranched" (MacDonald 2004: 270) maintains the number of rays, but notes the varied position of one of the rays. The number of apical rays is not specified but is either 2 or 3 , depending on the variable ray position, so that the total number of rays adds up to 6. MacDonald (2004) does not specify branching of basal rays, but this is an important distinction between this genus and Palaeoscenidium Deflandre 1953 , which has straight basal rays.
Palaeopyramidium Goodbody, 1986

Palaeopyramidium Goodbody, 1986: 147.

TyPe SPECIES. - Palaeopyramidium spinosum Goodbody, 1986 (Goodbody 1986: 148, pl. 2, fig. 5-8).

AgE AND LOCATION OF TYPE MATERIAL. - Uppermost Llandovery to middle Wenlock (Silurian), Cape Phillips Formation, Canadian Arctic.

TAXON CODE. -150 .

STATUS. - Valid.

DiAgnOSIS. - "Five-rayed radiolarian skeleton. One apical ray and four basal rays arising from a point center. Basal rays regularly arranged to form a pyramid. Apical ray erect." (Goodbody 1986: 147)

Palaeoscenidium Deflandre, 1953 sensu Furutani, 1983

Palaeoscenidium Deflandre, 1953: 408. — Furutani 1983: 107

Goodbodium Furutani, 1990: 43.

Type species. - Palaeoscenidium cladophorum Deflandre, 1953 (Deflandre 1953: 408, fig. 308).

Age AND LOCATION OF TYPE MATERIAL. - Visean (Carboniferous), Cabrières, Montagne Noire, France.

TAXON CODE. - 151 .

STATUS. - Valid

Diagnosis. - "En forme de tente à 4 arêtes prolongées par de solides cornes épineuses, tient des Plectoidae par son squelette important, mais l'existence d'une coque bien individualisée en ferait un Cyrtoidea (Monocyrtida) si cette coque était treillissée ou perforée mais non mince, membraneuse, comme elle l'est en réalité." (Deflandre 1953: 408).

Diagnosis (English translation by Taniel Danelian). - "In the form of a tent with four ridges extending to robust thorny horns, has affinities with the Plectoidae by its extensive skeleton, but the existence of a distinct shell suggests a Cyrtoidea (Monocyrtida) if this shell was latticed or perforated, but not thin, membranous, as it really is."

\section{REMARKS}

There have been several proposed emendations to Deflandre's brief description of this genus (Furutani 1983; Goodbody 1986; MacDonald 2004). Furutani (1983: 106, 107), in his revisions to the family Palaeoscenidiidae Riedel, 1967, notes that most of the palaeoscenids from his material have four basal spines, and in his proposed diagnosis of Palaeoscenidium, the shell is tent-like, and the basal spines are straight and do not form rings. The number of apical spines is 1-4, as with the Palaeoscenidiinae Riedel, 1967. In following Furutani's emendations, this genus would encompass Goodbodium Furutani, 1990 (see remarks under Goodbodium), but excludes many of the other Paleozoic genera that differ in the number of basal rays and in possessing bifurcations of these rays. 


\section{Palaeothalomnus Deflandre, 1973}

Palaeothalomnus Deflandre, 1973b: 497; 1973a: 290 (nomen nudum).

TyPe SPECIES. - Palaeothalomnus antiquus Deflandre, 1973 (Deflandre 1973a: 290, pl. 1, fig. 1-2).

AgE AND LOCATION OF TYPE MATERIAL. - Visean (Lower Carboniferous), Cabrières, Hérault, Montagne Noire, France.

TAXON CODE. -152 .

STATUS. - Valid.

DiAGNOSIS. - "Spicule siliceux à n branches cylindriques issues d'un point central; chaque branche ou actine porte un verticille irrégulier d'épines assez longues et variées, ou parfois un bouquet de cornes." (Deflandre 1973b: 497).

DiAgNosis (English translation by J. P. Caulet - RadWorld database). - "Siliceous spicule with cylindrical branches arising from a central point; each branch bears a vertical of irregular spines, long and various, or sometimes a bunch of spinules."

\section{REMARKS}

Personal observations made by the coauthor (Dumitrica) of Deflandre's material indicate that this genus should be placed in the family Paleoscenidiidae. The spicule has a very short median bar. From one end of MB radiate 4 spines of which 2 are long and equal, one is shorter and obliquely upward directed, and one short also, simple, obliquely downward. From the other end radiate two long spines equal with the long spines from the opposite end, and, it seems, a short spine below. All spines except the two short spines downwardly directed bear a bunch of spinules.

\section{Palaeotrifidus Renz, 1990}

Palaeotrifidus Renz, 1990: 374 (n. syn.)

TyPe SPECIES. - Palaeotrifidus ballator Renz, 1990 (Renz 1990: 374, pl. 3, fig. 4, 6, 8-10).

Age AND LOCATION OF TYPE MATERIAL. - Katian, Upper Ordovician, Nevada.

TAXON CODE. - 153 .

STATUS. - Junior synonym of Palaeophippium Goodbody, 1986 (herein).

DiAgNOSIS. - " "Two strong equal apical spines radiate at less than right angles to each other from a very short central bar or point. Three similarly strong but longer basal spines radiate at equal angles below the bar, sometimes bifurcating distally. Secondary spines present on occasion show different forms of multiple branching, sometimes meeting and forming an encircling girdle." (Renz 1990: 374).

\section{REMARKS}

This genus fits with the description of Palaeophippium Goodbody, 1986, as it overlaps in both the position and number of rays, as well as the branching of the basal rays. Noble \& Webby (2009: 555) indicated that the type species of this genus showed large variation, including instability of the position of the rays between apical, basal, and intermediate positions, and synonymized the type species, Palaeotrifidus ballator, with Palaeoephippium octaramosum (each of which had previously been assigned different genera based on the position of the rays).

\section{Palaeotripus Goodbody, 1986}

Palaeotripus Goodbody, 1986: 152.

TyPe SPECIES. - Palaeotripus nudus Goodbody, 1986 (Goodbody 1986: 154 , pl. 1, fig. 8).

Age And location of TyPe MATERial. - Wenlockian, Silurian, Cape Phillips Formation, Arctic Canada.

TAXON CODE. -154 .

STATUS. - Junior synonym of Palaeodecaradium Goodbody, 1986 (by MacDonald 2004).

DIAGNOSIS. - "Six rays arising from point to bar center, these clearly distinguishable into three apical and three basal rays. Apical rays usually noticeably shorter than basal rays." (Goodbody 1986: 152).

\section{REMARKS}

MacDonald (2004: 268) synonymizes the type species, Palaeotripus nudus Goodbody, 1986, with Palaeodecaradium apertum Goodbody, 1986, noting that the designation of a fixed number of apical and basal rays is arbitrary, and forces some intraspecific variation to be regarded as a genus level distinction. Other species of Palaeotripus have also been synonymized with otherwise identical species artificially split into separate genera because of differences in ray position and number (i.e., P. monospinosus Goodbody, 1986 by MacDonald [2004: 271]; P. sextabranchiatus Renz, 1990 by Noble \& Webby [2009: 555]).

\section{Palaeoumbraculum Amon, Braun \& Ivanov, 1995}

Palaeoumbraculum Amon, Braun \& Ivanov, 1995: 8.

TyPe SPECIES. - Palaeoumbraculum expandum Amon, Braun \& Ivanov, 1995 (Amon et al. 1995: 8, pl. 2, fig. 1, text-fig. 12a).

AgE AND LOCATION OF TYPE MATERIAL. - Upper Silurian, Southern Urals.

TAXON CODE. -155 .

STATUS. — Junior synonym of Praesaturnalis Li, 1994 (Dumitrica in De Wever et al. 2001).

DiAgNOSIS. - "A new genus geometrically similar to Paleodecaradium Goodbody, 1986, but differing from this genus in that the basal rods are arranged in one plane like the ribs of an umbrella." (Amon et al. 1995: 8).

\section{REMARKS}

In De Wever et al. (2001) the genus was considered a junior synonym of Praesaturnalis Li, 1994 and included in the family Secuicollactidae. 


\section{Praesaturnalis Li, 1994}

Praesaturnalis Li, 1994: 269.

Palaeoumbraculum Amon, Braun \& Ivanov, 1995: 8.

TYPE SPECIES. - Praesaturnalis septemistellatus Li, 1994 (Li 1994: 269, pl. I, fig. 15, pl. II, fig. 11).

Age and location of TyPe Material. - Middle Silurian, Keerhada, Xinjiang western China.

TAXON CODE. - 156 .

STATUS. — Valid.

\section{REMARKS}

Dumitrica et al. (2000) considered Li's Praesaturnalis to be a fragment of a Secuicollacta, However Tetard et al. (2015), examining well preserved examples from the Silurian Arctic argue that Palaeoumbraculum is not a fragment, and by extension Praesaturnalis is unlikely a to be a fragment and should be considered valid.

\section{Procyrtis Li, 1995}

Procyrtis Li, 1995: 336.

TYPe sPeCIES. — Procyrtis rustii Li, 1995 (Li 1995: 336, pl. 1, fig. 17).

Age and location of type Material. - Middle Ordovician, Darriwilian, Qilian Mountains, China.

TAXON CODE. - 157.

STATUS. - Valid.

DiAGNOSIS. — "Test is campanulate or subspindle in outline, network shell, with horn or without. Aperture is open and is not structure of skeleton frame, with four feet. Feet is longer than high of shell as well as three time and feet is fork." (Li 1995: 336).

\section{Tetraedroclathrum Deflandre, 1960}

Tetraedroclathrum Deflandre, 1960: 216.

TYPE SPECIES. - Tetraedroclathrum cabrierense Deflandre, 1960 (Deflandre 1960: 216, pl. 1, fig. 22 [nomen nudum]).

AgE AND LOCATION OF TYPE MATERIAL. — Visean (Carboniferous), Cabrières, Montagne Noire, France.

TAXON CODE. - 158 .

STATUS. - Nomen nudum.

Diagnosis. - None given.

REMARKS

See description of Tetrentactinia Foreman, 1963.

Tlecerina Furutani, 1983

Tlecerina Furutani, 1983: 110.
TYPe SPECIES. - Tlecerina horrida Furutani, 1983 (Furutani 1983: 110, pl. 23, fig. 7 , pl. 24 , fig. $1-3$, pl. 25 , fig. $1-3$ ).

AgE AND LOCATION OF TYPE MATERIAL. - Lower or Middle Devonian, G4 Formation, Mt. Yokokura, Kochi Prefecture, Shikoku, Japan.

TAXON CODE. -159 .

STATUS. — Valid.

DiAgnosis. - "Palaeoscenidiinae containing the spicule in single spherical lattice shell with six to eight, commonly bladed, main spines connecting with rays of the spicule. The principal apical spine is distinct and bladed." (Furutani 1983: 110).

Family PyLentonemidae Deflandre, 1963

Pylentonema Deflandre, 1963

sensu Holdsworth, Jones \& Allison (1978)

Pylentonema Deflandre, 1963: 3981. — Holdsworth et al. 1978: 784.

TYPE SPECIES. - Acanthopyle antiqua Deflandre, 1960 (Deflandre 1960: 216, pl. 1, fig. 14 [nomen nudum]); Deflandre 1963: 3981, fig. 1.

Age And location of type Material. - Visean (Carboniferous), Cabrières, Montagne Noire, France.

TAXON CODE. -160 .

STATUS. - Valid.

ORIGINAL DiAGNOSIS. - "Réunissant les caractères externes d'une coque de Nassellaire-Cyrtellaire (cephalis cornu, ouverture avec podome) aux caractères internes d'un Sphaerellaire-Périaxoplastidié (système fibrillaire rayonnant)" (Deflandre 1963: 3981).

DiAGNOSIS. - "Pylentonemidae with outer shell spherical, pores numerous, closely spaced, simple; pylome circular, surrounded by welldeveloped, but very shallow, circular, unornamented rim. Pylome net (sensu Holdsworth 1973) absent. Pylome rim connecting with one or more of three tricostulate main spines disposed around and adjacent to pylome. Four other tricostulate spines present, none of which approximates to an "apical" spine. Inner spicular system of seven rays arising from the ends of short median bar, each ray connecting with a main spine, the bar and proximal ends of rays sometimes enclosed by small, spherical, inner lattice." (Holdsworth et al. 1978: 784).

\section{Polyentactinia Foreman, 1963 sensu Seo \& Won (2009)}

Polyentactinia Foreman, 1963: 281. — Seo \& Won 2009: 66.

TYPE SPECIES. - Polyentactinia craticulata Foreman, 1963 (Foreman 1963: 281, pl. 5, fig. 3a-b, pl. 9, fig. 5a-b).

Age AND location of TyPe MATERIAL. - Upper Devonian, Huron member, Ohio Shale, USA.

TAXON CODE. -161.

STATUS. - Valid.

DiAGNOSIS. - "A lattice-shell with angular meshes encloses a double spicule with six or more than six rays. This genus differs from Stigmosphaera Haeckel (1887: 68) in that the radial rays do not originate from a central point, but rather from an eccentric median bar. Rüst (1892: 135) used the name Stigmosphaera for a species with six rays 
originating from a central point, a second species in which eight or more rays originate from a central point, and a third in which the rays originate from each end of an eccentric median bar. It seems desirable, however, to restrict the name Stigmosphaera to species falling within Haeckel's original generic definition." (Foreman 1963: 281).

EMENDED DIAGNOSIS. - "A very thin, layered, spongy shell with latticed base opened by a large pylome that has a rounded rim. An internal spicule consisting of seven rays and one thorn-like, very short remnant ray directed to the opening of the pylome." (Seo $\&$ Won 2009: 66).

\section{REMARKS}

Seo \& Won (2009), upon re-examining material from Foreman's locality in Ohio Shale, revised the genus based on their observation that the type species belonged in the Pylentonemidae and was quite different from all of the other taxa assigned to this genus. Consequently, Polyentactinia, which had become something of a "garbage can" taxon, is now a monotypic genus and the remaining species have been reassigned to various genera in the Entactiniidae \& Archaeospicularia.

\section{Quadrapesus Cheng, 1986}

Quadrapesus Cheng, 1986: 121.

TYPE SPECIES. — Quadrapesus dumitricai Cheng, 1986 (Cheng 1986: 121, pl. 2, fig. 11, 15, 23).

Age AND location of type MATERial. - Upper Famennian (Upper Devonian), Woodford Formation, Ouachita Mountains, Oklahoma, USA.

TAXON CODE. -162 .

STATUS. - Valid.

DiAgNOSIS. - "Test as with family but lacking an apical horn. Cephalis small, spherical with a basal aperture, encased within a large, spherical, cortical shell-like thorax; possessing a thin wall with delicate, irregular polygonal pore frames and connected by seven triradiate (axial section) primary radial beams to thorax Thorax spherical with a large, circular basal aperture (pylome) with narrow, slightly elevated pylome rim. Single layer of latticed meshwork with irregular polygonal pore frames. Seven triradiate spines distributed on thorax surface: three on the upper hemisphere; four divergent and slightly curved feet evenly distributed surrounding the pylome margin. No cephalic skeletal elements observed." (Cheng 1986: 121)

\section{Family TetrentactiniIDae Kozur \& Mostler, 1979 Tribe TETRENTACTINIINI}

\section{Ellipsostigma Hinde, 1899}

Ellipsostigma Hinde, 1899a: 51.

TYPE SPECIES. — Ellipsostigma australe Hinde, 1899 (Hinde 1899a: 51, pl. 9, fig. 5).

Age And location of type Material. - Middle Devonian (Givetian), Yarrimie Formation, New South Wales, Australia.

TAXON CODE. -163
STATUS. - Nomen dubium (by Aitchison \& Stratford 1997).

DiAGNOSIS. - "The test is a simple latticed ellipsoid, with four radial spines, which proceed from a central spot or a short bar in the centre of the test. Secondary spines are also present." (Hinde 1899a: 51).

\section{Multisphaera Nazarov \& Afanasieva in Afanasieva, 2000 sensu Dumitrica (2011)}

Multisphaera Nazarov \& Afanasieva in Afanasieva, 2000c: 75. Dumitrica 2011: 208.

TYPE SPECIES. - Multisphaera impersepta Nazarov \& Afanasieva in Afanasieva, 2000 (Nazarov \& Afanasieva in Afanasieva 2000c: 75, pl. 81, fig. 7-10).

Age And location of type Material. - Permian, Urals, Russia.

TAXON CODE. - 164 .

STATUS. - Valid.

DiAGNOSIS. - "Раковина сферическая с четырьмя пористыми оболочками. Внутренний каркас представлен, по-видимому, многолучевой спикулой, продолжением Аучей которой являются многочисленные (более 24) трехгранные основные иглы”. (Nazarov \& Afanasieva in Afanasieva 2000c: 75).

DiAGNOSIS (English translation by P. Dumitrica). — "Test spherical with four porous shells. Innermost skeleton represented, it seems, by a multirayed spicule, whose prolongations result in numerous (more than 24) three-bladed main spines."

EMENDED DIAGNOSIS. - " "Large spherical latticed test originating from an eccentric four-rayed spicule and consisting of a double "medullary shell", a single cortical shell, and one or two intermediary shells. Spicule with a very short, almost invisible median bar and four spines in tetrahedral position. Inside the microsphere rays of the spicule are thick and rod-shaped, while they are three-bladed outside of it. Shells concentric and interconnected by the four primary spines and by a large number of secondary spines originating from the first and especially in the second medullary shell." (Dumitrica 2011: 208)

\section{Somphoentactinia Nazarov, 1975}

Somphoentactinia Nazarov, 1975b: 92; 1975a: 40 (nomen nudum)

TyPE SPECIES. - Tetrentactinia somphozona Foreman, 1963 (Foreman 1963: 283, pl. 7, fig. 6a-b).

Age And location of type Material. - Upper Devonian, Huron member, Ohio Shale, USA.

TAXON CODE. -165 .

STATUS. - Junior synonym of Tetrentactinia (by Won 1997b: table 2).

DiAGNOSIS. — "Внешняя оболочка губчатая, внутренняя - решетчатая, заключаюшая многолучевую спикулу. Внутреняя оболочка может Аибо располагаться на некотором расстоянии от губчатого слоя, мибо соприкасаться с ним”. (Nazarov 1975b: 92).

DiAGNOSIS (English translation of Nazarov [1975b] by E. Roden - in the rad database microfiche collection of Bill Riedel). - The outer shell is spongy, the inner one is latticed and includes a multi-rayed spicule. The inner shell might either lie at a certain distance from the spongy layer or be adjacent to it. 


\section{Spongentactinella Nazarov, 1975}

Spongentactinella Nazarov, 1975b: 91.

TYPE SPECIES. - Tetrentactinia veles Foreman, 1963 (Foreman 1963: 283, pl. 7, fig. 1).

Age AND location of TYPE MATERIAL. - Late Devonian, Carbonaceous concretion Milan 4, Huron member, Ohio Shale, Northern Ohio, USA.

TAXON CODE. -166.

STATUS. - Junior synonym of Tetrentactinia Foreman, 1963 (by Won 1997a: 340).

DIAGNOSIS. - "Внешняя оболочка раковины губчатая, заключаюшая внутри многолучевую спикупу, которая занимает центральное цибо эксцентричное положение." (Nazarov 1975b: 91).

DiAGNOSIS (English translation of Nazarov [1975b] by E. Roden in the rad database microfiche collection of Bill Riedel). - "Cortical shell spongy, including a multi-rayed internal spicule with a central to slightly eccentric position."

\section{Tetrentactinia Foreman, 1963 sensu Maletz (2011b)}

Tetrentactinia Foreman, 1963: 282. — Maletz 2011b: 387

Somphoentactinia Nazarov, 1975b: 92.

Spongentactinella Nazarov, 1975b: 91.

TYPE SPECIES. - Tetrentactinia barysphaera Foreman, 1963 (Foreman 1963: 282, pl. 7, fig. 9).

Age and location of TYPe material. - Upper Devonian, Huron member, Ohio Shale, USA.

TAXON CODE. -167.

STATUS. — Valid.

DESCRIPTION. - "Internal spicule with four rays originating in a point and arranged like the axes of a tetrahedron (tetrahedral spicule), around which is developed a complete or incomplete spherical or subspherical shell, frequently spongy and frequently with secondary spines. The point of union of the rays of the spicule is generally eccentric. The external spines of many of the species are partly or wholly spongy, and this tendency is used as a basis for the inclusion in this genus of a few forms in which the nature of the internal spicule could not be determined. The tetrahedral spicule is the principal distinguishing character of this genus. The only described genus with which Tetrentactinia may be comparable is Ellipsostigma Hinde (1899a, p. 51). The ellipsoidal form of the shell of that monotypic genus may not be sufficient basis for a generic distinction, but the median bar in Hinde's figured specimen does seem to represent a significant difference, and leads one to suspect that the spicule may in fact have had at least six rays. The undescribed genus Tetraedroclathrum Deflandre (1960, p. 216, pl. 1) may be similar to or identical with Tetrentactinia." (Foreman 1963: 282)

\section{REMARKS}

Maletz (2011b) published a detailed discussion on Tetrentactinia Foreman, 1963, which he placed in the Spongentactiniidae Nazarov, 1975 and provided the revised genus diagnosis "Spherical radiolarian with a point-centered, four-rayed spicule and a double-layered shell with a loosely hexagonal mesh structure; a layered and radial three-dimensional meshwork of bars and rays may be present on its surface, forming a 'spongy' mesh; four massive main spines formed from thin round rays as extensions of the spicular rays, surrounded by a relatively dense, fairly regular, radially and concentrically developed meshwork of beams and bars." (Maletz 2011b: 387).

Triaenosphaera Deflandre, 1973

Triaenosphaera Deflandre, 1973c: 1150; 1960: 216 (nomen nudum). Triaenoentactinosphaera Wang, 1997: 155.

TYPe SPECIES. - Triaenosphaera sicarius Deflandre, 1973 (Deflandre 1960: 216, pl. 1, fig. 10 [nomen nudum]; 1973c: 1150, pl. 2, fig. 3-4).

Age And Location of TYPE MATERIAL. - Visean (Carboniferous), Cabrières, Montagne Noire, France.

TAXON CODE. - 168 .

STATUS. - Valid.

DiAGNOSIS. - "Coque sphérique perforée munie de quatre cornes multicostulées, disposées selon les axes d'un tétraèdre" (Deflandre 1973c: 1150).

DiAGNOSIS (English translation by Taniel Danelian). - "Spherical perforated shell bearing four multicostate spines, distributed along the four axes of a tetrahedron."

\section{REMARKS}

"The type species, considered initially as consisting exclusively of a latticed cortical shell with four three-bladed and tetrahedrally placed spines, was found later by Won (1998, pl. 7, fig. 15) to bear an internal shell connected to the cortical one by four tetrahedrally placed rays aligned with the external spines. Unfortunately, this internal shell is rather poorly preserved in the specimen she illustrated, and the magnification of the figure is also too small not only to know the detailed morphology of this shell but also to see the possible remains of a supposed tetrahedral initial spicule. If such a spicule existed in this species, it should have been very thin, fibrillar. If not, the genus should be assigned to the order Spumellaria." (Dumitrica 2011: 210).

\section{Triaenoentactinosphaera Wang, 1997}

Triaenoentactinosphaera Wang, 1997: 155.

TYPE SPECIES. - Triaenoentactinosphaera regularia Wang, 1997 (Wang 1997: 156, pl. 4, fig. 8, 10-12, pl. 5, fig. 20, 21).

Age AND LOCATION of TYPE MATERIAL. - Upper Devonian, Famennian, NW China.

TAXON CODE. -169 .

STATUS. - Junior synonym of Triaenosphaera Deflandre, 1973 (by Won 1998). 
DiAgnosis. - "Two spherical lattice-shells with four three-bladed main spines; medullary shell with four radial beams to join the main spines of outer shell." (Wang 1997: 155).

\section{REMARKS}

This falls within the morphology of Triaenosphaera Deflandre, 1973 and is treated as a junior synonym.

\section{Order LATENTIFISTULARIA}

Caridroit, De Wever \& Dumitrica, 1999

Family CaUletellidae

Caridroit, De Wever \& Dumitrica, 1999

Cauletellidae Caridroit, De Wever \& Dumitrica, 1999: 604.

Deflandrellidae De Wever \& Caridroit, 1984: 98.

Kimagioridae Sugiyama, 2000: 227.

\section{REMARKS}

See Nestell \& Nestell (2010: 36-38), for a summary of the history of the family and genus level taxonomy of genera in Cauletellidae. Herein, we not only include the same taxa as Nestell \& Nestell, but also include Ishigaum and Pseudotormentus in this family, which they place in the Ishigaidae Kozur \& Mostler, 1989.

\section{Cauletella Caridroit, De Wever \& Dumitrica, 1999}

Cauletella Caridroit, De Wever \& Dumitrica, 1999: 608.

Deflandrella De Wever \& Caridroit, 1984: 99.

Kimagior Sugiyama, 2000: 228.

TyPe SPECIES. — Deflandrella manica De Wever \& Caridroit, 1984 (De Wever \& Caridroit 1984: 99, pl. 1, fig. 1-7).

Age and location of type Material. — Upper Permian, Kamigori belt, SW Japan.

TAXON CODE. -170 .

STATUS. - Valid.

DiAgnOSIS. — "Cauletellidae dont l'ensemble de la coque externe est lamelleuse et peu perforée. Les bras se terminent généralement par une petite épine triangulaire, centrale pour un bras, et latérale externe pour les deux autres bras (en vue de face), ce qui définit un plan de symétrie bilatéral, perpendiculaire au plan formé par les bras." (Caridroit et al. 1999: 608).

DiAgnOSIS (English translation by Taniel Danelian). — "Cauletellidae with a completely lamellar shell with few pores. The arms are ended by a small triangular spine, central for one arm and lateral for the other two that creates a bilateral symmetry plan perpendicular to the plane formed by the arms".

Deflandrella De Wever \& Caridroit, 1984

Deflandrella De Wever \& Caridroit, 1984: 99.
TYPE SPECIES. - Deflandrella manica De Wever \& Caridroit (monotypy; De Wever \& Caridroit 1984: 99, pl. 1, fig. 1-7).

Age and location of type material. — Upper Permian, Kamigori Belt, SW Japan.

TAXON CODE. -171 .

STATUS. - Homonym (by Caridroit et al. 1999).

DiAGNOSIS. - " "Deflandrellidae à 3 tubes coplanaires. La position des spicules internes permet la distinction d'un plan de symétrie bilatéral perpendiculaire au plan des bras. Dans ce dernier, l'une des épines émerge du milieu du tube (elle appartient au plan de symétrie bilatérale), les deux autres émergent du bord du tube (du côté le plus éloigné du plan de symétrie). La paroi de la coque est lisse et imperforée ou presque. La structure interne est particularisée par des cloisons transverses réparties régulièrement le long des tubes. Les chambres (ou segments) ainsi délimitées communiquent entre elles par une ou deux petites perforations des cloisons." (De Wever \& Caridroit 1984: 99)

DiAgNosis (English translation by J. P. Caulet - RadWorld database). - "Deflandrellidae with 3 co-planar tubes. The distribution pattern of the internal spines permits to distinguish a plane of bilateral symmetry that is perpendicular to the plane of arms. In this plane, one of the spines outgrows from the middle of the tube (it pertains to the plane of bilateral symmetry), the others outgrow from the rim of the tube (on the farther side to the plane of symmetry). Shell wall smooth and almost not perforate. Internal structure segmented by transversal septa regularly distributed inside the tubes. Chambers (or segments) communicating through one or two small pores in the septa."

\section{REMARKS}

Cauletella is the replacement name because Deflandrella is a junior homonym of the modern plagiacanthid nassellarian Deflandrella Loeblich \& Tappan, 1961. See remarks by Caridroit et al. (1999).

\section{Foremanhelena De Wever \& Caridroit, 1984}

Foremanhelena De Wever \& Caridroit, 1984: 104.

TYPE SPECIES. - Foremanhelena triangula De Wever \& Caridroit, 1984 (De Wever \& Caridroit 1984: 106, pl. 2, fig. 10-18).

Age and location of type material. — Upper Permian, Kamigori belt, SW Japan.

TAXON CODE. -172 .

STATUS. - Valid.

DiAGNOSIS. - "Forme à trois bras coplanaires creux pourvus d'un tissu spongieux distal qui connecte les bras entre eux, formant ainsi une couronne spongieuse. Une petite épine garnit leur extrémité distale. La sphère centrale et la partie proximale des bras sont imperforées." (De Wever \& Caridroit 1984: 104).

Diagnosis (English translation by Taniel Danelian). — "Formed of three hollow coplanar arms with a distal spongy tissue that connects the arms together, forming thus a spongy crown. A small spine garnishes their distal extremity. The central sphere and the proximal part of the arms are imperforate." 


\section{Ishigaum De Wever \& Caridroit, 1984}

Ishigaum De Wever \& Caridroit, 1984: 99.

TYPE SPECIES. — lshigaum trifustis De Wever \& Caridroit, 1984 (De Wever \& Caridroit 1984: 99, pl. 1, fig. 10-13, 16).

Age and location of type material. - Upper Permian, Kamigori belt, SW Japan.

TAXON CODE. - 173 .

STATUS. — Valid.

DiAGNOSIS. - "Formes à trois rayons coplanaires, nus, creux. Imperforés proximalement, ces tubes présentent des pores, étirés, de plus en plus nombreux distalement. Près de l'extrémité distale, un réseau spongieux se développe. Généralement, les bras tubulaires portent une épine distale et sont disposés à $120^{\circ}$ l'un de l'autre." (De Wever \& Caridroit 1984: 99).

Diagnosis (English translation by J. P. Caulet - RadWorld database). - "Shells with three coplanar smooth hollow radii. Proximally imperforate, these radii have elongated pores, more abundant on distal parts. Towards the distal ends, a spongy meshwork. Tubular radii generally with a distal spine and distributed at angles of $120^{\circ}$."

\section{Kimagior Sugiyama, 2000}

Kimagior Sugiyama, 2000: 228.

TyPe SPECIES. - Deflandrella manica De Wever \& Caridroit, 1984 (De Wever \& Caridroit 1984: 99, pl. 1, fig. 1-7).

Age and location of type Material. - Upper Permian, Kamigori Belt, SW Japan.

TAXON CODE. -174 .

STATUS. - Junior synonym of Cauletella Caridroit, De Wever \& Dumitrica, 1999.

DiAgnosis. - See Deflandrella.

\section{REMARKS}

This is a replacement name proposed by Sugiyama (2000) for the homonym Deflandrella De Wever \& Caridroit, 1984, however a replacement name had already been proposed the year before Cauletella by Caridroit et al. (1999).

\section{Praedeflandrella Kozur \& Mostler, 1989}

Praedeflandrella Kozur \& Mostler, 1989: 211.

TYPE SPECIES. — Latentifistula neotenica Nazarov \& Ormiston, 1985 (Nazarov \& Ormiston 1985: 33, pl. 3, fig. 11, text-fig. 8).

Age and location of type material. - Artinskian (Lower Permian), Don village, Ural River, Southern Urals, Russia.

TAXON CODE. -175.
STATUS. - Valid.

DiAgNOSIS. - "Mit den Familienmerkmalen. Arme sehr schlank. Zentralfeld und proximaler Abschnitt der Arme unperforiert, sonst meist perforiert, selten unperforiert. Keine Kammerung der Arme durch Querwände.” (Kozur \& Mostler 1989: 211).

Diagnosis (English translation by J. P. Caulet - RadWorld database). - "With the characteristics of the family [Deflandrellidae De Wever \& Caridroit, 1984, renamed Cauletellidae by Caridroit et al. (1999: 606)]. Arms very slender. Central area and proximal parts of the arms imperforate, other parts often perforate, rarely imperforate. No transversal walls in arms."

\section{REMARKS}

Nestell \& Nestell (2010: 38) consider this a separate genus from Shangella Feng in Feng, He, Zhang \& Gu, 2006, and we maintain it as a valid genus based on their arguments.

\section{Pseudotormentus De Wever \& Caridroit, 1984}

Pseudotormentus De Wever \& Caridroit, 1984: 101.

TYPe SPECIES. - Pseudotormentus kamigoriensis De Wever \& Caridroit, 1984 (De Wever \& Caridroit 1984: 101, pl. 2, fig. 1-7).

Age and location of type material. - Upper Permian, Kamigori belt, SW Japan.

TAXON CODE. -176 .

STATUS. - Valid.

DiAGNOSIS. - "Latentifistulidae à trois bras tubulaires coplanaires. Distalement, ceux-ci sont entourés d'un réseau fait de 6-8 poutres longitudinales et de trabécules transverses qui les joignent. Le réseau évoque fortement celui des Hagiastridae. " (De Wever \& Caridroit 1984: 101).

DiAGNOSIS (English translation by J. P. Caulet - RadWorld database). Latentifistulidae with three coplanar tubular arms. Distal ends of arms surrounded by a meshwork of 6-8 longitudinal beams and transverse trabeculae. Meshwork similar to the meshwork of Hagiastridae.

\section{Shangella Feng in Feng, He, Zhang \& Gu, 2006}

Shangella Feng in Feng, He, Zhang \& Gu, 2006b: 828.

TyPe SPECIES. - Shangella longa Feng in Feng, He, Zhang \& Gu, 2006 (Feng et al. 2006b: 829, fig. 6.6, 6.7, 6.9-6.15).

Age AND location of tyPE MATERIAL. - Upper Changhsingian (uppermost Permian), Southern Guangxi, China.

TAXON CODE. -177 .

STATUS. — Valid.

DiAGNOSIS. - " "Test consists of three coplanar arms, and the arm hollow, tubular, with regularly arranged pores and quickly inflated end." (Feng in Feng et al. 2006b: 828).

\section{REMARKS}

Following Nestell \& Nestell (2010) we include this genus in the Cauletellidae. 
Triactofenestrella Nazarov \& Ormiston, 1984

Triactofenestrella Nazarov \& Ormiston, 1984: 79.

TyPE SPECIES. - Triactofenestrella nicolica Nazarov \& Ormiston, 1984 (Nazarov \& Ormiston 1984: 79, pl. 5, fig. 4-5).

AgE AND LOCATION OF TYPE MATERIAL. - Upper Carboniferous Gzhelian, south Urals.

TAXON CODE. -178 .

STATUS. - Junior synonym of Latentibifistula Nazarov \& Ormiston, 1983 (by De Wever et al. 2001).

DiAGNOSIS. - “Очень крупные Latenofistulidae, имеющие пористую внутреннюю сферу. Под углом $120^{\circ}$ от нее отходят 3 массивных внутренних куча, пронизанных порами. В свою очередь перекладины, отходящие от узцов межпоровой решетки, разветвцяются и, соединяясь между собой, образуют сетчато-губчатую внешнюю оболочку". (Nazarov \& Ormiston 1984: 79).

DiAgnosis (English translation by J. P. Caulet - RadWorld database). - "Very large Polycystine with an internal porous sphere, from which diverge at angles of $120^{\circ}$ three robust perforated rays. From them (at the nodes of the inter-pore frames) originate robust bars that branch and merge to constitute the external envelope of the triangular shell."

\section{REMARKS}

In their summary statement about Triactofenestrella Nazarov $\&$ Ormiston (1984: 87) write that it "is distinguished by its rather large inner sphere (up to $110 \mu \mathrm{m}$, rather than 45 to $50 \mu \mathrm{m}$ as in other Latentifistulid genera)." The dimensions of the inner sphere for the type species of Latentibifistula were not given in order to substantiate this difference, but comparison of external morphology shows the type species for each genus to by quite comparable in size, shape, width of arms and of the exterior layer. De Wever et al. (2001) consider this genus to be a junior synonym to Latentibifistula.

\section{Trifidospongus Noble \& Renne, 1990}

\section{Trifidospongus Noble \& Renne, 1990: 388.}

TYPe SPECIES. - Trifidospongus dekkasensis Noble \& Renne, 1990 (Noble \& Renne 1990: 388, pl. 1, fig. 1-3, 6).

AgE AND LOCATION OF TYPE MATERIAL. — Permian, eastern Klamath mountains, USA.

TAXON CODE. -179 .

STATUS. - Junior synonym of Triplanospongos Sashida \& Tonishi, 1988.

DiAGNOSIS. - "Trilobate to triradiate test of coarse spongy material surrounding an inner trifurcating structure comprised of two thickened bars running parallel to subparallel down center of ray. Bars merge with spongy cortex at distal end of rays. Cross sections of rays are ovate. Pores are subcircular to polygonal. The two primary bars are connected by a series of smaller more delicate secondary bars which run perpendicular like rungs of a ladder. Secondary bars are not well preserved in the type material. Rays end in a terminal spine. Spongy cortex is comprised of multiple stacks of porous framework. Pores are arranged linearly and meet at equant triplejunctions. Bars which comprise the pore frames are of consistent thickness and don't swell into nodes at their juncture nor become flattened." (Noble \& Renne 1990: 388).

\section{REMARKS}

The publication of Sashida \& Tonishi (1988) predated that of Noble \& Renne (1990) making this the junior synonym.

Triplanospongos Sashida \& Tonishi, 1988

Triplanospongos Sashida \& Tonishi, 1988: 536.

Trifidospongus Noble \& Renne, 1990: 388.

TYPe SPECIES. - Triplanospongos musashiensis Sashida \& Tonishi, 1988 (Sashida \& Tonishi 1988: 536, fig. 6, 9.7-9.12 [monotypy]).

Age and location of type Material. - Upper Permian, Itsukaichi, Tokyo Prefecture, Japan.

TAXON CODE. - 180 .

STATUS. — Valid.

DiAGNOSIs. - "Shell comprising three double-ridged arms with triangular spongy fabrics and conical terminal spines. Arms radiating from the center of shell at an angle of $120^{\circ}$. Small triradiate plate present at the center of shell. One or two narrow ridges, I-shaped in cross section, being arranged parallel to arm at nearly mid-part of spongy shell. This ridge coming in contact with arm at distal end of shell or amalgamated [sic, probably amalgamate] with surrounding spongy fabrics." (Sashida \& Tonishi 1988: 536).

Family LATENTIFISTULIDAE Nazarov \& Ormiston, 1983

Ouakidae Cheng, 1986: 175.

Archaeopyramisidae Cheng, 1986: 179.

REMARKS

As defined by De Wever et al. (2001: 101) these taxa are "Latentifistularia with an initial spicule with one apical and two or three basal spines, and a perforate to slightly perforate microsphere". Housed in this family are 3 to 4 rayed lobate forms, excluding the triangular forms placed in the Ruzhencevispongidae. Following De Wever in part, we include Latentifistula, Areolicaudatus and Brianellium, but we reassign Archaeopyramisa, and Wonia to other families. We also include other the lobate or radiate forms Latentibifistula, Staurentactinia.

Cheng (1986) erected the superfamily Archaeopyramisidae to house his stauraxon radiolarian taxa from the Ouchita and Arbuckle mountains. He found that these taxa possessed a "labyrinthine" structure, which consists of a loose spongy meshwork composed of "hollow bars intricately interlacing to form an irregular pore frame" Superficially, these taxa appear to have what Cenozoic workers would term a loose spongy wall structure, however, the big distinction is the hollow nature of the bars. In the Lower Paleozoic a different use of the term labyrinthine is adopted to describe a similar mesh construc- 
tion but lacking the hollow bars; (e.g. MacDonald 1998; Won et al. 2002; Jones \& Noble 2006; Maletz \& Bruton 2007). Cheng is the only researcher to have reported hollow bars in the upper Paleozoic stauraxon taxa, and thus we are inclined to expect that this detailed structure is either a preservational artifact, or a feature rarely preserved in other spongy taxa. We do not treat the hollow nature of the bars as a criterion that merits erecting a new superfamily. We follow De Wever et al. (2001) in treating the Ouakidae and Archaeopyramisidae as a junior synonyms to Latentifistulidae.

\section{Areolicaudatus \\ Feng \& Liu, 1993}

Areolicaudatus Feng \& Liu, 1993b:545. — Feng 1992: 56. (nomen nudum).

TyPe SPECIES. - Areolicaudatus semiglobosus Feng, 1992 (nomen nudum; Feng 1992: pl. 1, fig. 11); Feng \& Liu 1993b: 545, pl. 1, fig. 11-13.

AgE AND LOCATION OF TYPE MATERIAL. - Upper Maokouan to lower Upper Permian (Follicucullus Assemblage Zone), South and Southwest China.

TAXON CODE. -181 .

STATUS. — Valid.

DiAGNOSIS. 一 “壳由顶角、头和尾三部分组成, 顶角发育, 圆 锥形; 头半球形, 近球形; 头和顶角具微小的孔. 尾近柱形, 为 网状空心管, 网由强状的纵向棒和纤细的横向杆交织形成, 纵向棒位于外侧, 横向杆位于内侧” (Feng \& Liu 1993b: 545).

DiAGNOSIs (English translation). — " "Shell with four arms disposed on a tetrahedral model. Three coplanar arms long; each arm an elongate meshwork tube with inflated spongy end and with terminal spine; meshwork tube built with more than five longitudinal beams joined by transverse bars. Narrow fourth arm." (Feng et al. 2006b: 845, 846).

\section{Brianellium Cheng, 1986}

Brianellium Cheng, 1986: 180.

TyPE SPECIES. - Brianellium holdsworthi Cheng, 1986 (Cheng 1986: 182, pl. 3, fig. 13, 14, 17, 23).

AgE AND LOCATION OF TYPE MATERIAL. - Lower Carboniferous, Oklahoma and Arkansas, USA.

TAXON CODE. -182 .

STATUS. - Valid.

DiAGNOSIS. - “Test composed of four rays extending from a central sphere forming a tetrahedral or pyramid-like structure. Inter-radial angles between any two rays equal to or close to $120^{\circ}$. Central sphere differentiated into a cortical shell and a medullary shell. Wall structure of cortical shell is labyrinthine in pattern consisting of intricately interlacing, relative thin bars, which form an irregular, loose, spongy meshwork. Centrally placed medullary shell, usually relatively small in size, spherical to subspherical in shape, consisting of a latticed wall with polygonal pore frames. Four primary beams connected between medullary shell and cortical shell, originating from the wall surface of the medullary shell, equally positioned and extending through the central sphere, continuous with tip of four rays forming four spines. Rays cylindrical with loosely spongy wall structure, circular in axial section." (Cheng 1986: 180).

\section{REMARKS}

The gross external structure of this form shows variation from sub pyramidal to quadrilobate, and in some ways is similar to Quadrilobus, and less to Tetratormentum. Based on these observations we do not follow De Wever et al. (2001) in treating this genus as a junior synonym to Tetratormentum, and leave the species as valid until additional analysis can be performed on material of this age. The description of a spherical to subspherical medullary shell and 4 rays fits within the definition of the family Latentifistulidae sensu De Wever et al. (2001), although placement in the Pseudolithellidae may also be appropriate.

\section{Latentibifistula Nazarov \& Ormiston, 1983}

Latentibifistula Nazarov \& Ormiston, 1983b: 373.

Triactofenestrella Nazarov \& Ormiston, 1984: 79.

TYPE SPECIES. - Latentibifistula triacanthophora Nazarov \& Ormiston, 1983 (Nazarov \& Ormiston 1983b: 374; pl. 1, fig. 4-5). Note: holotype never figured, paratype, pl. 1, fig. 4 .

Age and location of TyPe Material. - Sakmarian (Lower Permian), Don village, Ural River, Southern Urals, Russia.

TAXON CODE. -183 .

STATUS. — Valid.

DiAgNOSIS. - "Latentifistulidae with internal framework in the form of an imperforate sphere with three hollow rays, radiating at angles of about $120^{\circ}$. Internal framework enclosed in a two-layered spongy or porous skeletal fabric." (Nazarov \& Ormiston 1983b: 373).

\section{Latentifistula Nazarov \& Ormiston, 1983 sensu Maldonado \& Noble (2010)}

Latentifistula Nazarov \& Ormiston, 1983b: 371. — Maldonado \& Noble 2010: 88.

Ouaka Cheng, 1986: 176.

Trilacertus Cheng, 1986: 177.

Wonella Kozur \& Mostler, 1989: 220.

TyPe SPECIES. - Latentifistula crux Nazarov \& Ormiston, 1983 (Nazarov \& Ormiston 1983b: 372, pl. 1, fig. 1).

Age AND location of type material. - Lower Asselian (Lower Permian), Nikol village, Ural River, Southern Urals, Russia.

TAXON CODE. -184 .

STATUS. — Valid.

DiAGNOSIS. - "Latentifistulidae having an internal framework in the form of a non-porous sphere with three hollow, short rays. These rays usually radiate from the sphere at angles of $120^{\circ}$, producing the 
same cruciform arrangement of the skeleton. The internal framework is enclosed by a spongy-porous or platy shell. Terminal spines connected by thin rods to the internal hollow rays, well expressed in one species and lacking in others." (Nazarov \& Ormiston 1983b: 371).

\section{REMARKS}

The type species is from the Permian of west Texas, but also included in this genus are Mississippian forms, including Latentifistula (Paronaella) impella Ormiston \& Lane, 1976. Holdsworth \& Murchey (1988: 784-786) assert that the Mississippian stauraxon radiolarians, which include most of those assigned to Latentifistulida by Nazarov \& Ormiston (1983b, 1985, 1986, 1992) possess solid rectilinear axial filaments inside the rays, connected to a perforate sphere. This observation is contrary to the above definition that describes the rays as hollow tubes and the inner sphere as perforate. In the type species, Latentifistula crux, a younger (Lower Permian) species, axial filaments extend through the majority of the length of the rays, and the hollow tube is very short, present only in the proximal $30 \mu \mathrm{m}$ of the ray that extends from the sphere. Meanwhile, Won (1983) established Scharfenbergia, and included several of the taxa assigned to Latentifistula, but with a type species based on a triangular form demonstrably without hollow rays. In their revision of the genus, Kozur \& Mostler (1989) restrict Latentifistula to triradiate and trilobite forms, and move $\mathrm{Pa}$ ronaella impella to a new genus Wonella. Nestell \& Nestell (2010) provide a nice review of the history of these taxa, and essentially adopt the definition of Kozur \& Mostler (1989), except that they also include Wonella as a junior synonym. Maldonado \& Noble (2010) largely concur with Nestell \& Nestell (2010), except they use a more expanded definition that incorporates forms that have three or occasionally four rays. This definition includes two Carboniferous genera described by Cheng (1986), Ouaka, Trilacertus. Both of Cheng's genera are from his superfamily Archaeopyramacea, which reportedly has a distinct wall architecture described as labyrinthine (see comments under respective genera and the family Latentifistulidae). Thus, the current usage of Latentifistula incorporates trilobate and triradiate forms, occasionally with a $4^{\text {th }}$ ray, that have a central sphere that appears either porous or non-porous, and rays or beams that emanate from the sphere inside the arms. These rays may be hollow and/or a latticed extension of the inner sphere (termed a medullary shell by Cheng) and connect distally to a solid thin axial ray.

\section{Ouaka Cheng, 1986}

Ouaka Cheng, 1986: 176.

TYPE SPECIES. - Ouaka asymmetrica Cheng, 1986 (Cheng 1986: 176, pl. 2, fig. 1, 2, 11, 13, 18).

Age AND location of TYPe MATERIAL. - Lower Carboniferous, Oklahoma and Arkansas, USA.

TAXON CODE. -185
STATUS. - Junior synonym of Latentifistula Nazarov \& Ormiston, 1983b (by Maldonado \& Noble 2010).

DiAgNosis. - "Test as with family, but composed of three symmetrically to slightly asymmetrically arranged rays occurring in a single plane. Cortical shell of central area and rays composed of labyrinthine meshwork with thin, hollow, intricately interlacing bars forming irregularly shaped pores. Rays discoid in cross section. Medullary shell composed of a centrally placed latticed shell and three longitudinal, hollow, radial beams. Longitudinal radial beams asymmetrically surround the central medullary shell along three edges and radially extend through the interior of the rays. Radial beams appear to be continuous with ray spines. Latticed medullary shell and radial beams connected by secondary radial beams to the cortical shell.” (Cheng 1986: 176).

\section{REMARKS}

Many elements of the above diagnosis are common to that of the original description of Latentifistula, including "hollow radial beams", which may be construed as the hollow rays described in Latentifistula by Nazarov \& Ormiston (1983b). We do not recognize the "labyrinthine" structure sensu Cheng (1986) as a distinction from other stauraxon genera (see remarks under the family Latentifistulidae)

\section{Staurentactinia Schwartzapfel \& Holdsworth, 1996}

Staurentactinia Schwartzapfel \& Holdsworth, 1996: 202.

TYPE SPECIES. - Staurentactinia nazarovi Schwartzapfel \& Holdsworth, 1996 (Schwartzapfel \& Holdsworth 1996: 202, pl. 9, fig. 1-2, 5-19).

Age and location of type material. - Upper Famennian (Upper Devonian), Woodford Formation, Criner Hills and Arbuckle Mountains, Oklahoma, USA.

TAXON CODE. -186 .

STATUS. - Valid.

DiAGNOSIS. - "Test composed of four arms tetrahedrally aligned, extending radially outwards from corners of a central sphere. Test differentiated into an external (cortical) shell and an internal system of four entactiniid spicule rays. External (cortical) shell having a spongy meshwork, variable in density; consisting of thin, irregularly interwoven, solid bars and variably sized/shaped pores. Four solid internal spicular rays connected together at a single point within central interior of central sphere. Spicular rays extend through interior of central sphere and central portion of arms; appearing to be continuous with terminal spines at arm tips. Arms subcylindrical to cylindrical, circular in axial section." (Schwartzapfel \& Holdsworth 1996: 202).

\section{Trilacertus Cheng, 1986}

Trilacertus Cheng, 1986: 177.

TYPe SPECIES. - Trilacertus baumgartneri Cheng, 1986 (Cheng 1986: 178, pl. 2, fig. 4, 8, 10, 12, 16, 19).

Age AND location of TYPE MATERIAL. - Lower Carboniferous, Oklahoma and Arkansas, USA.

TAXON CODE. -187 
STATUS. - Junior synonym of Latentifistula Nazarov \& Ormiston, 1983b (by Maldonado \& Noble 2010).

DiAgnOSIS. - "Test as with family composed of three rays occurring in a plane. Cortical shell composed of labyrinthine meshwork with hollow bars and irregular pores. A "patagiumlike" structure may or may not be present between rays forming a triangular outline. Medullary shell composed of centrally placed, discoidal latticed shell and a medullary ray. Medullary rays composed of latticed meshwork with hollow bars and predominately elliptical pores; rays circular in axial section, forming an elongate canal along the ray axis. Medullary rays sometimes merging at distal portion of ray, naked without cortical shell, surrounding and appearing to be continuous, terminating in solid spine of cortical shell. Latticed central medullary shell and medullary rays connected by secondary radial beams to cortical shell.” (Cheng 1986: 177).

\section{REMARKS}

Cheng's specimens of Trilacertus look like exceptionally well preserved examples of the Carboniferous genus Latentifistula and are included herein. See remarks under Latentifistula.

\section{Wonella Kozur \& Mostler, 1989}

Wonella Kozur \& Mostler, 1989: 220.

TyPe SPECIES. - Paronaella impella Ormiston \& Lane, 1976 (Ormiston \& Lane 1976: 169, pl. 3, fig. 1-5).

AgE AND LOCATION OF TYPE MATERIAL. - Lower Carboniferous, Cis-Urals, Russia.

TAXON CODE. -188 .

STATUS. - Junior synonym of Latentifistula Cheng (by Nestell \& Nestell 2010).

DiAGNOSIs. - "Mit den Familienmerkmalen. Gehäuse dreiarmig, ohne dreieckiges Mittelskelett. Struktur grobschwammig". (Kozur \& Mostler 1989: 220).

DiAgNOSIS (English translation by J. P. Caulet - RadWorld database). - "With the characteristics of the family. Three arms, no triangular median part. Structure coarsely spongy."

\section{REMARKS}

Wonella was placed in synonymy with Ouaka by Dumitrica in De Wever et al. (2001) because its morphology and skeletal structure are rather similar to those of Ouaka. Nestell \& Nestell (2010) include Wonella in Latentifistula, and Maldonado \& Noble (2010) consider Wonella, Ouaka, and Latentifistula to be synonymous.

Family Ormistonellidae De Wever \& Caridroit, 1984 sensu Dumitrica in De Wever et al. (2001)

Cornellus Kozur \& Mostler, 1989

Cornellus Kozur \& Mostler, 1989: 212.

TYPE SPECIES. - Cornellus sakmaraensis Kozur \& Mostler, 1989 (Kozur \& Mostler 1989: 213, pl. 10, fig. 1, 2, 4).
Age and location of type Material. - Sakmarian, Lower Permian, Cis-Urals, Russia.

TAXON CODE. - 189 .

STATUS. - Junior synonym of Polyfistula (by De Wever et al. 2001).

DiAGNOSIS. - "Das Außenskelett besitzt einen discoidalen Zentralteil, von dem 8 lange, sehr schlanke, hohle Arme in Äquatorebene ausstrahlen, die in ihrer ganzen Länge etwa gleich breit bleiben. Ein neunter, ebenfalls langer, sehr schlanker, hohler Arm entspringt im Zentrum des Zentralteils des Außenskeletts und steht etwa senkrecht auf der Ebene der übrigen Arme. Das Außenskelett weist sowohl im Zentralteil als auch auf den Armen ziemlich große Poren auf, die meist weit getrennt stehen. Dort, wo das Innenskelett entlang der Wand des Außenskeletts verläuft, sind die Poren beiderseits in Längsreihen angeordnet, in denen sie dicht aufeinander folgen. Das Innenskelett besteht aus einer unperforierten Markschale, von der so viele Arme ausstrahlen, wie Arme im Außenskelett vorhanden sind. Diese Arme des Innenskeletts sind rinnenförmig eingesenkt und verlaufen entlang der Wandung des Außenskeletts, von der sie aber strukturell deutlich abgesetzt sind. Vielfach verlaufen sie innerhalb der Wandung schräg in Form einer angedeuteten Spirale." (Kozur \& Mostler 1989: 212).

Diagnosis (English translation by J. P. Caulet - RadWorld database). - "External shell constituted by a discoidal central part with 8 long, very slender, hollow arms of nearly the same width all along their length, and distributed in the equatorial plane. A ninth, longer, very slender, hollow arm arises from the centre of the central part of the external skeleton, vertically to the plane of the other arms. Rather large pores on the central part and on the arms of the external shell, usually well separated. At the junction between the inner structure and the wall of the external shell, pores distributed, on both sides, in long, dense, rows. Inner structure constituted by an imperforate medullary shell with four arms related to the arms of the external shell. These inner arms are gutter-shaped and developed along the wall of the external shell from which they structurally differ. They are often obliquely developed inside the wall as an approximate spiral."

\section{REMARKS}

Images of type species of both Cornellus and Polyfistula show the same distinct array of long hollow arms arranged in a plane, with one ray occurring perpendicular. The diagnosis of Cornellus provides more detail that can be observed in specimens of Polyfistula.

\section{Haploaxon Cordey, 1998}

Haploaxon Cordey, 1998: 52.

TyPE SPECIES. - Haploaxon merrittensis Cordey, 1998 (Cordey 1998: 53, pl. 9, fig. 8).

Age And location of type material. - Artinskian, lower Permian, Canada.

TAXON CODE. -190 .

STATUS. — Valid.

DiAGNOSIS. - "Test à symétrie axiale de forme allongée composé des trois parties suivantes. (1) Une partie apicale conique terminée ou non par une corne. Cette partie est constituée d'un reseau 
treillissé de cadres de pores polygonaux; les pores qui en resultent sont circulaires ou polygonaux. (2) Une partie médiane en forme de disque épais dont le diamètre est d'environ trois fois celui de la partie apicale. Elle est constituée exterieurement par une paroi treillissée de cadres de pores circulaires en section axiale. Les pores sont de taille variable, géneralement circulaires; les intersections des cadres de pores sont de petites nodosités, parfois pointues. Cette paroi se fixe sur un réseau treillissé interne de cadres de pores plus fins et plus courts; l' épaisseur de ce reseau ainsi que la structure interne du test n' ont pas été observées. (3) Une partie terminale (ou distale) constituée d'un long tube creux situé dans l'axe des deux parties précédentes. Son diametre est généralement constant. Il est constitué de poutres ou de plaques longitudinales reliées par des trabécules; des pores circulaires ou ellipsoidaux sont ainsi délimités." (Cordey 1998: 52).

DiagnOSIS (English translation by Paula Noble and Fabrice Cordey). - "Test axially symmetric with an elongated shape composed of the following three parts (1) A conical apical part with or without a horn. This part consists of a latticed network with polygonal pore frames; the resulting pores are circular or polygonal. (2) A middle part in the form of a thick disc, the diameter of which is about three times that of the apical part. It is composed externally of a latticed wall of rounded pore frames in cross section. The pores are of variable size, generally circular; the intersections of the pore frames are small nodes, sometimes pointed. This wall is then attached to a finer and shorter latticed internal pore frame; the thickness of that network thus the internal structure of the test was not observed. (3) A terminal (or distal) part consisting of a long hollow tube positioned along the axis of the two preceding parts. Its diameter is generally constant. It consists of beams or longitudinal plates connected by trabeculae ; circular or ellipsoidal pores are delimited."

\section{REMARKS}

The type material is a fragment (arm) with a long robust longitudinal bar, which indicates its affinity with latentifistulids close to others in the Ormistonellidae. Since the type material is fragmentary, we do not know the number of arms. Future work on this material may indeed indicate synonymy with another ormistonellid.

\section{Nabespecha Cornell \& Simpson, 1986}

Nabespecha Cornell \& Simpson, 1986: 286.

Type SPECIES. - Nabespecha leonardia Cornell \& Simpson, 1986 (Cornell \& Simpson 1986: 286, pl. 1, fig. 1-4).

AgE AND LOCATION OF TYPE MATERIAL. — Permian, West Texas, USA.

TAXON CODE. - 191 .

STATUS. - Junior synonym of Polyfistula (by Noble \& Renne 1990: 387).

DiAGNOSIS. - "Subradial to bilaterally symmetrical radiolarians whose central disc region is approximately circular in plan view and a compressed cone in side view. Seven to ten long, slender rays, more or less symmetrically arranged, radiate from the central disc." (Cornell \& Simpson 1986: 286).

Nazarovella De Wever \& Caridroit, 1984
TYPE SPECIES. - Nazarovella gracilis De Wever \& Caridroit, 1984 (De Wever \& Caridroit 1984: 101, pl. 1, fig. 14-15, 17).

Age and location of type material. - Upper Permian, Kamigori Belt, SW Japan.

TAXON CODE. -192 .

STATUS. - Homonym of the Triassic radiolarian Nazarovella Kozur \& Mostler, 1979 (replacement name Raciditor by Sugiyama [2000]); and Junior synonym of Quadricaulis Caridroit \& De Wever, 1986 (herein).

DiAGNOSIS. - "Formes à 4 appendices inégaux disposés selon un modèle tétraédrique; 3 sont bien développés, le quatrième est petit. La partie centrale a une forme de tétraèdre globuleux." (De Wever \& Caridroit 1984: 101)

Diagnosis (ENGLiSH TRANSLATION BY J. P. Caulet - RadWorld database). — "Shells with 4 unequal appendices distributed following a tetrahedral pattern; 3 of them are well-developed, the fourth being small. Central part displays a globular tetrahedral shape".

\section{REMARKS}

We treat this genus as a junior synonym of Quadricaulus because the holotype appears to be a broken specimen of Quadricaulus, and the unequal size of the $4^{\text {th }}$ arm a result of that breakage.

\section{Ormistonella De Wever \& Caridroit, 1984}

Ormistonella De Wever \& Caridroit, 1984: 100.

TYPE SPECIES. — Ormistonella robusta De Wever \& Caridroit, 1984 (De Wever \& Caridroit 1984: 100, pl. 2, fig. 8-9).

Age and location of type material. - Upper Permian, Kamigori belt, SW Japan.

TAXON CODE. - 193.

STATUS. - Valid.

SynONyM. - Paulianella Kozur \& Mostler, 1989.

DiAgNOSIS. - "Ormistonellidae à 4 bras également développés, longs, en forme de tube et/ou de gouttière." (De Wever \& Caridroit 1984: 100).

DiAgNosis (English translation by J. P. Caulet - RadWorld database). - "Ormistonellidae with 4 arms equally developed, long, tube and/or gutter shaped."

\section{Paulianella Kozur \& Mostler, 1989}

Paulianella Kozur \& Mostler, 1989: 215.

TYPE SPECIES. - Latentifistula valdeinepta Nazarov \& Ormiston, 1985 (Nazarov \& Ormiston 1985: 33; holotype never figured, paratype pl. 3, fig. 9-10).

Age and location of type Material. - Lower Permian, Sakmarian Stage, Kandurov Suite, Southern Urals, Sakmar River, Verkhnay Chernaya Rechka Village, Russia.

TAXON CODE. -194. 
STATUS. - Junior synonym of Ormistonella De Wever \& Caridroit, 1984 (by De Wever et al. 2001).

DiAgnOSIS. - [As for family] Diagnosis of the Family Paulianellidae: "Dreiarmig. Arme sehr schlank, mit einer Längsfurche, in der eine Porenreihe auftritt. Sonst ist die einschichtige Schale unperforiert. Das Innenskelett besteht aus einer unperforierten Markschale, die einzelne Stacheln aufweist. Von ihr gehen 3 breite, hohle, sehr kurze Arme aus, die zur Wand des Zentralteils des Außenskeletts zwischen den Armen des Außenskeletts verlaufen. Diese Arme des Innenskeletts sind aus völlig miteinander verschmolzenen Stachelbüscheln aufgebaut und sie weisen je eine große Pore auf. In den Armen tritt kein Innenskelett auf. Das Ende der Arme ist gerundet und weist keine Terminalstacheln auf." (Kozur \& Mostler 1989: 215).

DiAGNOSIS (English translation by J. P. Caulet - RadWorld database). — "Three arms. Arms slender with a longitudinal depression including a row of pores. Single layered shell otherwise imperforate. Internal framework constituted by an imperforate medullary shell with a single spine. From the shell arise 3 wide, hollow, short arms extending out to the wall of the central part of the external skeleton between the arms. These arms are built by a bundle of completely joined spines with a large pore. Arms with no internal skeleton. Ends of arms blunt with no terminal spines."

\section{REMARKS}

The diagnosis of Ormistonella describes 4 arms not 3, as in Paulianella, but examination of the photo of Ormistonella in Kozur \& Mostler, 1989 shows that it is broken so that the $4^{\text {th }}$ arm is missing. The morphology of the arms is the same, and we follow De Wever et al. (2001) in considering Paulianella a junior synonym of Ormistonella.

\section{Polyfistula Nazarov \& Ormiston, 1984}

Polyfistula Nazarov \& Ormiston, 1984: 80.

Nabespecha Cornell \& Simpson, 1986: 286.

Cornellus Kozur \& Mostler, 1989: 212.

TYPe SPECIES. - Polyfistula longiquitas Nazarov \& Ormiston, 1984 (Nazarov \& Ormiston 1984: 80, pl. 5, fig. 10).

Age and location of type Material. - Artinskian, Lower Permian, Urals, Russia.

TAXON CODE. - 195.

STATUS. — Valid.

DiAGNOSIS. — "Latentofistulidae? с многочисленными (7 и более) кучами внутреннего каркаса, которые заключены в пластинчатую, неперфорированную скеметную ткань внешних удииненных мопастей”. (Nazarov \& Ormiston 1984: 80).

DiAgnOSIS (English translation by J. P. Caulet - RadWorld database). - "Latentifistulidae? with an internal structure composed of numerous rays (7 or more rays), emanating from a hollow sphere of a diameter of $40-45 \mu \mathrm{m}$. Usually, six, and more, rays are distributed in the same plane, another one being perpendicular to them. Internal structure enclosed by the plate-like tissue of the externally elongated lobes." (Nazarov 1988: 80).
Quadricaulis Caridroit \& De Wever, 1986

Quadricaulis Caridroit \& De Wever, 1986: 79.

Nazarovella De Wever \& Caridroit, 1984: 101 (n. syn.)

Quadriremis Nazarov \& Ormiston, 1985: 36 (n. syn.)

Raciditor Sugiyama, 2000: 227.

TyPe SPECIES. — Quadricaulis femoris Caridroit \& De Wever, 1986 (Caridroit \& De Wever 1986: 79, pl. 4, fig. 16-19).

Age and location of type Material. - Upper Permian, Tatsuno Formation, Hyogo Prefecture, southwest Japan.

TAXON CODE. - 196.

STATUS. - Valid.

DiAgNOSIS. - "Latentifistulidae with four long equal arms disposed on a tetrahedral structure. The inner framework is a central sphere with four radiating rays having a gutter shape (at least for the proximal part). This inner frame is totally enclosed in a spongy or perforated shell." (Caridroit \& De Wever 1986: 79).

\section{Quadriremis Nazarov \& Ormiston, 1985}

Quadriremis Nazarov \& Ormiston, 1985: 36.

TYPE SPECIES. - Quadriremis gliptoacus Nazarov \& Ormiston, 1985 (Nazarov \& Ormiston 1985: 36, pl. 4, fig. 8-9, text-fig. 9a-b; holotype never figured, paratype pl. 4, fig. 8).

Age and location of type material. - Lower Permian, Artinskian Stage, Aktastinian Substage, Southern Urals.

TAXON CODE. - 197.

STATUS. - Junior synonym of Quadricaulis Caridroit \& De Wever, 1986 (herein).

DiAGNOSIS. - "Latentifistulidae with internal framework forming a nonporous sphere with four hollow rays. Three rays usually emerging from sphere at $120^{\prime}$ with fourth ray perpendicular to that grouping. Internal framework enclosed in platy, platy latticed or, rarely, a spongy shell. Terminal spines connected with rays of internal framework by thin rods." (Nazarov \& Ormiston 1985: 36).

\section{REMARKS}

This taxon is commonly found as fragments because of its size and delicate rays. The most complete representatives are figured and included under the genus Quadriremis, but are just better preserved and more complete specimens of Quadricaulis Caridroit \& De Wever, 1986

\section{Quinqueremis Nazarov \& Ormiston, 1983}

Quinqueremis Nazarov \& Ormiston, 1983b: 374.

TYPE SPECIES. - Quinqueremis arundinea Nazarov \& Ormiston, 1983 (Nazarov \& Ormiston 1983b: 375, pl. 1, fig. 6-7; holotype never figured, paratype, pl. 1, fig. 7).

Age and location of type material. - Artinskian, Lower Permian, Little Suren River, Bashkiria, Southern Urals, Russia. 
TAXON CODE. -198

STATUS. — Valid.

DiAGNOSIS. - "Latentifistulidae having an internal framework in the form of a non-porous sphere with five hollows rays. Four rays usually radiating from the sphere at angles of $90^{\circ}$, the fifth perpendicular to them. The internal frame enclosed primarily in spongy shell. External form of the skeleton showing five subcylindrical arms radiating from a rounded central area." (Nazarov \& Ormiston 1983b: 374).

\section{Raciditor Sugiyama, 2000}

Raciditor Sugiyama, 2000: 227.

TYPE SPECIES. - Nazarovella gracilis De Wever \& Caridroit, 1984 (De Wever \& Caridroit 1984: 101, pl. 1, fig. 14-15, 17).

Age And location of type material. — Upper Permian, Tatsuno Formation, Hyogo Prefecture, southwest Japan.

TAXON CODE. - 199

STATUS. - Junior synonym of Quadricaulis Caridroit \& De Wever, 1986 (herein).

\section{REMARKS}

Sugiyama (2000) commented that the generic name $\mathrm{Naz}$ arovella was first used by Kozur \& Mostler (1979) for Triassic spherical radiolarians (spumellarian or entactinarian) possessing isometrically arranged spines with a quadrifurcated tip and proposed the replacement name Raciditor for Nazarovella De Wever \& Caridroit, 1984.

\section{Family Pseudolithelindae Kozur \& Mostler, 1989 sensu De Wever et al. (2001)}

Pseudolitheliidae Kozur \& Mostler, 1989: 185. — De Wever et al. 2001: 100 .

Grandetorturidae Sashida \& Tonishi, 1991: 90 (by De Wever et al. 2001: 100; see remarks in Nestell \& Nestell 2010).

\section{REMARKS}

De Wever et al. (2001) note that the central feature of this family is the spiraled growth of the test. Their emended definition includes features in common with other Latentifistularia, including a microsphere with ectopic spicule. We restrict the Pseudolithellidae to Octotormentum, and Grandetortura which both show the spiraled shell. Other genera that De Wever et al. (2001) included in the Pseudolithellidae, including Tetratormentum, and Tetragregnon, are now placed in the Tetratormentidae Nestell \& Nestell, 2010.

\section{Grandetortura Sashida \& Tonishi, 1991}

Grandetortura Sashida \& Tonishi, 1991: 90.

TYPE SPECIES. — Grandetortura nipponica Sashida \& Tonishi, 1991 (Sashida \& Tonishi 1991: 92, pl. 1, fig. 1-15, pl. 2, fig. 1-14).
Age and location of type Material. - Upper Permian, Kashiwara, Itsukaichi town, Tokyo Prefecture, central Japan.

TAXON CODE. -200 .

STATUS. - Valid.

DiAGNOSIS. - "Grandetorturiidae having subspherical or subelliptical outer shell with spherical or elliptical medullary shell without outer spines. Porous or pillared skeleton superimposed streptospirally around medullary shell creating a tube-like tunnel inside the skeleton.” (Sashida \& Tonishi 1991: 90).

Octatormentum Nazarov \& Ormiston, 1985

Octatormentum Nazarov \& Ormiston, 1985: 42.

TYPE SPECIES. - Octatormentum cornelli Nazarov \& Ormiston, 1985 (Nazarov \& Ormiston 1985: 42, pl. 5, fig. 14-16).

Age and location of type material. — Leonardian (Lower Permian), Bone Springs Limestone, West Texas, USA.

TAXON CODE. -201.

STATUS. - Valid.

SynOnYM. — Pseudolithelius Kozur \& Mostler, 1989.

DiAGNOSIS. - " "Tormentidae with three shells, innermost nonporous, outermost with bipyramidal outline, six major spines, four emerging at the comers of the equatorial plane, the other two at the apices of each pyramid. These external spines are continuations of the six internal rays. Outer shell spongy, but sometimes differentiated into a discrete cellular fabric." (Nazarov \& Ormiston 1985: 42).

\section{Pseudolithelius Kozur \& Mostler, 1989}

Pseudolithelius Kozur \& Mostler, 1989: 185.

TyPe SPECIES. - Pseudolithelius permicus Kozur \& Mostler, 1989 (Kozur \& Mostler 1989: 186, pl. 17, fig. 1, 4, pl. 18, fig. 1a-f).

Age AND LOCATION OF TYPE MATERIAL. - Upper Kungurian, Koselev Formation, right bank of the River Aj, Aloga Zovo village, Cis-Urals, Russia

TAXON CODE. - 202.

STATUS. - Junior synonym of Octatormentum Nazarov \& Ormiston, 1985 (by De Wever et al. 2001).

DiAgNOSIS. - "Mit den Familienmerkmalen. Schale außen subsphärisch, gerundet subpolyhedrisch bis gerundet bipyramidal. Die Windungshöhe der Schale nimmt von innen nach außen zunächst etwas zu, in der letzten Windung dagegen stark ab, oder sie bleibt durchgehend annähernd gleich hoch. Von den 6 dreikantigen Hauptstacheln zweigen Apophysen ab, welche die Hauptstacheln mit der Schale verbinden. Um die Stacheln herum treten dabei in der Schale sehr große Poren auf. In der äußeren niedrigen Windung sind die beiden Schalenwindungen zusätzlich durch stachelförmige Stützbalken miteinander verbunden.” (Kozur \& Mostler 1989: 185).

DiAGNOSIS (English translation by J. P. Caulet RadWorld database - modified by Jörg Maletz). - "With family characteristics. Shell with a sub-spherical, rounded sub-polyhedral to bi-pyramidal, outline. The coil height of the shell spirals develop increases the inner to the outer side; in the last turn, however, the spiral decreases rapidly, or remains constant. Branched apophyses develop from the 6 three-sided main spines, linking the spines to the shell wall. Very large pores are found around the spines. Secondary spine-like bars connect the outer two cortical shell spirals." 


\section{REMARKS}

This genus was synonymized with Octatormentum Nazarov \& Ormiston, 1985 because of the strong similarity in the coiling, the shell wall structure, and disposition of the spines and bars.

\section{Family Tetratormentidae Nestell \& Nestell, 2010}

\section{REMARKS}

This family was erected to include tetrahedral and bipyramidal forms that possess a microsphere and a 4-6 rayed spicule. The external shell is spongy or platy. This family houses forms that do not neatly fit into the triangular spongy Ruzencivespongidae, nor the spiraled Pseudolithellidae. Included within are Tetratormentum, Tetragregnon, Quadrilobata, and tentatively Mostlerispongus.

\section{Archaeopyramisa Cheng, 1986}

Archaeopyramisa Cheng, 1986: 185.

TYPE SPECIES. - Archaeopyramisa haeckeli Cheng, 1986 (Cheng 1986: 186, pl. 4, fig. 4, 5, 11, 13, 17-19, 22, pl. 5, fig. 1, 18, 19, 22).

AgE AND LOCATION OF TYPE MATERIAL. - Lower Carboniferous, Oklahoma and Arkansas, USA.

TAXON CODE. - 203.

STATUS. - Junior synonym of Tetragregnon Nazarov \& Ormiston, 1985 (by De Wever et al. 2001: 101, 102).

DiAGNOSIs. — "Test pyramidal, sub-tetrahedral, sub-spherical to spherical with four solid spines at tips. Cortical shell variably labyrinthine with hollow bars connected irregularly forming polygonal pores. Latticed medullary shell centrally positioned with polygonal pore frames, variable in shape connected to cortical shell by radially arranged hollow beams. Radial beams originating from four corners of medullary shell which is continuous with six edges of medullary shell and appearing to be continuous with solid spines of cortical shell. Meshwork of cortical shell decreasing in density towards central area and usually leaving a space between cortical and medullary shells or with only loosely labyrinthine meshwork." (Cheng 1986: 185).

\section{REMARKS}

De Wever et al. (2001) synonymize this genus with another tetrahedral form, Tetratormentum. Herein, we consider the shell construction closer to Tetragregnon, because of the spongiose nature of the shell throughout. The latticed medullary shell described by Cheng is not clearly illustrated in his SEM photos but appears to part of the inner meshwork of a Tetragregnon. we do not recognize the "labyrinthine" hollow bars as a diagnostic criterion as discussed under the family Latentifistuliade. The diagnosis of Archaeopyramisa contains all of the diagnostic characters of Tetragregnon Nazarov \& Ormiston, 1985, including the presence of a latticed medullary shell four rays, and the gross shape and labyrinthine meshwork covering the medullary shell. One difference is the stated variability of the shape of the medullary shell in Archaeopyramisa, but we do not consider this sufficient to warrant a new genus. Given its occurrence in the same age material, and the strong morphological similarity in other ways, we support the synonymy under Tetratormentum.

\section{Mostlerispongus Kozur, 1993}

\section{Mostlerispongus Kozur, 1993: 110.}

TYPE SPECIES. - Mostlerispongus sosioensis Kozur, 1993 (Kozur 1993: 110, pl. 2, fig. 5; by monotypy).

Age and location of type material. - Upper Permian, Dzhulfian, Western Sicily, Italy.

TAXON CODE. -204 .

STATUS. — Valid.

ORIGINAL DIAGNOSIS. - Spongy shell globular to slightly ellipsoidal, with 6 spongy, short round arms with the same diameter throughout their length. These arms are arranged in 3 axes, perpendicularly to each other. All arms end in a terminal, basally carinate spine of round cross section.

\section{REMARKS}

Nestell \& Nestell (2010) suggest that this taxon be placed in the family Tetratormentidae.

\section{Quadrilobata Wang, 1995}

Quadrilobata Wang, 1995: 144.

TYPe SPECIES. - Quadrilobata ephippiomorpha Wang, 1995 (Wang 1995: 144, pl.2, fig.16).

Age and location of type material. - Lower Permian, Gufeng Formation, Hushan area, Nanjing, Jiangsu Province, China.

TAXON CODE. -205 .

STATUS. - Valid.

DiAGNOSIS. 一 “壳体由 4 个粗壮的射肢组成, 外形似鞍. 射肢 始端增粗, 末端变细, 相互以 90 . 角由中央区伸出. 2 个相对的 射肢向下弯曲, 另外 2 个相对的射肢向上尧起. 壳外表面具海 绵状网孔.” (Wang 1995: 144)。

DiAGNOSIS (English translation). — "Skeleton is made of four stout limbs, shaped like a saddle. Beginning of limb thick, thinning towards the end. Limbs at $90^{\circ}$ angle to one another. Angle extends from the central area. Two opposed limbs bent downwards, another two opposed limbs directed with an upward tilt. Outer shell surface has a spongy mesh."

\section{REMARKS}

Wang (1995) originally assigned this genus to Ruzhencevispongidae. The radiolarians were extracted from chert and preservational differences make it difficult to compare it with other genera within this order, which are well preserved and extracted from limestone. This genus might be a less wellpreserved version of Brianellium Cheng, 1986, which shares a similar gross morphology. No spines are observed on the terminae of Quadrilobata but this might be a preservational issue, as spines are also absent from the terminae of Latentifistula in the same material. 
Tetracircinata Nazarov \& Ormiston, 1984 sensu Nazarov (1988)

Tetracircinata Nazarov \& Ormiston, 1984: 74. — Nazarov 1988: 66.

TYPE SPECIES. - Tetracircinata reconda Nazarov \& Ormiston, 1984 (Nazarov \& Ormiston 1984: 74; pl. 5, fig. 1-3, holotype never figured, paratype pl. 5, fig. 2).

Age and location of type material. - Artinskian, Lower Permian, Southern Urals, Russia.

TAXON CODE. - 206.

STATUS. - Junior synonym of Tetragregnon Ormiston \& Lane, 1976 (by De Wever et al. 2001).

DiAGNOSIS. - “Губчатые Heplentactiniidae, внутренний каркас которых преАставлен четырехлучевой спикулой. Ее кучи постепенно переходят в массивные иглы с неравномерным расположением апофизов их дальнейшее ветвление и соединение друг с Аругом образует несколько замкнутых или полузамкнутых внутренних оболочек”. (Nazarov \& Ormiston 1984: 74).

DiAGNOSIS (English translation by J. P. Caulet - RadWorld database). - "Internal structure represented by a spicule with only four rays. At a distance of 30-40 $\mu \mathrm{m}$ from the center, the rays from the spicule become more robust and develop in their proximal parts groups of irregularly developed apophyses, that merge to each other to form a somewhat closed, or half-closed, internal envelope. Sometimes an external coarsely spongy layer with small meshes. 4, sometimes 2-3, external conical spines, rarely rod-like with angular bases."

\section{REMARKS}

See Nestell \& Nestell (2010) for a discussion of this genus and its inclusion as a junior synonym under Tetragregnon, as proposed by De Wever et al. (2001)

\section{Tetragregnon Ormiston \& Lane, 1976}

Tetragregnon Ormiston \& Lane, 1976: 167.

Tetracircinata Nazarov \& Ormiston, 1984: 74.

Tetraspongoactinia Won, 1998: 257.

TYPE SPECIES. - Tetragregnon sycamorensis Ormiston \& Lane, 1976 (Ormiston \& Lane 1976: 167, pl. 2, fig. 6-8).

Age AND LOCATION of TYPE MATERial. - Mississippian (Lower Carboniferous), Sycamore Limestone, Arbuckle Mountains, Oklahoma, USA.

TAXON CODE. -207.

STATUS. - Valid.

DiAGNOSIS. - "A tetrahedral spicule of rod-like spines enclosed in a spongy tetrahedral network. The internal spicule continues externally as rod-like spines with fine secondary spines on them." (Ormiston \& Lane 1976: 167).

Tetraspongoactinia Won, 1998
TYPE SPECIES. - Tetraspongoactinia holdsworthi Won, 1998 (Won 1998: 257, pl. 4, fig. 10-12).

AgE AND LOCATION OF TYPE MATERIAL. — Tournaisian, Rheinische Schiefergebirge, Germany.

TAXON CODE. -208

STATUS. - Junior synonym of Tetragregnon (by Nestell \& Nestell 2010).

DiAGNOSIS. - "A very thin one-layered to thick spongy, subtetrahedral shell with one large to several small openings at each corner; apophyses arising from the four rays of the tetrahedron and apophysis branches connected with the meshwork of the shell." (Won 1998: 257).

\section{REMARKS}

Misspelled as Tetraspongentactinia in Won \& Seo (2010). We follow Nestell \& Nestell (2010) in synonymizing with Tetragregnon. Won's type material is from the Tournaisian of Germany, slightly older than the age for the Sycamore Limestone which is Visean, as reported by Schwartzapfel \& Holdsworth (1996).

\section{Tetratormentum Nazarov \& Ormiston, 1985}

Tetratormentum Nazarov \& Ormiston, 1985: 42.

TYPE SPECIES. - Tetratormentum narthecium Nazarov \& Ormiston, 1985 (Nazarov \& Ormiston 1985: 42, pl.5, fig. 8-9; holotype never figured, paratype pl. 5, fig. 8).

Age and location of type Material. - Gzhelian, Upper Carboniferous, Nikol village, Ural River, Southern Urals, Russia.

TAXON CODE. -209 .

STATUS. - Valid.

DiAgNosis. - "Mainly pyramidal Tormentidae with four-rayed internal framework enclosed in quite thick spongy or platy shell. External spines connected with rays of internal framework well developed in all species of the genus." (Nazarov \& Ormiston 1985: 42).

\section{Family RuZHENCEVISPONGIDAE Kozur, 1980}

Ruzhencevispongidae Kozur, 1980: 236.

Tormentidae Nazarov \& Ormiston, 1983b: 375.

\section{REMARKS}

Included in this family are triangular forms with an imperforate microsphere and 3 coplanar rays enveloped in a spongy pillow. There is a gap between the microsphere and the spongy pillow. Excluded from this family are the lobulate 3 and 4 rayed forms (Latentifistulidae), and pyramidal or bipyramidal forms (Tetratormentidae, Pseudolithellidae). 
TyPe SPECIES. - Latentidiota visenda Nazarov \& Ormiston, 1985 (Nazarov \& Ormiston 1985: 29, pl. 3, fig. 7).

AgE AND LOCATION OF TYPE MATERIAL. - Gzhelian (Upper Carboniferous), Don village, Ural River, Southern Urals, Russia.

TAXON CODE. -210

STATUS. — Valid.

DiAGNOSIS. - "Triangular or lobate-triangular Ruzhencevispongidae. Hollow rays of internal framework emerging at $120^{\circ}$ angles from sphere, crossing directly to terminal spines. External shell spongy, rarely lattice laminar. Marginal border distinct in some species, weakly expressed in others." (Nazarov \& Ormiston 1985: 29).

Nazarovispongus Kozur, 1980 sensu Kozur \& Mostler (1989)

Nazarovispongus Kozur, 1980: 237. — Kozur \& Mostler 1989: 205.

TYPe SPECIES. - Nazarovispongus pavlovi Kozur, 1980 (Kozur 1980: 238, pl. 1, fig. 6, pl. 2, fig. 1-2).

Age AND LOCATION OF TYPE MATERIAL. - Lower Sakmarian, CisUrals, Russia.

TAXON CODE. -211 .

STATUS. - Junior synonym of Ruzhencevispongus Kozur, 1980 (by Dumitrica 1984: 100).

DiAgNOSIS. - "Mit den Familienmerkmalen. Schale subtriangular bis triangular mit konvexen Rändern oder zugespitzten und abgerundeten Ecken. Markschale unperforiert, beknotet oder fein bestachelt, mit drei runden Stacheln, an deren Basis drei große Poren sitzen. In den drei Ecken der Schale geht von den drei Stacheln ein grobporiges schwammiges Gewebe aus." (Kozur 1980: 237).

DiagnOSIS (English translation by J. P. Caulet - RadWorld database). - "With the characteristics of the family. Shell sub-triangular to triangular with convex sides, and sharp or blunt corners. Medullary shell with no pores, its surface nodulous or spinose, with 3 spines of circular section, having each a large pore at its basis. At the three corners of the shell a coarsely spongious meshwork surrounds the base of the spines."

ReVISED Diagnosis. - "Umriß in der Aufsicht gerundet subtriangular mit konvexen Außenseiten. 3 breite, aber kurze tricarinate Stacheln in Dreiecksanordnung sind ausgebildet. Ober- und Unterseite schwach bis mäßig gewölbt. Schalenstruktur spongiös. Größter Teil des Gehäuses zwischen dem Innenskelett und der Außenwand mit spongiösen Gewebe gefüllt, nur die Umgebung der unperforierten Markschale ist frei. Das Innenskelett besteht aus einer subsphärischen, ungegitterten beknoteten Markschale, auf der in Dreiecksanordnung in einer Ebene 3 hohle Kegel aufgesetzt sind, die aus kegelförmig angeordneten, miteinander verschmolzenen Stäben aufgebaut sind und jeweils eine Pore aufweisen. Von den Spitzen dieser Kegel verläuft je ein nadelförmiger Stachel bis zu den 3 Außenstacheln. Vom mittleren und distalen Teil dieser Stacheln zweigen Apophysen ab, die mit dem spongiösen Gewebe verbunden sind." (Kozur \& Mostler 1989: 205).

English TRAnSLation (by J. P. Caulet RadWorld database modified by Jörg Maletz). - "Equatorial outline circular to sub-triangular with convex external sides. Three wide, short, three-sided spines in triangular order. Upper and lower sides slightly to strongly inflated. Shell structure spongy. Major part of the test between the inner skeleton and the external envelope occupied by a spongy tissue, with an empty space located only near the imperforate medullary shell. Inner structure composed of a sub-spherical, unlatticed, knobby medullary shell with three high cones on the same plane and in triangular distribution, that are formed by bars linked altogether to form a cone with a pore. Needle-shaped spines grow from the ends of the cones and connect to the 3 external spines. Middle and distal parts of these internal spines branching in apophyses connect to the spongy tissue."

\section{REMARKS}

Dumitrica (1984) considers this genus a junior synonym of Ruzhencevispongus Kozur, 1980 because of the strong overlap in definitions. Nestell \& Nestell (2010) keep it as a separate genus, restricted to the type species, which is more inflated than Ruzhencevispongus. Here we follow Dumitrica (1984).

\section{Patrickella Kozur \& Mostler, 1989}

Patrickella Kozur \& Mostler, 1989: 214.

TYPE SPECIES. - Ruzhencevispongus cataphractus Nazarov \& Ormiston, 1985 (Nazarov \& Ormiston 1985: 29, pl. 3, fig. 1-2; holotype never figured, paratype pl. 3, fig. 1).

Age and location of type material. - Lower Permian, Artinskian Stage, Aktastinian Substage, Southern Urals, Ural River, Don Village, Russia.

TAXON CODE. -212 .

STATUS. - Junior synonym of Ruzhencevispongus Kozur, 1980 (herein).

DiAGNOSIS. — "Mit den Familienmerkmalen. Äußere Schale rundlich grob gegittert, zentral feinporig gegittert oder dicht. Die 3 Strahlen des Innenskeletts sind nadelförmig und nur basal hohl. Die Markschale ist in eine zarte, triangulare spongiöse Schale eingebettet." (Kozur \& Mostler 1989: 214).

DiAGNOSIS (English translation by J. P. Caulet - RadWorld database - modified by Jörg Maletz). — "With the morphological characteristics of the family. Globular and coarsely lattice external shell, with a central part finely latticed or dense. Three rays of the internal framework needle-shaped and with a hollow basis. Medullary shell included inside a triangular delicately spongy shell."

\section{REMARKS}

De Wever et al. (2001: 103) misspell the name Patrickaella [sic] but do not synonymize. Nestell \& Nestell (2010: 52) discuss but retain the genus Patrickella, but herein we synonymize due to similarity in their diagnoses.

\section{Rectotormentum Nazarov \& Ormiston, 1985}

Rectotormentum Nazarov \& Ormiston, 1985: 41.

TYPE SPECIES. - Rectotormentum fornicatum Nazarov \& Ormiston, 1985 (Nazarov \& Ormiston 1985: 41, pl. 5, fig. 10-11; holotype never figured, paratype pl. 5, fig. 11).

Age and location of type material. - Artinskian (Lower Permian), Don village, Ural River, Southern Urals, Russia. 
TAXON CODE. -213.

STATUS. — Valid.

DIAGNOSIS. - " "Tormentidae with a spongy outer layer and varied structure of the internal framework. Among them are developed severa intercalated shells whose outlines duplicate the external outline. The shells are connected to one another by irregularly positioned beams and three, rarely more, rays arising from the internal framework. The structure of the internal framework is not adequately known. In one species it is represented by a non-porous sphere with rays emanating at angles of 120"; among others, it gives the impression of the presence of a three-rayed spicule. Terminal spines developed in some species, but they also may be absent" (Nazarov \& Ormiston 1985: 41).

\section{Ruzhencevispongus Kozur, 1980 sensu Kozur \& Mostler (1989)}

Ruzhencevispongus Kozur, 1980: 237. - Kozur \& Mostler 1989: 204 .

Nazarovispongus Kozur, 1980: 237. — Kozur \& Mostler 1989: 205.

Patrickella Kozur \& Mostler, 1989: 214 (n. syn.)

TYPE SPECIES. - Ruzhencevispongus uralicus Kozur, 1980 (Kozur 1980: 237, pl. 1, fig. 1-3).

AgE AND LOCATION OF TYPE MATERIAL. - Kungurian (Leonardian) and Sakmarian (Lower Permian), Cis-Urals, Russia.

TAXON CODE. -214

STATUS. - Valid.

REVISED DIAGNOSIS. - "Umriß triangular mit geraden bis leich konkaven Seiten. Stacheln an den Eckpunkten des Dreiecks gelegen, klein, z.T. fehlen sie ganz. Gehäuse randlich gerundet, Ober- und Unterseite schwach bis mäßig gewölbt. Schalenstruktur spongiös, wobei die äußerste Schicht feinporig ist, während nach innen das Gewebe grobzeilig wird. Dises spongiöse Gewebe füllt den größten Teil des Raumes zwischen dem Innenskelett und der Gehäuseoberfläche aus. Nur die unmittelbare Umgebung der unperforierten Markschale ist frei. Das Innenskelett besteht aus einer unperforierten Markschale, von der in Dreiecksanordnung 3 Fortsätze ausgehen, von denen das schwammige Gewebe abzweigt. Nur die Basis dieser Fortsätze ist hohl, im übrigen Teil sind es nadelförmige Stacheln. Weitere Stützbalken in der Umgebung der 3 Fortsätze können ebenfalls die Verbindung des schwammigen Gewebes des Außenskeletts mit der Markschale herstellen.” (Kozur \& Mostler 1989: 204).

DiAGNOSIs (English translation by J. P. Caulet - RadWorld database - modified by Jörg Maletz). - "Outline of the test triangular with straight or slightly concave sides. Spines located at the corners of the triangle, small, partly missing. Test edges rounded, upper and lower sides slightly to strongly inflated. Shell structure spongy, with an external layer finely porous, and a loose meshwork inside. This spongy meshwork occupies the major part of the inner cavity between the inner skeleton and the surface layer. Only the immediate surroundings of the non-porous medullary shell is free. The inner skeleton is constituted by an imperforate medullary shell producing three appendages in a triangular distribution, which branch off in the spongy tissue. Only the bases of these appendages are hollow and their other part is a spine. Additional bars near the three appendages can also link the spongy tissue of the external skeleton to the medullary shell."

\author{
Scharfenbergia Won, 1983 \\ sensu Kozur \& Mostler (1989)
}

Scharfenbergia Won, 1983: 158. — Kozur \& Mostler 1989: 220.

TYPE SPECIES. - Spongotripus concentricus Rüst, 1892 (Rüst 1892: 173, pl. 25, fig. 4).

AgE AND LOCATION OF TYPE MATERIAL. - Lower Carboniferous, Rheinischen Schiefergebirge, Germany.

TAXON CODE. -215 .

STATUS. - Homonym; replacement name is Wonia Özdikmen, 2009.

DiAGNOSIS. — "Das Skelett ist im Habitus triangular bis dreiarmig und besteht aus spongiösem Geflecht. Dieses kann sowohl individuell als auch interspezifisch unterschiedlich stark entwickelt sein. Durch Verdickung ist es bei einigen Arten säulenartig ausgebildet. Im Innern des Skeletts liegt eine sphäroidale Zentralschale. 3 von ihr ausgehende axiale Stäbe sind mit dem umgebenden Gewebe verbunden und können sich in distaler Richtung verdicken. Sie sind an den Ecken des Skeletts bzw. an den Enden der Arme als kurze Stacheln sichtbar." (Won 1983: 158).

Diagnosis (English translation by J. P. Caulet RadWorld - database). - "Triangular to three-armed spongy test. Various shapes between triangular and three-arms can be observed at individual, or intraspecific, level. Some species can be column-shaped through thickening of the test. Spherical central shell inside the test. Three axial rods link the internal shell to the surrounding framework and can thicken in distal direction. They are visible as short spines at the corners of the test, i.e. the ends of the arms."

\section{REMARKS}

There is considerable taxonomic overlap between the original diagnoses proposed for this genus by Won (1983) and and Latentifistula Nazarov \& Ormiston, 1983, but since their original publication, revisions to both genera have alleviated the problem. Subsequent usage of Scharfenbergia, as proposed by Kozur \& Mostler (1989) and discussed in Nestell \& Nestell (2010), restricts Scharfenbergia to the triangular forms similar to the Mississippian age holotype. Meanwhile, Latentifistula includes triradiate or trilobate species that Won (1983) had assigned to Scharfenbergia, including Paronaella impella Ormiston \& Lane, 1976. Scharfenbergia is the junior homonym to the arthropod Scharfenbergia Oudemans, 1936. As Scharfenbergia is preoccupied the replacement name Wonia was proposed by Özdikmen (2009).

\section{Tormentum Nazarov \& Ormiston, 1983}

\section{Tormentum Nazarov \& Ormiston, 1983b: 376.}

TYPE SPECIES. - Tormentum protei Nazarov \& Ormiston, 1983 (Nazarov \& Ormiston 1983b: 376, pl. 1, fig. 3; holotype never figured, paratype, pl. 1, fig. 3).

Age AND location of tyPE MATERIAL. - Gzhelian, Upper Carboniferous, Nikol village, Ural River, Southern Urals, Russia.

TAXON CODE. -216 .

STATUS. — Valid. 
DiAGNOSIS. - "Subtriangular, oval, lensoid Tormentidae with a threerayed internal frame, which is partially or completely enclosed in a thick, sometimes weakly differentiated, spongy layer. External terminal spines connected with rays of the internal frame are developed in one species and absent in others." (Nazarov \& Ormiston 1983b: 376).

\section{Wonia Özdikmen, 2009}

Wonia Özdikmen, 2009: 247.

TYPE SPECIES. - Spongotripus concentricus Rüst, 1892 (Rüst 1892: 173, pl. 25, fig. 4).

TAXON CODE. -217 .

STATUS. — Valid.

REMARKS

Replacement name proposed for homonym Scharfenbergia Won, 1983.

Order ?NASSELLARIA Ehrenberg, 1876

\author{
Family ARCHOCYRTIIDAE Kozur \& Mostler, 1981 \\ sensu Cheng (1986)
}

\section{REMARKS}

There is some disagreement, even amongst the authorship of this chapter, about placement of this family. Cheng (1986) and Dumitrica (in De Wever et al. 2001) argue for placement in Nassellaria, citing similarities in the seven-rayed spicule with the early cyrtoid Nassellaria in the Triassic, and external similarity with some Triassic forms. Riedel (1967) and Holdsworth (1973) maintain their place as pylomate entactinarians, citing a 65 million year gap between the last appearance of the Archocyrtidae and the Triassic Nassellaria. They also cite the instability of the position of the rays, which can flip from apical to basal position in the Archocyrtidae. Ray position is stable in the Triassic nassellarians.

\section{Allocyrtium Afanasieva, 1986}

Allocyrtium Afanasieva, 1986: 31

TYPE SPECIES. - Archocyrtium castuligerum Deflandre, 1972 (Deflandre 1972a, pl. 4, fig. 6, nomen nudum); Deflandre 1972b: 15.

AgE AND locATION OF TYPE MATERIAL. - Visean (Lower Carboniferous), Cabrières, Hérault, Montagne Noire, France.

TAXON CODE. -218 .

STATUS. - Junior synonym of Archocyrtium Deflandre, 1972b (herein).

DIAGNOSIS. - “Раковина уАлиненно-конической формы, стенка центральной субсферической части раковины - цефалиса пористая. Внутренний каркас представлен четырехлучевой спикулой, расположенной в центре цефалиса. Раковина несет четыре основные трехгранные иглы, три из которых окружают пимом, а одна, аборальная занимает осевое положение. Три основные иглы, окаймАяющие пимомное отверстие, соединены широкой непористой пластинкой в виде субконического перистома." (Afanasieva 1986: 31)
Diagnosis (English translation by J. P. Caulet - RadWorld database). - "Shell elongated-conical, central part of the subspherical part (cephalis) porous. Intetrnal structure represented by a four-rays spicule, at the centre of the cephalis. Four main spines, three-sided, three of them around the pylome, the other one, aboral, in axial location. The three main spines at the border of the pylome are reunited around the aperture by a wide, imperforate plate, shaped as a sub-conical peristome."

\section{REMARKS}

The distinction of having an imperforate peristome, made by Afanasieva (1986) and used as a criterion to introduce a new genus, is herein regarded as a species rather than genus level difference.

\section{Archocyrtium Deflandre, 1972 sensu Holdsworth (1973)}

Archocyrtium Deflandre, 1972b: 15; 1960: 216 (nomen nudum). Holdsworth 1973: 122.

Allocyrtium Afanasieva, 1986: 31 (n. syn.)

TYPE SPECIES. - Archocyrtium riedeli Deflandre, 1960 (Deflandre 1960: 216, pl. 1, fig. 17, nomen nudum); Deflandre 1972a: 3537, pl. 4, fig. 4-5; 1972 b: 15 .

Age AND location of type MATERial. - Visean (Lower Carboniferous), Cabrières, Hérault, Montagne Noire, France.

TAXON CODE. -219 .

STATUS. — Valid.

Diagnosis. - “Céphalis sphérique perforé surmonté d'une corne apicale ou subapicale costulée, avec un podome de trois cornes autour d'un pylome dont le bord peut se prolonger entre les cornes, constituant ainsi un pseudothorax jamais perforé. Système trabéculaire interne comportant quatre actines, parfois conservé partiellement, souvent disparu" (Deflandre 1972b: 15).

REVISED DIAGNOSIS. - "A single, perforate lattice shell with only four main spines, three of which are positioned symmetrically in the pylome margin, the fourth constituting an apical spine positioned at the opposite pole from the pylome centre. Internal spicules are completely absent in some species but well developed in others. A pylome net is invariably absent." (Holdsworth 1973: 122).

\section{Cerarchocyrtium Deflandre, 1973}

Cerarchocyrtium Deflandre, 1973d: 151.

TyPE SPECIES. - Cerarchocyrtium ambiguum Deflandre, 1973d (Deflandre 1973d: 151, pl. 1, fig. 9, pl. 4, fig. 1).

AgE AND LOCATION OF TYPE MATERIAL. - Visean (Lower Carboniferous), Cabrières, Hérault, Montagne Noire, France.

TAXON CODE. -220.

STATUS. — Valid.

DiagnOSIs. - "Céphalis sphérique pourvu de deux cornes et d'un podome à 3 pieds avec un pseudo-thorax plus ou moins développé. Système trabéculaire à 5 trabécules." (Deflandre 1973d: 151). 
Diagnosis (English translation by J. P. Caulet - RadWorld database). - "Spherical cephalis bearing two horns and a podome with three feet and a more or less well-developed pseudo-thorax. Internal spicule with five spines."

\section{Ceratoclathrulum Deflandre, 1960 (nomen nudum)}

Ceratoclathrulum Deflandre, 1960: 216 (nomen nudum).

TyPe SPECIES. - Ceratoclathrulum ambiguum Deflandre, 1960 (Deflandre 1960: 216, pl. 1, fig. 8).

TAXON CODE. -221 .

STATUS. - Nomen nudum.

DiAGNOSIS. - undescribed.

\section{Cyrtisphaeractenium Deflandre, 1972}

Cyrtisphaeractenium Deflandre, 1972b: 14; 1960: 216 (nomen nudum).

TYPE SPECIES. - Cyrtisphaeractenium mendax Deflandre, 1960 (Deflandre 1960: 216, pl. 1, fig. 19, nomen nudum); Deflandre 1972a: 3535, pl. 1, fig. 5-11, pl. 2, fig. 4-5, pl. 3, fig. 1-6; 1972b: 15 .

Age AND location of TYPE MATERIAL. - Visean (Lower Carboniferous), Cabrières, Hérault, Montagne Noire, France.

TAXON CODE. -222

STATUS. - Valid.

DiAGNOSIS. - "Céphalis sphérique perforé avec des pores arrondis, largement espacés et peu nombreux, muni de quatre cornes costulées dont l'une est toujours courte et conique et deux autres grandes et non apicales. Ouverture large à bord portant une collerette épaissie, de laquelle partent de longues pointes rapprochées en dents de peigne, avec un podome formé de trois longues cornes tricostulées, droites ou un peu courbées, entre lesquelles subsistent des vestiges souvent très réduits de l'appareil pectiné. Système trabéculaire interne connu seulement par quelques vestiges en tigelles grêles, issues de la base des cornes et franchement dirigées vers le centre.» (Deflandre 1972b: 14).

DiAGNOSIS (English translation by Taniel Danelian). - Cephalis spherical, perforated by rounded pores that are not numerous and well-spaced, bearing four costate horns one of which is always short and conical, the two others are large and not apical. The opening is large and bears a thick collar, from which long spikes extend, they are brought together in the form of brush, with a podome that is formed by three long tri-bladed horns, which are straight or slightly curved, through which exist the remains of a pectinate (parallel-ridged) apparatus. The internal spicular (trabecular) system is known only from some remains with slender stalks extending from the base of the horns and truly directed towards the center.

ABRIDGED DESCRIPTION (translated from Deflandre [1972b] by J. P. Caulet). — See also Holdsworth (1973).

\section{Cyrtisphaeronemium Deflandre, 1972}

Cyrtisphaeronemium Deflandre, 1972b: 14; 1960: 216 (nomen nudum).

TYPE SPECIES. - Cyrtisphaeronemium prudentigerum Deflandre, 1960 (Deflandre 1960: 216, pl. 1, fig. 18, nomen nudum); Deflandre 1972a: 3535, pl. 1, fig. 1.
Age AND location of type MATERIAL. - Visean (Lower Carboniferous), Cabrières, Hérault, Montagne Noire, France.

TAXON CODE. -223.

STATUS. - Valid.

DiAGNOSIS. - "Céphalis sphérique perforé à pores circulaires peu rapprochés, muni de quatre cornes tricostulées dont l'une, non exactement apicale, est souvent plus développée. Ouverture large, à bord non épaissi, avec un podome constitué de trois cornes tricostulées, longues et plus ou moins courbées, entre la base desquelles s'intercalent, portées par une mince paroi, trois paires de grandes épines peu épaisses, non costulées. Système trabéculaire interne avec un bâtonnet médian des extrémités duquel partent trois et quatre trabécules fines rejoignant la base des sept apophyses" (Deflandre 1972b: 14).

DiAgNosis (English translation by Taniel Danelian). — "Cephalis spherical, perforated by circular pores that are not closely spaced to one another, bearing four costate horns one of which, not exactly apical, is often more developed. Opening large, with a thin border and with a podome that is formed by three long tri-bladed horns, which are long and more or less curved, and at the base of which is intercalated, and held by a thin wall, three pairs of large thin spines, which are not bladed. The internal spicular (trabecular) system bears a median bar from the extremities of which extend three and four thin spicules that join at the base seven apophyses."

\section{Deflandrellium Cheng, 1986}

Deflandrellium Cheng, 1986: 134.

TYPE SPECIES. - Deflandrellium georgesi Cheng, 1986 (Cheng 1986: 134, pl. 7, fig. 7, 13).

Age And location of type material. - Upper Famennian (Upper Devonian), Woodford Formation, Ouachita Mountains, Oklahoma, USA.

TAXON CODE. -224 .

STATUS. - Valid.

DiAGNOSIS. - " "Test as with family but possessing five asymmetrically arranged spines on shell surface, and one subapical horn and four feet. Cephalis spherical, perforate having sparsely to densely distributed pores with pore cones. Pylome large, circular with four feet surrounding of which one foot is always slightly higher in position. The narrow pylome is skirt-like, imperforate lacking a marginal fringe." (Cheng 1986: 134).

\section{Foremaniella Deflandre, 1972}

Foremaniella Deflandre, 1972b: 14

TYPE SPECIES. - Cyrtentactinia cibdelosphaera Foreman, 1963 (Foreman 1963: 285, pl. 8, fig. 3, pl. 9, fig. 4).

Age AND location of TyPe MATERIAL. - Upper Devonian, Huron member, Ohio Shale, USA.

TAXON CODE. -225 .

STATUS. - Valid.

Diagnosis. - "Coque sphérique perforée, munie d'un système trabéculaire à bâtonnet médian et sept (ou six ?) actines rejoign- 
ant sept (ou six ?) cornes dont trois (ou deux ?), plus développées, sont réunies par un bourrelet circulaire entourant une aire amincie perforée" (Deflandre 1972b: 14).

DiAGNOSIs (English translation by Taniel Danelian). — "Spherical perforated test, bearing a trabecular system formed of a median rod and seven (or six?) spines/spicules that join seven (or six?) horns, three (or two?) of which are more developed and joined by a circular rim that surrounds a thin perforated area."

\section{Mostlerium Cheng, 1986}

Mostlerium Cheng, 1986: 136.

Type SPECIES. - Mostlerium unicum Cheng, 1986 (Cheng 1986: 136, pl. 4, fig. 7, 8, 20, 23)

AgE AND LOCATION OF TYPE MATERIAL. - Lower Carboniferous, Oklahoma and Arkansas, USA.

TAXON CODE. -226.

STATUS. — Junior synonym of Pararchocyrtium Deflandre, 1972 (herein).

DiAGNOSIS. - " "Test as with family [Archocyrtidae] but possessing seven spines on the shell surface; three spines located on the upper hemisphere, of which one slightly lower in position and much shorter four other spines located on the lower hemisphere surrounding the pylome margin. Cephalis subspherical, perforate having large, circular pylome. Pylome margin having expanded skirt; narrow and imperforate." (Cheng 1986: 136).

\section{REMARKS}

Noble et al. (2008: 47) note the instability of the position of spines (either as feet or lateral spines) in Pararchocyrtium, and question the validity of using the number of feet as a criterion for genus level distinction in several of the archocyrtid taxa. We synonymize herein.

\section{Pararchocyrtium Deflandre, 1972}

Pararchocyrtium Deflandre, 1972b: 15; 1972a: 3537 (nomen nudum).

Mostlerium Cheng, 1986: 136 (n. syn.)

Robotium Cheng, 1986: 137 (n. syn.)

TyPe SPECIES. - Pararchocyrtium mirabile Deflandre, 1972 (Deflandre 1972a: 3537, pl. 4, fig. 1-3); Deflandre 1972b: 15.

AgE AND LOCATION OF TYPE MATERIAL. - Visean (Lower Carboniferous), Cabrières, Hérault, Montagne Noire, France.

TAXON CODE. -227

STATUS. — Valid.

DiAgNOSIs. - “Céphalis sphérique perforé portant quatre cornes costulées dont une toujours courte. Podome formé par trois cornes divergentes entourant le pylome. Système trabéculaire interne comportant sept actines. Ce genre diffère des deux précédents par l'absence de toute structure entre les cornes du podome." (Deflandre 1972b: 15)

DiAgNOSIS (English translation by J. P. Caulet - RadWorld database). - "Cephalis perforated spherical bearing four costate/folded? horns, one of which is always short. Podome is formed by three diverging horns surrounding the pylome. An internal trabecular system bears seven spines. This genus differs from the two previous ones by the absence of any structure between the horns of the podome."

\section{Robotium Cheng, 1986}

Robotium Cheng, 1986: 137.

TyPE SPECIES. - Robotium validum Cheng, 1986 (Cheng 1986: 139, pl. 3, fig. 3, 10, 11, 17, 21).

AGE AND LOCATION OF TYPE MATERIAL. - Lower Carboniferous, Oklahoma and Arkansas, USA.

TAXON CODE. -228

STATUS. - Junior synonym of Pararchocyrtium Deflandre, 1972 (herein).

DiAGNOSIS. - "Test as with family [Archocyrtidae] but possessing six asymmetrically disposed spines on the shell surface with two subapical horns and four feet." (Cheng 1986: 137).

REMARKS

See remarks under Mostlerium.

Family PopOFsKYellidae Kozur \& Mostler, 1981 emend Cheng (1986)

\section{Cyrtentactinia Foreman, 1963}

Cyrtentactinia Foreman, 1963: 284

TYPE SPECIES. - Cyrtentactinia primotica Foreman, 1963 (Foreman 1963: 285, pl. 8, fig. 2a-c, pl. 9, fig. 3a-b).

Age and location of TyPe Material. - Upper Devonian, Huron member, Ohio Shale, USA.

TAXON CODE. -229 .

STATUS. - Valid

DiAGNOSIS. - "Relatively large spherical or subspherical cephalis, enclosing a spicule with six to perhaps eight (commonly seven) rays arising from the ends of an oblique median bar. Thorax, perforate or imperforate, with or without marginal teeth, not separated from the cephalis by regular collar pores. The rays of the internal spicule continue beyond the wall of the cephalis, and in and beyond the wall of the cephalis, and in and beyond the thoracic wall, as external spines" (Foreman 1963: 284).

REVISED DiAGNOSIS. — "A single, perforate, pylomate lattice shell with internal spicular system incorporating six or seven rays. Externally, more than four main spines, usually seven and only rarely five, two to four of which are incorporated in the pylome margin. A pylome net is sometimes present and in some species, and in some individuals of other species, it is considered that spicules are secondary lost." (Holdsworth 1973: 122).

\section{Kantollum Cheng, 1986}

Kantollum Cheng, 1986: 163. 
TYPE SPECIES. - Kantollum pittsburgense Cheng, 1986 (Cheng 1986: 164, pl. 2, fig. 4, 8, 22).

AgE AND LOCATION OF TYPE MATERIAL. - Famennian to lower Kinderhookian (Upper Devonian to Lower Carboniferous), Woodford Formation, Ouachita Mountains, Oklahoma, USA.

TAXON CODE. -230 .

STATUS. - Valid.

DiAGNOSIS. - " "Test as with subfamily, conical, strongly or weakly lobulate. Four or more lobes with strictures at joints. Single layer of irregularly arranged pore frames; microgranular layer usually covering the spherical to subspherical cephalis. Sturdy apical and/or subapica horns and spines confined to the cephalic wall." (Cheng 1986: 142).

\section{Popofskyellum Deflandre, 1964 sensu Holdsworth (1966)}

Popofskyellum Deflandre, 1964: 3058; 1960 (nomen nudum). Holdsworth 1966: 326.

TyPe SPECIES. - Popofskyellum pulchrum Deflandre, 1960 (Deflandre 1960: pl. 1, fig. 26, nomen nudum); Deflandre 1964: 3055, fig. 1-2, 5-6.

AgE AND LOCATION OF TYPE MATERIAL. - Visean (Lower Carboniferous), Cabrières, Hérault, Montagne Noire, France.

TAXON CODE. -231 .

STATUS. - Valid.

DiAgNOSIS. - "Coque perforée campanuliforme ou conique, avec deux côtes ou baguettes latérales opposées, saillant généralement à la base; podome à deux branches; céphalis à cornes simples; présence fréquente d'une courte corne conique tricostulée (fig. 5, 6 et 10); système trabéculaire basal asymétrique mal connu (fig. 8 et 9)." (Deflandre 1964: 3058)

DiAGNOSIS (English translation J. P. Caulet - RadWorld database). "Bell-shaped or conical shell perforate with two opposite ribs or lateral rods, usually protruding at the base; podome with two branches; cephalis with simple horns; common occurrence of a short three-sided horn (figs. 5, 6 and 10); internal spicule not well known (figs. 8, 9).'

REVISED DIAGNOSIS. - Shell perforated, bell-shaped or conical, with two opposed lateral ribs or rods, usually projecting at the base. Podome with two branches. Cephalis with unbranched spines, frequently with a short, conical, tricostate spine. Poorly known, asymmetrical trabecular system basally. (Holdsworth 1966: 326).

Totollum Schwartzapfel \& Holdsworth, 1996

Totollum Schwartzapfel \& Holdsworth, 1996: 142.

TYPE SPECIES. - Totollum blomei Schwartzapfel \& Holdsworth, 1996 (Schwartzapfel \& Holdsworth 1996: 146, pl. 10, fig. 1, 2, 6, $7,12,13,16,17)$.

AgE AND LOCATION OF TYPE MATERIAL. - Upper Famennian (Upper Devonian), Woodford Formation, Criner Hills and southern Arbuckle Mountains, Oklahoma, USA.

TAXON CODE. -232 .

STATUS. — Valid.
Diagnosis. - "Test two-chambered, three-chambered, or multichambered, with or without strictures at joints, conical in shape, non-lobulate to distinctly lobulate in outline. First chamber small, hemispherical with two subapical horns. Horns thorn-like; solid, circular in axial section. Two diametrically opposed lateral rods originating close to base of first chamber, incorporated in the shell wall, and projecting either beyond the very base of the shell or halfway around the shell to form a wing-like structure. Test with single layer of pore frames with circular, elliptical or irregular, worm-like pores; pores usually densely and evenly distributed on the wall surface of the distal chambers. First chamber skeletal elements, extremely delicate, usually not preserved; confined to the interior of the first chamber only. Test with very weakly developed partition(s)." (Schwartzapfel \& Holdsworth 1996: 142).

\section{Tuscaritellum Deflandre, 1972}

Tuscaritellum Deflandre, 1972b: 16; 1963: 3982 (nomen nudum).

TyPE SPECIES. - Tuscaritellum imitatum Deflandre, 1963 (Deflandre 1963: 3982 [nomen nudum]); Deflandre 1972a: 3537, pl. 1, fig. 1; 1972b: 16 .

Age AND LOCATION OF TYPE MATERIAL. - Visean (Carboniferous), Cabrières, Montagne Noire, France.

TAXON CODE. - 233.

STATUS. - Valid.

DiAGNOSIS. - "Coque perforée cylindro-conique ou campanulée, s'atténuant vers l'apex qui est arrondi et forme un cephalis mal délimité, indiqué seulement par un très faible rétrécissement de la paroi, laquelle est dépourvue de toute autre marque. Céphalis muni de quatre (ou trois ?) petites cornes ou épines, simples. Coque portant, vers la partie médiane, deux petites apophyses ou cornes divergentes souvent inégalement développées; pylome ouvert, sans trace de podome. Système trabéculaire interne absent ou trop indistinct pour être décrit."(Deflandre 1972b: 16).

DiagnOSis (English translation by Paula Noble). — "Perforated cylindrical-conical or bell-shaped shell, decreasing towards the rounded apex with a poorly delimited cephalis, indicated only by a very slight recession of the wall, which is devoid of any other mark. Cephalis with four (or three?) small simple horns. Shell bears towards the middle two small horns or divergent processes often unevenly developed; pylome open, without a trace of a podome. Internal trabecular system is absent or too indistinct to be described."

Order SPUMELLARIA Ehrenberg, 1876

Family ANTYGOPORIDAE Maletz \& Bruton, 2007

Antygopora Maletz \& Bruton, 2005

Antygopora Maletz \& Bruton, 2005: 713.

TyPe SPECIES. - Antygopora ordovicica Maletz \& Bruton, 2005 (Maletz \& Bruton 2005: 715, fig. 2a-d, 3, 4, 5b, 6b).

Age AND Location of TYPE MATERIAL. - Uppermost Lower Ordovician, Spitsbergen (Svalbard).

TAXON CODE. -234 . 
STATUS. — Valid.

DIAGNOSIS. - "Spherical radiolarians with two cortical tests, formed by a typical thin layer pierced by round pores with elevated rims and ornamented on the surface with distinct connecting ridges forming a honeycomb pattern; internal spicule and spines apparently lacking." (Maletz \& Bruton 2005: 713).

Beothuka Aitchison, Flood \& Malpas, 1998

Beothuka Aitchison, Flood \& Malpas, 1998: 417.

Labyrinthia Maletz \& Bruton, 2007: 281.

Type SPECIES. - Beothuka terranova Aitchison, Flood \& Malpas, 1998 (Aitchison et al. 1998: 417, fig. 1a-o).

AgE AND LOCATION OF TYPE MATERIAL. - Lower Tremadocian (Lower Ordovician), Little Port Complex, western Newfoundland, Canada. Subsequently the red chert fauna of the Little Port complex has been reviewed by Won \& Iams (2013) and age assignment has been revised to the lower Arenig (middle Floian) correlating to the P. fruticosus graptolite Zone and O. evae conodont Zone of the Cow Head Group.

TAXON CODE. -235 .

STATUS. - Valid.

DiAGNOSIS. - "Ellipsoidal radiolarian with thick latticed to coarsely porous cortical shell. Robust bi-polar rodded spines tapering to a point." (Aitchison et al. 1998: 417).

\section{REMARKS}

Won \& Iams (2011) place Beothuka in the Antygoporidae of Maletz \& Bruton (2007) at the same time emending the diagnosis of this family.

\section{Labyrinthia Maletz \& Bruton, 2007}

Labyrinthia Maletz \& Bruton, 2007: 281.

TYPE SPECIES. - Labyrinthia inexpectata Maletz \& Bruton, 2007 (Maletz \& Bruton 2007: 281, fig. 27A-O).

AGE AND LOCATION OF TYPE MATERIAL. - Isograptus lunatus graptolite zone, Chewtonian-Castlemainian (Lower Ordovician), Valhallfonna Formation, Spitsbergen.

TAXON CODE. - 236 .

Status. - Junior synonym of Beothuka Won \& Iams, 2011. Won \& Iams (2011).

DiAGNOSIS. - "Labyrinthine spherical radiolarian with an indistinct microsphere and a variable number of external spines; labyrinthine mesh made of thin, anastomosing bandages."(Maletz \& Bruton 2007: 281).

\section{Parabeothuka Won \& Iams, 2015}

Parabeothuka Won \& Iams, 2015: 27.

TyPe SPECIES. - Parabeothuka transformis Won \& Iams, 2015 (Won \& Iams 2015: 27, pl. 10, fig. 5).

AgE AND LOCATION OF TYPE MATERIAL. - Upper Floian (Lower/ middle Arenig), Cow Head Group, Western Newfoundland, Canada.
TAXON CODE. -237.

STATUS. — Valid.

DiAgNOSIS. - "Spherical skeleton with three or four concentric and/or subconcentric shells formed by bandages; outer shell is spherical and two-dimensionally latticed by bandages with traces of labyrinthine meshwork structure. Proloculus with thin bandages or bars." (Won \& Iams 2015: 27).

\section{Family COPICYNTRIDAE Kozur \& Mostler, 1989}

Copicyntrinae Kozur \& Mostler, 1989: 215 (nom. transl.)

EMENDED DIAGNOSIS. - Spherical, ellipsoidal, to discoidal shell consisting of six to 11 spongy layers that show a planispiral arrangement in cross section. Layers may not be strongly distinguished. Spines occur in most taxa and vary from massive three-bladed spines to delicate needle-like spines. In some cases spines may be distributed in a polar arrangement (herein).

\section{REMARKS}

Nazarov \& Ormiston originally placed the genera contained herein within the Entactinaria, however no inner entactinarian spicule has been observed, even after sectioning (Noble $\&$ Jin 2010). Kozur \& Mostler (1989) erected the subfamily Copicyntrinae, which they placed in the spumellarian family Oertlispongidae. De Wever et al. (2001) use a narrower definition of the Oertlispongidae that is restricted only to the Mesozoic forms. Herein, we raise the rank of the Copicyntrinae to the family level, and emend the description to include spherical, ovate, and discoidal forms in order to accommodate several concentrically spongy upper Paleozoic genera.

\section{Bipylospongia Noble, 1994}

Bipylospongia Noble, 1994: 37.

TYPe SPECIES. - Bipylospongia rudosa Noble, 1994 (Noble 1994: 37, pl. 7, fig. 6-9).

Age AND LOCATION Of TYPE MATERial. - Silurian zones 1 and 2 (upper Wenlock-Ludlow?), Marathon uplift, west Texas, USA.

TAXON CODE. -238.

STATUS. - Valid.

DIAGNOSIS. — "Test ovate consisting of a spongy cortical shell with a hollow internal cavity and no medullary shell. Two pylomes occur; one at each pole which are often unequal in size. Pylomes are surrounded by five to eight spines or flanges of varying size. Cortical surface may or may not be covered with spongy nodes." (Noble 1994: 37).

\section{Copicyntra Nazarov \& Ormiston, 1985}

Copicyntra Nazarov \& Ormiston, 1985: 24.

TYPE SPECIES. - Copicyntra acilaxa Nazarov in Isakova \& Nazarov, 1986 (Isakova \& Nazarov 1986: 70, pl. 18, fig. 2).

AgE AND LOCATION OF TYPE MATERIAL. - Upper Carboniferous (Gzhelian), Southern Urals, Russia. 
TAXON CODE. - 239

STATUS. — Valid.

DiAGNOSIS. - "Astroentactiniidae with a spongy outer layer and porous inner sphere. Among them are developed 8-13, rarely more, thin concentric shells, which are nested. These shells probably represent differentiated spongy layers. All spheres are crossed by radial crossbeams joining with the bases of outer spines of varied form." (Nazarov \& Ormiston 1985: 24).

\section{Copicyntroides Nazarov \& Ormiston, 1985}

Copicyntroides Nazarov \& Ormiston, 1985: 28.

TYPE SPECIES. - Copicyntroides asteriformis Nazarov \& Ormiston, 1985: 28, pl. 2, fig. 12-13.

Age And location of type Material. — Upper Permian (Guadalupian), Lamar Limestone of Bell Canyon Formation, West Texas, USA.

TAXON CODE. -240 .

STATUS. - Valid.

DiAGNOSIS. - "Shell inflated, discoidal, consisting of finely cellular spongy outer layer and nine or ten concentric inner shells with a central spherical shell. Periphery with six to nine three-bladed spines with a gap in their radial arrangement, which marks a plane of bilateral symmetry." (Nazarov \& Ormiston 1985: 28).

Copiellintra Nazarov \& Ormiston, 1985

Copiellintra Nazarov \& Ormiston, 1985: 25.

Ellipsocopicyntra Kozur \& Mostler, 1989: 218.

TYPe SPECIES. - Copiellintra diploacantha Nazarov \& Ormiston, 1985 (Nazarov \& Ormiston 1985: 26; holotype never figured, paratype pl. 2, fig. 5).

Age and location of TyPe Material. - Lower Permian (Sakmarian), Kandurov Suite, Southern Urals, Russia.

TAXON CODE. -241 .

STATUS. - Valid.

DiAGNOSIs. - As with family, "Ellipsoidal Astroentactiniinae with spongy outer layer and porous inner sphere. Between these more than 10 ellipsoidal, thin shells developed, nested in each other. Radial crossbeams crossing all shells, sometimes continuing to external spines." (Nazarov \& Ormiston 1985: 25).

\section{REMARKS}

This genus, originally placed within the Astroentactiniidae by Nazarov \& Ormiston (1985), lacks entactinarian internal structures. See Noble \& Jin (2010) for a discussion of the history of the family-level assignment of this genus.

\section{Devoniglansus Wakamatsu, Sugiyama \& Furutani, 1990}

Devoniglansus Wakamatsu, Sugiyama \& Furutani, 1990: 171.

TyPe SPECIES. - Devoniglansus unicus Wakamatsu, Sugiyama \& Furutani, 1990 (Wakamatsu et al. 1990: 172, pl. 4. fig. 1-4).
Age and location of type Material. - Upper Silurian - Middle Devonian interval, Kurosegawa tectonic zone, southwest Japan.

TAXON CODE. -242 .

STATUS. — Valid.

DiAgnosis. - "Paleozoic spumellaria possessing ellipsoidal to acorn-like shell with multishelled structure consisting of a number of thin layers, one apical spine, and a basal hole surrounded by basal spines." (Wakamatsu et al. 1990: 171).

\section{Ellipsocopicyntra Kozur \& Mostler, 1989}

Ellipsocopicyntra Kozur \& Mostler, 1989: 218.

TYPE SPECIES. - Ellipsocopicyntra oviformis Kozur \& Mostler, 1989 (Kozur \& Mostler 1989: 218, pl. 15, fig. 1).

Age and location of type material. - Kungurian, Koshelev Formation, Cis-Urals, Russia.

TAXON CODE. -243 .

STATUS. - Junior synonym of Copiellintra (by Noble \& Jin 2010: 134).

DiAgNOSIS. — "Mit den Familienmerkmalen. Gehäuse ellipsoidal. An den Polarregionen (lange Achse) treten 1-2 mehr Schalen auf als äquatorial (kurze Achse). Stacheln zahlreich, dreikantig, über die ganze Schale verteilt. Ausbildung der Mikrosphäre und ihrer unmittelbaren Umgebung nicht bekannt." (Kozur \& Mostler 1989: 218).

DiAGNOSIS (English translation by Jörg Maletz). - "As with family, ellipsoidal body. At the polar regions (long axis) occur 1-2 more shells than equatorial (short axis). Spines numerous, triangular, spread over the entire shell. Structure of the microsphere and its immediate surroundings is not known."

Klaengspongus Sashida in Sashida, Salyapongse \& Nakornsri, 2000 sensu Maldonado \& Noble (2010)

Klaengspongus Sashida in Sashida, Salyapongse \& Nakornsri, 2000: 256. - Maldonado \& Noble 2010: 106.

Spongosphaeradiscus Wang in Wang \& Shang, 2001: 118.

TYPe sPeCIES. - Klaengspongus spinosus Sashida in Sashida, Salyapongse \& Nakornsri, 2000 (Sashida et al. 2000: 256, pl. 3, fig. 7-8).

AgE AND location of TyPe MATERIAL. - Upper Permian (Changhsingian), Eastern Thailand.

TAXON CODE. -244 .

STATUS. - Valid.

DiAGNOSIs. - "Large, discoidal, spongy shell with short conical spines in the equatorial plane. Central cavity shallow, flanked by deep depression." (Sashida in Sashida et al. 2000: 256).

\section{REMARKS}

Maldonado \& Noble (2010) emended the diagnosis to include forms lacking equatorial spines, and also included details about the concentric internal shells surrounding the inner cavity. 
Paracopicyntra Feng in Feng He, Gu, Jin \& Meng, 2006 Paracopicyntra Feng in Feng, He, Gu, Jin \& Meng, 2006a: 25.

TyPE SPECIES. - Copicyntra ziyunensis Feng \& Gu, 2002 (Feng \& Gu 2002: 803, fig. 4.12, 5.1-5.7).

AgE AND LOCATION OF TYPE MATERIAL. - Uppermost Changhsingian, southern Guizhou, southwestern China.

TAXON CODE. -245 .

STATUS. - Valid.

DiAGNOSIS. - "Test subspherical, with numerous spines. Outer shell spongy, with very small pores; innermost shell large; four to seven (usually four to five) concentric shells occur between outer and medullary shell. An initial spicule is located at the central part of the medullary shell." (Feng in Feng et al. 2006a: 25).

\section{Paurinella Kozur \& Mostler, 1981}

Paurinella Kozur \& Mostler, 1981: 49.

Type SPeCIES. - Paurinella curvata Kozur \& Mostler, 1981 (Kozur \& Mostler 1981: 49, pl. 4, fig. 3, 6).

AgE AND LOCATION OF TYPE MATERIAL. - Anisian-Ladinian, Recoaro, Passo della Gabiola, Italy Taxon code: 246.

STATUS. — Valid.

DiAGNOSIs. - "Schale spongiös, sphärisch bis subsphärisch, stets mit mehr als 10 konzentrisch angeordneten Schichten um eine winzige Mikrosphäre. Die drei Hauptstacheln sind rund und liegen in einer Ebene, z.T. sind sie gebogen.” (Kozur \& Mostler 1981: 49).

DiagnOsis (English translation J. P. Caulet - RadWorld database). "Spongy shell, spherical to sub-spherical, invariably with more than ten concentrically arranged spheres around a tiny microsphere. The three main spines are round and are located in a plane, and are sometimes bent."

Spongosphaeradiscus Wang in Wang \& Shang, 2001

Spongosphaeradiscus Wang in Wang \& Shang, 2001: 118.

TYPE SPECIES. - Spongosphaeradiscus shaiwaensis Wang in Wang \& Shang, 2001 (Wang \& Shang 2001: 118, pl. 1, fig. 24-33, holotype not designed, best specimen pl. 1, fig. 27).

Age and location of type Material. - Upper Permian, Shaiwa Group, Guizhou, China.

TAXON CODE. -247 .

STATUS. - Junior synonym of Klaengspongus Sashida, Salyapongse, and Nakornsri, 2000 (by Maldonado \& Noble 2010: 106).

DiagnOSIS. - "Shell bi-convex, lenticular in lateral view, composed of one central sphere with discoidal margin and marginal spines. Sphere and disc spongy, spines cone-form, short and three-bladed." (Wang in Wang \& Shang 2001: 118).

\section{REMARKS}

Maldonado \& Noble (2010) placed this genus in synonymy, but misspelled the name as Spongosphaerodiscus.
Tamonella Dumitrica, Kozur \& Mostler, 1980

Tamonella Dumitrica, Kozur \& Mostler, 1980: 7.

TyPE SPECIES. - Tamonella multispinosa Dumitrica, Kozur \& Mostler, 1980 (Dumitrica et al. 1980: 7, pl. 10, fig. 1, 3, 8).

AgE AND LOCATION OF TYPE MATERIAL. - Upper Anisian - lower Ladinian, Southern Alps, area of Recoaro and Tretto, Italy.

TAXON CODE. -248 .

STATUS. - Valid.

DiAGNOSIS. - "Elongated-ellipsoidal spongy shell. Spongy network arranged in many layers. Microsphere minute. The numerous (mostly more than 10) spines are rather short, needle-like and situated only in the pole areas. They all have nearly the same length" (Dumitrica et al. 1980: 7).

\section{Tetrapaurinella Kozur \& Mostler, 1994}

Tetrapaurinella Kozur \& Mostler, 1994: 76.

TYPE SPECIES. - Tetrapaurinella discoidalis Kozur \& Mostler, 1994 (Kozur \& Mostler 1994: 77, pl. 16, fig. 9, pl. 17, fig. 4, 6).

Age And location of TyPe MATERIAL. - Lower Fassanian Spongosilicarmiger italicus Zone, San Ulderico, Southern Alps, Italy.

TAXON CODE. - 249 .

STATUS. — Valid.

DiAGNOSIS. - "Shell discoidal, inflated discoidal or subspherical, consisting of several spongy layers around a microsphere. 4 needlelike main spines in cross-like arrangement, situated in one plane or with slightly tetrahedral arrangement." (Kozur \& Mostler 1994: 76).

Family Haplotaeniatidae Won, Blodgett \& Nestor, 2002

Haplotaeniatumidae - Won et al. 2002: 959 (nom. correct. Maletz [2011a: 130]).

\section{Gyrosphaera Noble \& Maletz, 2000}

Gyrosphaera Noble \& Maletz, 2000: 267.

TyPe SPECIES. - Gyrosphaera raneatela Noble \& Maletz, 2000 (Noble \& Maletz 2000: 267, pl. 2, fig. 1-3).

AgE AND LOCATION Of TYPE MATERIAL. - Telychian (Llandovery, Lower Silurian), Dalarna, Sweden.

TAXON CODE. -250 .

STATUS. - Valid.

DiAGNOSIS. - "Large spherical to subspherical shell composed of loose labyrinthine mesh forming three or more spiral layers. Primary spines rod-shaped. Species vary in relative spine length, number of spines, and robustness of spines." (Noble \& Maletz 2000: 267).

\section{Haplotaeniatum}

Navarov \& Ormiston, 1987 in Nazarov, 1988 sensu Jones \& Noble (2006)

Haplotaeniatum Navarov \& Ormiston, 1987 in Nazarov, 1988: 66. - Nazarov 1988: 66 (nomen nudum). — Nazarov \& Ormiston 1990: 19; 1993: 40, 41. — Jones \& Noble 2006: 300. 
TYPe SPECIES. - Haplotaeniatum labyrintheum Nazarov \& Ormiston, 1990 (Nazarov \& Ormiston 1990: 20, pl. 1, fig. 5); Nazarov \& Ormiston 1993: 41, pl. 3, fig. 9-10.

AgE AND LOCATION OF TYPE MATERIAL. - Middle to upper Llandovery (Lower Silurian), Sakmarskaya Suite, Southern Urals, Bashkiria, Sakmara River, Bolshoe Abishevo village, Russia.

TAXON CODE. -251 .

STATUS. — Valid.

DiAgNOSIS. - “Внутренний каркас преАставмен тонкой шестилучевой спикумой. Неравномерное развитие апофизов на мучах на разАичном расстоянии друг от Аруга приводит к образованию нескольких грубогубчатых обомочек. Внешняя оболочка, а также несколько внутренних иногда пронизаны сквозным отверстием (пимом?). Внешних игл шесть. они короткие, стержневидные, часто развиты три-четыре иглы, реже одна или аве" (Nazarov 1988: 66).

SUBSEQUENTLY PUBLISHED DIAGNOSIS (in English). - As with family "Having several concentric or spiraliform internal shells, which are interpreted as having formed from apophyses developed on basal and proximal parts of the main spine." (Nazarov \& Ormiston 1993: 40).

\section{REMARKS}

As Nazarov (1988: 66) introduces Haplotaeniatum Navarov \& Ormiston, 1987 as a new genus and assigns but does not describe the type species Haplotaeniatum tegimentum Nazarov, 1984, the genus is then nomen nudum. In Nazarov \& Ormiston (1990) a different type species Haplotaeniatum labyrintheum Navarov \& Ormiston, 1990 is assigned this time with a description and a holotype GIN 4679/33 (although it is another specimen GIN $4679 / 34$ that is illustrated). This is followed in Nazarov \& Ormiston (1993) where a diagnosis for Haplotaeniatum is published in English together with that of the type species Haplotaeniatum labyrintheum. This time, a paratype GIN $4679 / 34$ is illustrated (Nazarov \& Ormiston 1993: pl. 3, figs 9, 10). By order of priority the 1990 introduction of the genus is the first that can be regarded as valid.

Won et al. (2002) emended the diagnosis to better describe the internal structure, a proloculus, overlain by labyrinthine material, which could be distinctly layered to non-layered. Won et al. (2002) also included taxa from the genus Orbiculopylorum that had a distinct gap between outer and inner layers. Jones \& Noble (2006) introduced emendations that removes forms with a distinct medullary and cortical area, restricting it to forms with weak labyrinthine to discontinuous spiraliform layering, that can occur with or without major spines.

\section{Labyrinthosphaera Noble \& Maletz, 2000}

\section{Labyrinthosphaera Noble \& Maletz, 2000: 268.}

TYPE SPECIES. - Labyrinthosphaera macdonaldi Noble \& Maletz, 2000 (Noble \& Maletz 2000: 268, pl. 2, fig. 6-11).

AgE AND LOCATION OF TYPE MATERIAL. - Telychian (Llandovery, Lower Silurian), Dalarna, Sweden.

TAXON CODE. -252 .
STATUS. - Valid.

DiAGNOSIS. - "Multi-layered labyrinthine radiolarian with six to twelve long, tri-bladed primary spines; with or without secondary spines." (Noble \& Maletz 2000: 268).

Orbiculopylorum Noble, Braun \& McClellan, 1998

Orbiculopylorum Noble, Braun \& McClellan, 1998: 718.

TYPE SPECIES. - Orbiculopylorum marginatum Noble, Braun \& McClellan, 1998 (Noble et al. 1998: 719, fig. 4.1).

AgE AND LOCATION OF TYPE MATERIAL. - Lower Llandovery (Lower Silurian), Garden Pass, northern Adobe Range, Nevada, USA.

TAXON CODE. -253 .

STATUS. - Valid.

DiAgNOSIS. - "Large spherical spumellarian with a prominent pylome on the cortical shell and a medullary structure consisting of a loose concentric meshwork supported by and connected to primary radial beams." (Noble et al. 1998: 718).

Family INANIGUTTIDAE Nazarov \& Ormiston, 1984 sensu Danelian \& Popov (2003)

\section{REMARKS}

We follow the revised diagnosis of this family, by Danelian \& Popov (2003: 332): "The family is here emended to include forms characterised by the presence of three shells, such as the new genus Triplococcus, and some Upper Ordovician forms mentioned by Webby \& Blom (1986)."

\section{Aciferopylorum Nazarov \& Ormiston, 1990}

Aciferopylorum Nazarov \& Ormiston, 1990: 90. — Nazarov \& Ormiston in Nazarov 1988: 71 (nomen nudum).

TYPE SPECIES. - Aciferopylorum admirandum Nazarov \& Ormiston, 1990: 22, pl. 1, fig. 7 (Nazarov \& Ormiston, 1993: 43, pl. 4, fig. 9).

AgE AND LOCATION OF TYPE MATERIAL. - Wenlock? - Ludlow (Silurian), Tarangul River, Aktyubinsk Region, Southern Urals, Russia.

TAXON CODE. -254 .

STATUS. - Junior synonym of Fusalfanus Furutani, 1990 (by Tetard et al. 2015).

DiAgNOSIS. - “Раковина сферическая, реже эмлипсовидная, с хорошо развитыми внутренней и многочисленными внешними иглами. Пимом небольшой, обрамленный несколькими иглами. Строение внутреннего каркаса неясно." (Nazarov \& Ormiston in Nazarov 1988: 71).

DiAGNOSIS (English translation in Nazarov \& Ormiston 1993). "Shell spherical, less frequently elliptical, with well-developed internal and numerous external spines. Pylome small, framed by few spines. Internal shell structure not clear".

REMARKS

A diagnosis for the genus is provided in Nazarov (1988: 71) and this is what appears above. Aciferopylorum admirandum 
Nazarov \& Ormiston, 1990 is listed therein as the type species but is not described in that paper. It is subsequently described in Nazarov \& Ormiston (1990: 22) with an English language translation of the diagnosis for the genus given in Nazarov \& Ormiston (1993: 43). Tetard et al. (2015) note that the type species is likely a junior synonym of Fusalfanus osobudaniensis Furutani, 1990.

\section{Cessipylarum Nazarov in Afanasieva, 1986}

Cessipylarum Nazarov in Afanasieva, 1986: 30.

Type SPECIES. - Pylentonema insueta Nazarov, 1975 (Nazarov 1975b: 97, pl. 21, fig. 6-7).

Age ANd LOCATION OF TYPE MATERIAL. - Middle Ordovician, upper Dapingian, eastern Kazakhstan. Chagan River.

TAXON CODE. -255 .

STATUS. - Junior synonym of Kalimnasphaera Webby \& Blom, 1986 (herein).

Diagnosis. - "Раковина субсферическая, стенка пористая. Внутренний каркас представлен полой, непористой сферой с отходящими от нее семью кучами. В некоторых случаях на мучах внутреннего каркаса отмечается развитие апофизов, имеющих тенденцию к соединению и образованию второй, внутренней, частично развитой оболочки. Раковина несет семь основных конусовидных игл, из которых две находятся около пилома, а остальные пять расположены приблизительно под углом $90^{\circ}$ Аруг к Аругу по всей поверхности скемета. Аополнитемьные иглы развиты на узмах межпоровой решетки. Пимомное отверстие окаймкено утолщенным валиком и двумя основными иглами." (Nazarov in Afanasieva 1986: 30).

DiAGNOSIS (English translation). - " "Spherical shell, porous wall. Internal shell represented by a hollow, non-porous sphere with seven rays. In some cases, on the rays of the inner framework some apophyses that can unite to form a second, inner and incomplete shell can be observed. The shell has seven conical spines, two of which are around the pylome and the remaining five are located at approximately $90^{\circ}$ angles to each other over the entire skeleton. Additions spines are developed on the porous lattice. Pylome surrounded by thickened cylindrical spines and by the two main spines."

\section{REMARKS}

This may be a misspelling of the genus Cessipylorum, yet the type species designated (Pylentonema insueta Nazarov, 1975) is different to that of Cessipylorum (Pylentonema aperta Nazarov, 1975). Nonetheless, Kalimnasphaera has priority because the date of publication. Webby \& Blom (1986; publication in January) precedes Afanasieva (1986).

\section{Cessipylorum Nazarov \& Ormiston in Nazarov, 1988 sensu Nazarov \& Ormiston (1993)}

Cessipylorum Nazarov \& Ormiston in Nazarov, 1988: 70. — Nazarov \& Ormiston 1993: 43.

TYPE SPECIES. - Pylentonema aperta Nazarov in Nazarov, Popov \& Apollonov, 1975 (Nazarov et al. 1975: 102, pl. 1, figs 1, 2).
Age And location of type material. - Middle Ordovician, Central Kazakhstan.

TAXON CODE. -256 .

STATUS. - Junior synonym of Kalimnasphaera Webby \& Blom, 1986 (Noble \& Webby 2009: 559).

DiAgNOSIS. - “Внутренний каркас расположен в центре и представлен полой сферой с шестью-семью, реже менее, кучами, отходящими от нее. ОАна сферическая, пористая оболочка диаметром до 200 мкм. Иногда на мучах спикулы во внутренней полости сферы развиты апофизы, имеющие тенденции ксоединению и образованию внутренней, частично развитой сферы. Внешние основные иглы стержневидной формы." (Nazarov \& Ormiston in Nazarov 1988: 70 ).

DiAGNOSIS (English translation). - " Inner shell is located in the center and represented by a hollow sphere with six-seven, rarely less rays radiating from it. A spherical latticed shell diameter of 200 microns. In some specimens, the inner rays develop apophyses that form an internal, partially developed shell. Externally the main spines rod-shaped."

\section{REMARKS}

Nazarov \& Ormiston (1993) provide a more detailed diagnosis (?revision) as follows "Shell subspherical, wall pored. Internal framework a hollow, imperforate sphere 30 to $40 \mu \mathrm{m}$ in diameter with seven rays emanating from it. In some cases there is development of apophyses on the rays of the internal framework. These apophyses tend to coalesce and form a second, partially developed internal shell. The outer shell carries seven main conical spines, two of which are situated around the pylome; the remaining five are arrayed at angles of approximately $90^{\circ}$ to each other over the entire external shell surface. Secondary spines developed at the corners of the interpore lattice. Pylomal opening bordered by a thickened lip and two main spines." This description is similar to that of Cessipylarum, which signifies that the two genera represent a single genus, misspelled in one case.

\section{Fusalfanus Furutani, 1990}

Fusalfanus Furutani, 1990: 38.

Aciferopylorum Nazarov \& Ormiston, 1990: 21.

TYPE SPECIES. - Fusalfanus osobudaniensis Furutani, 1990 (Furutani 1990: 38, pl. 5, fig. 2-5).

AgE AND LOCATION OF TYPE MATERIAL. - Wenlock or Ludlow (Silurian), Horizons O-1, -2, -3, Osobudani Valley, Horizon F-3, Fukuji area, Gifu Prefecture, Japan.

TAXON CODE. -257.

STATUS. - Valid.

Diagnosis. - "Cortical shell is spongy with a pylome, a delicate lattice shell may be developed at the outside of the spongy cortical shell. Medullary shells are doubled, latticed. Spines strongly tapered at the proximal part. The longitudinal section of the spines are concave" (Furutani 1990: 38). 
Futobari Furutani, 1990

Futobari Furuani, 1990: 34.

TYPe SPECIES. - Futobari solidus Furutani, 1990 (Furutani 1990: 34, pl. 1, fig. 1-4).

Age AND Location of tYPE MATERIAL. - Silurian, Horizons O-6, O-9, Osobudani Valley, Horizons I-1, -2, -4, -6, -7, -8, -9, -10, Ichinotani Valley, Fukuji area, Gifu Prefecture, Japan.

TAXON CODE. -258 .

STATUS. - Valid.

DiAgNOSIs. - "Cortical shell latticed, single. Medullary shell latticed, doubled. Spines thick, may be grooved at the proximal part. (The disposition of spines are more or less irregular.) Spines are not very regularly disposed." (Furutani 1990: 34).

\section{Helminentactinia Li, 1994}

Helminentactinia Li, 1994: 268.

TyPe SPECIES. - Helminentactinia nazarovi Li, 1994 (Li 1994: 268, pl. I, figs 12, 16, 19).

Age And location of type Material. — Middle Silurian, Keerhada, Xinjiang western China.

TAXON CODE. -259 .

STATUS. — Junior synonym of Zadrappolus Furutani, 1990 (herein).

DiAGNOSIS. - "Shell large, lenticular or sublenticular, circular or subcircular in outline. Two cortical shells and one inner shell ellipsoidal. Outer cortical shells with numerous spines and pores. Inner shell with some rod-like crossbeams which cross from long spines to inner shell." (Li 1994: 268).

\section{REMARKS}

Li distinguishes this genus from other Inaniguttid genera based on its lenticular shell. We regard this as unlikely and more probably it is a flattening effect resulting from compaction. Thus we consider it synonymous with Zadrappolus based on spine number and shape.

\section{Inanibigutta Nazarov \& Ormiston in Nazarov, 1988}

Inanibigutta Nazarov \& Ormiston in Nazarov, 1988: 56.

TYPE SPECIES. - Entactinosphaera aksakensis Nazarov, 1975 (Nazarov 1975b: 68, pl. 16, fig. 4-8, pl. 21, fig. 2).

AgE AND LOCATION OF TYPE MATERIAL. - Upper Dapingian - lower Sandbian (Middle Ordovician), Bestomakskaya series, southwestern foothills of the Chingiz mountain range, Chagan River, Eastern Kazahstan.

TAXON CODE. -260.

STATUS. - Valid.

DiAgNOSIS. - “Внутренний каркас представцен полой сферой, неперфорированной, диаметром 40-55 мкм или ее модификациями с шестью кучами, отходящими от нее. Аве оболочки. Внутренняяпористая, Аиаметром 85-105 мкм, внешняя также пористая, иногда с второстепенными иглами. Шесть основных игл, иногда менее." (Nazarov \& Ormiston in Nazarov 1988: 56).

DiAGNOSIS (English translation by J. P. Caulet RadWorld database). - "Inaniguttidae having two primarily porous shells and six main spines, which are associated with hollow or solid rays of the internal sphere (or its modifications), which occupies a central position or is only slightly eccentric".

\section{Inanigutta Nazarov \& Ormiston, 1984}

Inanigutta Nazarov \& Ormiston, 1984: 72.

TyPe sPeCIES. - Entactinia unica Nazarov, 1975 (Nazarov 1975b: 54, pl. 15, fig. 9-10, pl. 20, fig. 1).

AgE AND LOCATION OF TYPE MATERIAL. - Upper Dapingian-lower Sandbian (Middle Ordovician), Bestomakskaya Series Chagan river, southwestern foothills of the Chingiz ridge, Eastern Kazakhstan.

TAXON CODE. -261.

STATUS. - Valid.

DIAGNOSIS. - "Inaniguttidae с одной преимущественно пористой оболочкой и 6 иглами, которые связаны с полыми или смошными Аучами внутренней сферы, занимащей центральное положение (рис.I, a)." (Nazarov \& Ormiston 1984: 72).

DiAgNosis (English translation by J. P. Caulet). — "Internal structure represented by a hollow non porous sphere of a diameter 40-60 $\mu \mathrm{m}$, rarely less, with six rays emanating from it at angles of approximately $120^{\circ}$. A single, thick, mostly porous, envelope of a diameter up to $350 \mu \mathrm{m}$. Six main spines, rarely four to five."

\section{Inanihella Nazarov \& Ormiston, 1984}

Inanihella Nazarov \& Ormiston, 1984: 72.

TYPE SPECIES. - Helioentactinia bakanasensis Nazarov 1975b (Nazarov 1975b: 89, pl. 19, fig. 9-13).

Age and location of type Material. - Upper Cambrian (?), Ushkyzyljskaya series, Ushkyzyl mountains, Eastern Kazakhstan.

TAXON CODE. -262 .

STATUS. - Valid.

DiAGNOSIS. - "Inaniguttidae c 2 преимущественно пористыми сближенными оболочками и многочисленными внешними стержневидными иглами, которые связаны со сплошными кучами внутреннего каркаса, расположенного в центре раковины (рис.I, 2)." (Nazarov \& Ormiston 1984: 72).

Diagnosis (English translation by J.P. Caulet). — "Internal structure spherical or spheroidal $(45-55 \mu \mathrm{m})$ with many rod-like rays originating from it. Two porous external shells, located close together, diameter of the internal one 200-220 $\mu \mathrm{m}$, external shell sometimes with a pylome. In some species occurrence of many external main spines with hollowed bases (furrows)."

Kalimnasphaera Webby \& Blom, 1986

Kalimnasphaera Webby \& Blom, 1986: 152. 
Cessipylarum Nazarov in Afanasieva, 1986: 30 (n. syn.)

Cessipylorum Nazarov \& Ormiston in Nazarov, 1988: 70.

TyPE SPECIES. - Kalimnasphaera maculosa Webby \& Blom, 1986 (Webby \& Blom 1986: 152, fig. 3.4-3.9, 4.1-4.8).

AGE AND LOCATION OF TYPE MATERIAL. - Upper Ordovician, Malongulli Formation, central New South Wales, Australia.

TAXON CODE. - 263.

STATUS. - Valid.

DiAGNOSIS. - “'Palaeoactinommid' with two delicate inner, reticulate medullary shells, a strong reticulate and pylomate cortical shell (both medullary and cortical shells composed of pore bars), and a loosely fenestrate outer shell, this latter preserved in varying degrees of completeness. Three to six long, gently tapering buttressed main spines arise from cortical shell. Radial beams cross spaces between medullary and cortical shells, but do not extend inwards, beyond medullary shells. Numerous By-spines occupy space between corti$\mathrm{cal}$ and outer fenestrate shells. Outer shell is only complete in areas where lateral spinules are linked to by-spines and main spines." (Webby \& Blom 1986: 152).

\section{Oriundogutta Nazarov \& Ormiston in Nazarov, 1988}

Oriundogutta Nazarov \& Ormiston in Nazarov, 1988: 57.

TYPe SPECIES. - Astroentactinia ramificans Nazarov, 1975 (Nazarov 1975b: 87, pl. 19, fig. 2-6, pl. 21, fig. 3-5).

AgE AND LOCATION OF TYPE MATERIAL. - Upper Dapingian-lower Sandbian (Middle Ordovician), Bestomakskaya series, southwestern foothills of the Chingiz mountain range, Chagan river, East Kazahstan.

TAXON CODE. - 264 .

STATUS. — Valid.

DiAGNOSIS. - “Внутренний каркас в виде полой непористой сферы (45-55 мкм) с многочисленными кучами, отходящими от нее. ОАна пористая толстостенная наружная оболочка Ао 250-300 мкм. Внешние иглы многочисленные, от восьми до двадцати, реже более." (Nazarov \& Ormiston in Nazarov 1988: 57).

DiAGNOSIS (English translation by J. P. Caulet - RadWorld database). - "Internal structure as a hollow sphere non porous (45$55 \mu \mathrm{m}$ ) with many rays originating from it. One external shell porous and thick up to $250-300 \mu \mathrm{m}$. Many external horns, from 8 to 20 , or more."

\section{Plussatispila MacDonald, 2006}

Plussatispila MacDonald, 2006a: 33.

TyPe SPECIES. - Plussatispila magnilimax MacDonald, 2006 (MacDonald 2006a: 33, fig. 3.1, 3.3, 3.5, 6.15).

AgE AND LOCATION OF TYPE MATERIAL. - Upper Llandovery (griestoniensis Zone) of the Cape Phillips Formation, Cornwallis Island, Nunavut, Canada.

TAXON CODE. -265 .

STATUS. - Valid.
DiAGNOSIS. - "Central microsphere; two concentric lattice shells, distinctly separated; additional shells may be present; seven or more rod-like spines develop at second shell, connected by rays to microsphere." (MacDonald 2006a: 33).

Triplococcus Danelian \& Popov, 2003

Triplococcus Danelian \& Popov, 2003: 333.

TyPe SPECIES. - Triplococcus acanthicus Danelian \& Popov, 2003 (Danelian \& Popov 2003: 333, fig. 5g-m, 6a-c).

AGE AND LOCATION OF TYPE MATERIAL. - Floian (uppermost Lower Ordovician), Chu-Ili Range, west Balkhash Region, Kazakhstan.

TAXON CODE. -266.

STATUS. — Valid.

DiAGNOSIS. - "Inaniguttid radiolarians consisting of three nearly perfectly spherical shells. 5-6 primary rod-like spines are arranged radially, which join themselves at the central part of the skeleton. Numerous secondary spines originating from the external surface of the inner shells are present and taper rapidly distally." (Danelian \& Popov 2003: 333).

\section{Zadrappolus Furutani, 1990}

Zadrappolus Furutani, 1990: 35.

Helminentactinia Li, 1994: 268 (n. syn.)

TYPE SPECIES. - Zadrappolus yoshikiensis Furutani, 1990 (Furutani 1990: 35, pl. 2, fig. 4-6, pl. 3, fig. 1-2).

Age and Location of type Material. - Silurian, Horizons O-6, -9 , Osobudani Valley, Horizons I-1, -2, -3, -4, -5, -6, -7, -8, -10, Fukuji area, Gifu Prefecture, Japan.

TAXON CODE. -267 .

STATUS. — Valid.

DiAGNOSIS. - "Inaniguttidae with a single cortical shell and double medullary shells, and numerous, more than 10 on a hemisphere, spines. Spines usually cylindrical, needle-like, or conical, and may be bladed at the base." (Furutani 1990: 35).

\section{Family incertae sedis}

\section{Franklinia Jones \& Noble, 2006}

Franklinia Jones \& Noble, 2006: 308.

TyPE SPECIES. - Franklinia tricae Jones \& Noble, 2006 (Jones \& Noble 2006: 310, pl. 5, fig. 2-7, pl. 7, fig. 5, 6, 8).

AGE AND LOCATION OF TYPE MATERIAL. - Sheinwoodian, uppermost Lower Silurian, Cape Phillips Formation, Nunavut, Artic Canada.

TAXON CODE. -268 .

STATUS. - Homonym.

Diagnosis. - "Hollow, thin shell base overlain by loose labyrinthine layer. Six or more thin rod-shaped primary spines per 
hemisphere are rooted on surface of shell base but do not penetrate. Very short secondary spines may be present." (Jones \& Noble 2006: 308)

\section{REMARKS}

This species is a junior homonym of the bird Franklinia Blyth, 1863. See Maletzella nomen novum Noble, 2014.

\section{Haplopolus Li, 1994}

Haplopolus Li, 1994: 270.

TYPE SPECIES. - Haplopolus dipolus Li, 1994 (Li 1994: 270, pl. 1, fig. 1).

Age And location of TYPE MATERIAL. — Middle Silurian, Keerhada, Xinjiang western China.

TAXON CODE. -269 .

STATUS. - Junior synonym of Pseudospongoprunum Wakamatsu, Sugiyama \& Furutani, 1990.

DiAGNOSIS. - "Test subspherical or ellipsoidal, with spongy cortical shell and one spongy inner shell, two or more polar spines on one plane. Surface of cortical shell with strong bar and circular pores" (Li 1994: 270)

\section{REMARKS}

This genus falls within the range of morphology for the Silurian genus Pseudospongoprunum and is treated as a junior synonym.

\section{Hegleria Nazarov \& Ormiston, 1985 sensu Noble \& Jin (2010)}

Hegleria Nazarov \& Ormiston, 1985: 22. — Noble \& Jin 2010: 142.

TYPE SPECIES. - Hegleria mammifera Nazarov \& Ormiston, 1985 (Nazarov \& Ormiston 1985: 22, pl. 6, fig. 3-5, junior synonym of Hegleria mammilla Sheng \& Wang, 1985); Noble \& Jin 2010: 142 .

Age AND LOCATION OF TYPE MATERIAL. — Guadalupian (Upper Permian), Lamar Limestone, West Texas, USA.

TAXON CODE. -270 .

STATUS. — Valid.

DiAGNOSIS. - As with subfamily "Spongentactiniines with three spongy shells, of which the outer bears numerous orderly arranged, raised mammae with hairlike cylindrical central spinules. Multiple internal rays (at least 12) connect the shells. Internal spicule not presently known" (Nazarov \& Ormiston 1985: 22).

\section{REMARKS}

This genus was originally placed within the Entactinaria and thought to have an internal spicule. Noble \& Jin (2010), based on a re-examination of recollected material from the type locality, emended the diagnosis describing the shell as spherical to globular with a doubled spongy medullary shell and a multi-layered spongy cortical shell.
Intracorpus Won, 1997

Intracorpus Won, 1997a: 366.

TyPE SPECIES. - Intracorpus octaedron Won, 1997 (Won 1997a: 366, pl. 5, fig. 13-16).

Age And location of tyPe MATERiAl. - Frasnian (Upper Devonian), Gogo Formation, Canning Basin, Western Australia.

TAXON CODE. -271 .

STATUS. - Valid.

DiAGNOSIS. - "A spherical to polygonal spongy shell with an internal polyhedral framework, no apophyses present." (Won 1997a: 366).

Maletzella Noble, 2014

Maletzella Noble, 2014: 35.

TyPE SPECIES. - Franklinia tricae Jones \& Noble, 2006 (Jones \& Noble 2006: 310, pl. 5, fig. 2-7, pl. 7, fig. 5, 6, 8).

AgE AND LOCATION OF TYPE MATERIAL. - Sheinwoodian (uppermost Lower Silurian), Cape Phillips Formation, Nunavut, Canada.

TAXON CODE. -272 .

STATUS. — Valid; replacement name for Franklinia.

DiAGNOSIs. — see Franklinia Jones \& Noble, 2006.

\section{Pseudospongoprunum}

Wakamatsu, Sugiyama \& Furutani, 1990

Pseudospongoprunum Wakamatsu, Sugiyama \& Furutani, 1990: 172.

TYPe SPECIES. - Pseudospongoprunum tazukawaensis Wakamatsu, Sugiyama \& Furutani, 1990 (Wakamatsu et al. 1990: 173, pl. 2, fig. 1-4).

Age AND LOCATION OF TYPE MATERIAL. - Pseudospongoprunum tazukawaensis assemblage middle Wenlock-middle Ludlow (Silurian), Kurosegawa tectonic zone, southwest Japan.

TAXON CODE. -273.

STATUS. - Valid.

SYNONYM. - Haplopolus Li, 1994.

DiAGNOSIS. - "Spongy shell with two polar spines. Shell subspherical to elliptical in shape, with numerous circular to oval pores of irregular size. Spongy structure filling the inside of the shell without symmetric structures. Two polar spines originating from poles of shell, rod-like to conical, tapering distally. Cross section of spines circular to polygonal. Proximal parts of spines occasionally blade-like. The spines without directly connecting each other at the inside of the shell. One polar spine usually longer than the other." (Wakamatsu et al. 1990: 172).

Quasibeothuka Wang in Wang, Cheng \& Zhang, 2008

Quasibeothuka Wang in Wang, Cheng \& Zhang, 2008: 399. 
TYPE SPECIES. - Quasibeothuka fusiforma Wang in Wang, Cheng \& Zhang, 2008 (Wang et al. 2008: 399, pl. 1, fig. 1-4).

Age And location of type material. - Ordovician, Kurutag region, Xinjiang, western China.

TAXON CODE. -274 .

STATUS. — nomen dubium (herein).

DiagnOSIS. - "Hollow spongy shell fusiform, ovate and elliptic. Small pores are on shell surface. There are two rod-like polar spines, one more robust, cone-shaped and other delicate, longer." (Wang in Wang et al. 2008: 399).

\section{REMARKS}

The type material figured by Wang et al. (2008) is very poorly preserved and on none of the figured specimens is it possible to discern the characteristics that define this putative genus.

\section{Zhuangodiscus Wu \& Feng in Wu, Feng, Gui \& Liu, 2010}

Zhuangodiscus Wu \& Feng in Wu, Feng, Gui \& Liu, 2010: 887.

Type sPecies. - Zhuangodiscus orthacanthus Wu \& Feng in Wu, Feng, Gui \& Liu, 2010 (Wu et al. 2010: 887, fig. 9.8-9.18).

Age AND location of TYPE MATERial. - Upper Changhingian (Upper Permian), Dalong Formation at Balong, Fusui County, Southern Guangxi, south China.

TAXON CODE. -275 .

STATUS. - Valid.

DiagnOSIs. - "Test inflated, discoidal, consisting of fine, dense, concentric spongy shells, with 2 to 6 equatorial spines. Spine large, short conical or long cylindrical lateral profile, having three longitudinally arranged primary ridges alternating with three longitudinally arranged primary grooves; a primary ridge has two or three secondary longitudinal ridges and one or two secondary longitudinal grooves; its base is usually covered by spongy structure and many pores evident along the grooves when the spongy structure is absent; spinal shaft well developed." (Wu \& Feng in Wu et al. 2010: 887).

\section{Order incertae sedis}

\section{Family CORYTHOECIDAE \\ Nazarov in Nazarov \& Rudenko, 1981}

Corythoecidae Nazarov in Nazarov \& Rudenko, 1981: 137.

\section{Arrectoalatus Nazarov \& Ormiston, 1985}

Arrectoalatus Nazarov \& Ormiston, 1985: 49.

TYPe SPECIES. - Arrectoalatus cernuus Nazarov \& Ormiston, 1985 (Nazarov \& Ormiston 1985: 49, pl. 4, fig. 10, text-fig. 12).

Age AND location of type MATERial. - Gzhelian, Upper Carboniferous, Nikol village, Ural River, Southern Urals, Russia.

TAXON CODE. -276 .
STATUS. — Valid.

DiAGNOSIS. - "Segmented corithoeciid possessing segmented, porous shell. Arch-like curve of columellae developed only in the apical part. Junction with each other forming oval pylome (foramen) in upperpart of shell beneath which the bi-lobed wing is developed". (Nazarov \& Ormiston 1985: 49).

\section{REMARKS}

Arrectoalatus could very well be a junior synonym of Camptoalatus. The differences between them seem to be much smaller than between these two genera and between them and Cornum and Corythoecia.

\section{Camptoalatus Nazarov \& Rudenko, 1981}

Camptoalatus Nazarov \& Rudenko, 1981: 138.

TYPE SPECIES. - Camptoalatus monopterygius Nazarov \& Rudenko, 1981 (Nazarov \& Rudenko 1981: 138, pl. 1, fig. 11-13).

Age AND LOCATION OF TYPE MATERIAL. - Upper CarboniferousEarly Permian, south Urals, Russia.

TAXON CODE. -277 .

STATUS. - Valid.

DiAGNOSIS. - “Раковина сегментированная, перфорированная. Колумемлы соединяются в базальной и апикальной частях раковины. От места соединения колумемл в базальной части отходит массивное Авухлопастное крымо. Все сегменты раковины пронизаны двумя рядами пор". (Nazarov \& Rudenko 1981: 138).

DiAgNosis (English translation by J. P. Caulet - RadWorld database). - "Shell segmented, porous. Columellae joined at the apical and basal parts of the shell. At the junction level of the columellae in the basal part of the shell originates a robust bi-lobate wing. Two rows of pores on each segment of the shell."

\section{Cornum Schwartzapfel \& Holdsworth, 1996}

Cornum Schwartzapfel \& Holdsworth, 1996: 230.

TYPE SPECIES. - Cornum mittereri Schwartzapfel \& Holdsworth, 1996 (Schwartzapfel \& Holdsworth 1996: 246, pl. 36, fig. 1-5, 10, 15-19).

Age and location of type material. - Middle Chesterian/ lower Namurian (lower Carboniferous), Delaware Creek Member, "Caney" Shale, Southern Arbuckle Mountains, Oklahoma, USA.

TAXON CODE. -278 .

STATUS. - Valid.

DiAGNOSIS. — "Test as with subfamily; imperforate, segmented, asymmetrically conical (rarely symmetrically conical) in shape; subtriangular to rhamphoid-like in outline. Shell flattened, compressed parallel to the plane of bilateral symmetry. Shell half open with lateral slit developed along convex side of shell (in lateral view). Lateral slit continuous with basal aperture. Lamellar wing, situated above basal aperture, originating along convex side of shell between open portion of shell wall. Wing variable in size and shape. Columellae(?) present; not observed in material studied." (Schwartzapfel \& Holdsworth 1996: 230). 


\section{Corythoecia Foreman, 1963}

Corythoecia Foreman, 1963: 298.

TYPE SPECIES. - Corythoecia dichoptera Foreman, 1963 (Foreman 1963: 298, pl. 8, fig. 14, pl. 9, fig. 2a-c).

Age And location of TyPe material. - Upper Devonian, Huron member, Ohio Shale, USA.

TAXON CODE. -279 .

STATUS. - Valid.

DIAGNOSIS. - "Small, approximately conical shell with one or two longitudinal ribs in opposite sides of the shell wall. One bi-lobed lamellar wing extends laterally from the shell wall between the two ribs." (Foreman 1963: 298).

\section{Family Proventocitidae Aitchison, 1998}

Proventocitidae Aitchison, 1998: 77, 78

Archeoproventocitum Won, Iams \& Reed, 2007

Archeoproventocitum Won, Iams \& Reed, 2007a: 533.

TYPE SPECIES. - Archeoproventocitum nudiformum Won, Iams \& Reed, 2007 (Won et al. 2007a: 534, fig. 3.1, 8.1-8.4, 8.7, 8.8).

Age AND LOCATION OF TYPE MATERIAL. - Upper Tremadocian, Cow Head Group, western Newfoundland, Canada.

TAXON CODE. -280 .

STATUS. - Valid.

DiAGNOSIS. - "Spicular skeleton consisting of several sinuous rays with branches centered at the apical portion. Rays connected by an inter-ray bar(s) or an inter-ray loop. One to several inter-ray spines developed. Transformation of the spicule by development of fused rays and branches forming the meshwork of an apical or partially to completely closed shell wall." (Won et al. 2007a: 533).

\section{Cowheadia Won, Iams \& Reed, 2007}

Cowheadia Won, Iams \& Reed, 2007a: 535.

Type species. - Cowheadia duplextesta Won, Iams \& Reed, 2007 (Won et al. 2007a: 535, fig. 3.3, 10.10-10.16 [monotypy]).

Age AND LOCATION OF TYPE MATERIAL. - Upper Tremadocian, Cow Head Group, western Newfoundland, Canada.

TAXON CODE. -281

STATUS. - Valid

DiAgnOSIS. - "Proventocitiid spicule as the internal structure of a spherical shelled form; distal parts of rays and branches of the spicule protruding out of the shell wall as outer spines." (Won et al. 2007a: 535).
Protoproventocitum Won, Iams \& Reed, 2007

Protoproventocitum Won, Iams \& Reed, 2007a: 535.

TYPE SPECIES. - Protoproventocitum aitchisoni Won, Iams \& Reed, 2007 (Won et al. 2007a: 536, fig. 3.2, 8.6, 9.1-9.12, 10.1-10.4; designated herein; first named species).

Age AND LOCATION OF TYPE MATERIAL. - Upper Tremadocian, Cow Head Group, western Newfoundland, Canada.

TAXON CODE. -282 .

STATUS. - Valid.

DiAgnOSIS. - "Open or closed, conical to sub-conical shelled form with a well- or poorly developed apical portion. An internal transformed proventocitiid spicule present or incorporated into the meshwork of the shell wall. Shell wall spongy or one-layered with three, rarely two- dimensional meshwork. Apical shell wall distinguished by denser meshwork than that of the major part of shell wall. Meshwork commonly coarser toward antapical side. Outer spines highly variable in their position, length, and diameter." (Won et al. 2007a: 535, 536).

\section{Proventocitum Nazarov \& Ormiston in Nazarov, 1988 sensu Nazarov \& Ormiston (1993)}

Proventocitum Nazarov \& Ormiston in Nazarov, 1988: 71; Nazarov \& Ormiston, 1993: 43

TYPE SPECIES. - Popofskyellum? procerulum Nazarov in Nazarov \& Popov, 1980: 68, pl.15, fig. 4-9.

AgE AND LOCATION OF TYPE MATERIAL. — Ordovician, Kazakhstan.

TAXON CODE. -283 .

STATUS. - Valid.

DIAGNOSIS. - “ОАна яйцевидная пористая раковина (Ао 130x180 мкм) с 4-7 внешними стержневидными иглами. Обычно 2 небомьшие иглы обрамляют пимом, против которого развивается крупная апикальная игла. Остальные игла развиты в центральной части раковины. Строение внутренноего каркаса и его расположение не ясно.” (Nazarov 1988: 71)

REVISED DESCRIPTION. - Delicate conical, porous shell with four to seven, rarely more, external rod-like spines. Typically two small spines border the pylome. At the opposite pole of the shell are developed massive long, "apical" spines. The remaining spines are situated on the central part of the shell. The structure of the internal framework is unclear. Revised description in Nazarov \& Ormiston (1993: 43).

Family AspiculidaE Won, Iams \& Reed, 2005

Aspiculidae Won, Iams \& Reed, 2005: 440, 441.

Aspiculumidae - Won, Iams \& Reed, 2005: 438 (nom. correct. Maletz [2011a: 130]).

Neoaspiculumidae Won \& Iams, 2011: 164.

Aspiculum Won, Iams \& Reed, 2005

Aspiculum Won, Iams \& Reed, 2005: 441. 
TyPE SPECIES. - Aspiculum eccentricum Won, Iams \& Reed, 2005 (Won et al. 2005: 441, fig. 5.5-5.10a, 5.10b).

AgE AND LOCATION OF TYPE MATERIAL. - Lower-middle Tremadocian (Lower Ordovician), Cow Head Group, western Newfoundland, Canada.

TAXON CODE. -284 .

STATUS. — Valid.

DiAgNOSIS. - A spherical to subspherical or oval skeleton with or without pylome and no spicule system. Where the shell wall is spherical, the central (basal layer or innermost layer) part of the shell wall eccentrically developed and the thickness of the shell wall, therefore, varied within a single specimen. A basal layer developed or not, and its meshwork two- or three-dimensionally interwoven. (Won et al. 2005: 441).

\section{Cavasphaera Won \& Iams, 2015}

Cavasphaera Won \& Iams, 2015: 30.

TyPe SPECIES. - Cavasphaera diversa Won \& Iams, 2015 (Won \& Iams 2015: 30, pl.12, fig. 3).

AgE AND LOCATION OF TYPE MATERIAL. - Upper Floian (lower/ middle Arenig), Cow Head Group, western Newfoundland, Canada.

TAXON CODE. -285 .

STATUS. - Valid.

DiAgnosis. - "Multi-shelled spherical skeleton consisting of concentrically about three shells. An outermost shell layer with a spongy layer encrusting outer shell or appears as a distinct spherical layer. Outer shell two dimensionally latticed, and an inner hollow spherical shell present." (Won \& Iams 2015: 30).

\section{Neoaspiculum Won \& Iams, 2011}

Neoaspiculum Won \& Iams, 2011: 165.

TyPE SPECIES. - Neoaspiculum headense Won \& Iams, 2011 (Won \& Iams 2011: 165, fig. 6.1-6.10, 6.12-6.17).

AgE AND LOCATION OF TYPE MATERIAL. - Floian (Lower Ordovician), Cow Head Group, western Newfoundland, Canada.

TAXON CODE. -286

STATUS. — Valid.

DiAGNOSIS. - "Spherical pylomate or non-pylomate skeleton consisting of multiple layers, each of which is indistinctly or distinctly separated from the neighboring layer. Meshwork commonly composed of bars, bandages, rarely displaying wide interpore areas, all of these types rarely co-occurring within a specimen. Shape and degree of development of a proloculus variable." (Won \& Iams 2011: 165).

\section{Nyfrieslandia Maletz \& Bruton, 2007}

Nyfrieslandia Maletz \& Bruton, 2007: 278.

TyPe SPECIES. - Nyfrieslandia sphaeroidea Maletz \& Bruton, 2007 (Maletz \& Bruton 2007: 278, fig. 2B, C, H, 11G 20G, 25A-O, subsequently selected by Won \& Iams [2013: 27]).
AgE AND LOCATION OF TYPE MATERIAL. - Isograptus lunatus graptolite zone, Lower Ordovician, Spitsbergen.

TAXON CODE. -287.

STATUS. - Valid

DiAGNOSIS. — "Early spumellarian without a microsphere; a regular sphere is provided with numerous outer spines connected by slightly curved bars originating from apophyses, forming the incomplete, more irregular three-dimensional mesh of another sphere in most specimens; additional outer spheres may be developed." (Maletz \& Bruton 2007: 278)

\section{Sanctipaulelum Won \& Iams, 2015}

Sanctipaulelum Won \& Iams, 2015: 31.

TyPE SPECIES. - Sanctipaulelum pingue Won \& Iams, 2015 (Won \& Iams 2015: 31, pl.14, fig. 4).

AgE AND LOCATION OF TYPE MATERIAL. - Upper Floian (lower/ middle Arenig), Cow Head Group, Western Newfoundland, Canada.

TAXON CODE. -288

STATUS. - Valid

DiAGNOSIS. - "Skeleton with a thick shell wall consisting of several closely spaced and incompletely separated layers and an innermost hollow sphere with very delicate and open latticed mesh work." (Won \& Iams 2015: 31).

\section{Orders and Families incertae sedis}

Adamas Afanasieva, 2000

Adamas Afanasieva, 2000c: 85.

TYPE SPECIES. - Adamas cathedrarius Afanasieva, 2000 (Afanasieva 2000c: 85, pl. 90, fig. 1-8).

Age AND location of type Material. - Upper Devonian, TimanPechora Province, Russia.

TAXON CODE. -289 .

STATUS. - Homonym of the arthropod Adamas Malaise, 1945.

DiAgNOSIS. - “Раковина с Авумя оболочками: внешней губчатой и внутренней - решетчатой. Внутренний каркас преАставлен, по-видимому, многолучевой и/или осложненной апофизами спикулой. Продолжением кучей спикулы являются многочисленные (более 24) короткие стержневидные основные иглы, обрастающие губчатой тканью внешней оболочки скемета и принимающие вторично-конусовидною форму." (Afanasieva 2000c: 85)

Diagnosis (English translation by P. Dumitrica). — " "Test with two shells: outer - spongy and inner - porous. Internal skeleton represented, it seems, by multirayed and/or complex of apophyses of the spicule. Prolongations of the rays of the spicule result in numerous (more than 24) short cylindrical spines that form the spongy external meshwork of the skeleton and give raise to conical forms." (Afanasieva 2000c: 85). 


\section{Adamasirad Afanasieva, 2009}

Adamasirad Afanasieva, 2009: 115.

Replacement name for Adamas Afanasieva, 2009: 115.

TYPE SPECIES. - Adamas cathedrarius Afanasieva, 2000 (Afanasieva 2000c: 85, pl. 90, fig. 1-8).

Age AND location of type MATERIAL. - see Adamas Afanasieva, 2000.

TAXON CODE. -290.

STATUS. — Valid: replacement name for Adamas Afanasieva, 2000.

Diagnosis. - see Adamas Afanasieva, 2000.

Cancellientactinia Obut \& Shcherbanenko, 2008

Cancellientactinia Obut \& Shcherbanenko, 2008: 374.

TYPE SPECIES. - Cancellientactinia acifera Obut \& Shcherbanenko, 2008 (Obut \& Shcherbanenko 2008: 374, fig. 6A-D).

AgE AND LOCATION OF TYPE MATERIAL. - Uppermost GivetianUpper Frasnian (Devonian), Gornyak settlement, Altai-Sayan Folded Area, southwest Rudny Altai, Southwestern Siberia, Russia.

TAXON CODE. -290 .

STATUS. - Valid.

DIAGNOSIS. - " One spherical latticed shell, constructed by a meshwork of short bars. Inner skeleton represented by an 8-rayed spicule, all eight rays originating from a central point. Eight main more robust spines develop from rays of the internal spicule." (Obut \& Shcherbanenko 2008: 374).

\section{Caspiaza Afanasieva, 1986}

Caspiaza Afanasieva, 1986: 31.

TYPE SPECIES. - Caspiaza calva Afanasieva, 1986 (Afanasieva 1986: 31, pl. 1, fig. 1-11); Afanasieva 2000c: pl. 95, fig. 7.

AgE AND LOCATION OF TYPE MATERIAL. - Lower Carboniferous, Tien Shan, central Asia.

TAXON CODE. -292.

STATUS. — Valid.

DiAGNOSIS. - "Раковина субсферической или кувшиновидной формы, стенка губчатая. Поверхность раковины ровная или осложнена небольшими конусовидными дополнительными иглами. Пимомное отверстие окаймлено хорошо развитым перистомом в форме воротника." (Afanasieva 1986: 31).

DiAGNOSIS (English translation by J. P. Caulet - RadWorld database). - Shell sub-spherical or bottle-shaped, with a spongy wall. Surface of the shell smooth, or with small, conical, secondary spines. Peristomial aperture surrounded by a well-differentiated collar-shaped, peristome.
Copiconulus Feng in Feng, He, Gu, Jin \& Meng, 2006

Copiconulus Feng in Feng, He, Gu, Jin \& Meng, 2006a: 31.

Type SPECIES. - Copiconulus solidus Feng in Feng, He, Gu, Jin \& Meng, 2006 (Feng et al. 2006a: 31, pl. 4, fig. 1-8).

Age and location of type material. - Upper Permian, Dongpan section, southwest Guangxi, South China.

TAXON CODE. -293.

STATUS. - Valid.

DiAGNOSIS. - " "Test coniform, its height nearly equal to or slightly larger than maximum width. Outer shell spongy, with poorly or welldeveloped conical mammae, with or without spines. Pores small and subcircular. Spines short, three-bladed or rod-like. Inner shell small, spherical, spongy, and unclear in structure because of recrystallization. Shells between outer and inner shells thin, close to each other, coniform and connected by fine radial beams." (Feng in Feng et al. 2006a: 31).

\section{Etymalbaillella Li, 1995}

Etymalbaillella Li, 1995: 337.

TYPE SPECIES. — Etymalbaillella yennienii Li, 1995 (Li 1995: 338, pl. 1, fig. 4)

Age AND location of type Material. - Middle Ordovician, Darriwilian, Baijingsi, Qilian Mountains, China.

TAXON CODE. -294 .

STATUS. - Valid.

DiAGNOSIS. - "Test is oblique conical, two side of network shell with wings, pores arrangement is in oblique line, proximal of shell open." (Li 1995: 337, 338).

\section{Fungomacula Won in Won \& Below, 1999}

Fungomacula Won in Won \& Below, 1999: 336.

TYPe SPECIES. - Fungomacula barbatula Won in Won \& Below, 1999 (Won \& Below 1999: 336, pl. 9, fig. 8, 9, pl. 10, fig. 3).

Age and location of type material. - Middle Cambrian, Georgina Basin, Queensland, Australia.

TAXON CODE. -295.

STATUS. - Valid.

DiAgNOSIS. - "A spherical shell with a densely interwoven fine spongy meshwork and one or two spicules, each having four or six delicate rays, with or without outer spines, and sparsely distributed thin skeletal elements in the inner empty space between shell wall and rays." (Won in Won \& Below 1999: 336).

\section{Lithocannosphaeropsis Ormiston \& Lane, 1976}

Lithocannosphaeropsis Ormiston \& Lane, 1976: 174. — Deflandre 1960: 216 (nomen nudum).

TYPE SPECIES. - Lithocannosphaeropsis fallax Deflandre, 1960 (Deflandre 1960: 216, pl. 1, fig. 15). 
Age AND location of tYPe MATERIAL. - Visean, early Carboniferous, France.

TAXON CODE. -296.

STATUS. — Valid.

DiAgnosis. - "Polygonal meshwork of cortical shell consists of pentagons and irregular hexagons, occasionally subdivided by secondary struts, major pentagons ranging from 60 to $180 \mu \mathrm{m}$ in diameter, cortical shell from 140 to $600 \mu \mathrm{m}$ in diameter. Short radial spines emerging from nodal points of cortical shell. Presence of medullary shell suggested by inwardly directed struts from cortical shell." (Ormiston \& Lane 1976: 174).

\section{REMARKS}

Ormiston \& Lane (1976) noted that Lithocannosphaeropsis was erected by Deflandre without description and was thus a nomen nudum. They published a diagnosis in order to rectify that omission and to make the name available.

\section{Megaporus Feng in Feng, Meng, He \& Gu, 2006}

Megaporus Feng in Feng, Meng, He \& Gu, 2006c: S68.

Type species. - Megaporus jini Feng in Feng, Meng, He \& Gu, 2006 (Feng et al. 2006c: S68, pl. 1, fig. 1-19, pl. 1, 3, 8-9, 12).

AgE AND LOCATION OF TYPE MATERIAL. - Changhsingian, Upper Permian, Southern Guangxi, South China.

TAXON CODE. -297

STATUS. — Valid.

DiAGNOSIS. - "Test small, with two concentric shells: cortical and medullary shells. Cortical shell spherical, and composed of pentagonal and hexagonal pore frames with two to six three-bladed primary spines; pore frames thick and narrow; pores very large. Medullary shell small, consisting of pentagonal, hexagonal and irregular pore frames, and connected with cortical shell by some three-bladed and cylindrical beams. There is an initial spicule inside the medullary shell, and the spicule is relatively strong compared to the small medullary shell." (Feng in Feng et al. 2006c: S68).

\section{REMARKS}

The probable initial spicule mentioned is not visible in any of the published figures.

\section{Novormistonia Özdikmen, 2009}

Novormistonia Özdikmen, 2009: 246 (nomen novum for Ormis tonella $\mathrm{Li}, 1994$ ).

TYPe SPECIES. - Ormistonia pteracaena Li, 1991 (Li 1991: 75, nomen nudum); Li 1994: 271, pl. 2, fig. 19.

Age and location of TyPe Material. — Middle Silurian, Keerhada, Xinjiang western China.

TAXON CODE. - 298 .

STATUS. - Valid.

Diagnosis. - As for Ormistonia Li, 1994.

\section{Ormistonia Li, 1994}

Ormistonia Li, 1994: 270.

TyPE SPECIES. — Ormistonia pteracaena Li, 1991: 75 (nomen nudum); Li, 1994: 271, pl. 2, fig. 19.

Age And location of type material. — Middle Silurian, Keerhada, Xinjiang western China.

TAXON CODE. -299 .

STATUS. - Homonym; replacement name Novormistonia Özdikmen, 2009.

DIAGNOSIS. - "Test composed of four to six rays originating from a point, with two rays opposite in one axial direction, and the other 2-4 rays not perpendicular axially. Branches arising at two levels along each ray and generally forming an incomplete spongy shell at the first branch."

\section{REMARKS}

Both specimens figured, the holotype and paratype are fragmented and poorly preserved and badly imaged, so that it is difficult to see what is being figured, however the description indicates an inner spicule it is possible this taxon is an entactinarian. A trilobite genus described by Maksimova (1978) bears the same name.

\section{Palaeoactinosphaera Noble, 1994}

Palaeoactinosphaera Noble, 1994: 33.

TyPe SPECIES. - Palaeoactinosphaera antica Noble, 1994 (Noble 1994: 34, pl. 4, fig. 15-17).

AgE AND LOCATION OF TYPE MATERIAL. - Silurian, zones 1 though 5 of Noble (1994), East Bourland Mountain, Marathon uplift, west Texas, USA.

TAXON CODE. - 300 .

STATUS. - Valid.

DiAGNOSIS. - "Spherical to subspherical latticed cortical shell with six to eight primary spines and no secondary spines. Primary spines may be rod-shaped, grooved, or bladed, and can be arranged either perpendicular (orthogonally) or non-perpendicular (eccentrically) to each other. Primary bars extend inward and connect the cortical shell to the medullary shell. Primary bars are rod-shaped or three-bladed. Pore frames on cortical shell are polygonal to subcircular in outline and vary in their degree of regularity. Short nodes always occur at the juncture of pore frames, but are sometimes not well-preserved. Medullary shell may be either spherical or subspherical." (Noble 1994: 33).

\section{Praespongocoelia Noble, 1994}

Praespongocoelia Noble, 1994: 38.

TYPE SPECIES. - Spongocoelia parvus Furutani, 1990 (Furutani 1990: 47, pl. 9, fig. 6-7, pl. 10, fig. 1).

Age and location of type Material. - Upper Ludlow or Pridoli (Silurian), Horizon O-5, Osobudani Valley, Fukuji area, Gifu Prefecture, Japan. 
TAXON CODE. - 301

STATUS. - Valid.

DiAGNOSIS. - "Large robust subspherical to ovate shell with two robust bipolar spines. Spines are fat, wide, blunt-ended, and of unequal length. Base of spines have collar grooves and are slightly constricted at base. Shell consists of a single thickened layer of spongy cortical shell approximately 15 microns thick. Cortical shell may be ornamented with short hispid projections. Interior of shell is hollow; no internal structure has been observed." (Noble 1994: 38).

\section{Protobiramus Won in Won \& Below, 1999}

Protobiramus Won in Won \& Below, 1999: 358.

TyPE SPECIES. - Protobiramus biaxialus Won in Won \& Below, 1999 (Won \& Below 1999: 360, pl. 9, fig. 1-5, pl. 10, fig. 11).

Age and location of type material. - Middle Cambrian, Georgina Basin, Queensland, Australia.

TAXON CODE. - 302 .

STATUS. - Valid.

DiAGNOSIS. - "A spherical shell consisting of repeatedly bifurcated branches of a four- to six(?)-rayed, point-centered spicule that is positioned eccentrically." (Won in Won \& Below 1999: 358).

Retientactinosphaera Afanasieva, 2011

Retientactinosphaera Afanasieva, 2011: 127.

TYPE SPECIES. - Retientactinosphaera magnifica Afanasieva, 2011 (Afanasieva 2011: 127, pl. 1, fig. 1-5).

AgE AND LOCATION Of TYPE MATERIAL. — Lower Famennian (Upper Devonian), Saremboi-Lekkeyaga Swell, Timan-Pechora Basin, Russia.

TAXON CODE. - 303 .

STATUS. — Valid.

DiAgnosis. - "Shell spherical, with two reticulate spheres and one three-bladed main spine with triangular-shaped basal section. Inner framework consisting of narrow spicule, six rays of which diverging from median bar. Internal sphere very large, from half to three-fourths of shell diameter. Internal sphere complicated by many conical spines, connecting inner and outer spheres and terminating on sphere surface into by-spines or thorns." (Afanasieva 2011: 127).

\section{Russirad Afanasieva, 2000c}

Russirad Afanasieva, 2000c: 35.

TYPE SPECIES. - Russirad kazintsovae Afanasieva, 2000 (Afanasieva 2000c: 35, pl. 28, fig. 1-11).

Age And location of type material. — Famennian?, TimanPechora Basin, Russian platform, Russia.

TAXON CODE. - 304 .

STATUS. — Valid.
DiAGNOSIS. - "Раковина сферическая с Авумя оболочками: внешней решетчатой и внутренней - пористой. Внутренний каркаспредставмен тонкой спикулой, шесть кучей которой расходятся от срединной балки. Продомжением кучей спикул, явмяются основные трехгранные иглы." (Afanasieva 2000с: 35).

Diagnosis (English translation). — "Test spherical with two shells: external latticed and internal - porous. The inner frame is represented by a thin spicule, with six rays that diverge from the median bar. External continuation of spicule rays, form the main three bladed spines."

\section{REMARKS}

With these characters and external structure, including polygonal shape and spine morphology shown in the holotype this genus is very similar to Polyedroentactinia except that it has two shells instead of one.

\section{Stylactinosphaera Noble, 1994}

Stylactinosphaera Noble, 1994: 36.

TyPE SPECIES. - Stylactinosphaera prima Noble, 1994 (Noble 1994: 36, pl. 4, fig. 18-19).

Age AND LOCATION Of TYPE MATERIAL. - Silurian, zone 1 and lower zone 2 of Noble (1994), Payne Hills, Marathon uplift, west Texas, USA.

TAXON CODE. -305 .

STATUS. — Valid.

DiAGNOSIS. - "Latticed medullary shell surrounded by thickened, spinose cortical shell with six to eight robust primary spines. Rodshaped primary bars extend from cortical shell to latticed, subrounded medullary shell. Primary spines are conical with shallow grooves and alternating ridges at proximal end. Grooves and alternating ridges partially extend up the length of the spine. The cortical shell is covered by numerous secondary spines ( 20 or more per hemisphere) that are less than $75 \%$ the size of the primary spines. Grooves and alternating ridges occur at proximal end of secondary spines and partially extend up the spine length." (Noble 1994: 36).

Trigonosphaera Feng in Feng, Gu, Jiang \& Jin, 2004

Trigonosphaera Feng in Feng, Gu, Jiang \& Jin, 2004: 137.

TyPe SPECIES. - Trigonosphaera calvata Feng in Feng, Gu, Jiang \& Jin, 2004 (Feng et al. 2004: 142, pl. 3, fig. 1-7, pl. 4, fig. 1).

Age And location of type Material. - Upper Changhsingian (uppermost Permian), Dongpan section, Dalong Formation, Southern China.

TAXON CODE. - 306 .

STATUS. - Valid.

DiAGNOSIS. - " "Test consists of a single round-triangular cortical shell, without medullary shell and internal spicule. The shell is composed of two spongy layers. The two layers are similar in thickness, but different in structure: the inner layer is comprised of large, irregular pore frames and the outer layer, of small, irregular pore frames. Numerous beams connect the two layers." (Feng in Feng et al. 2004: 137). 


\section{REMARK}

Some centrally directed remains of the inner layer seem to suggest that there existed a central structure that was later dissolved by fossilization.

\section{NOMINA DUBIA}

Taxa considered nomen nudum or nomen dubium are listed under their respective families, when family assignment was possible. For those taxa where family designation is not possible, we list them below.

\section{Carposphaeridium Chapman, 1923}

Carposphaeridium Chapman, 1923: 37.

TyPE SPECIES. - Carposphaeridium cambrense Chapman, 1923 (Chapman 1923: 37, pl. 12, fig. 1).

Age and location of type material. - Upper Cambrian, Phosphate Hill mine, Loyola, Mansfield, Victoria, Australia.

TAXON CODE. - 307 .

STATUS. - Nomen dubium.

DiAGNOSIS. - "Wall of outer sphere rather thick, with a fairly coarse cancellation, surface dentate. Medullary sphere less than half the diameter of the cortical sphere and bearing short spikes; connected by numerous slender bars to the outer sphere. Medullary sphere with very fine cancellation" (Chapman 1923: 37).

\section{REMARK}

It is not possible to determine the nature of this radiolarian from the figured specimen.

\section{Diploplegma Hinde, 1890}

Diploplegma Hinde, 1890: 48.

TYPe SPECIES. - Diploplegma cinctum Hinde, 1890 (Hinde 1890: 48, pl. 3, fig. 10).

AgE AND LOCATION OF TYPE MATERIAL. - Upper Dapingian-Sandbian, Middle Ordovician from cherts in the Southern Uplands, Scotland.

TAXON CODE. - 308 .

STATUS. - Nomen dubium.

DiAgNOSIS. - "Liosphaerida with a relatively large inner (cortical?) test of irregularly reticulate or spongy framework and an outer shell of the same structure, the two connected by radial bars. In this genus the inner test is sufficiently large to be regarded as an inner cortical shell, and in this respect it resembles Liosphaera, Haeckel ('Challenger' Report, pt. i. p. 76), which has two cortical shells. It differs from Liosphaera, however, in the irregularly reticulate or spongy nature of tests." (Hinde 1890: 48).

\section{REMARK}

It is not possible to determine the nature of this radiolarian from the figured specimen.
Dorydictyum Hinde, 1890

Dorydictyum Hinde, 1890: 54.

TyPe SPeCIES. - Dorydictyum simplex Hinde, 1890 (Hinde 1890: 54, pl. 3, fig. 7).

AgE AND LOCATION OF TYPE MATERIAL. - Upper Dapingian-Sandbian, Middle Ordovician from cherts in the Southern Uplands, Scotland.

TAXON CODE. - 309.

STATUS. - Nomen dubium.

DiAGNOSIS. - "Sphaeroidea with tests of irregularly reticulate or spongy framework and a simple radial spine, with or without secondary spines. The structure of the test corresponds with that of Styptosphaera, Haeckel, and it differs from this genus by the addition of a radial spine. It is distinguished from Doryplegma by the absence of a medullary test." (Hinde 1890: 54).

\section{REMARK}

It is not possible to determine the nature of this radiolarian from the figured specimen.

\section{Doryplegma Hinde, 1890}

Doryplegma Hinde, 1890: 53.

TYPe SPECIES. - Doryplegma nasutum Hinde, 1890 (Hinde 1890: 53, pl. 3, fig. 9).

AgE AND LOCATION OF TYPE MATERIAL. - Upper Dapingian-Sandbian, Middle Ordovician from cherts in the Southern Uplands, Scotland.

TAXON CODE. - 310 .

STATUS. - Nomen dubium.

DiAgNOSIS. - "Sphaeroidea with cortical shells of irregularly reticulate or spongy framework, inclosing a central medullary shell and with a single primary radial spine. Secondary or smaller spines occasionally present. The structure of the shell in this genus is the same as in Spongoplegma, Haeckel, but with the addition of a radial spine and sometimes of secondary spines. From Dorysphaera it is distinguished by the different character of the framework and the presence of a medullary shell." (Hinde 1890: 53).

\section{REMARK}

It is not possible to determine the nature of this radiolarian from the figured specimen.

\section{Dorysphaera Hinde, 1890}

Dorysphaera Hinde, 1890: 52.

TyPe SPECIES. - Dorysphaera reticulata Hinde, 1890 (Hinde 1890: 52, pl. 3, fig. 3; pl. 4, fig. 3, holotype not designated).

AgE AND LOCATION OF TYPE MATERIAL. - Upper Dapingian-Sandbian, Middle Ordovician from cherts in the Southern Uplands, Scotland.

TAXON CODE. - 311 .

STATUS. - Nomen dubium. 
DiAGNOSIs. - " "Sphaeroidea with simple spherical lattice-shells and a single radial spine extending from the surface of the test. No medullary test." (Hinde 1890: 52).

\section{REMARK}

It is not possible to determine the nature of this radiolarian from the figured specimen.

\section{Duplexia Won, 1983}

Duplexia Won, 1983: 141.

TYPE SPECIES. - Entactinosphaera foremanae Ormiston \& Lane, 1976 (Ormiston \& Lane 1976: 166, pl. 1, fig. 9).

AgE AND LOCATION OF TYPE MATERIAL. - Upper Tournaisian to lower Visean, Sycamore Limestone Limestone, Arbuckle Mountains, Oklahoma, USA.

TAXON CODE. -312 .

STATUS. - Nomen dubium.

DiAGNOSIS. - "Das Skelett besteht aus einer doppelschichtigen sphäroidalen Außen- und einer ebenfalls sphäroidalen lnnenschale. Außere und innere Schicht der Außenschale liegen eng aneinander und zeigen die gleiche Gitterwerkstruktur wie die Innenschale. Die Stachelzahl variiert." (Won 1983: 141).

DiAGNOSIS (English translation by J. P. Caulet - RadWorld database). - "Test composed of a twice-layered spherical cortical shell and one equally spherical medullary shell. The outer and inner layers of the cortical shell are so closely distributed that the external meshwork looks like the inner shell. Number of spines variable."

\section{REMARKS}

There is no good reason to establish a new genus based on a taxon (Entactinosphaera foremanae Ormiston \& Lane, 1976), which clearly lies within the definition of the genus Trilonche (the senior synonym of Entactinosphaera).

\section{Ectoactinia Liu, 1992}

Ectoactinia Liu, 1992: 129.

TYPe SPECIES. - Ectoactinia tulufanensis Liu, 1992 (Liu 1992: pl. 1, fig. 1, 2).

AgE AND LOCATION OF TYPE MATERIAL. - Middle Carboniferous, east Tianshan Mountain, Xinjiang, China.

TAXON CODE. -313 .

STATUS. - Nomen dubium.

Diagnosis. - "Cortical test irregular spherical or subspherical latticed shell, with two radial spines, radiate from the surface of the shell, no medullary shell. there are the nipples and by-spines." (Liu 1992: 129).

\section{REMARK}

It is not possible to determine the nature of this radiolarian from the figured specimen.
Ehrenbergia Li, 1995

Ehrenbergia Li, 1995: 335.

TYPE SPECIES. - Ehrenbergia baijingensis Li, 1995 (Li 1995: 335, pl. 1, fig. 10).

Age AND location of TYPE MATERial. - Middle Ordovician: Darriwilian, the Baijingsi area in Qinghai Province.

TAXON CODE. -314

STATUS. - Nomen dubium.

DiAGNOSIS. - "Test as with Family (campanulate, without apical horn and aperture). Shell is small, campanulate, single. Whole shell covered by linearly arranged continuous costae. Pores distributed in single row between costae, pores is small. Bottom of shell with a hollow cave." (Li 1995: 335).

\section{REMARK}

It is not possible to determine the nature of this radiolarian from the figured specimen.

\section{Guangxitrisphaera Wang in Wang \& Kuang, 1993}

Guangxitrisphaera Wang in Wang \& Kuang, 1993: 285.

TYPE SPECIES. - Guangxitrisphaera wanyaoensis Wang in Wang \& Kuang, 1993 (Wang \& Kuang 1993: 285, pl. 3, fig. 15).

AgE AND LOCATION OF TYPE MATERIAL. - Lower Carboniferous, Visean, southeastern Guangxi, China.

TAXON CODE. -315 .

STATUS. - Nomen dubium.

DiAGNOSIS. - "Shell small, spherical, with three shells; inner and outer shells latticed, median shell in casting mould. Main spines over ten on shell surface; by-spines developed." (Wang in Wang \& Kuang 1993: 285).

\section{REMARK}

It is not possible to determine the nature of this radiolarian from the figured specimen.

\section{Gustefana Kozur, 1993}

Gustefana Kozur, 1993: 111.

TyPe sPECIES. - Gustefana obliqueannulata Kozur, 1993 (Kozur 1993: 111, pl. 3, fig. 1).

Age and location of type material. - Upper Permian of Western Sicily.

TAXON CODE. -316 .

STATUS. - Nomen dubium.

DiAGNOSIS. - "Test large, slender conical to cylindrical. Pore frames consisting of oblique rings and often indistinct vertical ridges." (Kozur 1993: 111). 


\section{REMARKS}

It is not possible to determine the nature of this radiolarian from the figured specimen. Possibly an aberrant representative of the Ruzhencevispongus Kozur, 1980 with only one arm.

\section{Induropilarius Ters \& Deflandre, 1966}

Induropilarius Ters \& Deflandre, 1966: 340.

TyPe SPECIES. — Induropilarius aenigmaticus Ters \& Deflandre, 1966 (Ters \& Deflandre 1966: 340, figs 10-12, holotype not designed).

AGE AND LOCATION OF TYPE MATERIAL. - Cambrian-Silurian ancient land of Vendée coast (former Brioverian).

TAXON CODE. - 317 .

STATUS. - Nomen dubium.

DiAGNOSIS. - "Sphères silico-organiques peu déformables; membrane épaisse, brunaâtre; structure fibroradiée périphérique ou totale." (Ters \& Deflandre 1966: 340).

\section{REMARK}

It is not possible to determine the nature of this radiolarian from the figured specimen.

\section{Palaeolithochytris Li, 1995}

Palaeolithochytris Li, 1995: 336.

TYPE SPECIES. - Palaeolithochytris olenus Li, 1995 (Li 1995: 336 , pl. 1, fig. 9).

AgE AND LOCATION OF TYPE MATERIAL. - Ordovician: Darriwilian so far as is known, the Baijingsi area in Qinghai Province.

TAXON CODE. - 318 .

STATUS. — Nomen dubium.

DiAGNOSIS. - "Test is pyramid in outline, cephalis is subspherical without apical horn, with three-four feet, the surface of shell with pores and grooves." (Li 1995: 336).

\section{REMARK}

It is not possible to determine the nature of this radiolarian from the figured specimen.

\section{Palamphimorphium Ters \& Deflandre, 1966}

Palamphimorphium Ters \& Deflandre, 1966: 340.

TYPE SPECIES. - Palamphimorphium speciosum Ters \& Deflandre, 1966 (Ters \& Deflandre 1966: 340, fig. 13).

AgE AND LOCATION OF TYPE MATERIAL. - Cambrian-Silurian ancient land of Vendée coast (former Brioverian).

TAXON CODE. -319

STATUS. - Nomen dubium.
DiAgnosis. - Microorganisme à double constitution: masse centrale sllico-organique à membrane noirâtre, arrondie ou mamelonnée, contenant des sphérules délicatement structurées (parfois indiscernables), enveloppée par une masse translucide quartzifiée oblongue, ou fuselée, allongée. (Ters \& Deflandre 1966: 340).

Diagnosis (ENGLiSH TRANSLATION). - Microorganism with a double construction: central mass with organic-siliceous blackish membrane, rounded or mamillated, containing delicately structured spherules (sometimes not discernible), enveloped by an elongated translucent quartz mass that is oblong or fusiform.

\section{REMARK}

It is not possible to determine the nature of this radiolarian from the figured specimen.

\section{Paleocenosphaera Nazarov, 1973}

Paleocenosphaera Nazarov, 1973: 8.

TyPe SPECIES. - Paleocenosphaera magna Nazarov, 1973 (Nazarov 1973: 8, pl. 1, fig. 1; pl. 2, fig. 2); Nazarov 1975b: pl. 8, fig. 14.

Age AND location of tYPE MATERIAL. - Lower Cambrian Atdabanskij Stage Kuznetskij Alatau Batenevskij ridge, $3 \mathrm{~km}$ to the north of Bograd village, Siberia.

TAXON CODE. -320 .

STATUS. - Nomen dubium.

DiagNOSIS (English translation of Nazarov [1975b] by E. Roden - in the rad database microfiche collection of Bill Riedel). "The small shell is irregularly spherical in outline and has short outer spines. The short conical spines which are tapered at the distal end, are best expressed around the pores. Thin outer shell of the skeleton with irregularly distributed angularly oval, more rarely hexagonal pores. To judge from sections, the inner spine was centrally located. Because of the poor preservation of the material at hand, the number of its rays is hard to establish, but obviously there were not more than ten." (translated from Nazarov 1973: 8).

REMARKS

It is not possible to determine the nature of this radiolarian from the figured specimen. However, Nazarov (1975b) reassigns the type specimen to Polyentactinia Foreman, 1963.

\section{Palhindeolithus Deflandre, 1973}

Palhindeolithus Deflandre, 1973a: 498.

Type SPECIES. - Palhindeolithus ambiguus Deflandre, 1973 (Deflandre 1973a: 292, pl. 1, fig. 4).

AgE AND LOCATION OF TYPE MATERIAL. - Visean France.

TAXON CODE. - 321 .

STATUS. - Nomen dubium.

DiAGNOSIS. - "Spicule siliceux à bâtonnet médian, portant à chaque extrémité $\mathrm{n}$ branches ou actines cylindriques, simples ou ornées de cornes ou d'épines." (Deflandre 1973a: 498). 
Diagnosis (English translation by J. P. Caulet - RadWorld database). - "Siliceous spicule with a median bar carrying at both ends n branches or spicules cylindrical, simple or with horns or spines."

\section{REMARK}

It is not possible to determine the nature of this radiolarian from the figured specimen.

\section{Papinochium Ters \& Deflandre, 1966}

Papinochium Ters \& Deflandre, 1966: 340.

Type sPeCies. - Papinochium dubium Ters \& Deflandre, 1966 (Ters \& Deflandre 1966: 340, fig. 15).

AgE AND LOCATION OF TYPE MATERIAL. - Cambrian-Silurian ancient land of Vendée coast (former Brioverian).

TAXON CODE. -322

STATUS. - Nomen dubium.

DiAGNOSIS. - Micro-organisme apparemment sphétoidal, muni d'appendices creux, mousses; déformable (Ters \& Deflandre 1966 fig. 15), parfois désagrégé; souvent fossilisé en chlorite fibreuse verdâtre.

ENGLiSH TRANSLATION. - Microorganism apparently spheroidal with hollow spongy deformed appendages.

\section{REMARK}

It is not possible to determine the nature of this radiolarian from the figured specimen.

\section{Primaritripus Afanasieva, 2000}

Primaritripus Afanasieva, 2000c: 92.

TYPE SPECIES. - Spongotripus patella Hinde, 1899 (Hinde 1899a: 55, pl. 9, fig. 21).

Age And location of tyPe Material. — Middle Devonian, Givetian, NSW, eastern Australia.

TAXON CODE. - 323 .

STATUS. - Nomen dubium.

DIAGNOSIS. - "Раковина дисковидная или субтреугольная с одной губчатой оболочкой. СтроеЮіе внутреннего каркаса не ясно. Три массивные основные иглы расположены в экваториальной части раковины и иногда обрастают губчатой ІКанъю внешней оболочки скемета". (Afanasieva 2000c: 92).

ENGLISH TRANSLATION. - " "Test discoidal or subtriangular, with one porous or spongy shell. Structure of internal framework uncertain. From two to four main spines located in equatorial part of shell, occasionally with apophyses and sometimes enveloped by porous tissue of external shell. Two polar spines very short, frequently absent. Additional spines absent, external ornament sometimes represented by spinules." (Afanasieva \& Amon 2008: 464).

\section{REMARKS}

Hinde's (1899a) original description suggested that the specimen he figured on plate IX, fig. 21 is discoidal. However, it is impossible to ascertain whether this might be an original feature or the result of sediment compaction. Original specimens of the species that Afanasieva (2000c) nominated as type for Primatipus were re-examined by Aitchison \& Stratford (1997) and considering the state of preservation of the single specimen they re-assigned it in open nomenclature to ?Spongentactinia. It is simply not possible to determine the nature of this radiolarian from the figured specimen. As such it is not suitable as a type specimen and Primaritripus, must be regarded as nomen dubium.

Protosegmentum Wang in Wang, Cheng \& Zhang, 2008 Protosegmentum Wang in Wang, Cheng \& Zhang, 2008: 401.

TYPe SPECIES. - Protosegmentum xinjiangensis Wang in Wang, Cheng \& Zhang, 2008 (Wang et al. 2008: 401, pl. 2, figs 6-9, 14).

Age and location of TyPe material. - Middle Ordovician Dapingian, Tarim Basin, Xinjiang, China.

TAXON CODE. - 324 .

STATUS. - Nomen dubium.

DESCRIPTION. - "Shell long cylindric, composed of cephalous, thoraxinal and abdominal chambers. The abdominal chamber consists of the ring and the furrow interval and there are some pores on the ring." (Wang in Wang et al. 2008: 401).

\section{REMARK}

It is not possible to determine the nature of this radiolarian from the figured specimen.

Pseudostigmosphaera Kozur \& Mostler, 1979

Pseudostigmosphaera Kozur \& Mostler, 1979: 30.

TyPE SPECIES. - Stigmosphaera mira Rüst, 1892 (Rüst 1892: 135, pl. 6, fig. 11).

Age AND LOCATION OF TYPE MATERIAL. — Lower Carboniferous, Germany.

TAXON CODE. -325

STATUS. - Nomen dubium.

DiAGNOSIS. — "Centrolonchinae mit 6 oder mehr kräftigen inneren Stacheln, die sich in einem Punkt oder in einem kurzen Balken treffen, aber nicht über die einfache Gitterschale nach außen reichen." (Kozur \& Mostler 1979: 30).

\section{REMARK}

It is not possible to determine the nature of this radiolarian from the figured specimen and the type material is unavailable.

\section{Spongocoelia Hinde, 1899}

Spongocoelia Hinde, 1899a: 52. 
TYPE SPECIES. - Spongocoelia citreum Hinde, 1899 (Hinde 1899a: 52, pl. 9, fig. 18)

Age AND LOCATION OF TYPE MATERIAL. - Middle Devonian, Givetian, NSW, eastern Australia.

TAXON CODE. - 326 .

STATUS. - Nomen dubium.

DiAgNOSIS. - "The test is ellipsoidal, with an irregularly reticulate or spongy framework and central cavity, without medullary shell. There are two opposite radial spines, and within the test slender rods similar to those in Stigmosphaera, Haeckel, or a central spicular body." (Hinde 1899a: 52).

\section{REMARK}

It is not possible to determine the internal nature of this radiolarian from the figured specimen.

\section{Srakaeosphaera Sashida in Sashida, Adachi, Igo,} Nakornski \& Ampornmaha, 1997

Srakaeosphaera Sashida in Sashida, Adachi, Igo, Nakornski \& Ampornmaha, 1997: 12.

TYPE SPECIES. — Srakaeosphaera minuta Sashida in Sashida, Adachi, Igo, Nakornski \& Ampornmaha, 1997 (Sashida et al. 1997: 12, fig. 6.3).

Age and location of type material. - Upper Middle Permian to lower Upper Permian (Murgabian to Midian), eastern Thailand.

TAXON CODE. - 327.

STATUS. - Nomen dubium.

DIAGNOSIS. - "Small spherical shell with six to nine concentric spheres. Outermost sphere bears no spines." (Sashida in Sashida et al. 1997: 12).

\section{REMARK}

It is not possible to determine the nature of this radiolarian from the figured specimen.

\section{Stauroplegma Hinde, 1890}

Stauroplegma Hinde, 1890: 49

TYPE SPECIES. - Stauroplegma brevispina Hinde, 1890 (Hinde 1890: 50, pl. 4, fig. 5)

AgE AND LOCATION OF TYPE MATERIAL. — Upper Dapingian-Sandbian, Middle Ordovician from cherts in the Southern Uplands, Scotland.

TAXON CODE. - 328 .

STATUS. - Nomen dubium.

DIAGNOSIS. - "Staurosphaerida with solid, irregularly reticulate or spongy shell, a concentric medullary shell, and four simple spines approximately in the form of a cross. This genus differs from Staurodoras by the possession of an inner medullary test." (Hinde 1890: 49).

\section{REMARK}

It is not possible to determine the nature of this radiolarian from the figured specimen.
Tetrasphaera Wang in Wang, Cheng \& Zhang, 2008

Tetrasphaera Wang in Wang, Cheng \& Zhang, 2008: 401.

TYPE SPECIES. - Tetrasphaera kuruktagensis Wang in Wang, Cheng \& Zhang, 2008 (Wang et al. 2008: 401, pl. II, figs 10-13).

Age and location of type Material. - Middle Ordovician Dapingian, Tarim Basin, Xinjiang, China.

TAXON CODE. - 329 .

STATUS. - Nomen dubium.

DiAGNOSIS. - "Shell spherical, composed of four concentric latticed test, one outer and three medullary ones. Every test is connected by radial beams. The distance within every test is the same. Not any spines and by-spines on shell body are found." (Wang in Wang et al. 2008: 401).

REMARK

It is not possible to determine the nature of this radiolarian from the figured specimen.

\section{Triposphaera Hinde, 1890}

Triposphaera Hinde, 1890: 54.

TyPE SPECIES. - Triposphaera peachii Hinde, 1890 (Hinde 1890: 55, pl. 4, fig. 9).

AgE AND LOCATION OF TYPE MATERIAL. - Upper Dapingian-Sandbian, Middle Ordovician from cherts in the Southern Uplands, Scotland.

TAXON CODE. - 330 .

STATUS. - Nomen dubium.

DiAGNOSIS. - "Sphaeroidea with an irregularly reticulate or spongy framework, a medullary shell, and three primary radial spines. Smaller secondary spines occasionally present." (Hinde 1890: 54).

\section{REMARK}

It is not possible to determine the nature of this radiolarian from the figured specimen.

\section{Ulcundia Nazarov, 1974}

Ulcundia Nazarov, 1974: 110.

TYPE SPECIES. - Ulcundia incomperta Nazarov, 1974 (Nazarov 1974: 111, pl. 2, fig. 5).

AgE AND LOCATION OF TYPE MATERIAL. - Floian-Darriwilian, LowerMiddle Ordovician, northeast of Central Kazakhstan, Lake Sasykaor.

TAXON CODE. - 331 .

STATUS. - Nomen dubium.

DiAgNOSIS (English translation of Nazarov [1975b] by E. Roden - in the rad database microfiche collection of Bill Riedel). - "Rounded, oval, triangular-rounded forms with one or two siliceous, spongy or 'porous' shells, which occur in single specimens as well as in aggregations of several tens or hundreds of specimens." (Nazarov 1974: 110). 


\section{REMARK}

It is not possible to determine the nature of this radiolarian from the figured specimen.

\section{Wangia Feng \& Liu, 1993}

Wangia Feng \& Liu, 1993b: 544.

Type SPECIES. - Wangia biturbinata Feng \& Liu, 1993 (Feng \& Liu 1993b: 544, pl. 1, fig. 18).

Age AND location of TYPE MATERIAL. - Upper Permian, southwest Yunnan, China.

TAXON CODE. - 332 .

STATUS. - Nomen dubium.

DiAGNOSIS. 一壳呈双凸透镜状, 格子状或海绵状壳; 两根主刺, 相对而生' 棒状或仅基部有短的凹槽 (Feng \& Liu 1993b: 544).

Diagnosis (ENGLiSH TRANSLATION). — Shell is lenticular, grid-like or sponge-like; two main rodded spines at the base of which there is a short groove.

\section{REMARK}

It is not possible to determine the nature of this radiolarian from the figured specimen.

\section{Palaeodiscaleksus Afanasieva, 2008}

Palaeodiscaleksus Afanasieva, 2008: 101.

TYPE SPECIES. - Spongodiscus punctus Hinde, 1899 (Hinde 1899a: 54, pl. 9, fig. 14).

Age AND location of type Material. — Middle Devonian, Givetian, NSW, eastern Australia.

TAXON CODE. - 333

STATUS. — Nomen dubium.

\section{REMARKS}

Replacement name for the preoccupied name Palaeodiscus introduced by Afanasieva (2000c). Palaeodiscus is nomen dubium (see below).

\section{Palaeodiscus Afanasieva, 2000}

Palaeodiscus Afanasieva, 2000c: 91.

TYPE SPECIES. - Spongodiscus punctus Hinde, 1899 (Hinde 1899a, p. 54, pl. 9, fig. 14).

Age AND location of type Material. — Middle Devonian, Givetian, NSW, eastern Australia.

TAXON CODE. - 334 .

STATUS. - Nomen dubium.

DIAGNOSIS. — "Раковина дисковидная с одной губчатой оболочкой. Строение внутреннего каркаса не ясно. Основные иглы очень короткие, но обычно отсутствуют." (Afanasieva 2000с: 91).
Diagnosis (English translation). - “Test discoidal, with one spongy or porous shell. Structure of internal framework uncertain. Main spines absent, but short subsidiary spines occasionally present." (Afanasieva \& Amon 2008: 462)

\section{REMARK}

It is not possible to resolve the nature of the type material figured by Hinde (1899a).

\section{NOT RADIOLARIA}

Those taxa published as radiolarians, but determined to be some other fossil groups are listed below:

Anakrusa Nazarov, 1977

Anakrusa Nazarov, 1977: 38

TYPE SPECIES. - Anakrusa miriacantha Nazarov, 1977 (Nazarov 1977: 38, pl. 1, fig. 1).

AgE AND LOCATION OF TYPE MATERIAL. - Upper Dapingian-lower Sandbian, Middle Ordovician, Bestamakian suite, southwestern foothills of the Chingiz range, Chagan River, Kazakhstan.

TAXON CODE. - 335 .

REMARKS

This genus is a sponge sclerite. See Won et al. (2007b).

\section{Auliela Nazarov, 1977}

Auliela Nazarov, 1977: 39.

TyPe SPECIES. - Auliela aspersa Nazarov, 1977 (Nazarov 1977: 40 pl. 1, figs 4-6; holotype never figured, only paratype).

AgE AND LOCATION OF TYPE MATERIAL. - Upper Dapingian-Sandbian, Middle Ordovician, Bestamakian suite, southwestern foothills of the Chingiz range, Chagan River, Kazakhstan.

TAXON CODE. -336 .

\section{REMARKS}

This genus is a sponge sclerite. See De Wever et al. (2001).

\section{Azyrtalia Nazarov, 1973}

Azyrtalia Nazarov, 1973: 11

TYPe SPECIES. - Azyrtalia dilata Nazarov, 1973 (Nazarov 1973: 12, pl. 1, figs 9-11).

AgE AND LOCATION OF TYPE MATERIAL. — Lower Cambrian, Kazakhstan.

TAXON CODE. -337 .

REMARKS

This genus is recognized and treated as a sponge spicule by Bengtson (1986) and Kozur et al. (1996). It is likely to rep- 
resent the senior synonym of the sponge spicule genus Rigbyella Mostler \& Mosleh-Yazdi (1976) - see Elicki (2011) for discussion.

\section{Batoballa Wang, Cheng \& Zhang, 2008}

Batoballa Wang, Cheng \& Zhang, 2008: 396.

Type sPeCies. - Batoballa communis Wang in Wang, Cheng \& Zhang, 2008 (Wang et al. 2008: 396, pl. 2, fig. 2).

Age ANd location OF tYpe MATERial. - Middle Ordovician Dapingian, Tarim Basin, Xinjiang, China.

TAXON CODE. - 338 .

\section{REMARKS}

This genus is a sponge spicule and closely similar to Azytalia Nazarov, 1973.

\section{Eoconcharium Hao \& Shu, 1987}

Eoconcharium Hao \& Shu, 1987: 308.

TYPE SPECIES. - Eoconcharium chinense Hao \& Shu, 1987 (Hao \& Shu 1987: 309, pl. 1, fig. 3a).

Age AND location of type MATERial. — Lower Cambrian (Adtabanian, Eoredlichia Zone) Shuijingtuo Formation, Zhenba, Shaanxi Province, China.

TAXON CODE. - 339 .

REMARK

Identified as plates of the lobopodian Microdictyon (see Zhang \& Aldridge 2007).

Fusuconcharium Hao \& Shu, 1987

Fusuconcharium Hao \& Shu, 1987: 309.

TYPE SPECIES. - Fusuconcharium typicum Hao \& Shu, 1987 (Hao \& Shu 1987: 309, pl. 4, figs 1-2).

AgE AND LOCATION OF TYPE MATERIAL. - Lower Cambrian (Adtabanian, Eoredlichia Zone) Shuijingtuo Formation, Zhenba, Shaanxi Province, China.

TAXON CODE. - 340 .

REMARK

Identified as plates of the lobopodian Microdictyon (see Zhang \& Aldridge 2007)

\section{Konyrium Nazarov \& Popov, 1976}

Konyrium Nazarov \& Popov, 1976: 41.

TYPe SPECIES. - Konyrium varium Nazarov \& Popov, 1976 (Nazarov \& Popov 1976: 41, pl. 3, fig. 19).
Age and location of type Material. - Upper Cambrian, Kazakhstan.

TAXON CODE. - 341 .

REMARK

This genus is recognized and treated as a hexatinellid sponge spicule by Bengtson (1986).

\section{Lacisus Kozur, 1993}

Lacisus Kozur, 1993: 109.

TYPE SPECIES. - Lacisus siphunculus Kozur, 1993 (Kozur 1993: 109, pl. 1, fig. 12).

Age and location of type material. - Dzhulfian Upper Permian of the Sosio Valley area, Western Sicily.

TAXON CODE. -342 .

REMARK

The material figured does not convincingly belong to the radiolarians.

Palaeorubus Ishiga in Ishiga, Leitch, Naka, Watanabe \& Iwasaki, 1987

Palaeorubus Ishiga in Ishiga, Leitch, Naka, Watanabe \& Iwasaki, 1987: 300 .

TYPE SPECIES. - Palaeorubus hastingensis Ishiga in Ishiga, Leitch, Naka, Watanabe \& Iwasaki, 1987 (Ishiga et al. 1987: 300, pl. 2, fig. 8).

Age and location of type material. - Upper Devonian, New England Fold Belt, eastern Australia.

TAXON CODE. -343 .

REMARKS

This morphotype is a widely distributed sponge spicule that is common in residues recovered from processing of Devonian and Carboniferous chert samples - see Aitchison (1989).

\section{Quadratapora Hao \& Shu, 1987}

Quadratapora Hao \& Shu, 1987: 309.

TYPE SPECIES. - Quadratapora zhenbaensis Hao \& Shu, 1987 (Hao \& Shu 1987: 309, pl. 4, fig. 4a).

Age AND LOCATION OF TYPE MATERIAL. - Lower Cambrian (Adtabanian, Eoredlichia Zone) Shuijingtuo Formation, Zhenba, Shaanxi Province, China.

TAXON CODE. -344 .

REMARK

Identified as plates of the lobopodian Microdictyon (see Zhang \& Aldridge, 2007). 


\section{Acknowledgements}

We thank A. Kolesnikov for help with Russian translations, reviewers $\mathrm{O}$. Obut and F. Cordey for their helpful comments and review of some of the foreign language text. JA acknowledges financial support towards the investigation of Paleozoic radiolarian evolution in the form of a grant from the Australian Research Council (ARC DP 1501013325), and PN acknowledges support from University of Nevada Reno International Activities Grant.

\section{REFERENCES}

AfanasieVA M. S. 1986. - Radiolarians of the family Pylentonemidae. Paleontological Journal 3: 22-34.

AFANASIEVA M. S. 1997. - Biostratigraphic significance of some early Frasnian radiolarians. Doklady Akademii Nauk 355 (2): 217-222.

AfANASIEVA M. S. 2000a. - New radiolarians of the orders Aculearia and Sphaerellaria from the Upper Devonian of the Timan-Pechora Province (Russia). Paleontological Journal 34 (4): 359-376.

AfANASIEVA M. S. 2000b. - New radiolarians of the superfamily Entactinoidea from the Upper Devonian of Timan-Pechora Province, Russia. Paleontological Journal 34 (2): 131-146.

Afanasieva M. S. 2000c. - Atlas of Paleozoic Radiolaria of the Russian Platform. Scientific World, Moscow, 477 p.

AfanasieVA M. S. 2008. - New replacement names for the Genus Palaeodiscus Afasanieva, 2000 and the Family Palaeodiscidae Afasanieva, 2000 (Radiolaria). Paleontological Journal 42 (4): 440. https://doi.org/10.1134/S003103010804014X

AfANASIEVA M. S. 2009. - New replacement names for the genera Adamas Afanasieva, 2000 and Wonella Afanasieva, 2000 (Radiolaria). Paleontological Journal 43 (1): 115. https://doi.org/10.1134/ S0031030109010122

AfANASIEVA M. S. 2011. - Revision of the genus Entactinosphaera Foreman 1963 and the new genus Retientactinosphaera gen. nov. (Paleozoic radiolaria). Paleontological Journal 45 (2): 117-129. https://doi.org/10.1134/S003103011102002X

AfANASIEVA M. S. \& MikHAilova M. V. 1998. - Radiolarians as one of the possible sources of the oil organic matter. Geology of Oil and Gas 1: 12-21.

AfanasieVA M. S. \& AmON E. O. 2008. - New Radiolarians from the Devonian of the Southern Ural Mountains: 1. Erly-Middle Devonian (Late Emsian-Early Eifelian). Paleontological Journal 42 (5): 451-467

AfANASIEVA M. S. \& AMON E. O. 2016. - New radiolarian genera and species from the Lower Permian of the Southern Urals and Northern Mugodzhary. Paleontological Journal 50 (3): 209-221. https://doi.org/10.1134/S0031030116020027

Afanasieva M. S., Amon E. O., Agarkov Y. V. \& Boltovskoy D. S. 2005. - Radiolarians in the geological record. Paleontological Journal 39 (suppl. 3): 135-392.

AITCHISON J. C. 1989. - Discussion: Radiolarian and conodont biostratigraphy of siliceous rocks from the New England Fold Belt. Australian Journal of Earth Sciences 36: 141-142. https:// doi.org/10.1080/14400958908527958

AitchisOn J. C. 1993a. - Albaillellaria from the New England orogen, Eastern NSW, Australia. Marine Micropaleontology 21: 353-367. https://doi.org/10.1016/0377-8398(93)90026-T

Aitchison J. C. 1993b. — Devonian (Frasnian) Radiolarians from the Gogo Formation, Canning Basin, Western Australia. Palaeontographica. Abteilung A: Palaozoologie-Stratigraphie 228: 105-128.

AITCHISON J. C. 1998. — A Lower Ordovician (Arenig) radiolarian fauna from the Ballantrae Complex, Scotland. Scottish Journal of Geology 34 (1): 73-81. https://doi.org/10.1144/sjg34010073

AitChison J. C. \& StratFord J. M. C. 1997. — Middle Devonian (Givetian) Radiolaria from eastern New South Wales, Australia; a reassessment of the Hinde (1899) fauna. Neues Jahrbuch für Geologie und Paläontologie, Abhandlungen 203 (3): 369-390.

Aitchison J. C., Flood P. G. \& Malpas J. 1998. — Lowermost Ordovician (basal Tremadoc) radiolarians from the Little Port Complex, western Newfoundland (Lower Ordovician radiolarians, Newfoundland). Geological Magazine 135: 413-419. https:// doi.org/10.1017/S001675689800867X

Aitchison J. C., Davis A. M., Stratford J. M. C. \& Spiller F. C. P. 1999. - Lower and Middle Devonian radiolarian biozonation of the Gamilaroi terrane New England Orogen, eastern Australia. Micropaleontology 45 (2): 138-162. https:// doi.org/10.2307/1486110

Aitchison J. C., Hada S., Ireland T. \& Yoshikura S. 1996. Ages of Silurian radiolarians from the Kurosegawa terrane, southwest Japan constrained by U/Pb SHRIMP data. Journal of Southeast Asian Earth Sciences 14: 53-70. https://doi.org/10.1016/ S0743-9547(96)00045-1

Amon E. O., Braun A. \& Ivanov K. S. 1995. - Upper Silurian radiolarians from the southern Urals. Geologica et Paleontologica 29: 1-18.

BENGTSON S. 1986. — Siliceous microfossils from the Upper Cambrian of Queensland. Alcheringa 10 (3): 195 - 216. https://doi. org/10.1080/03115518608619155

BIRINA L. M. 1948. - New species of calcareous algae and foraminifera from the Devonian-Carboniferous boundary. Sovetsk. Geol. Moscow 28: 159.

Boundy-Sanders S. Q., SAndberg C. A., Murchey B. L. \& HarRIS A. G. 1999. - A late Frasnian (Late Devonian) radiolarian, sponge spicule, and conodont fauna from the Slaven Chert, northern Shoshone Range, Roberts Mountains allochthon, Nevada. Micropaleontology 45 (1): 62-68. https://doi.org/10.2307/1486203

Caridroit M. \& De Wever P. 1984. — Description de quelques nouvelles espèces de Follicucullidae et d'Entactinidae (Radiolaires polycystines) du Permien du Japon. Geobios 17 (5): 639-644. https://doi.org/10.1016/S0016-6995(84)80035-2

Caridroit M. \& De Wever P. 1986. — Some late Permian radiolarians from pelitic rocks of the Tatsuno formation (Hyogo Prefecture), southwest Japan. Marine Micropaleontology 11: 55-90. https://doi.org/10.1016/0377-8398(86)90005-8

Caridroit M., De Wever P. \& Dumitrica P. 1999. — Un nouvel ordre, une nouvelle famille et un nouveau genre de Radiolaires du Paléozoïque: Latentifistularia, Cauletellidae et Cauletella. Comptes Rendus de l'Académie des Sciences de Paris, Série IIA Sciences de la Terre et des Planètes 329 (8): 603-608. https://doi. org/10.1016/S1251-8050(00)87217-1

Caridroit M., Danelian T., O’Dogherty L., Cuvelier J., Aitchison J. C., Pouille L., Noble P., Dumitrica P., SuZuki N., Kuwahara K., Maletz J. \& Feng Q. 2017. — An illustrated catalogue and revised classification of Paleozoic radiolarian genera, in Danelian T., Caridroit M., Noble P. \& Aitchison J. C. (eds), Catalogue of Paleozoic radiolarian genera. Geodiversitas 39 (3): 363-417. https://doi.org/10.5252/g2017n3a3

ChapMAN F. 1923. - Report on fossils from an Upper Cambrian horizon at Loyola, near Mansfield. Bulletin of the Geological Survey of Victoria 46: 34-45.

CHEng Y.-N. 1986. - Taxonomic Studies on Upper Paleozoic Radiolaria. National Museum of Natural Science, Taiwan, Special Publication, vol. 1, 310 p.

CORDEY F. 1998. - Radiolaires des complexes d'accrétion de la Cordillère Canadienne (Colombie-Britannique). Geological Survey of Canada, Bulletin 509: 1-209.

CORNELL W. C. \& Simpson R. D. 1986. - Nabespecha leonardia, n. gen., n. sp.: An unusual radiolarian from the Permian of West Texas. Micropaleontology 32 (3): 286-288. https://doi. org/10.2307/1485623

DANELIAN T. \& POPOV L. 2003. - Ordovician radiolarian biodiversity: insights based on new and revised data from Kazakhstan. Bulletin de la Société Géologique de France 174 (4): 325-335. https://doi.org/10.2113/174.4.325 
De Wever P. \& Caridroit M. 1984. — Description de quelques nouveaux Latentifistulidae (radiolaires polycystines) Paléozoïques du Japon. Revue de Micropaléontologie 27 (2): 98-106.

De Wever P., Dumitrica P., Caulet J. P., Nigrini C. \& Caridroit M. 2001. - Radiolarians in the Sedimentary Record. Gordon and Breach Science Publishers, Amsterdam, 533 p.

Deflandre G. 1952. - Albaillella nov. gen., radiolaire fossile du Carbonifère inférieur, type d'une lignée aberrante éteinte. Comptes Rendus hebdomadaires des Séances de l'Académie des Sciences (Paris), Série D: Sciences naturelles 234: 872-874. http:// gallica.bnf.fr/ark:/12148/bpt6k3186w

DefLANDRE G. 1953. — Radiolaires fossiles, in Grassé P. P. (ed.), Traité de Zoologie. Masson, Paris: 389-436.

DeFlandre G. 1958. - Lapidopiscum nov. gen., type nouveau de Radiolaire viséen, famille des Lapidopiscidae fam. nov., de l'ordre des Albaillellidae Defl. 1953. Comptes Rendus hebdomadaires des Séances de l'Académie des Sciences (Paris), Série D: Sciences naturelles 246: 2278-2280. http://gallica.bnf.fr/ark:/12148/bpt6k723q

DEFLANDRE G. 1960. - A propos du développement des recherches sur les Radiolaires fossiles. Revue de Micropaléontologie 2 (4): 212-218.

Deflandre G. 1963. - Pylentonema, nouveau genre de Radiolaire du Viséen: Sphaerellaire ou Nassellaire? Comptes Rendus hebdomadaires des Séances de l'Académie des Sciences (Paris), Série D: Sciences naturelles 257: 3981-3984. http://gallica.bnf.fr/ ark:/12148/bpt6k4009k

DeFlandre G. 1964. — La famille des Popofskyellidae fam. nov. et le genre Popofskyellum Defl., Radiolaires viséens de la Montagne Noire. Comptes Rendus hebdomadaires des Séances de l'Académie des Sciences (Paris), Série D: Sciences naturelles 259: 3055-3058. http://gallica.bnf.fr/ark:/12148/bpt6k4015m

DEFLANDRE G. 1972a. — Le système trabéculaire interne chez les Pylentonémidés et les Popofskyellidés, Radiolaires du Paleozoique. Phylogenèse des Nassellaires. Comptes Rendus hebdomadaires des Séances de l'Académie des Sciences (Paris), Série D: Sciences naturelles 274 (26): 3535-3540. http://gallica.bnf.fr/ark:/12148/ bpt6k5682741m

DEFLANDRE G. 1972b. - Remarques complémentaires sur la morphologie et la nomenclature de quelques genres de Radiolaires du Paléozoïque. Comptes Rendus hebdomadaires des Séances de l'Académie des Sciences (Paris), Série D: Sciences naturelles 275 (1): 13-16. http://gallica.bnf.fr/ark:/12148/bpt6k57786873

DEFLANDRE G. 1973a. - Sur quelques nouveaux types de radiolaires Polycystines viséens, d'attribution systématique ambiguë, certain évoquant à la fois des Plectellaires et des Spumellaires. Comptes Rendus hebdomadaires des Séances de l'Académie des Sciences (Paris), Série D: Sciences naturelles 276: 289-293. http://gallica.bnf.fr/ ark:/12148/bpt6k5803214k

DeFLANDRE G. 1973b. — Compléments historiques et taxinomiques sur les Radiolaires viséens. Remarques critiques sur les Plectellaires. Comptes Rendus hebdomadaires des Séances de l'Académie des Sciences (Paris), Série D: Sciences naturelles 276 (1): 497-500. http://gallica.bnf.fr/ark:/12148/bpt6k5803214k

DEFLANDRE G. 1973c. - Observations et remarques sur les Radiolaires Sphaerellaires du Paléozoïque, à propos d'une nouvelle espece, viséenne, du genre Foremaniella Defl., parfait intermediaire entre les Périaxoplastidiés et les Pylentonémidés. Comptes Rendus hebdomadaires des Séances de l'Académie des Sciences (Paris), Série D: Sciences naturelles 276 (1): 1147-1151. http://gallica.bnf.fr/ ark:/12148/bpt6k5803214k

DEFLANDRE G. 1973d. — Sur quelques nouvelles espèces d'Archocyrtium, radiolaires Pylentonemidae du Viséen de Cabrières. Comptes Rendus hebdomadaires des Séances de l'Académie des Sciences (Paris), Série D: Sciences naturelles 277: 149-152. http://gallica.bnf.fr/ark:/12148/ bpt6k5474901n

Dumitrica P. 1978. - Triassic Palaeoscenidiidae and Entactiniidae from the Vicentinian Alps (Italy) and eastern Carpathians (Romania). Dari de Seama ale Sedintelor, Institutul de Geologie si Geofizica, Bucaresti 64: 39-54.
DUMITRICA P. 1984. - Systematics of Sphaerellarian radiolarian, in Petrushevskaya M. G. \& Stepanjants S. D. (eds), Morphology, ecology and evolution of radiolarians. Material from the IV symposium of European radiolarists EURORAD IV. Akademiya Nauk SSSR, Zoological Institute, Leningrad: 91-102.

DUMITRICA P. 1999. - On the presence of central capsular membranes of Radiolaria in fossil state. Revista Española de Micropaleontología 31 (2): 155-183.

Dumitrica P. 2011. - On the status of the Permian radiolarian genus Multisphaera Nazarov and Afanasieva 2000. Revue de Micropaléontologie 54 (4): 207-213. https://doi.org/10.1016/j. revmic.2011.08.001

Dumitrica P., Kozur H. \& Mostler H. 1980. - Contribution to the radiolarian fauna of the Middle Triassic of the Southern Alps. Geologisch Paläontologische Mitteilungen Innsbruck 10: 1-46.

Dumitrica P., CARIdroit M. \& De Wever P. 2000. — Archaeospicularia, ordre nouveau de radiolaires: une nouvelle étape pour la classification des radiolaires du Paléozoïque inférieur. Comptes Rendus de l'Académie des Sciences Paris, Sciences de la Terre et des planètes 330 (8): 563-569. https://doi.org/10.1016/ S1251-8050(00)00168-3

EHRENBERG C. G. 1843. - Über den Gehalt an unsichtbar kleinen Lebens aus einigen von Hrn. Prof. Koch aus Constantinopel eingesandten Proben der Meeres-Ablagerungen im Marmara-Meer und im Bosporus. Bericht über die zur Bekanntmachung geeigneten Verhandlungen der Königlich Preussischen Akademie der Wissenschaften zu Berlin: 253-257. http://biodiversitylibrary.org/page/11052617

EHRENBERG C. G. 1847. - Über die mikroskopischen kieselschaligen Polycystinen als machtige Gebirgsmasse von Barbados und über das Verhaltniss deraus mehr als 300 neuen Arten bestehenden ganz eigenthumlichen Formengruppe jener Felsmasse zu den jetzt lebenden Thieren und zur Kreidebildung. Eine neue Anregung zur Erforschung des Erdlebens. Bericht über die zur Bekanntmachung geeigneten Verhandlungen der Königliche Preussische Akademie der Wissenschaften zu Berlin 1847: 40-60. http://biodiversitylibrary. org/page/ 11226274

EHRENBERG C. G. 1876. - Fortsetzung der mikrogeologischen Studien als Gesammt-Uebersichtder mikroskopischen Paläontologie gleichartig analysirter Gebirgsarten der Erde, mit specieller Rücksicht auf den Polycystinen-Mergel von Barbados. Abhandlungen der königlichen preussichen Akademie der Wissenschaften zu Berlin 1875: 1-225.

ELICKI O. 2011. - First skeletal microfauna from the Cambrian Series 3 of the Jordan Rift Valley (Middle East). Memoirs of the Association of Australasian Palaeontologists 42: 1-153.

FENG Q. L. 1992. - Permian and Triassic radiolarian biostratigraphy in south and southwest China. Journal of China University of Geosciences 3 (1): 51-62.

FENG Q. L. \& GU S. 2002. - Uppermost Changxingian (Permian) radiolarian fauna from southern Guizhou, southwestern China Journal of Paleontology 76: 797-809. https://doi.org/10.1017/ S0022336000037483

FENG Q. L. \& LiU B. 1992. - A new Early Devonian radiolarian genus from west Yunnan. Science in China, Series D: Earth Sciences 35: 549-553.

FENG Q. L. \& LIU B. 1993a. - A new early Devonian radiolarian genus from western Yunnan. Science in China, Series B: Chemistry 36 (2): 242-248. https://doi.org/10.1360/yb1993-36-2-242

FENG Q. L. \& LiU B. 1993b. - Radiolaria from Late Permian and Early-Middle Triassic in Southwest Yunnan. Earth Science, Journal of China University of Geosciences 18 (5): 540-552.

FENG Q. L., Du Y., ZHANG Z. \& ZENG X. 1994. - Early Triassic radiolarian fauna of Tongbai region in Henan and its geologic significance. Earth Science, Journal of China University of Geosciences 19 (6): 787-794.

FENG Q. L., GU S., JiAng M. \& JIN Y. 2004. — Two new radiolarian genera from the uppermost Permian of southern China. Revue de Micropaléontologie 47 (3): 135-143. https://doi.org/10.1016/ S0035-1598(04)00033-9 
Feng Q. L., He W., Gu S., Jin Y. \& Meng Y. 2006a. — Latest Permian Spumellaria and Entactinaria (Radiolaria) from South China. Revue de Micropaléontologie 49: 21-43. https:// doi.org/10.1016/j.revmic.2005.11.003

Feng Q. L., HE W., Zhang S. \& GU S. 2006b. — Taxonomy of order Latentifistularia (Radiolaria) from the Latest Permian in Southern Guangxi, China. Journal of Paleontology 80 (5): 826848. https://doi.org/10.1666/0022-3360(2006)80[826:TOO $\mathrm{LRF}] 2.0 . \mathrm{CO} ; 2$

Feng Q. L., Meng Y., He W. \& Gu S. 2006c. - A new genus of Entactiniidae (Radiolaria) from the Upper Permian of South China. Eclogae Geologicae Helvetiae 99 (supplement 1): 67-78.

Feng Q. L., GU S., HE W. \& JIN Y. 2007. — Latest Permian Entactinaria (Radiolaria) from southern Guangxi, China. Journal of Micropalaeontology 26 (1): 19-40. https://doi.org/10.1144/ jm.26.1.19

Foreman H. P. 1963. - Upper Devonian Radiolaria from the Huron member of the Ohio shale. Micropaleontology 9 (3): 267 304. https://doi.org/10.2307/1484751

Furutani H. 1983. - Middle Palaeozoic Palaeoscenidiidae (Radiolaria) from Mt. Yokokura, Shikoku, Japan. Part 1. Transactions and Proceedings of the Palaeontological Society of Japan, New Series 130: 96-116.

Furutani H. 1990. — Middle Paleozoic radiolarians from Fukuji Area, Gifu Prefecture, central Japan. Journal of Earth Sciences Nagoya University 37: 1-56.

GoODBODY Q. H. 1986. — Wenlock Palaeoscenidiidae and Entactiniidae (Radiolaria) from the Cape Phillips Formation of the Canadian Arctic Archipelago. Micropaleontology 32 (2): 129-157. https://doi.org/10.2307/1485627

Goto H., Umeda M. \& Ishiga H. 1992. — Late Ordovician Radiolarians from the Lachlan Fold Belt, Southeastern Australia. Memoirs of the Faculty of Science, Shimane University 26: 145-170.

HAECKEL E. 1887. — Report on the Radiolaria collected by H.M.S Challenger during the years 1873-1876. Report on the Scientific Results of the Voyage of the H.M.S. Challenger, Zoology 18: clxxxviii + 1803. https://doi.org/10.5962/bhl.title.6513

HaO \& SHU 1987. — The oldest know well-preserved Phaeodarina (Radiolaria) from southern Shansi. Geosciences (Beijing) 1 (3-4): 301-310.

HENDRIKS E. M. L. 1970. - Facies variations in relation to tectonic evolution in Cornwall. Transactions of the Royal Geological Society of Cornwall 20: 114-151.

HiNDE G. J. 1890. - Notes on Radiolaria from the Lower Palaeozoic rocks (Llandeilo-Caradoc) of the south of Scotland. Annals and Magazine of Natural History 6 (31): 40-59. https://doi. org/10.1080/00222939008693993

HINDE G. J. 1899a. - On the Radiolaria in the Devonian rocks of New South Wales. Quarterly Journal of the Geological Society of London 55: 38-64 https://doi.org/10.1144/GSL.JGS.1899.055.01-04.06

Hinde G. J. 1899b. - On Radiolaria in chert from Chypons Farm, Mullion Parish (Cornwall). Quarterly Journal of the Geological Society of London 55: 214-219. https://doi.org/10.1144/GSL. JGS.1899.055.01-04.14

HoldsworTH B. K. 1966. - Radiolaria and sponges in Namurian "bullion" limestones. Proceedings of the Geological Society of London 1630: 34-35.

HOLDSWORTH B. K. 1969. - Namurian Radiolaria of the genus Ceratoikiscum from Staffordshire and Derbyshire, England. Micropaleontology 15 (2): 221-229. https://doi.org/10.2307/1484921

HOLDSWORTH B. K. 1971. - The ceratoikiscid nature of the radiolarian Lapidopiscum piveteaui Deflandre. Micropaleontology 17 (2): 244-248. https://doi.org/10.2307/1484955

HoldsworTH B. K. 1973. - The Radiolaria of the Baltalimani Formation, lower Carboniferous, Istanbul, Paleozoic of Istanbul. Ege Üniversitesi Fen Fakültesi Kitaplar Serisi (Jeoloji) 40: 117-134.

HoldsworTH B. K. 1977. — Paleozoic Radiolaria: Stratigraphic distribution in Atlantic Borderlands, in SWAIN F. M. (ed.),
Stratigraphic Micropaleontology of Atlantic Basin and Borderlands. Elsevier, Amsterdam, The Netherlands : 167-184. https://doi. org/10.1016/S0920-5446(08)70351-0

Holdsworth B. K. \& Murchey B. L. 1988. — Paleozoic radiolarian biostratigraphy of the northern Brooks Range, Alaska, in GRYC G. (ed.), Geology and Exploration of the National Petroleum Reserve in Alaska, 1974 to 1982. United States Geological Survey, Professional Paper, Report 1399: 777-797.

Holdsworth B. K. \& Jones D. L. 1980. - Preliminary radiolarian zonation for late Devonian through Permian time. Geology 8 (6): 281-285. https://doi.org/10.1130/00917613(1980)8<281:PRZFLD>2.0.CO;2

Holdsworth B. K., Jones D. L. \& Allison C. W. 1978. Upper Devonian radiolarians separated from chert of the Ford Lake Shale, Alaska. Journal of Research of the U.S. Geological Survey 6: 775-788.

IsaKova T. N. \& NAZAROv B. B. 1986. — Late Carboniferous-Early Permian stratigraphy and microfauna of the Southern Urals. Doklady Akademii Nauk SSSR 402: 1-183, 32 pls.

IsHigA H. 1982. — Late Carboniferous and Early Permian radiolarians from the Tamba Belt, Southwest Japan. Earth Science, Journal of the Association for the Geological Collaboration in Japan 36 (6): 333-339.

Ishiga H. \& IMOTO N. 1980. - Some Permian radiolarians in the Tamba District, Southwest Japan. Earth Science, Journal of the Association for the Geological Collaboration in Japan 34 (6): 333-345.

Ishiga H., Kiтo T. \& Iмото N. 1982a. — Late Permian radiolarian assemblages in the Tamba District and an adjacent area, Southwest Japan. Earth Science, Journal of the Association for the Geological Collaboration in Japan 36 (1): 10-22.

Ishiga H., Kito T. \& Imoto N. 1982b. - Middle Permian radiolarian assemblages in the Tamba district and adjacent area, Southwest Japan. Earth Science, Journal of the Association for the Geological Collaboration in Japan 36 (1): 272-281.

Ishiga H., Leitch E. C., NAKA T., Watanabe T. \& IWASAKI M. 1987. — Late Devonian Palaeoscenidiidae from the Hastings Block, New England Fold Belt, N.S.W., Australia. Earth Science (Chikyu Kagaku) 41 (6): 297-302. https://doi.org/10.15080/ agcjchikyukagaku.41.6_297

JoNeS M. K. \& Noble P. J. 2006. — Sheinwoodian (uppermost Lower Silurian) Radiolaria from the Cape Phillips Formation, Nunavut, Canada. Micropaleontology 52: 289-315. https://doi. org/10.2113/gsmicropal.52.4.289

KozUR H. W. 1980. — Ruzhencevispongidae, eine neue Spumellaria Familie ausdemoberen Kungurian (Leonardian) und Sakmarian des Vorurals. Geologisch Paläontologische Mitteilungen Innsbruck 10 (6): 235-242.

Kozur H. W. 1981. — Albaillellidea (Radiolaria) aus dem Unterperm des Vorurals. Geologisch Paläontologische Mitteilungen Innsbruck 10 (8): 263-274.

KozUR H. W. 1993. - Upper Permian Radiolarians from the Sosio Valley Area, Western Sicily (Italy) and from the Uppermost Lamar Limestone of West Texas. Jahrbuch der geologischen Bundesanstalt 136 (1): 99-123.

Kozur H. W. \& Mostler H. 1972. — Beiträge zur Erforschung der mesozoischen Radiolarien. Teil I: Revision der Oberfamilie Coccodiscacea HAECKEL 1862 emend, und Beschreibung ihrer triassischen Vertreter. Geologisch Paläontologische Mitteilungen Innsbruck 2: 1-60.

Kozur H. W. \& Mostler H. 1978. — Beiträge zur Erforschung der mesozoischen Radiolarien Teil II: Oberfamilie Trematodiscacea HAECKEL 1862 emend, und Beschreibung ihrer triassischen Vertreter. Geologisch Paläontologische Mitteilungen Innsbruck 8: 123-182.

Kozur H. W. \& Mostler H. 1979. — Beiträge zur Erforschung der mesozoischen Radiolarien. Teil III: Die Oberfamilien Actinommacea HAECKEL 1862 emend., Artiscacea HAECKEL1882, Multiarcusellacea nov. der Spumellaria und triassische Nassellaria. Geologisch Paläontologische Mitteilungen Innsbruck 9 (1/2): 1-132. 
Kozur H. W. \& Mostler H. 1981. — Beiträge zur Erforschung der mesozoischen Radiolarien. Teil IV: Thalassosphaeracea HAECKEL 1862, Hexastylacea HAECKEL 1862 emend. PETRUŠEVSKAJA 1979, Sponguracea HAECKEL 1862 emend. und weitere triassische Lithocycliacea, Trematodiscacea, Actinommacea und Nassellaria. Geologisch Paläontologische Mitteilungen Innsbruck, Sonderband 1: 1-208.

Kozur H. W. \& Mostler H. 1982. — Entactinaria subordo nov., a new radiolarian suborder. Geologisch Paläontologische Mitteilungen Innsbruck 11 (1): 399-414.

Kozur H. W. \& Mostler H. 1989. — Radiolarien und schwammskleren aus dem Unterperm des Vorurals. Geologisch Paläontologische Mitteilungen Innsbruck, Sonderband 2: 147-275.

Kozur H. W. \& Mostler H. 1994. — Anisian to middle Carnian radiolarian zonation and description of some stratigraphically important radiolarians. Geologisch Paläontologische Mitteilungen Innsbruck, Sonderband 3: 39-255.

KozUR H. W. \& REPETSKI J. E. 2002. — Paulanoblella, nomen novum (Radiolaria) replaces Noblella Kozur, Mostler and Repetski 1996 , a homonym of Noblella Barbour 1930 (Amphibia). Journal of Micropalaeontology 21 (1): 28. https://doi.org/10.1144/jm.21.1.28

Kozur H. W., Mostler H. \& Repetski J. E. 1996. - Wellpreserved Tremadocian primitive Radiolaria from the Windfall Formation of the Antelope Range, Eureka County, Nevada, U.S.A. Geologisch Paläontologische Mitteilungen Innsbruck 21: 245-271.

Li H. 1991. - First discovery of middle Silurian Radiolaria fossils in Xinjiang. Scientia Geologica Sinica 1991: 75.

Li H. S. 1994. - Middle Silurian radiolarians from Keerhada, Xinjiang. Acta Micropalaeontologica Sinica 11: 259-272.

LI H. S. 1995. - New genera and species of middle Ordovician Nassellaria and Albaillellaria from Baijingsi, Quilian Mountains, China. Scientia Geologica Sinica 4 (3): 331-346.

LI Y. X. \& WANG Y. J. 1991. — Upper Devonian (Frasnian) radiolarian fauna from the Liukiang Formation, eastern and southeastern Guangxi. Acta Micropalaeontologica Sinica 8 (4): 395-404.

LIU 1992. - Fossil radiolarians from the turbidite of the Middle Carboniferous east Tianshan Mountain, Xinjiang. Journal of Northwest University, Natural Science Education 22: 123-130, 169-170.

Loeblich A. R. \& TAPPAN H. 1961. - Remarks on the systematics of the Sarkodina (Protozoa), renamed homonyms and new validated genera. Proceedings of the Biological Society of Washington 74: 213-234. http://biodiversitylibrary.org/page/34571345

MacDonald E. W. 1998. - Llandovery Secuicollactinae and Rotasphaeridae (Radiolaria) from the Cape Phillips Formation, Cornwallis Island, Arctic Canada. Journal of Paleontology 72: 585-604. https://doi.org/10.1017/S0022336000040324

MacDonald E. W. 1999. - Insolitignum n.gen. and Palaeoephippium Goodbody 1986 (Radiolaria) from the Lower Silurian of the Cape Phillips Formation, Arctic Canada. Canadian Journal of Earth Science 36 (12): 2051-2057. https://doi.org/10.1139/ e99-101

MacDonald E. W. 2003. - Radiolaria from the Lower Silurian of the Cape Phillips Formation, Cornwallis Island, Nunavut, Canada. Dalhousie University, Halifax, NS, Canada, 370 p.

MaCDONALD E. W. 2004. - Palaeoscenidiidae (Radiolaria) from the Lower Silurian of the Cape Phillips Formation, Cornwallis Island, Nunavut, Canada. Journal of Paleontology 78 (2): 257 274. https://doi.org/10.1666/0022-3360(2004)078<0257:PRF TLS>2.0.CO;2

MacDonald E. W. 2006a. - Haplotaeniatumidae and Inaniguttidae (Radiolaria) from the Lower Silurian of the Cape Phillips Formation, Cornwallis Island, Nunavut, Canada. Journal of Paleontology 80: 19-37. https://doi.org/10.1666/00223360(2006)080[0019:HAIRFT]2.0.CO;2

MACDONALD E. W. 2006b. - A preliminary radiolarian biozonation for the Lower Silurian of the Cape Phillips Formation, Nunavut, Canada. Canadian Journal of Earth Sciences 43: 205-211. https:// doi.org/10.1139/e05-104
Maldonado A. L. \& Noble P. J. 2010. - Radiolarians from the upper Guadalupian (Middle Permian) ReefTrail Member of the Bell Canyon Formation, West Texas and their biostratigraphic implications. Micropaleontology 56: 69-115.

MALETZ J. 2011a. - Radiolarian skeletal structures and biostratigraphy in the early Palaeozoic (Cambrian-Ordovician). Palaeoworld 20: 116-133. https://doi.org/10.1016/j.palwor.2010.12.007

Maletz J. 2011b. - Tetrentactinia barysphaera Foreman 1963: skeletal structure and age of a biostratigraphically important Famennian (Upper Devonian) radiolarian from the Ohio Shale, USA. Paläontologische Zeitschrift 85 (4):383-392. https://10.1007/ s12542-011-0103-3

Maletz J. \& Bruton D. L. 2005. - The Beothuka terranova (Radiolaria) assemblage and its importance for the understanding of early Ordovician radiolarian evolution. Geological Magazine 142: 711-721. https://doi.org/10.1017/S0016756805001391

Maletz J. \& BRUTON D. L. 2007. - Lower Ordovician (Chewtonian to Castlemainian) radiolarians of Spitsbergen. Journal of Systematic Palaeontology 5: 245-288. https://doi.org/10.1017/ S1477201907002039

Maksimova Z. A. 1978. - Some new Devonian trilobites. Ezhegodnik Vsesoyuznogo Paleontologicheskogo Obshchestva 21: 94-109.

Mostler H. \& Mosleh-Yazdi A. 1976. - Neue Poriferen aus oberkambrischen Gesteinen der Milaformation im Elbruzgebirge (Iran). Geologisch Paläontologische Mitteilungen Innsbruck 5: 1-36.

NAZAROV B. B. 1973. - Radiolarians from the Lower Cambrian of the Batenev Ridge, in Zhuravleva I. I. (ed.), Problems of paleontology and biostratigraphy of the Lower Cambrian of Siberia and Russian Far East. Transactions of the Institute of Geology and Geophysics, Academy of Sciences of the USSR Siberian Branch 49: 5-13.

NaZAROV B. B. 1974. - Problematic Siliceous Formations from the Lower Paleozoic of Kazakhstan, in ZHURAVLEVA I. T. \& Rozanov A. Y. (eds), Biostratigraphy and Paleoecology of the Lower Cambrian of Europe and Northern Asia. Nauka, Moscow: 110-112.

NAZAROV B. B. 1975a. - On the systematics of Paleozoic Sphaeroids, in ZHAMOIDA A. I. (ed.), Systematics and Stratigraphic Importance of Radiolaria. Publication of the All-Union Institute of Geology, new series, Leningrad, USSR: 35-40.

NazArov B. B. 1975b. - Lower and Middle Paleozoic radiolarians of Kazakhstan (research methods, systematics, stratigraphic importance). Transactions of the Academy of Sciences of the USSR, Geological Institute 275: 1-203 p.

NAZAROV B. B. 1977. - A new radiolarian family from the Ordovician of Kazakhstan. Paleontological Journal 11 (2): 165-171.

NazArov B. B. 1981. - Evolution of Radiolaria in the Paleozoic and questions of their systematics, in KRASHENINNIKOV V. A. (ed.), Systematics, Evolution and Stratigraphic Significance of Radiolaria. Nauka, Moscow: 22-37.

NazArov B. B. 1988. - Paleozoic radiolaria, Practical manual of microfauna of the USSR. Nedra, Leningrad. Radiolyarii Paleozoy 2: 1-232.

NAZAROV B. B. \& POPOV L. Y. 1976. - Radiolarians, ecardine brachiopods and organisms of uncertain systematic position from the Middle Ordovician of eastern Kazakhstan. Paleontological Journal 4: 407-416.

NAZAROV B. B. \& POPOV L. Y. 1980. - Stratigraphy and fauna of the siliceous-carbonate sequence of the Ordovician of Kazakhstan (Radiolaria and inarticulate brachiopods). Transactions of the Geological Institute of the Soviet Akademy of Sciences 331: 1-192.

NazARov B. B. \& Ormiston A. 1983a. - Upper Devonian (Frasnian) radiolarian fauna from the Gogo Formation, Western Australia. Micropaleontology 29 (4): 454-466. https://doi. org/10.2307/1485519

NazARov B. B. \& Ormiston A. 1983b. - A new superfamily of stauraxon polycystine Radiolaria from the Late Paleozoic of the Soviet Union and North America. Senckenbergiana Lethaea 64: 363-379. 
Nazarov B. B. \& Ormiston A. 1984. - Tentative system of Paleozoic Radiolaria, in Petrushevskaya M. G. \& StePANJANTS S. D. (eds), Morphology, Ecology and Evolution of Radiolarians. Material from the IV Symposium of European Radiolarists EURO$R A D I V$. Academiya Nauk SSSR, Zoological Institute, Leningrad, USSR: 64-87.

Nazarov B. B. \& Ormiston A. R. 1985. - Radiolaria from the Late Paleozoic of the Southern Urals, USSR and West Texas, USA. Micropaleontology 31 (1): 1-54. https://doi.org/10.2307/1485579

NAZAROV B. B. \& OrMiston A. R. 1986. - Origin and biostratigraphic potential of the stauraxon polycystine Radiolaria. Marine Micropaleontology 11: 33-54. https://doi.org/10.1016/03778398(86)90004-6.

Nazarov B. B. \& Ormiston A. R. 1987. - A new Carboniferous radiolarian genus and its relation to the multishelled entactiniids. Micropaleontology 33 (1): 66-73. https://doi.org/10.2307/1485527

Nazarov B. B. \& Ormiston A. R. 1990. - The biostratigraphic potential of radiolarians from the Palaeozoic, in CHUVASHOV B. I., Zhamoida A. I. \& Amon E. O. (eds), Radiolaria in Biostratigraphy: Collected Proceedings. Ural'skoe otdelenie AN SSSR; Sverdlovsk: 3-25, 121, 125, 126

NAZAROV B. B. \& ORMISTON A. R. 1993. - New biostratigraphically important Paleozoic Radiolaria of Eurasia and North America, in BluEFord J. R. \& MURCHEY B. L. (eds), Radiolaria of Giant and Subgiant Fields in Asia. Nazarov Memorial Volume. Micropaleontology, Special Publication 6: 22-60.

NAZAROV B. B., Popov L. \& Apollonov M. 1975. — Radiolyarii nizhnego paleozoya Kazakhstana (Lower Paleozoic Radiolaria in Kazakhstan). Izvestiya Akademiya Nauk SSSR, Seriya Geologicheskaya (Proceedings of the USSR Academy of Sciences, Geological Series) 10: 96-105.

Nazarov B. B. \& Rudenko V. S. 1981. - Some radiolarians with bilateral symmetry of the upper Paleozoic of the Southern Urals. Systematics and Morphology of Microorganisms: Problems of Micropaleontology 24: 129-139.

NaZAROV B. B., TKaCHENKO V. I. \& SHUlgina V. S. 1981. — Radiolaria and age of terrigenous siliceous beds of the Kolyma region. Izvestija Akademii Nauk SSSR, serija geologičeskaja 10: 79-89.

Nestell G. P. \& Nestell M. K. 2010. — Late Capitanian (latest Guadalupian, Middle Permian) radiolarians from the Apache Mountains, West Texas. Micropaleontology 56 (1-2): 7-68. https:// www.jstor.org/stable/40607076

Noble P. J. 1994. - Silurian Radiolarian Zonation for the Caballos Novaculite, Marathon Uplift, West Texas. Bulletins of American Paleontology 106 (2): 1-55. http://biodiversitylibrary.org/ page/10684913

NobLE P. J. 2014. - Maletzella nomen novum, a replacement name for the junior homonym Franklinia Jones and Noble 2006. Revue de Micropaléontologie 57: 35. https://doi.org/10.1016/j. revmic.2014.01.001

Noble P. J. \& JiN Y. 2010. — Radiolarians from the Lamar Limestone, Guadalupe Mountains, West Texas. Micropaleontology 56 (1-2): 117-147. https://www.jstor.org/stable/40607078

Noble P. J. \& Lenz A. C. 2007. - Upper Wenlock Ceratoikiscidae (Radiolaria) from the Cape Phillips Formation, Arctic Canada. Journal of Paleontology 81 (5): 1044-1052. https://doi. org/10.1666/pleo05-053.1

Noble P. J. \& MALETZ J. 2000. - Radiolaria from the Telychian (Llandovery, Early Silurian) of Dalarna, Sweden. Micropaleontology 46: 265-275. https://doi.org/10.2113/46.3.265

Noble P. \& RenNe P. 1990. - Paleoenvironmental and biostratigraphic significance of siliceous microfossils of the Permo-Triassic Redding Section, Eastern Klamath Mountains, California. Marine Micropaleontology 15 (3-4):379-391. https://doi.org/10.1016/0377-8398(90)90021-D

Noble P. J. \& WebBy B. D. 2009. - Katian (Ordovician) radiolarians from the Malongulli Formation, New South Wales, Australia, a reexamination. Journal of Paleontology 83: 548-561. https://doi. org/10.1666/08-179R.1
Noble P. J., Braun A. \& Mc Clellan W. 1998. - Haplotaeniatum faunas (Radiolaria) from the Llandoverian (Silurian) of Nevada and Germany. Neues Jahrbuch für Geologie und Paläontologie, Monatshefte 12: 705-726.

Noble P. J., Tekin U. K., Gedik I. \& Pehlivan S. 2008. — Middle to Upper Tournaisian Radiolaria of the Baltalimani Formation, Istanbul, Turkey. Journal of Paleontology 82 (1): 37-56. https:// doi.org/10.1666/06-046.1

O'Dogherty L., Carter E. S., Dumitrica P., Gorican S. \& De WeVER P. 2009. - An illustrated and revised catalogue of Mesozoic radiolarian genera; objectives, concepts and guide for users. Geodiversitas 31: 191-212. https://doi.org/10.5252/g2009n2a2

Oвut O. T. \& IwATA K. 2000. — Lower Cambrian Radiolaria from the Gorny Altai (southern West Siberia). Novosti Paleontologii i Stratigrafii 2-3: 33-37.

Obut O. T. \& Shcherbanenko T. A. 2008. - Late Devonian radiolarians from the Rudny Altai (SW Siberia). Bulletin of Geosciences 83 (4): 371-382. https://doi.org/10.3140/bull.geosci.2008.04.371

Ormiston A. R. \& LANE H. R. 1976. - A unique radiolarian fauna from the Sycamore Limestone (Mississippian) and its biostratigraphic significance. Palaeontographica. Abteilung A: Paleozoologie-Stratigraphie 154: 158-180.

Ormiston A. R. \& BABCOCK L. 1979. - Follicucullus, new radiolarian genus from the Guadalupian (Permian) Lamar limestone of the Delaware Basin. Journal of Paleontology 53 (2): 328-334. http://www.jstor.org/stable/1303874

Oudemans A. C. 1936. - Kritisch Historisch Overzicht der Acarologie. IIIA. World-wide E. J. Brill, Leiden, 430 p.

ÖZDIKMEN H. 2009. - Substitute names for some unicellular animal taxa (Protozoa). Munis Entomology and Zoology 4 (1): 233-256.

PARK I.-Y. \& WON M.-Z. 2012. — Tropical radiolarian assemblages from the Lower Carboniferous Delle Phosphatic Member of the Woodman Formation of Utah, USA. Journal of the Paleontological Society of Korea 28 (1-2): 29-101.

Pessagno E. A., JR., Six W. M. \& YAng Q. 1989. — The Xiphostylidae Haeckel and Parvivaccidae, n. fam, (Radiolaria) from the North American Jurassic. Micropaleontology 35 (3):193-255. https://doi.org/10.2307/1485682

ReNZ G. W. 1990. — Late Ordovician (Caradocian) radiolarians from Nevada. Micropaleontology 36 (4): 367-377. https://doi org $/ 10.2307 / 1485476$

RIEDEL W. R. 1967. — Some new families of Radiolaria. Proceedings of the Geological Society of London 1640: 148-149.

RÜST D. 1892. - Beiträge zur Kenntnis der fossilen Radiolarien aus Gesteinen der Trias und der palaeozoischen Schichten. Palaeontographica 38: 107-192, 30 pls.

SASHIDA K. \& TONISHI K. 1985. - Permian radiolarians from the Kanto Mountains, central Japan; some Upper Permian Spumellaria from Itsukaichi, western part of Tokyo Prefecture. Science Reports of the Institute of Geoscience, University of Tsukuba, Section B: Geological Sciences 6: 1-19.

SASHIDA K. \& TONISHI K. 1988. - Additional note on the Upper Permian radiolarian fauna from Itsukaichi, western part of Tokyo Prefecture, central Japan. Transactions and Proceedings of the Palaeontological Society of Japan, New Series 151: 523-542. https:// doi.org/10.14825/prpsj1951.1988.151_523

SASHida K. \& TONISHI K. 1991. - An Upper Permian coiled radiolarian from Itsukaichi, central Japan. Micropaleontology 37 (1): 86-94. https://doi.org/10.2307/1485747

SASHIDA K., ADACHI S., IgO H., NAKORNSKI N. \& AMPORNMAHA A. 1997. - Middle to Upper Permian and Middle Triassic radiolarians from Eastern Thailand. Science Reports of the Institute of Geoscience, University of Tsukuba, section B: Geological Sciences 18: 1-17.

Sashida K., SalyapongSe S. \& Nakornsri N. 2000. — Latest Permian radiolarian fauna from Klaeng, eastern Thailand. Micropaleontology 46: 245-263. https://doi.org/10.2113/46.3.245 
SChWARTZAPFel J. A. \& Holdsworth B. K. 1996. - Upper Devonian and Mississippian radiolarian zonation and biostratigraphy of the Woodford, Sycamore, Caney and Goddard Formations, Oklahoma. Cushman Foundation for Foraminiferal Research, Special Publication 33: 1-275.

SEO E.-H. \& Won M.-Z. 2009. - Review of the genus Polyentactinia and the family Polyentactiniidae. Micropaleontology 55 (1): 61-74. http://www.jstor.org/stable/20627972

SHENG J. Z. \& WANG Y. J. 1985. — Fossil Radiolaria from Kufeng Formation at Longtan, Nanjing. Acta Palaeontologica Sinica 24 (2): $171-183$.

SugrYama K. 2000. - Replacement names for Permian stauraxon radiolarians. Paleontological Research 4 (3): 227, 228. https://doi. org/10.2517/prpsj. 4.227

TAKEMURA A. \& NAKASEKO K. 1981. - A new Permian radiolarian genus from the Tamba Belt, Southwest Japan. Transactions and Proceedings of the Palaeontological Society of Japan, New Series 124: 208-214. https://doi.org/10.14825/prpsj1951.1981.124_208

TaKemura A., Morimoto T., Aita Y., Hori R. S., Higuchi Y., SPÖrLi K. B., Campbell H. J., Kodama K. \& SaKai T. 1999. — Permian Albaillellaria (Radiolaria) from a limestone lens at the Arrow Rocks in the Waipapa Terrane (Northland, New Zealand). Geodiversitas 21 (4): 751-765.

Ters M. \& Deflandre G. 1966. — Sur l'âge cambro-silurien des terrains anciens de la Vendée littorale (ex-Briovérien). Comptes Rendus hebdomadaires des Séances de l'Académie des Sciences (Paris), Série D: Sciences naturelles 262 (3): 339-342. http://gallica.bnf.fr/ ark:/12148/bpt6k5489696x

Tetard M., Danelian T. \& Noble P. 2014. - Biostratigraphical and palaeobiogeographical implications of Lower Silurian Radiolaria from black cherts of the Armorican Massif (France). Journal of Micropalaeontology 33: 165-178. https://doi.org/10.1144/jmpaleo2014-013

Tetard M., Noble P. J., Danelian T., Monnet C. \& Lenz A. C. 2015. - A new Gorstian radiolarian fauna from the upper Silurian of the Cape Phillips Formation, Cornwallis and Bathurst islands, Canadian Arctic. Canadian Journal of Earth Sciences 52 (10): 863879. https://doi.org/10.1139/cjes-2015-0028

UMEDA M. 1998. - Early to Middle Devonian Ceratoikiscidae (Radiolaria) from the Yokokurayama Group in the Kurosegawa Terrane, Southwest Japan. Paleontological Research 2 (2): 96-107. https://doi.org/10.2517/prpsj.2.96

WaKamatsu H., Sugiyama K. \& Furutani H. 1990. — Silurian and Devonian radiolarians from the Kurosegawa Tectonic Zone, southwest Japan. Journal of Earth Sciences, Nagoya University 37: 157-192.

WANG R. 1995. - Radiolarian fauna from Gufeng Formation (Lower Permian) in Hushan area of Nanjing, Jiangsu province. Scientia Geologica Sinica 30 (2): 139-148.

WANG Y. J. 1997. — An Upper Devonian (Famennian) radiolarian fauna from carbonate rocks, northern Xinjiang. Acta Micropalaeontologica Sinica 14 (2): 149-160.

WANG Y. J. \& KUANG 1993. - Early Carboniferous radiolarians from Qinzhou, southeastern Guangxi. Acta Micropalaeontologica Sinica 10 (2): 275-287.

Wang Y. J. \& Shang Q. 2001. - Discovery of the Neoalbaillella radiolarian fauna in the Shaiwa Group of Ziyun District, Guizhou. Acta Micropalaeontologica Sinica 18 (2): 111-121.

WANG Y. J., AITCHISON J. C. \& LUO H. 2003. — Devonian radiolarian faunas from south China. Micropaleontology 49 (2): 127-145. https://doi.org/10.2113/49.2.127

WANG Y. J., ChEnG J. F. \& Zhang Y. D. 2008. — New radiolarian genera and species of Heituao Formation (Ordovician) in the Kuruktag Region, Xinjiang. Acta Palaeontologica Sinica 47: 393-404.

WANG Y. J., ChEnG J. F. \& ZHANG Y. D. 2010. — Fossil preservation modes and functional discussion of the basic structures of a new radiolarian genus Gansuceratoikiscum Wang gen. nov. Acta Palaeontologica Sinica 49 (4): 472-476.

WebBy B. D. \& Blom W. 1986. — The first well-preserved radiolarians from the Ordovician of Australia. Journal of Paleontology 60:
145-157. https://doi.org/10.1017/S0022336000021594

Won M. Z. 1983. - Radiolarien aus dem Unterkarbon des Rheinischen Schiefergebirges (Deutschland). Palaeontographica. Abteilung A: Palaozoologie-Stratigraphie 182: 116-175.

Won M. Z. 1991. — Lower Carboniferous radiolarians from siliceous boulders in Western Germany. Journal of the Paleontological Society of Korea 7 (2): 77-106.

Won M. Z. 1997a. — Review of family Entactiniidae (Radiolaria), and taxonomy and morphology of Entactiniidae in the late Devonian (Frasnian) Gogo Formation, Australia. Micropaleontology 43 (4): 333-369. https://doi.org/10.2307/1485930

Won M.Z. 1997b. - The proposed new radiolarian subfamily Retentactiniinae (Entactiniidae) from the late Devonian (Frasnian) Gogo Formation, Australia. Micropaleontology 43 (4): 371-418. https:// doi.org/10.2307/1485931

Won M. Z. 1998. - A Tournaisian (Lower Carboniferous) radiolarian zonation and radiolarians of the $A$. pseudoparadoxa Zone from Oese (Reinische Schiefergebirge), Germany. Journal of Korean Earth Science Society 19 (2): 216-259.

Won M. Z. \& Below R. 1999. - Cambrian Radiolaria from the Georgina Basin, Queensland, Australia. Micropaleontology 45: 325363. https://doi.org/10.2307/1486119

WON M. Z. \& IAMS W. J. 2002. — Late Cambrian radiolarian faunas and biostratigraphy of the Cow Head Group, western Newfoundland. Journal of Paleontology 76 (1): 1-33. https://doi.org/10.1017/ S0022336000017315

WON M. Z. \& SEO E. H. 2010. — Lower Carboniferous radiolarian biozones and faunas from Bergishes Land, Germany. Journal of the Paleontological Society of Korea 26 (2): 193-269.

Won M. Z. \& IAMs W. J. 2011. — Earliest Arenig Radiolarians from the Cow Head Group, Western Newfoundland. Journal of Paleontology 85 (1): 156-177. https://doi.org/10.1666/10-102.1

WON M.-Z. \& IAMS W. J. 2013. — Early Ordovician (early Arenig) radiolarians from the Cow Head Group and review of the Little Port Complex fauna, Western Newfoundland. Palaeoworld 22 (1-2) 10-31. https://doi.org/10.1016/j.palwor.2012.11.001

WON M. Z. \& IAMS W. J. 2015. — Early/Middle Arenig (Late Floian) Radiolarian Faunal Assemblages from Cow Head Group, Western Newfoundland. Palaeontographica Abteilung A: 1-63.

Won M. Z., Blodgett R. B. \& Nestor V. 2002. - Llandoverian (Early Silurian) radiolarians from the Road River Formation of East-Central Alaska and the new family Haplotaeniatumidae. Journal of Paleontology 76:941-964. https://doi.org/10.1017/ S0022336000057796

Won M. Z., IAMS W.J \& REED K. 2005. — Earliest Ordovician (Early to Middle Tremadocian) radiolarian faunas of the Cow Head Group Western Newfoundland. Journal of Paleontology 79 (3): 433-459. https://doi.org/10.1666/0022-3360(2005)079<0433:EOETM $\mathrm{T}>2.0 . \mathrm{CO} ; 2$

Won M. Z., IAMS W. J. \& ReED K. 2007a. — Late Tremadocian Radiolarian Faunas and Biostratigraphy of the Cow Head Group, Western Newfoundland, Canada. Journal of the Korean Earth Science Society 28 (4): 497-540. https://doi.org/10.5467/JKESS.2007.28.4.497

Won M.Z., IAMS W. J., REED K. \& BELOw R. 2007b. — Review of Family Anakrusidae and its relationship to Kometia (Porifera: Hexactinellidae). Journal of the Paleontological Society of Korea 23 (1): 73-91.

Wu J., Feng Q., GuI B. \& LiU G. 2010. — Some New Radiolarian Species and Genus from Upper Permian in Guangxi Province, South China. Journal of Paleontology 84 (5): 879-894. https://doi. org/10.1666/09-057.1

ZHANG X. G. \& ALDRIDGE R. J. 2007. - Development and diversification of trunk plates of the lower Cambrian lobopodians. Palaeontology 50: 401-415. https://doi.org/10.1111/j.1475-4983.2006.00634.x

Submitted on 21st September 2016; accepted on 11 July 2017; published on 29 September 2017. 